This report was prepared as an account of work sponsored by an agency of the United States Government. Neither the United States Government nor any agency thereof, nor any of their employees, makes any warranty, express or implied, or assumes any legal liability or responsibility for the accuracy, completeness, or usefulness of any information, apparatus, product, or process disclosed, or represents that its use would not infringe privately owned rights. Reference herein to any specific commercial product, process, or service by trade name, trademark, manufacturer, or otherwise does not necessarily constitute or imply its endorsement, recommendation, or favoring by the United States Government or any agency thereof. The views and opinions of authors expressed herein do not necessarily state or reflect those of the United States Government or any agency thereof.

\title{
Corrosion Investigation of Multilayered Ceramics and Experimental Nickel Alloys in SCWO Process Environments
}

\author{
Karen M. Garcia \\ Ron Mizia
}

Published February 1995

\section{Idaho National Engineering Laboratory Lockheed Idaho Technologies Company Idaho Falls, Idaho 83415}

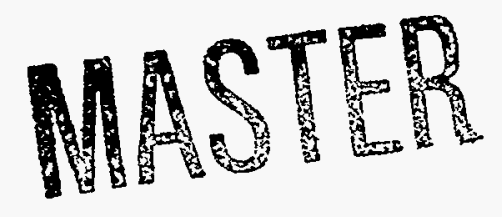

Prepared for the

U.S. Department of Energy

Assistant Secretary for Environmental Management

Under DOE Idaho Operations Office

Contract DE-AC07-94ID13223 


\section{Corrosion Investigation of Multilayered Ceramics and Experimental Nickel Alloys in SCWO Process Environments}

INEL-94/0017

Prepared by

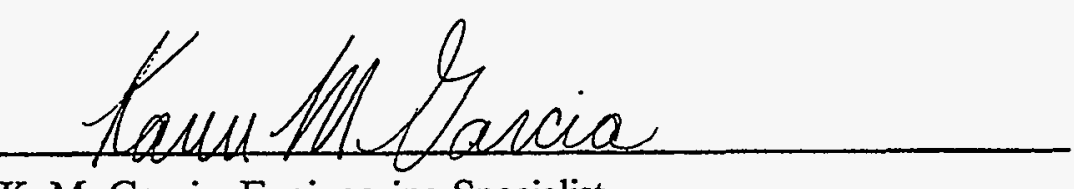

K. M. Garcia, Engineering Specialist

Mechanical Engineering

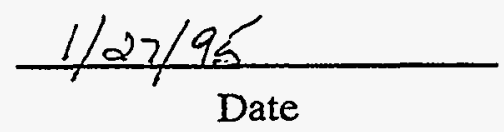

Date

Reviewed by

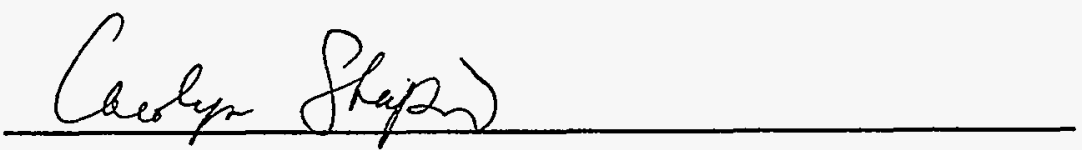

C. Shapiro, Engineering Specialist

Mechanical Engineering

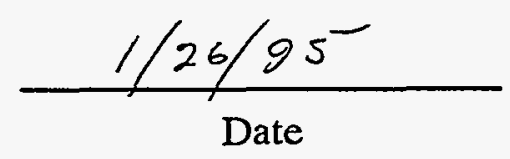

Approved by

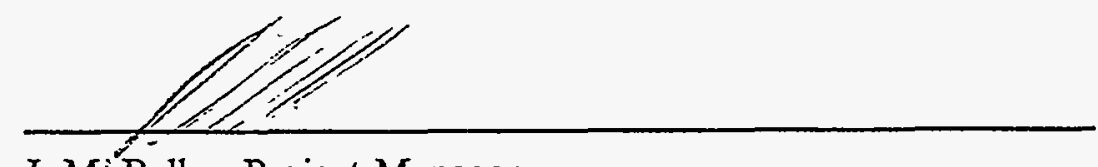

J. M. Beller, Project Manager

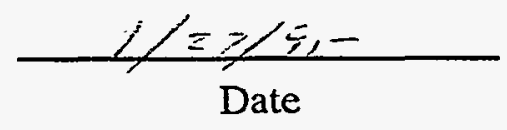

Waste Technology Development 


\section{DISCLAIMER}

Portions of this document may be illegible in electronic image products. Images are produced from the best available original document. 


\begin{abstract}
A corrosion investigation was done at MODAR, Inc., using a supercritical water oxidation (SCWO) vessel reactor. Several types of multilayered ceramic rings and experimental nickel alloy coupons were exposed to a chlorinated cutting oil, TrimSol, in the SCWO process. A corrosion casing was designed and mounted in the vessel reactor with precautions to minimize chances of degrading the integrity of the pressure vessel. Fifteen of the ceramic coated rings were stacked vertically in the casing at one time for each test. There was a total of 36 rings. The rings were in groupings of three rings that formed five sections. Each section saw a different SCWO environment, ranging from $650^{\circ} \mathrm{C}$ to $300^{\circ} \mathrm{C}$. The metal coupons were mounted on horizontal threaded holders welded to a vertical rod attached to the casing cover in order to hang down the middle of the casing. The experimental nickel alloys performed better than the baseline nickel alloys. A titania multilayered ceramic system sprayed onto a titanium ring remained intact after 120-180 hours of exposure. This is the longest time any coating system has withstood such an environment without significant loss.
\end{abstract}





\section{SUMMARY}

A goal of the Department of Energy (DOE) is to develop the supercritical water oxidation (SCWO) process for the treatment of some of its mixed waste inventories. In support of the SCWO design process, material systems capable of withstanding the harsh SCWO environment are being investigated. Three corrosion tests were run using the MODAR, Inc., SCWO vessel reactor to treat the chlorinated cutting oil TrimSol combined with surrogates of cerium chloride, zinc chloride, and lead chloride. The goal of the test was to expose the stack of ceramic rings and metal coupons to the five SCWO environments in order to compare their performance. The TrimSol was pumped at $3,400 \mathrm{psi}$ and $40 \mathrm{~mL} / \mathrm{min}$. It was mixed with the water and metals stream that had a flow rate of $80 \mathrm{~mL} / \mathrm{min}$. This was brought into the reactor and mixed with $350 \mathrm{~L} / \mathrm{min}$ air and $300 \mathrm{~mL} / \mathrm{min}$ of water heated up to $400^{\circ} \mathrm{C}$. A corrosion casing was designed and mounted in the vessel reactor in a manner that minimized chances of degrading the integrity of the pressure vessel. Fifteen of the 36 ceramic coated rings were stacked vertically in the casing at one time for each test. The rings were metal with multiple layers of ceramic coatings sprayed onto the inside of the rings. Each ring was 3 in. in height and 7 in. in dianeter. The rings were cemented together inside of the casing. There were five groupings of three rings. Additionally, metal coupons were mounted on horizontal thread holders welded to a vertical rod attached to the casing cover in order to hang down the middle of the casing. The length of the casing traversed five different temperature zones ranging from $650^{\circ} \mathrm{C}$ to $300^{\circ} \mathrm{C}$. After the reaction zone a quench stream diluted the process effluent from about $8,000 \mathrm{ppm}$ of chloride concentration down to $5,000 \mathrm{ppm}$ chloride concentration. The stream was not neutralized until it entered the cooldown zone near the bottom ring, near the last two coupon holders, just before it exited the casing through an exit pipe at the bottom of the casing. The processed waste stream produced hydrochloric acid, sulfuric acid, and salts during the SCWO reaction. The greatest interest was in the performance of the materials in the high temperature sections, and the transition section from supercritical to subcritical, approximately 400 to $350^{\circ} \mathrm{C}$.

The performance of the multilayered ceramics and experimental nickels was evaluated by comparison against the baseline nickel alloys C-22, C-276, Inconel 625, and Inconel 686. Three tests were run. The first test was for 60 hours with five temperature cycles. The second was for 60 hours with just two temperature cycles. The third was for 120 hours with just two temperature cycles. It was anticipated that the temperature cycles would show if the ceramics tended toward delamination during startups or cooldown. For each temperature cycle the casing was allowed to drop to below $300^{\circ} \mathrm{C}$. After the first 60 -hour test the top three and bottom three rings would be removed and analyzed while three new rings were put into the top and bottom sections for the second 60-hour test. After the second 60-hour test the top and bottom six rings would be removed and replaced, and then the 120-hour test would be run. This plan allows for comparison between rings that saw the same test conditions but with a different number of thermal cycles. At the same time, the metal coupons would be rinsed and measured for weight loss after each test run. The ceramic rings were microsectioned and analyzed to determine what mechanisms of corrosion had affected the coatings. Effluent analysis would indicate how much of the surrogates were retained in the system, providing an indicator of deposition.

The multilayered ceramic rings were designed to avoid delamination by a gradual change in the thermal coefficient of each layer. The high density top layer of the coatings was designed to prevent the absorption of metals or chlorides into the ceramic, though it was assumed that oxygen 
would be able to pass through. Perpendicular cracks exist in the ceramic layers so that the layers may expand and contract on the inside diameter of the ring. These cracks are apparent at low temperatures and close at higher temperatures. The results of the test showed that sometimes these cracks became the avenue for corrosive elements to travel down contacting nickel/chrome layers. Once corrosion products formed between the layers spalling or delamination mechanism would begin. Initial results were used to develop a titania coating onto a titanium ring. Though the same cracks were present in the titania coating, the corrosion did not occur between layers and there was no delamination after 120 to 180 hours of exposure.

The baseline metal coupons performed very badly as expected while the experimental nickel alloys performed better in all temperature zones. 


\section{ACKNOWLEDGMENTS}

The authors wish to thank Gary Fletcher and Del Miley of Lockheed Idaho Technologies Company for their contributions in the metallurgical analysis. The contributions of Ray Zatorski and Janet Lindsey of Engineered Coatings, Inc., and Vladimir Zilberstein of Stone \& Webster were critical to the success of the testing. Especially significant were the efforts of all the personnel at MODAR, Inc., whose creativity and cooperation are greatly appreciated. 


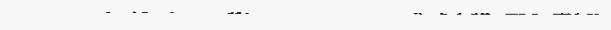




\section{CONTENTS}

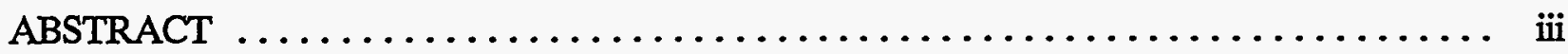

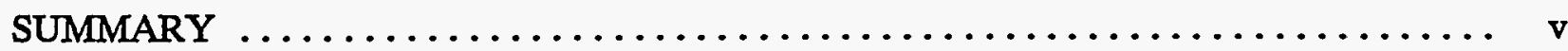

ACKNOWLEDGMENTS $\ldots \ldots \ldots \ldots \ldots \ldots \ldots \ldots \ldots \ldots \ldots \ldots \ldots \ldots \ldots \ldots \ldots$ vii

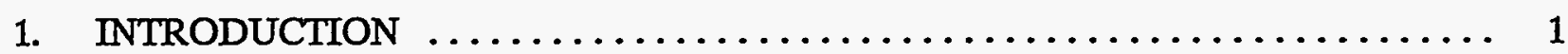

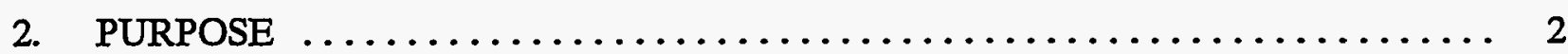

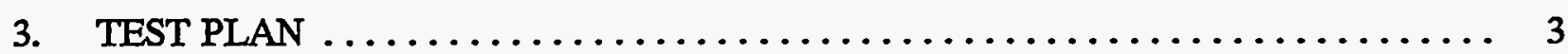

4. TEST SETUP $\ldots \ldots \ldots \ldots \ldots \ldots \ldots \ldots \ldots \ldots \ldots \ldots \ldots \ldots \ldots \ldots \ldots \ldots \ldots \ldots \ldots \ldots$

4.1 Description of Ceramic Ring Arrangement $\ldots \ldots \ldots \ldots \ldots \ldots \ldots \ldots \ldots$

4.2 Description of Metal Arrangement $\ldots \ldots \ldots \ldots \ldots \ldots \ldots \ldots \ldots \ldots \ldots \ldots$

5. COUPON DESCRIPTION $\ldots \ldots \ldots \ldots \ldots \ldots \ldots \ldots \ldots \ldots \ldots \ldots \ldots \ldots \ldots \ldots \ldots \ldots$

5.1 Plasma Sprayed Multilayered Ceramic Rings $\ldots \ldots \ldots \ldots \ldots \ldots \ldots \ldots, 7$

5.2 Experimental Nickel Alloys and Baseline Nickel Alloys $\ldots \ldots \ldots \ldots \ldots \ldots$

6. TEST EVENTS $\ldots \ldots \ldots \ldots \ldots \ldots \ldots \ldots \ldots \ldots \ldots \ldots \ldots \ldots \ldots \ldots \ldots \ldots \ldots \ldots \ldots$

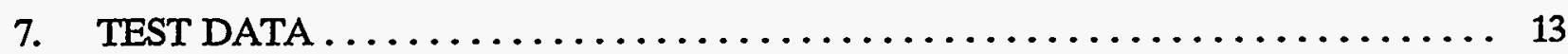

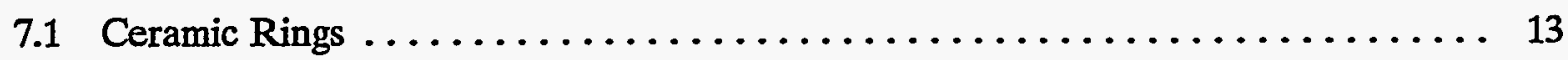

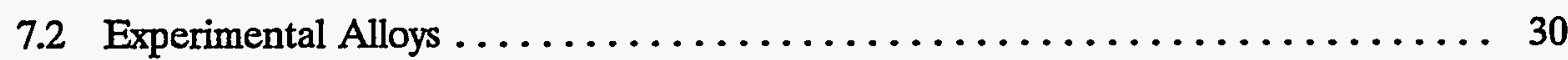

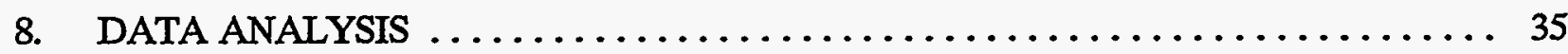

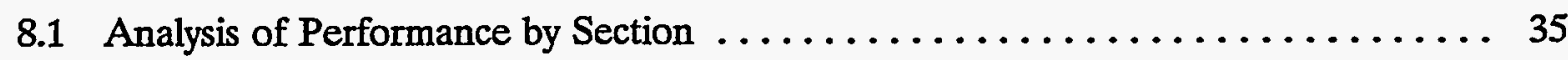

8.1.1 Section 1 Environment-Temperature $650^{\circ} \mathrm{C}, \mathrm{pH}$ of $0.8 \ldots \ldots \ldots \ldots 35$

8.1.2 Section 2 Environment-Temperature $600^{\circ} \mathrm{C}$, $\mathrm{pH}$ of $0.8 \ldots \ldots \ldots \ldots 37$

8.1.3 Section 3 Environment-Temperature $500^{\circ} \mathrm{C}$, $\mathrm{pH}$ of $0.8 \ldots \ldots \ldots \ldots 38$

8.1.4 Section 4 Environment-Temperature $400^{\circ} \mathrm{C}, \mathrm{pH}$ of $1.5 \ldots \ldots \ldots .39$

8.1.5 Section 5 Environment-Temperature $300^{\circ} \mathrm{C}$, pH of $1.5 \ldots \ldots \ldots .40$

8.2 Analysis of Performance by Material $\ldots \ldots \ldots \ldots \ldots \ldots \ldots \ldots \ldots \ldots$

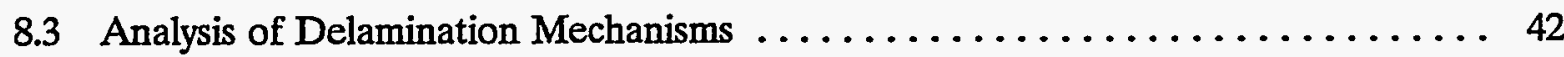




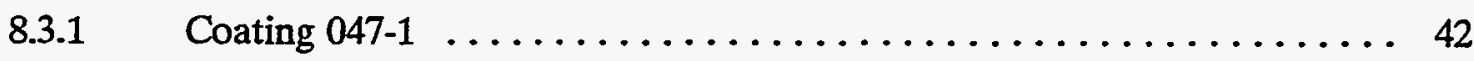

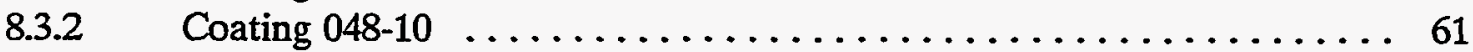

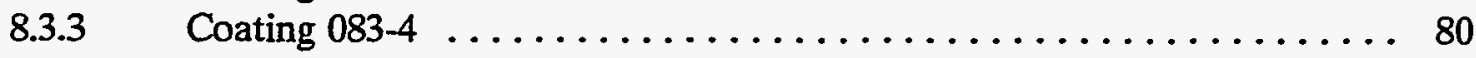

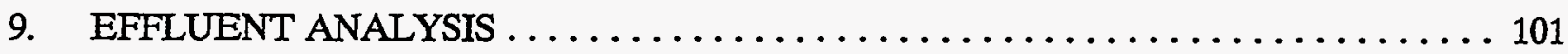

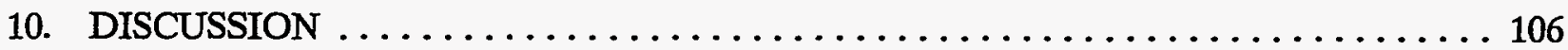

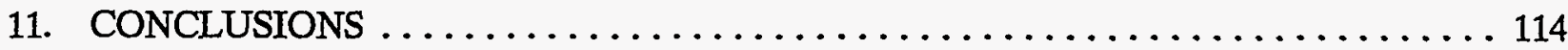

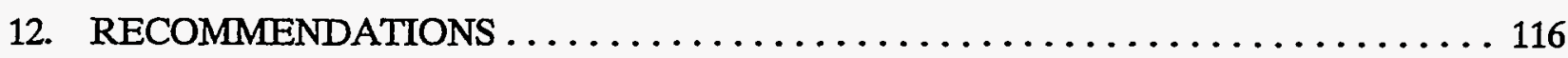

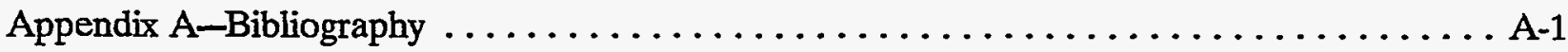

Appendix B-Engineering Design File $10121217 / 1032 \ldots \ldots \ldots \ldots \ldots \ldots \ldots \ldots$ B-1

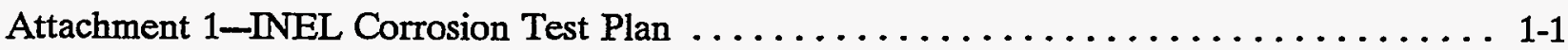

\section{FIGURES}

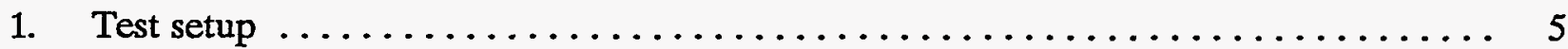

2. Temperature $-\mathrm{pH}$ profile $\ldots \ldots \ldots \ldots \ldots \ldots \ldots \ldots \ldots \ldots \ldots \ldots \ldots \ldots \ldots$

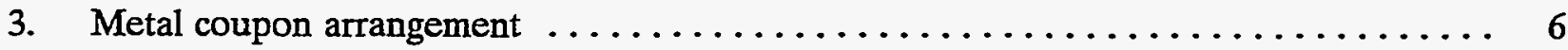

4. Condition of 047-1 (Coating A) (top) and 047-5 (Coating A) after first

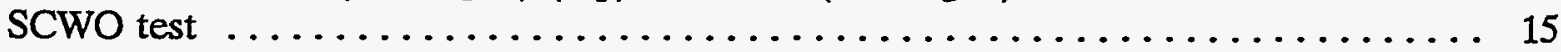

5. Condition of 048-6 (Coating B) (top) and 048-10 (Coating B) after first

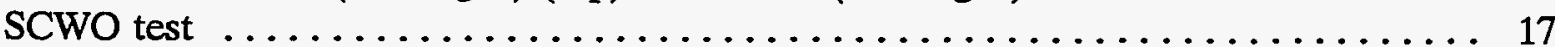

6. Condition of 049-11 (Coating C) (top) and 049-16 (Coating C) after first

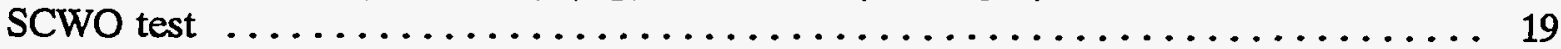

7. Condition of 049-12 (Coating C) (top), condition of 072-3 (Coating D) (middle), and condition of 073-5 (Coating E) after second SCWO test ......... 21

8. Condition of 060-5 (Coating C) and 071-1 (Coating C) $\ldots \ldots \ldots \ldots \ldots \ldots \ldots$

9. Condition of $082-1$ (Coating $\mathrm{C}$ ). $\mathrm{NiCrAl} / \mathrm{TiO}_{2}$ coating on titanium

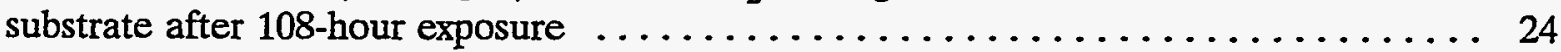

10. Condition of $083-4$ (F Coating). Ti-6Al-4V/TiO ${ }_{2}$ coating on titanium substrate intact after 108 hours of exposure in the bottom position of the reactor ........ 27 
11. Condition of $083-3$ and $083-5$. Ti-6 Al-4V/TiO ${ }_{2}$ coating on titanium substrate intact after 108 hours of exposure $\ldots \ldots \ldots \ldots \ldots \ldots \ldots \ldots \ldots \ldots \ldots \ldots$

12. Condition of $083-8$. Ti-6 Al-4V/TiO 2 coating on IN 625 ring showing lifting and spallation of the coating

13. Metal coupons from Section $1 \ldots \ldots \ldots \ldots \ldots \ldots \ldots \ldots \ldots \ldots \ldots \ldots \ldots \ldots$

14. Metal coupons from Section $5 \ldots \ldots \ldots \ldots \ldots \ldots \ldots \ldots \ldots \ldots \ldots \ldots \ldots \ldots \ldots$

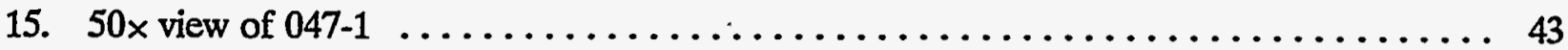

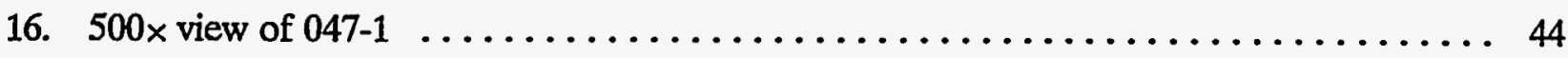

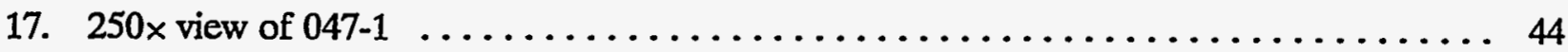

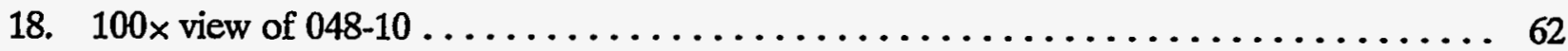

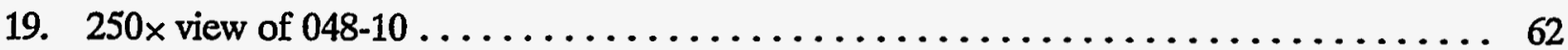

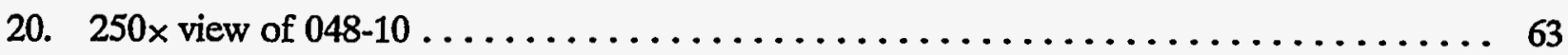

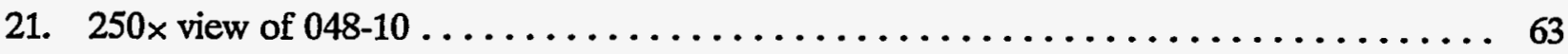

22. $1000 \times$ view of $083-4 \ldots \ldots \ldots \ldots \ldots \ldots \ldots \ldots \ldots \ldots \ldots \ldots \ldots \ldots \ldots \ldots \ldots$

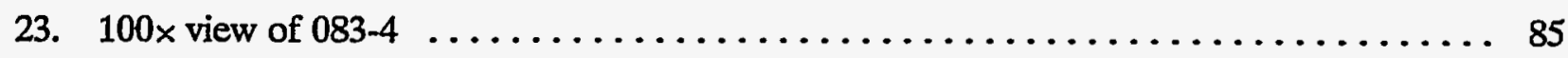

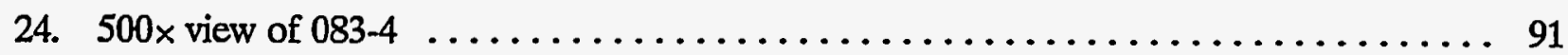

25. Mechanisms of failure for Ring 047-5, Coating A .................. 109

26. Mechanisms of failure for Ring $073-7$, Coating $C \ldots \ldots \ldots \ldots \ldots \ldots \ldots \ldots$

27. Mechanism of failure for Ring $073-7$, Coating $E \ldots \ldots \ldots \ldots \ldots \ldots \ldots \ldots$

28. Mechanism of failure for Ring $083-8$, Coating $F$, with Inconel ring $\ldots \ldots \ldots \ldots \ldots$

29. Mechanism of failure for Ring $083-4$, Coating $F$, with titanium ring $\ldots \ldots \ldots \ldots$

\section{TABLES}

1. Coating/ring descriptions for the 36 rings delivered $\ldots \ldots \ldots \ldots \ldots \ldots \ldots$

2. Chemistry of the nickel alloys $\ldots \ldots \ldots \ldots \ldots \ldots \ldots \ldots \ldots \ldots \ldots \ldots \ldots \ldots$

3. Calendar of test events during March to June $1994 \ldots \ldots \ldots \ldots \ldots \ldots \ldots \ldots$ 
4. Mils per year corrosion rate of the metal coupons $\ldots \ldots \ldots \ldots \ldots \ldots \ldots \ldots$

5. Shows the actual weight change in the metal coupons by section $\ldots \ldots \ldots \ldots$

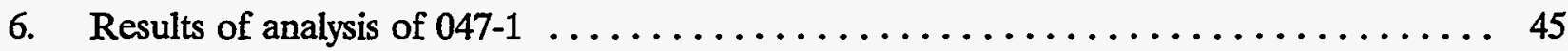

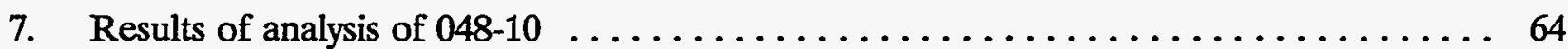

8. Results of analysis of areas shown in Figure $22 \ldots \ldots \ldots \ldots \ldots \ldots \ldots \ldots$

9. Results of analysis of areas shown in Figure $23 \ldots \ldots \ldots \ldots \ldots \ldots \ldots \ldots \ldots$

10. Results of analysis of areas shown in Figure $24 \ldots \ldots \ldots \ldots \ldots \ldots \ldots \ldots \ldots$

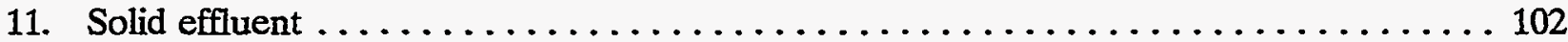

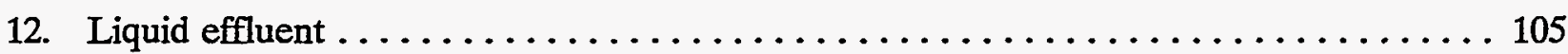

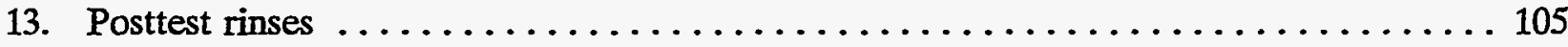




\section{Corrosion Investigation of Multilayered Ceramics and Experimental Nickel Alloys in SCWO Process Environments}

\section{INTRODUCTION}

The U.S. Department of Energy (DOE) has accelerated its efforts to convert its mixed waste inventories into disposable materials in the most efficient ways possible. In the past few years supercritical water oxidation (SCWO) has emerged as a technology capable of treating a portion of DOE mixed waste. For further information on the SCWO process, the reader is referred to the bibliography in Appendix A. Extensive testing done in cooperation with the private sector, universities, and other national laboratories has repeatedly shown that the major technical constraint of SCWO is the lack of practical materials of construction capable of withstanding the harsh environments of the SCWO process. A two-fold approach has been taken to overcome this constraint. Reactor designs have attempted to use fluid boundaries to keep the process fluids away from the reactor wall, and tests have been held to identify material systems suitable for the process. Future designs of pilot plants will incorporate the knowledge from both of these approaches.

Some of the different material systems that have been previously investigated $d^{\mathrm{a}}$ beyond the nickel alloys include ceramics, titanium, and the noble metals. The expense of noble metals is not practical as a structural component at a pilot-plant scale, and monolithic ceramics, though inexpensive, can be geometry dependent and too brittle for industrial handling. The approach taken in this work was thermally spraying multiple layers of ceramic onto a metal substrate. This process is widely used in industry, particularly the aerospace industry, for protecting components in harsh environments. A gradual change in thermal expansion properties allows each layer to expand and contract under thermal and pressure stresses without delamination. The multiple layers were sprayed onto the inside surfaces of rings for this experiment because this was considered the most relevant geometry to investigate for the SCWO process.

There are two particular environments of the SCWO process that are the most challenging. The first is the high temperature $\left(650^{\circ} \mathrm{C}\right)$ reaction zone where molten salts deposit onto substrates forming severe corrosion cells and the second is the transition temperature zone $\left(400-300^{\circ} \mathrm{C}\right)$ where the fluid changes from a supercritical phase to a subcritical phase and forms highly acidic liquids. The test was configured to place the ceramic rings and a variety of metal samples into both of these environments.

a. Telephone conversation with Mike Spritzer, General Atomics, July 23, 1993. 


\section{PURPOSE}

The purpose of this work was to fabricate and test a variety of multilayered ceramic coated rings in order to identify the response of the coating-substrate systems to the highly corrosive, high temperature, high pressure environment. The investigation was to determine if different coating-substrate systems reacted differently to the combination of thermal cycles, hoop stress, corrosion, and deposition of salts and metal oxides. It was the intention of the task that a practical, manufacturable material be identified. In addition to ceramic coating-substrate systems, various alloys were tested for comparison during the same tests. Inconel 625, C-22, and C-276 were included to serve as reference points. The composition and microstructure of these developed alloys would give insight into what elements were effective for corrosion resistance in an SCWO environment. 


\section{TEST PLAN}

The tests were run in the MODAR, Inc., pilot-scale SCWO system. The test conditions created an actual operating state within the MODAR reactor. The SCWO environment was created by using TrimSol mixed with water and air heated to produce a reaction at $650^{\circ} \mathrm{C}$ at 3,400 psi. TrimSol is a chlorinated machine cutting oil produced by Master Chemical Co. It is classified as $20-30 \%$ chlorinated alkene polymer combined with alkali petroleum sulfonate, alkyl phenol polyoxyl ethylene, and alkali fatty soap. Analysis shows the compound to consist of chlorine, 120,000 ppm; sodium, 4,990 ppm; sulfur, 9,140 ppm; and potassium, 1,750 ppm.

The following solids were added to simulate an actual DOE waste: $5,400 \mathrm{ppm} \mathrm{CeCl}_{3}$, $2,850 \mathrm{ppm} \mathrm{PbCl}_{2}$, and 2,250 ppm $\mathrm{ZnSO}_{4}$ (later changed to $\mathrm{ZnCl}$ ). These surrogates were chosen to compare the materials' behavior to a previous test. ${ }^{b}$ The TrimSol was pumped at 3,400 psi and $40 \mathrm{~mL} / \mathrm{min}$. It was mixed with the water and metals stream that had a flow rate of $80 \mathrm{~mL} / \mathrm{min}$. This was brought into the reactor and mixed with $350 \mathrm{~L} / \mathrm{min}$ air and $300 \mathrm{~mL} / \mathrm{min}$ of water heated up to $400^{\circ} \mathrm{C}$. Three tests were run. The first test was for 60 hours with five temperature cycles. The second was for 60 hours with just two temperature cycles. The third was for 120 hours with just two temperature cycles. It was anticipated that the temperature cycles would show if the ceramics tended toward delamination during startups or cooldown. For each temperature cycle the reaction zone was allowed to drop to below $300^{\circ} \mathrm{C}$.

Within the vessel reactor a casing was suspended downward from the nozzle, with an exit pipe at the bottom of the casing. The system configuration is shown in Attachment 1, Figures 1 and 2. A quench stream diluted the process effluent and neutralization occurred just before it exited the casing. Within the casing were 15 stacked rings. The rings were metal with multiple layers of ceramic coatings sprayed onto the inside of the rings. Each ring was 3 in. in height and $7 \mathrm{in.} \mathrm{in} \mathrm{diameter.} \mathrm{The} \mathrm{rings} \mathrm{were} \mathrm{cemented} \mathrm{together} \mathrm{inside} \mathrm{of} \mathrm{the} \mathrm{casing.} \mathrm{A} \mathrm{corrosion} \mathrm{rack} \mathrm{was}$ suspended down the center of the stack of rings and metal coupons were placed on branches of the corrosion rack. The length of the casing traversed five different temperature zones ranging from $650^{\circ} \mathrm{C}$ to $300^{\circ} \mathrm{C}$.

After the first 60-hour test, the top three and bottom three rings (six rings) would be removed and analyzed while three new rings were put into the top and bottom sections for the second 60-hour test. After the second 60-hour test, the top and bottom six rings (twelve rings) would be removed and replaced, and then the 120 -hour test would be run. This plan allowed for comparison between rings that saw the same test conditions but with a different number of thermal cycles. At the same time, the metal coupons would be rinsed and measured for weight loss after each test run and then placed back onto the coupon tree. The ceramic rings would then be microsectioned and analyzed to determine what mechanisms of corrosion had affected the coatings. Effluent analysis would indicate how much of the surrogates were retained in the system providing an indication of deposition.

b. C. Shapiro, K. Garcia, and J. M. Beller, "Treatment of a Simulated Mixed Waste with Supercritical Water Oxidation," Proceedings of the 2nd International Symposium on Mixed Waste, Baltimore, Maryland, August 17-20, 1993, pp 10.3.1-10.3.16. 


\section{TEST SETUP}

\subsection{Description of Ceramic Ring Arrangement}

There was a total of 36 rings. For each test, 15 coated rings, 3 in. high and 7 in. ID were stacked, cemented together, and placed inside a casing. The casing was mounted inside the MODAR SCWO vessel reactor.

The casing was $48 \mathrm{in.} \mathrm{long} \mathrm{and} \mathrm{included} \mathrm{five} \mathrm{sections} \mathrm{of} \mathrm{distinct} \mathrm{chemical/environmental}$ zones. See Figures 1 and 2 . Section 1 includes the top three rings and is defined as in the reaction zone. The temperature decreases through Section 4 where the quench water would be introduced and Section 5 is where the outlet tube mixes the process stream and diluted caustic to produce a neutralized effluent. The quench stream diluted the process effluent from about $8,000 \mathrm{ppm}$ of chloride concentration on an aqueous basis, down to $5,000 \mathrm{ppm}$ chloride concentration. The sulfate-to-chloride concentration was approximately 1:10. As the hot reaction products entered Section 4, they began to condense forming saltwater and acids. These liquids were quenched to a resulting $\mathrm{pH}$ of approximately 0.9 . Neutralization was carried out in Section 5 and created a brine with a pH of 6 at the bottom 2 in. of the test casing. The stream was not neutralized until just before it exited the casing through an exit pipe at the bottom of the casing. Neutralization was accomplished with sodium hydroxide in the first 60-hour test and with sodium bicarbonate thereafter. Due to the experimental design of stacking the rings, and the ceramic only covering the inside surface and not the edges of the rings, it was assumed that there would be edge attack on each of the rings where the metal substrate could be exposed. Only the middle 1 in. of the ring height would show valid corrosion mechanisms and coating performance. Air and water at $3,400 \mathrm{psi}$ and $400^{\circ} \mathrm{C}$ were introduced to the vessel reactor through an annulus while the TrimSol and water were brought to 3,400 psi and introduced to the SCWO reactor through a nozzle. The two streams mix, causing the reaction and forming reaction products containing chlorine, sodium, phosphorus, sulfur, calcium, cerium, zinc, and lead. The axial fluid temperature profile was monitored by thermocouples located within thermowells in the center of the casing.

\subsection{Description of Metal Arrangement}

The casing cover plate carried a vertical rod that spanned the entire length of the ring stack. Short horizontal threaded rods were welded to the vertical rod at each ring position. The rod and holders were made from Inconel 625 without any heat treatment after welding. Several metallic corrosion coupons were mounted onto each threaded rod. Ceramic washers were used as spacers between the coupons. Figure 3 shows this arrangement. 


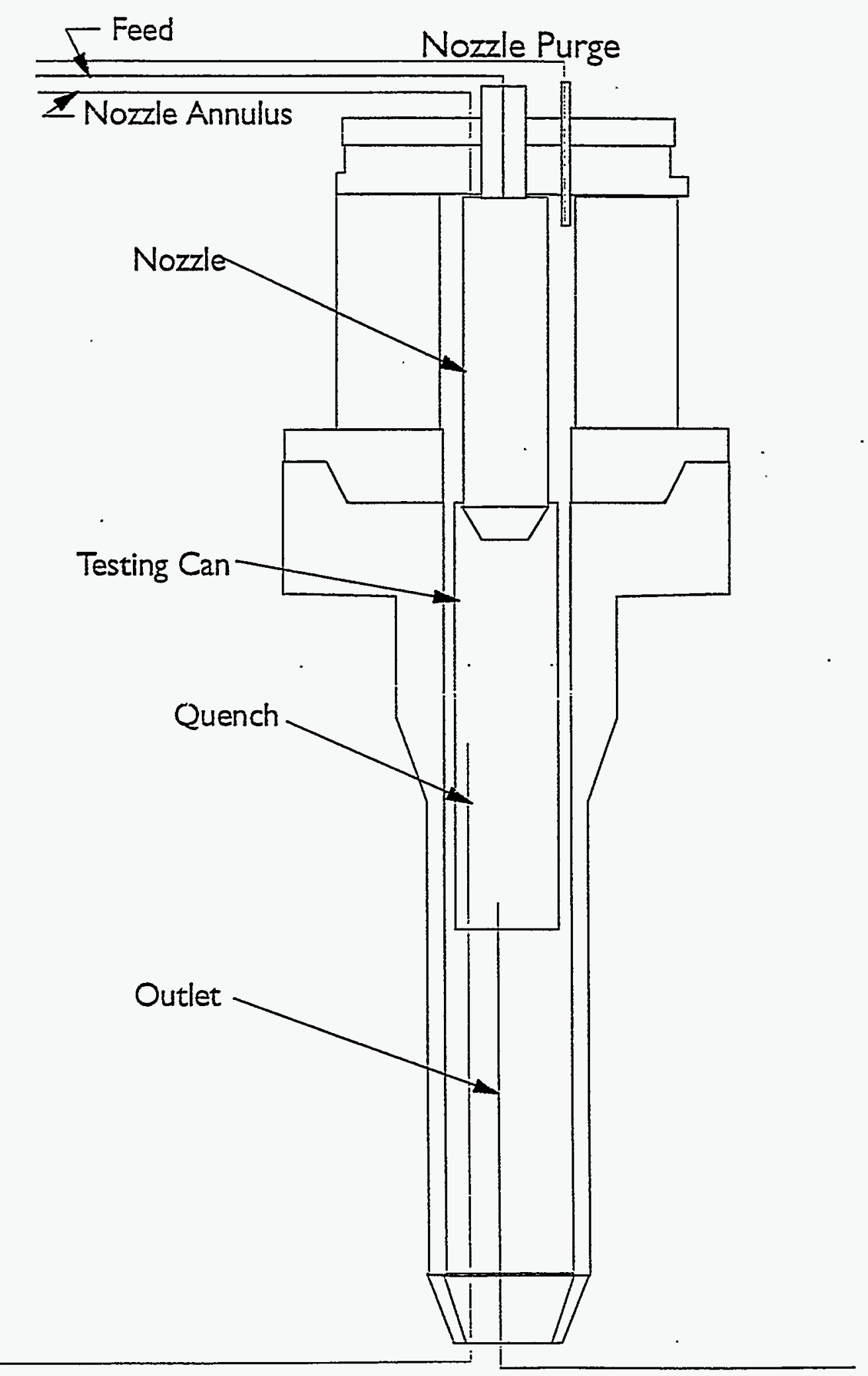

Figure 1. Test setup. 


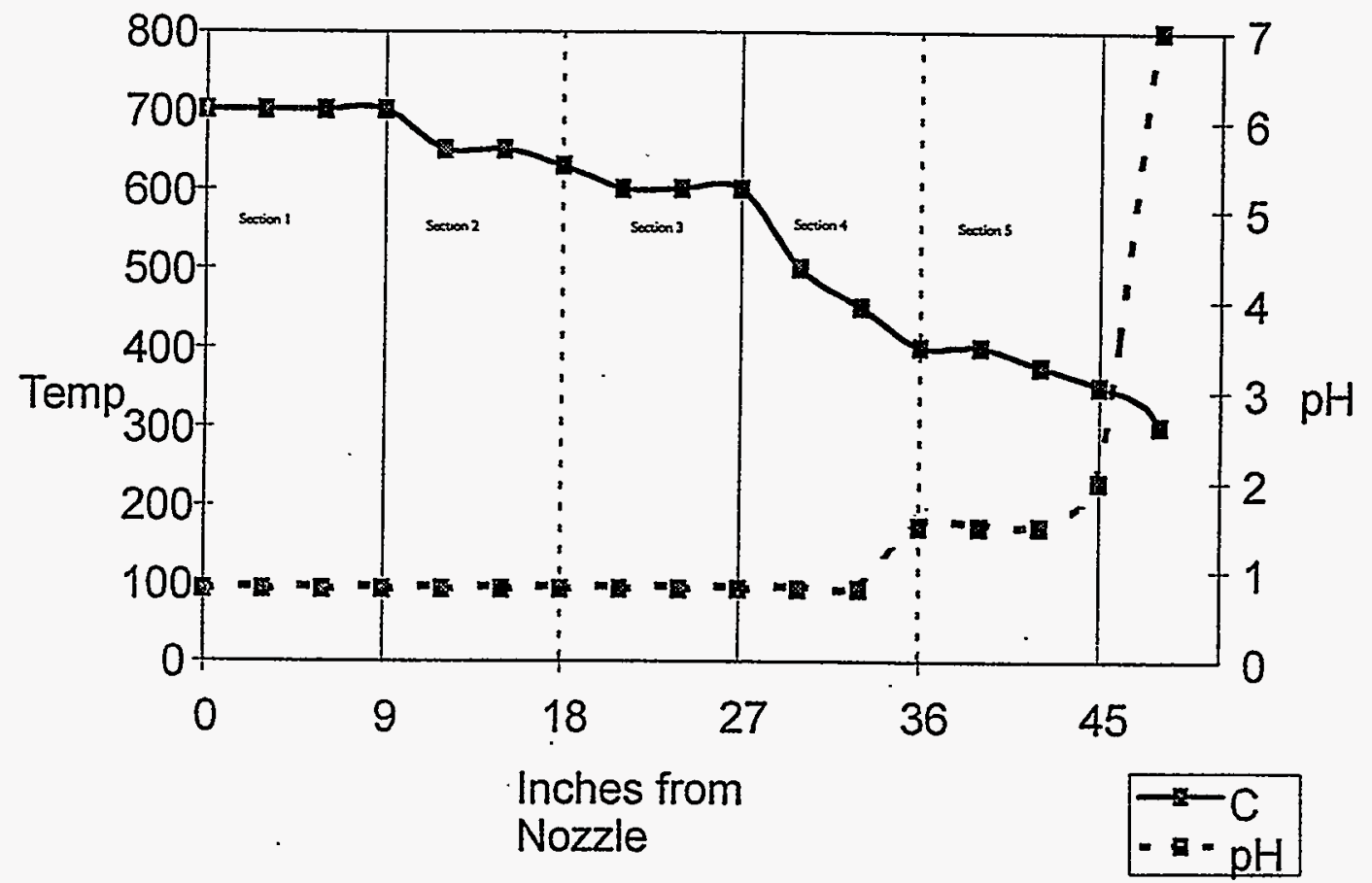

Figure 2. Temperature-pH profile.

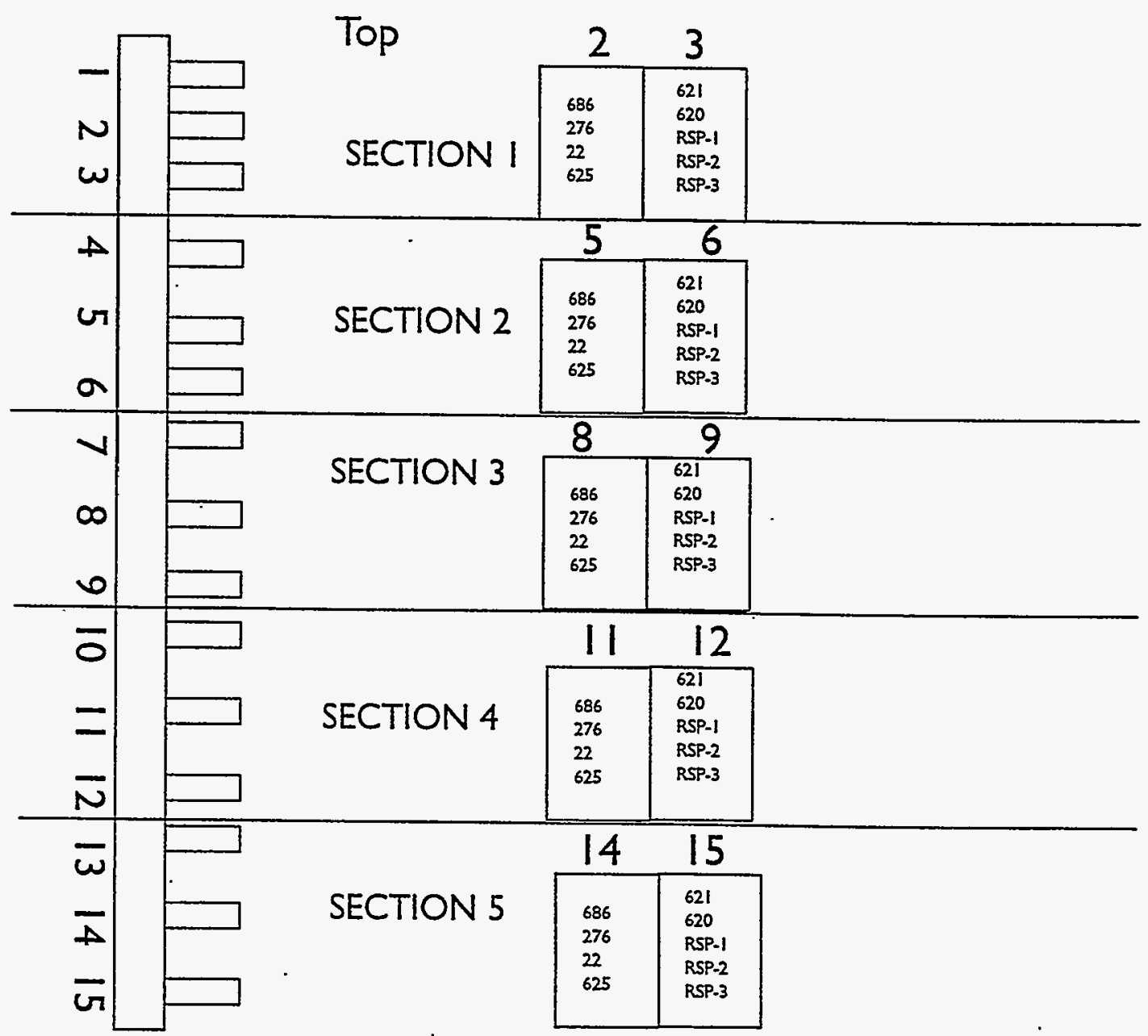

Figure 3. Metal coupon arrangement. 


\section{COUPON DESCRIPTION}

\subsection{Plasma Sprayed Multilayered Ceramic Rings}

Thermal spraying is a deposition technique where a heat source such as a combustion flame or nontransferred arc plasma is used to heat a feedstock in wire or powder to above the melting point of the material. The small, approximately $0.001 \mathrm{in} .(0.02 \mathrm{~mm})$ molten particles are propelled toward the substrate and freeze upon impact at a rate of $10^{5}$ to $10^{6}{ }^{\circ} \mathrm{C} / \mathrm{sec}$. The spray parameters and the rate of material deposited onto the surface is adjusted to maintain the substrate at a desired temperature to obtain certain levels of residual stress. The lower range of these temperatures is from less than $250^{\circ} \mathrm{F}\left(121^{\circ} \mathrm{C}\right)$ to over $1000^{\circ} \mathrm{F}\left(537^{\circ} \mathrm{C}\right)$. Thermal spraying is an industrial technique for coating a range of components from gas turbines for hot corrosion and erosion protection to machine element buildup where heat distortion cannot be tolerated through aluminum and zinc coatings for atmospheric and marine corrosion protection. Spray rates range from $5 \mathrm{lbs} / \mathrm{hr}(2.2 \mathrm{~kg} / \mathrm{hr})$ for ceramics to $40 \mathrm{lbs} / \mathrm{hr}(18 \mathrm{~kg} / \mathrm{hr}$ ) for metals. Most production coatings are applied with automated systems. The annual value of thermally sprayed coatings in the U.S. is estimated above $\$ 1$ billion.

The practical lower limit for each layer of coating thickness is 0.003 in. $(0.07 \mathrm{~mm})$ for a continuous coating. Most materials can be sprayed to thicknesses in excess of $0.5 \mathrm{in}$. (13 mm). This line of sight process deposits coatings in layers typically 0.0005 in. $(0.013 \mathrm{~mm})$ with each pass of the spray device. Multiple passes of the spray device are made to achieve the desired thickness. There is a porosity associated with the sprayed deposit of between $0.2 \%$ and $12 \%$ depending on spray parameters and material. In many applications this porosity does not effect service.

The eight different combinations of coatings and rings were defined as A, B, C, C', D, E, F, and $F^{\prime}$. Thirty of the rings used Inconel 625 as the substrate and six used titanium as the substrate. Of the six titanium rings, four were $\mathrm{Gr} 2$ and two were $\mathrm{Gr} 12$ titanium. The thermal spray technique can be adjusted such that the residual stress in the coating is at a minimum at a chosen temperature. The coatings were designed to be at the minimum stress at a midpoint temperature between the high temperature of $650^{\circ} \mathrm{C}$ and room temperature. See Table 1 for the coating thicknesses. The coatings were designed for a high density top layer. In cases where porosity is of concern, the coating parameters can be adjusted to reduce the porosity to below the level where the pores are interconnected. The porosity and microcracks in the coating allow additional expansion and contraction in the coating system to better match the substrates movement due to stresses. The coating must eventually be evaluated in the service environment to determine the best compromise for the levels of porosity and allowable stress.

The approach to designing a coating system was to select a bond coat similar in thermal properties to the substrate. The bond coat was a nickel/chrome/aluminum combination for 29 of the rings and seven rings received a titanium/alumina/vanadium combination. Of those seven, five had a titanium substrate and two had an Inconel 625 substrate. A common concern is the interlayer adhesive strength of the layers. A graded transition is put between the layers by alternating materials. For example, during the titanium to titania transition, a mixture of titanium and titania is sprayed to increase the intermediate layer's bond strength. 
Table 1. Coating/ring descriptions for the 36 rings delivered.

First set-15 rings Layers/average thicknesses

\begin{tabular}{|l|l|l|l|l|l|l||}
\hline Run number & Ctg./ring spec. & Ring no./mat'l. & NiCrAl bond & NiCrAl/7\%YZ & $7 \%$ Y \\
\hline $5(032494) 047$ & A & $1^{*}, 1-625$ & 0.004 in. & 0.007 in. & 0.036 in. & \\
\hline & & $2-5,1-625$ & 0.004 in. & 0.007 in. & 0.024 in. & \\
\hline & & & NiCrAl bond & NiCrAl/7\%YZ & Alumina & $7 \%$ Y \\
\hline $5(032494) 048$ & B & $6 *, 1-625$ & 0.004 in. & 0.007 in. & 0.013 in. & 0.016 in. \\
\hline & & $7-10,1-625$ & 0.004 in. & 0.006 in. & 0.007 in. & 0.015 in. \\
\hline $5(032594) 049$ & C & & NiCrAl bond & NiCrAl/TiO 2 & TiO 2 & \\
\hline & & $16 *, 1-625$ & 0.004 in. & 0.010 in. & 0.017 in. & \\
\hline
\end{tabular}

Second set -6 rings

\begin{tabular}{|l|l|l|l|l|l|l||}
\hline Run number & Ctg./ring spec. & Ring no./mat'l. & NiCrAl bond & NiCrAl/7\%YZ & $7 \% Y Z$ \\
\hline $5(040894) 058$ & A & $1,1-625$ & 0.006 in. & 0.007 in. & 0.016 in. & \\
\hline & & $2,1-625$ & 0.006 in. & 0.008 in. & 0.013 in. & \\
\hline & & & NiCrAl bond & NiCrAl/7\%YZ & Alumina & $7 \% Y Z$ \\
\hline $5(040894) 059$ & B & $3,1-625$ & 0.006 in. & 0.007 in. & 0.004 in. & 0.012 in. \\
\hline & & $4,1-625$ & 0.006 in. & 0.007 in. & 0.004 in. & 0.015 in. \\
\hline $5(040894) 060$ & C & & NiCrAl bond & NiCrAl/TiO 2 & TiO 2 & \\
\hline & & $5,1-625$ & 0.006 in. & 0.005 in. & 0.016 in. & \\
\hline
\end{tabular}

Third set-7 rings

\begin{tabular}{|c|c|c|c|c|c|c|}
\hline Run number & Ctg./ring spec. & Ring no./mat'l. & NiCrAl bond & $\mathrm{NiCrAl} / \mathrm{TiO}_{2}$ & $\mathrm{TiO}_{2}$ & \\
\hline \multirow[t]{2}{*}{$5(042594) 071$} & $\mathrm{C}$ & $1,1-625 \cdots$ & 0.005 in. & 0.005 in. & 0.013 in. & \\
\hline & & & NiCrAl bond & $\mathrm{NiCrAl} / \mathrm{TIO}_{2}$ & $\mathrm{TiO}_{2}$ & $7 \% Y Z$ \\
\hline \multirow[t]{3}{*}{$5(042594) 072$} & D & $4^{*}, 1-625$ & 0.004 in. & 0.005 in. & 0.011 in. & 0.007 in. \\
\hline & & $2-3,1-625$ & 0.004 in. & 0.005 in. & 0.011 in. & 0.007 in. \\
\hline & & & NiCrAl bond & $\mathrm{NiCrAl} / \mathrm{TIO}_{2}$ & $\mathrm{TiO}_{2}$ & $24 \% \mathrm{MgZ}$ \\
\hline \multirow[t]{3}{*}{$5(042594) 073$} & $E$ & $7^{\star}, 1-625$ & 0.005 in. & 0.005 in. & 0.011 in. & 0.006 in. \\
\hline & & $5,1-625$ & 0.005 in. & 0.005 in. & $0.011 \mathrm{in}$ & 0.011 in. \\
\hline & & $6,1-625$ & 0.005 in. & 0.005 in. & 0.011 in. & 0.006 in. \\
\hline
\end{tabular}


Table 1. (continued).

Fourth set-8 rings

\begin{tabular}{|c|c|c|c|c|c|}
\hline Run number & Ctg./ring spec. & Ring no./mat'l. & NiCrAl bond & $\mathrm{NiCrAl} / \mathrm{TiO}_{2}$ & $\mathrm{TiO}_{2}$ \\
\hline \multirow[t]{2}{*}{$5(052794) 082$} & $c^{\prime}$ & 1, Gr 2 Titanium & 0.004 in. & 0.005 in. & 0.013 in. \\
\hline & & & Ti-6Al-4V bond & $\mathrm{Ti}-6 \mathrm{Al}-4 \mathrm{~V} / \mathrm{TiO}_{2}$ & $\mathrm{TO}_{2}$ \\
\hline \multirow[t]{4}{*}{$5(052794) 083$} & $F$ & $2^{*}$, Gr 2 Titanium & 0.007 in. & 0.005 in. & 0.015 in. \\
\hline & & $3-4$, Gr 2 Titanium & 0.004 in. & 0.005 in. & 0.015 in. \\
\hline & & $.5-6, \operatorname{Gr} 12$ Titanium & 0.004 in. & 0.006 in. & 0.015 in. \\
\hline & $F^{\prime}$ & $7-8,1-625$ & 0.004 in. & 0.006 in. & 0.015 in. \\
\hline
\end{tabular}

There were two types of zirconia top coats, a zirconia partially stabilized with 7\% yttria, and a zirconia partially stabilized with $24 \%$ magnesia. See Table 1 for each coating description.

Coating $\mathrm{A}$ was the basic design with the nickel/chrome/aluminum bond coat, then a transition coat of nickel/chrome/aluminum/7\% partially stabilized yttria/zirconia ( $7 \% \mathrm{YZ}$ ). The top coat was $7 \% \mathrm{YZ}$ chosen because previous corrosion tests have shown good performance of zirconia in SCWO environments. ${ }^{c}$

For Coating $\mathrm{B}$ an additional alumina interlayer was added beneath the $7 \% \mathrm{YZ}$. Coating $\mathrm{C}$ used the same bond coat as Coatings $A$ and $B$ but had a transition layer of nickel/chrome/aluminum/titania and a top coat of titania. Coating $\mathrm{D}$ was the same as Coating $\mathrm{C}$ but with an added top layer of $7 \% \mathrm{YZ}$. Coating $\mathrm{E}$ was again the same as Coating $\mathrm{C}$ but with an added top layer of $24 \% \mathrm{MgZ}$.

Coating $\mathrm{F}$ was a complete titania/titanium system on a titanium ring. The bond coat was titanium/aluminum/vanadium, the transition coat was titanium/aluminum/vanadium/titania, and the top coat was titania. Coating $F^{\prime}$ was the same except the substrate was Inconel 625.

\subsection{Experimental Nickel Alloys and Baseline Nickel Alloys}

The chemistry of the nickel alloys is given in Table 2. The following NiCrMo alloys were chosen for the test program: Inconel 625, Hastelloy C-276, Inconel 686, Hastelloy C-22, and alloys 620 and 621 alloys (experiential alloys developed between the INEL and Haynes International).

c. Telephone conversation with Mike Spritzer, General Atomics. 
Table 2. Chemistry of the nickel alloys.

\begin{tabular}{|l|l|l|l|l|l|l|l|l|l|l|l|l|l|l||}
\hline Alloy & Heat & $\mathrm{Al}$ & $\mathrm{C}$ & $\mathrm{Cr}$ & $\mathrm{Cu}$ & $\mathrm{Fe}$ & $\mathrm{Mn}$ & $\mathrm{Mo}$ & $\mathrm{Ni}$ & $\mathrm{P}$ & $\mathrm{S}$ & $\mathrm{Si}$ & $\mathrm{Ti}$ & Others \\
\hline C-276 & $\mathrm{J} 018$ & & .003 & 15.26 & & 5.35 & .48 & 15.39 & Balance & .007 & .002 & .02 & & $\begin{array}{l}\text { Co-1.35; } \\
\text { V-.13; W-3.3 }\end{array}$ \\
\hline C-22 & H159 & & .003 & 21.20 & & 4.5 & .25 & 13.3 & Balance & .006 & .003 & .38 & & $\begin{array}{l}\text { Co-1.96; } \\
\text { V-.14; W-3.0 }\end{array}$ \\
\hline I-625 & J186 & .23 & .02 & 21.89 & & 3.34 & .05 & 8.97 & 61.68 & .007 & .001 & .13 & .25 & Cb+Ta-3.42 \\
\hline I-686 & K065 & .22 & .01 & 20.40 & .01 & 1.03 & .23 & 16.42 & 57.42 & .006 & .001 & .02 & .04 & $\begin{array}{l}\text { Co-.04; } \\
\text { Cb-08; } \\
\text { W-4.06 }\end{array}$ \\
\hline C-22 & RSP1 & & .003 & 21.20 & & 4.5 & .25 & 13.3 & Balance & .006 & .003 & .38 & & $\begin{array}{l}\text { Co-1.96; } \\
\text { V-.14; W-3.0 }\end{array}$ \\
\hline Finn & RSP2 & & & 25 & & 15 & & 3 & Balance & & & & & Nio-5.5 \\
\hline Flinn & RSP3 & & & 25 & & 15 & & & Balance & & & 2.5 & & \\
\hline Mizia & 620 & & & 25 & & & & 9.89 & Balance & & & & & W-3.0 \\
\hline Mizia & 621 & & & 25 & & & & 12.51 & Balance & & & & & W-3.0 \\
\hline
\end{tabular}




\section{TEST EVENTS}

The goal of Run 937 was to establish the flow rates needed to get the desired temperature profile in the reactor. The temperature at the nozzle was greater than $600^{\circ} \mathrm{C}$, the temperature 18 in. below the nozzle was greater than $550^{\circ} \mathrm{C}, 36 \mathrm{in}$. below the nozzle was approximately $400^{\circ} \mathrm{C}$, and $42 \mathrm{in}$. below the nozzle was approximately $300^{\circ} \mathrm{C}$.

Lead sulfate precipitated from the feed mixture in Run 937. An estimated $2 \%$ of the lead made it into the feed stream. The zinc sulfate was switched to zinc chloride to alleviate the problem. This run showed flaking, peeling, and separation of ceramic coating from all the rings except those composed of titania. The Type A and B coatings showed severe delamination so all were replaced. Thirteen rings were replaced including three titania rings.

In Run 939/940, the quench water inlet tube was extended up 3 in. with two horizontal streams of water coming out at 180 -degree angle. The second 60 -hour test was conducted without the five thermal cycles of Run 937/938. See Table 3. This would show if the multiple thermal cycles were the principal difficulty. The performance of the titania coating was better than the zirconia coatings. Further testing focused on several versions of a titania coating system.

In Run 941/942, the 120-hour run had more titania coating rings added and some $\mathrm{ZrO}_{2}$ coatings were reused to fill the necessary 15 slots. One titania coated on Inconel ring saw a total of 240 hours while three titania on titanium saw a total of 180 hours.

A calendar of the test events is outlined in Table 3. The system was shut down by cutting off all feeds at once. This is called a hot dry shutdown. This allows for deposition to be observed. 
Table 3. Calendar of test events during March to June 1994.

\begin{tabular}{|c|c|c|c|c|c|c|}
\hline Monday & Tuesday & Wed & Thursday & Friday & Saturday & Sunday \\
\hline $03 / 28$ & $03 / 29$ & $\begin{array}{l}03 / 30 \\
\text { Testing starts } \\
\text { with IPA }\end{array}$ & $\begin{array}{l}03 / 31 \\
\text { Testing starts } \\
\text { with TrimSol } \\
\text { Run } 937 \\
\text { Hot dry shut } \\
\text { down }\end{array}$ & $\begin{array}{l}04 / 01 \\
\text { Testing can is } \\
\text { pulled }\end{array}$ & $04 / 02$ & $04 / 03$ \\
\hline $\begin{array}{l}\text { 04/04 Metal } \\
\text { Coupons } \\
\text { rinsed and } \\
\text { observed }\end{array}$ & $\begin{array}{l}\text { 04/05 } \\
\text { System shut } \\
\text { down }\end{array}$ & $\begin{array}{l}\text { 04/06 System } \\
\text { brought back } \\
\text { on line Run } \\
938\end{array}$ & $\begin{array}{l}04 / 07 \text { Hot } \\
\text { dry shutdown } \\
\text { to observe } \\
\text { nozzle then } \\
\text { system } \\
\text { started again }\end{array}$ & $\begin{array}{l}04 / 08 \text { System } \\
\text { shut down } \\
\text { after } 26.2 \mathrm{hr} \\
\text { of } 60 \text {-hr test } \\
\text { run \#938 }\end{array}$ & $04 / 09$ & $04 / 10$ \\
\hline $\begin{array}{l}04 / 11 \\
\text { System start } \\
\text { up Run } 938\end{array}$ & $\begin{array}{l}04 / 12 \\
\text { Hot dry } \\
\text { shutdown for } \\
\text { cycle \#4 }\end{array}$ & $\begin{array}{l}\text { 04/13 System } \\
\text { shut down } \\
\text { End of first } \\
60 \text {-hr run }\end{array}$ & $\begin{array}{l}04 / 14 \\
13 \text { rings. } \\
\text { pulled and } \\
\text { replaced }\end{array}$ & $\begin{array}{l}04 / 15 \\
\text { System shut } \\
\text { down }\end{array}$ & $04 / 16$ & $04 / 17$ \\
\hline $04 / 18$ & $04 / 19$ & $04 / 20$ & $04 / 21$ & $04 / 22$ & $04 / 23$ & $04 / 24$ \\
\hline $04 / 25$ & $04 / 26$ & $04 / 27$ & $04 / 28$ & $04 / 29$ & $04 / 30$ & $05 / 01$ \\
\hline $\begin{array}{l}05 / 02 \\
\text { Run } 939 \\
\text { starts } \\
\end{array}$ & $\begin{array}{l}05 / 03 \\
\text { Run } 939 \\
\text { stops }\end{array}$ & $\begin{array}{l}\text { 05/04 } \\
\text { System shut } \\
\text { down }\end{array}$ & $\begin{array}{l}05 / 05 \\
\text { System shut } \\
\text { down }\end{array}$ & $\begin{array}{l}05 / 06 \\
\text { System shut } \\
\text { down }\end{array}$ & $05 / 07$ & $05 / 08$ \\
\hline $\begin{array}{l}05 / 09 \\
\text { System shut } \\
\text { down }\end{array}$ & $\begin{array}{l}05 / 10 \\
\text { System shut } \\
\text { down }\end{array}$ & $\begin{array}{l}05 / 11 \\
\text { Run } 940 \\
\text { starts }\end{array}$ & $\begin{array}{l}05 / 12 \\
\text { Run } 940\end{array}$ & $\begin{array}{l}05 / 13 \\
\text { Run } 940 \\
\text { ends. End of } \\
\text { 2nd } 60 \text {-hr run }\end{array}$ & $\begin{array}{l}05 / 14 \\
8 \text { rings pulled } \\
\text { and replaced }\end{array}$ & $05 / 15$ \\
\hline $05 / 16$ & $05 / 17$ & $05 / 18$ & $05 / 19$ & $05 / 20$ & $05 / 21$ & $05 / 22$ \\
\hline $05 / 23$ & $05 / 24$ & $05 / 25$ & $05 / 26$ & $05 / 27$ & $05 / 28$ & $05 / 29$ \\
\hline $\begin{array}{l}\text { 05/30 } \\
\text { System shut } \\
\text { down }\end{array}$ & $\begin{array}{l}\text { 05/31 } \\
\text { System shut } \\
\text { down }\end{array}$ & $\begin{array}{l}06 / 01 \\
\text { System shut } \\
\text { down }\end{array}$ & $\begin{array}{l}06 / 02 \\
\text { Run } 941 \\
\text { begins }\end{array}$ & $\begin{array}{l}06 / 03 \\
\text { Run } 941\end{array}$ & $\begin{array}{l}06 / 04 \\
\text { Run } 941 \text { ends }\end{array}$ & $06 / 05$ \\
\hline $\begin{array}{l}06 / 06 \\
\text { Run } 942 \\
\text { begins }\end{array}$ & $\begin{array}{l}06 / 07 \\
\text { Run } 942\end{array}$ & $\begin{array}{l}06 / 08 \\
\text { Run } 942\end{array}$ & $\begin{array}{l}06 / 09 \\
\text { Run } 942\end{array}$ & $\begin{array}{l}06 / 10 \\
\text { Run } 942\end{array}$ & $\begin{array}{l}06 / 11 \\
\text { Run } 942 \text { ends }\end{array}$ & $06 / 12$ \\
\hline
\end{tabular}




\section{TEST DATA}

\subsection{Ceramic Rings}

The test data are described here in approximate chronological order of the rings that were tested. The successful titania coatings are described last because the decision to go to an all-titania system was only made after the initial 60 -hour test results. The ceramic coating was only on the inside of each ring. The substrate was exposed on the top edge of each ring. Edge degradation was expected and was not considered as a failure of the coating. The ring numbering system is derived from the manufacturing numbers (see Table 1 for the composition information). 
The following photographs (Figure 4) show the condition of 047-1 (Coating A) and 047-5 (Coating A) after testing. Although both rings have the same coating, they were in two different sections of the test. 047-1 was in Section 1 while 047-5 was in Section 5 during the first 60-hour test. 047-1 had salt deposits and the coating was blistering while 047-5 had already delaminated. The lower temperature section degraded Coating A more than the high temperature zone. Three other rings had similar coatings and were in the first 60-hour test. After the test the rings were described as follows:

- $\quad$ 047-2 Coating A Blistering, peeling, edge chipping

- 047-3 Coating A A few blisters, and edge chipping

- $\quad$ 047-4 Coating A A few blisters, some erosion. 

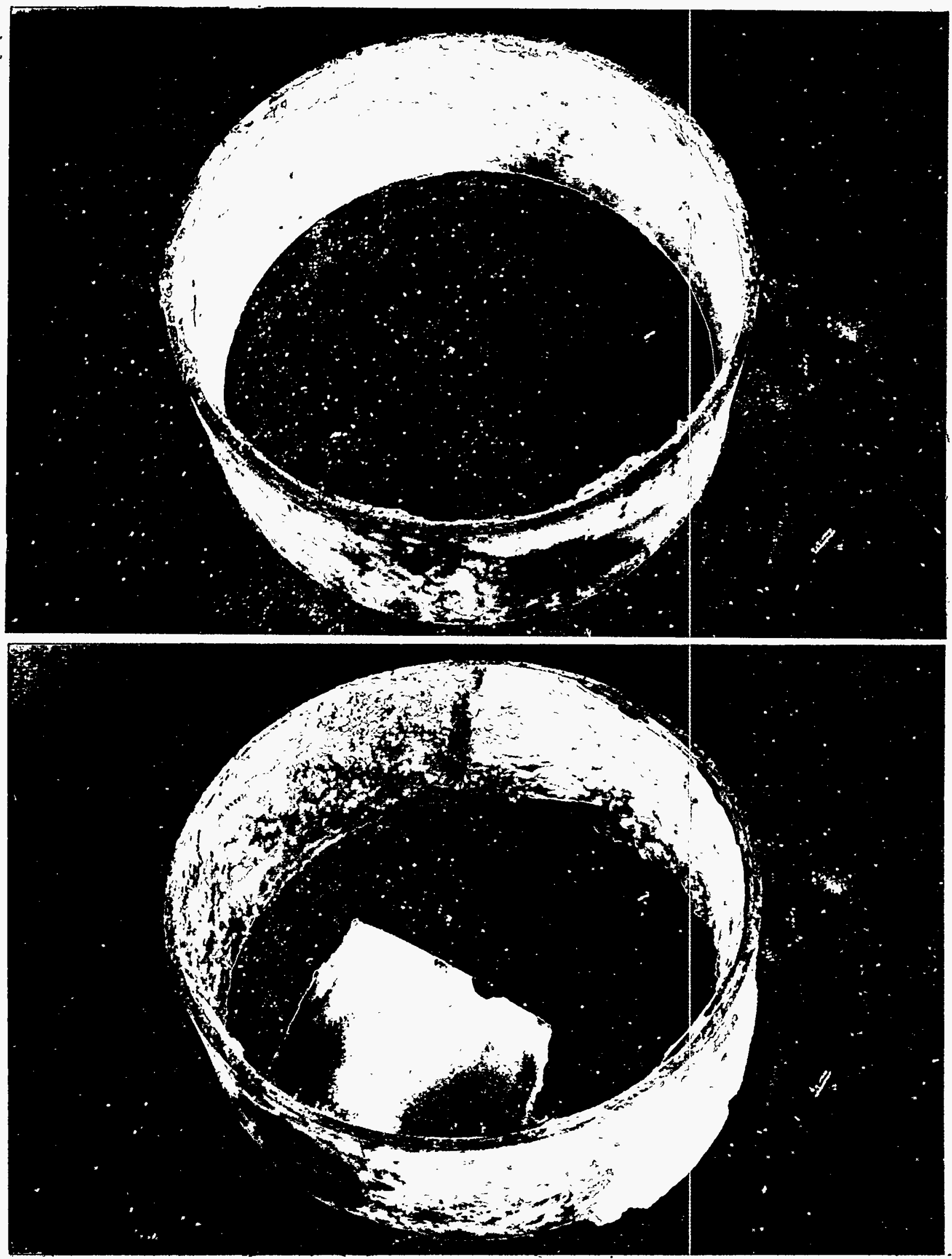

Figure 4. Condition of 047-1 (Coating A) (top) and 047-5 (Coating A) after first SCWO test. 
The following photographs (Figure 5) show the condition of 048-6 (Coating B) and 048-10 (Coating B). Coating B was the same as Coating A except an alumina interlayer had been added. 048-6 is from Section 1 and 048-10 is from Section 5 during the first 60-hour test. The temperature range was not as significant to this type of coating as both of these rings delaminated. Three other rings had similar coatings and were in the first 60-hour test. After the test, the rings were described as follows:

- 048-7 B Blistering, peeling, disengagement; delamination at alumina layer

- $\quad$ 048-8 B Blistering, peeling, disengagement

- 048-9 B Cracks, disengagement, and blistering.

Three other rings from the second 60-hour test: 058-1 (Coating A) from Section 1, 058-2 (Coating A) from Section 5, and 059-3 (Coating B) from Section 1 were described as having delaminated.

The ring 059-4 (Coating B) had cracking from an edge attack after 60 hours in Section 5, after an additional 120 hours in Section 2 the coating was gone over $80 \%$ of ring. 

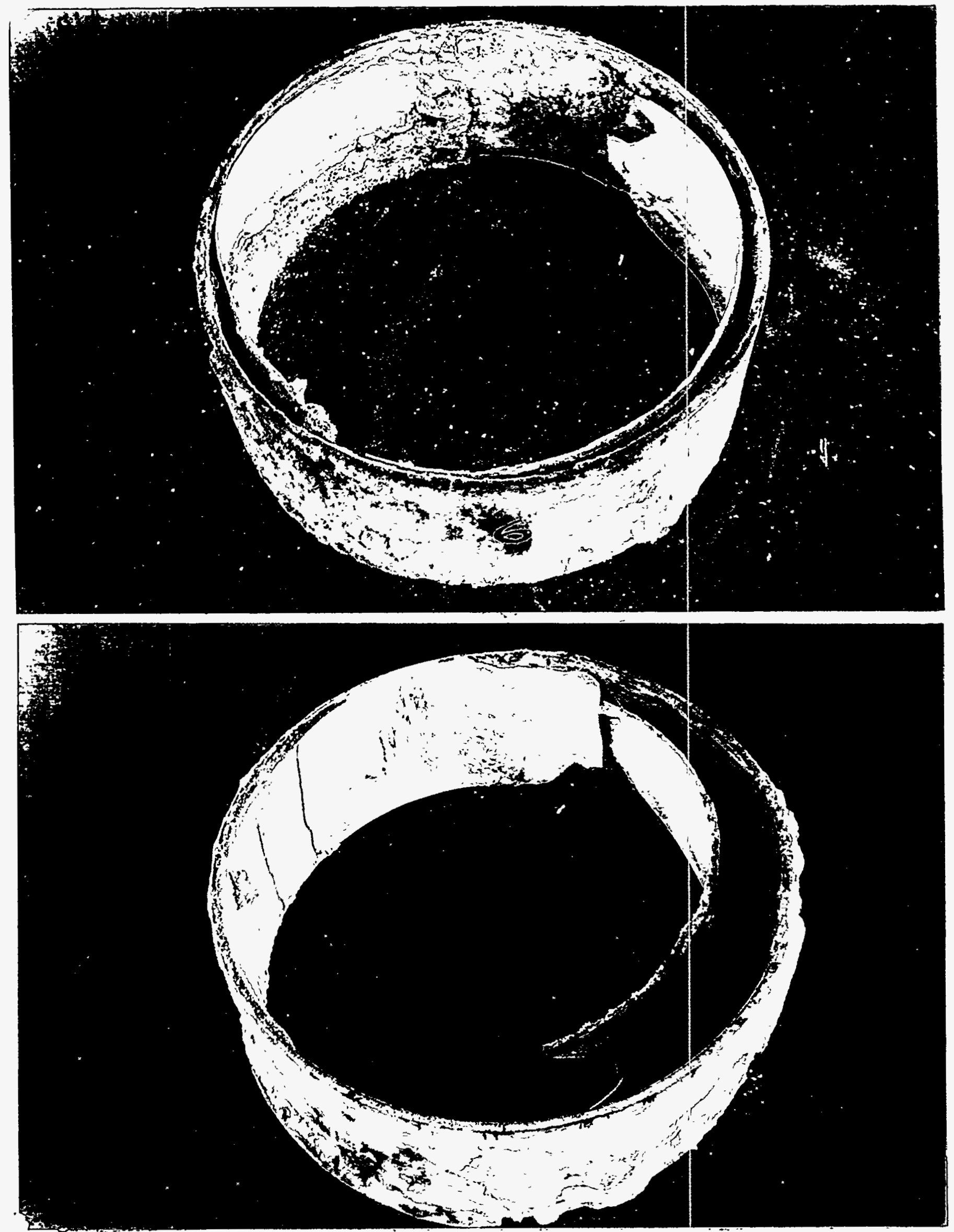

Figure 5. Condition of 048-6 (Coating B) (top) and 048-10 (Coating B) after first SCWO test. 
The following photographs (Figure 6) show the condition of 049-11 (Coating C) and 049-16 (Coating C). 049-11 is from Section 1 and 049-16 is from Section 5 during the first 60-hour test. Both of these rings did well after 60 hours. The brine line can be seen in 049-16 as it was the lowest ring in the stack. The top 1 in. of the 049-16 ring shows the edge attack on the coating. The other ring removed after the first 60-hour test was the 049-14 (Coating C) in Section 4 because of edge infiltration causing cracks and corrosion of the base metal. 

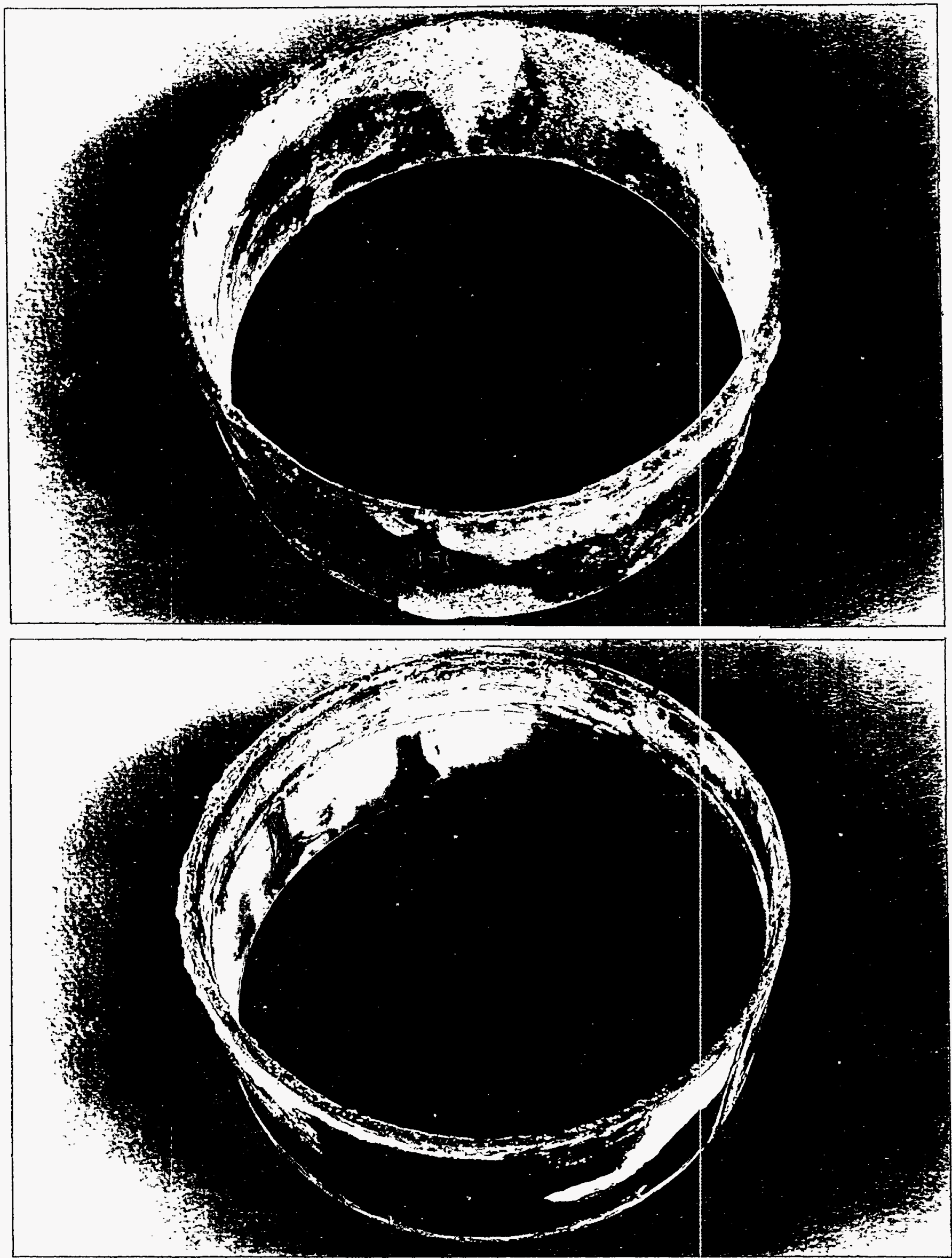

Figure 6. Condition of 049-11 (Coating C) (top) and 049-16 (Coating C) after first SCWO test. 
The following photographs (Figure 7) show the condition of 049-12 (Coating C) after 120 hours of testing. The coating had looked intact after the first 60 hours but then had delaminated. The other two rings in the same section (Section 2) were in the reactor for the second 60-hour test. Both 072-3 (Coating D) and 073-5 (Coating E) showed heavy blistering of the zirconia outer layer but the titania layer underneath was still intact. This would correspond to the behavior of 049-12 in the first 60-hour test. Similar rings were described as follows:

- 060-6 C No damage observed

- $\quad$ 072-2 D $\mathrm{ZrO}_{2}$ gone, significant loss of $\mathrm{TiO}_{2}$

- $072-4 \mathrm{D}$ Heavy blistering, $\mathrm{TiO}_{2}$ intact after 60 hours, coating half gone, flaking after 120 hours

- 073-6 E Heavy blistering, $\mathrm{TiO}_{2}$ intact after 60 hours, coating half gone, flaking after 120 hours

- 073-7 $\mathrm{E} \mathrm{ZrO}_{2}$ gone, $\mathrm{TiO}_{2}$ intact after 60 hours, cracked, chipped, and flaking after 120 hours. 

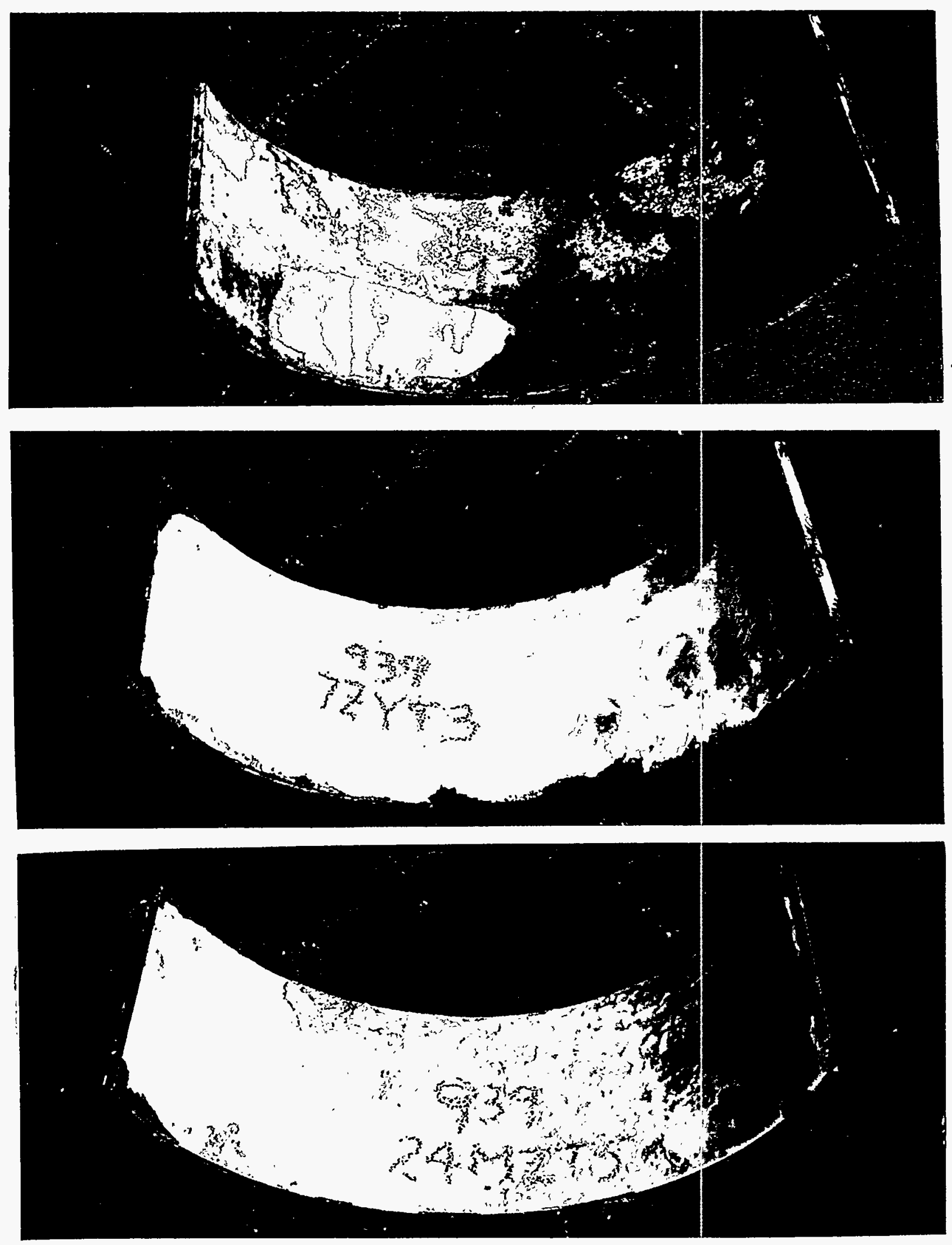

Figure 7. Condition of 049-12 (Coating C) (top), condition of 072-3 (Coating D) (middle), and condition of 073-5 (Coating E) after second SCWO test. 
The following photographs (Figures 8 and 9) show the condition of 060-5 (Coating C) from the second 60-hour test. 060-5 was in Section 1. There was some peeling of the titania layer in contrast to how 049-11 (Coating C) had behaved in Section 1 in the first 60-hour test. A similar ring (071-1 Coating C) from Section 4 showed a patch of delamination while 049-13 (Coating C) in Section 3 looked intact after 60 hours. There was no observable degradation after 120 hours, and after a total of 240 hours patches of the substrate were visible. The titania coating had either thinned or small sections had spalled off, when the patches of delamination occurred. Section 3 was considered the least harsh environment present and seem to allow Coating $C$ to survive long enough for either thinning or spalling to occur.

The one Type $\mathrm{C}$ coating on a titanium ring looked intact after 120 hours in Section 2 (082-1 coating $\left.C^{\prime}\right)$ though one bump was observed. 

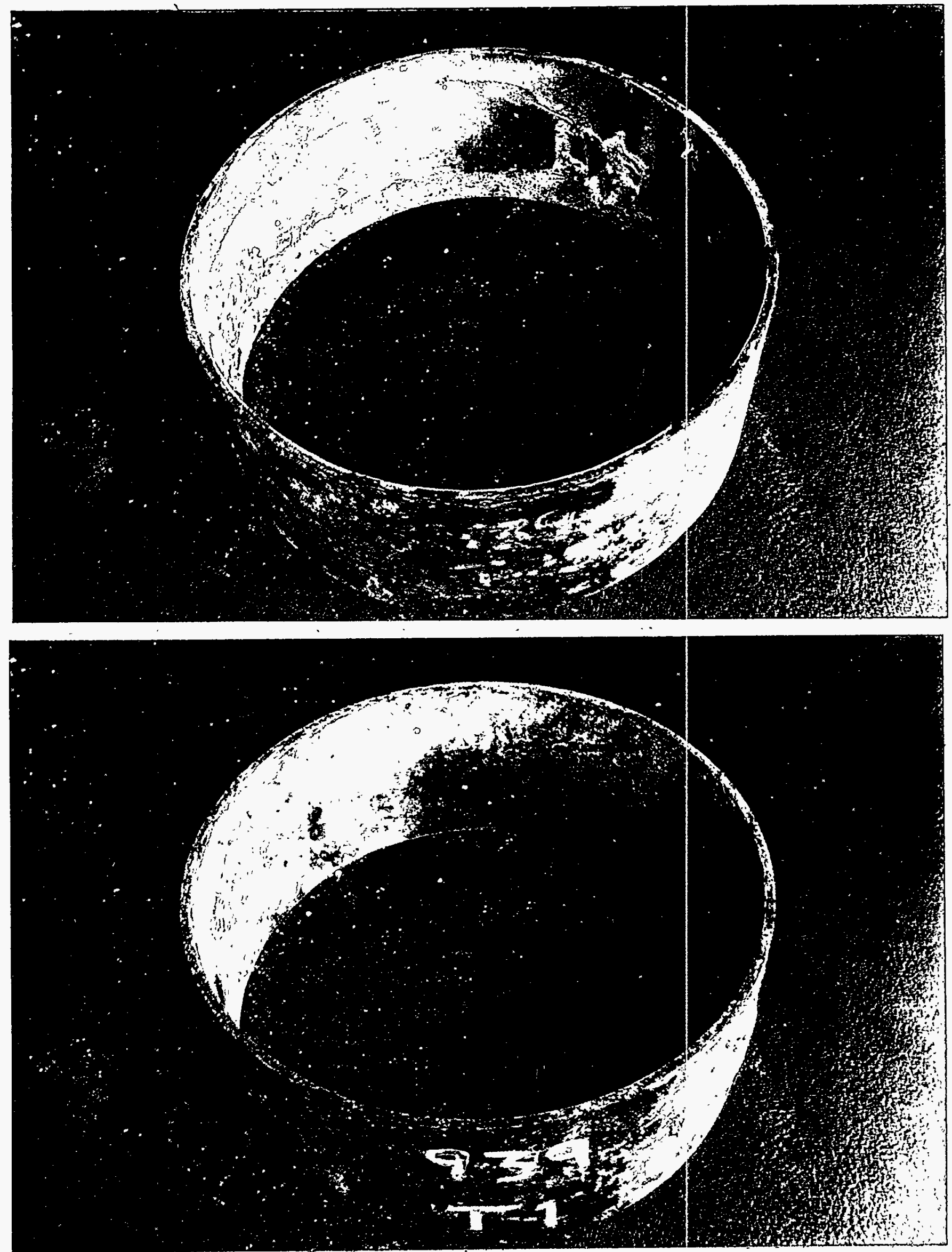

Figure 8. Condition of 060-5 (Coating C) and 071-1 (Coating C). 


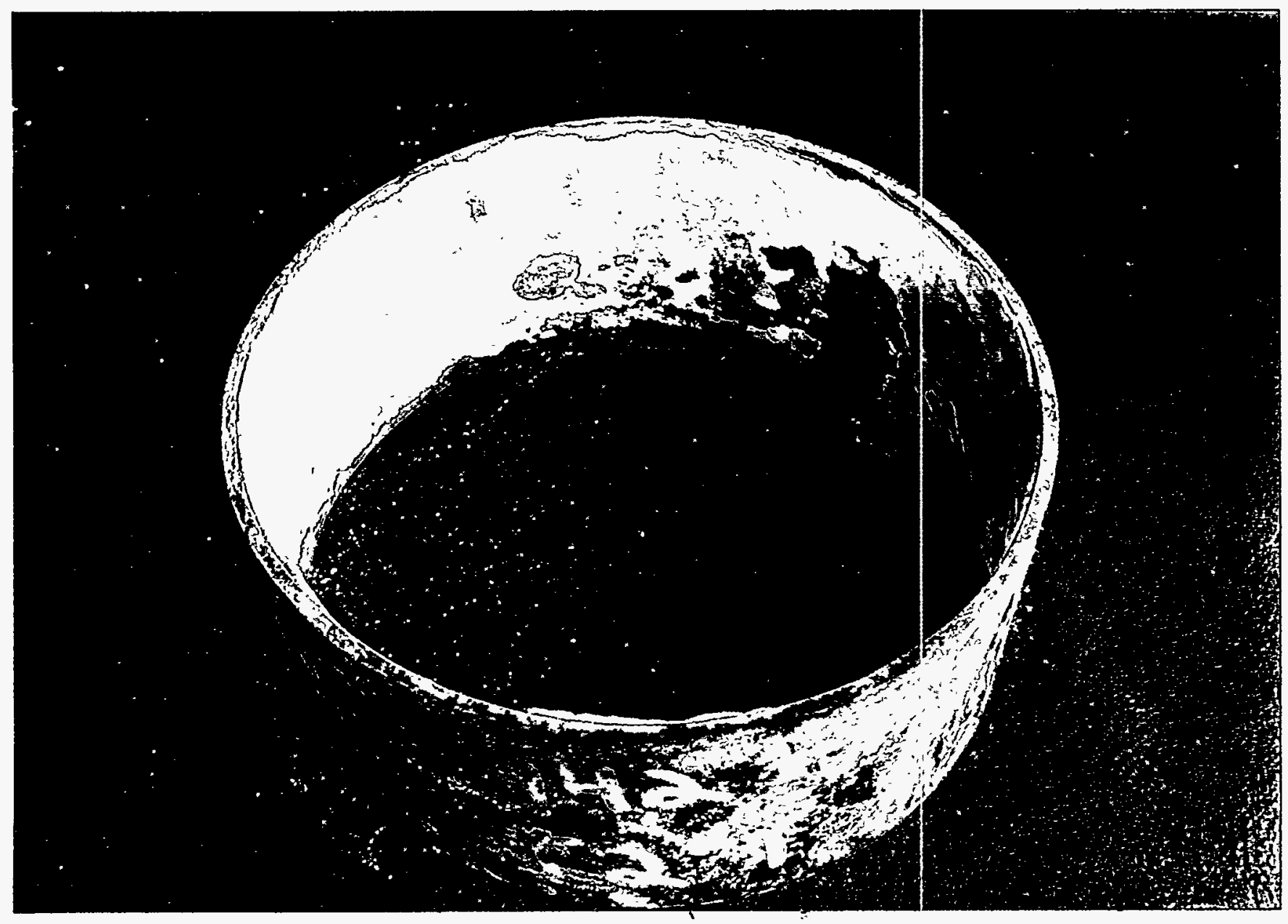

Figure 9. Condition of $082-1$ (Coating $\mathrm{C}$ ). $\mathrm{NiCrAl} / \mathrm{TiO}_{2}$ coating on titanium substrate after 108-hour exposure. 
The following photographs (Figures 10-12) show the Type F coatings. 083-4 was in good condition after 120 hours in Section 5 though it is hard to see the coating due to the salt deposition. Both 083-3 in Section 3 and 083-5 in Section 1 were also in good condition after 120 hours while $083-8$ in Section 5 shows delamination. The difference between $083-4$ and $083-8$ was that $083-8$ was on an Inconel 625 ring while the others were on a titanium ring. The same results were seen with 083-2 in Section 1 and 083-6 in Section 4, which were on titanium rings and did well, while 083-7 in Section 1 on an Inconel 625 ring was cracked, chipped, and flaking. 


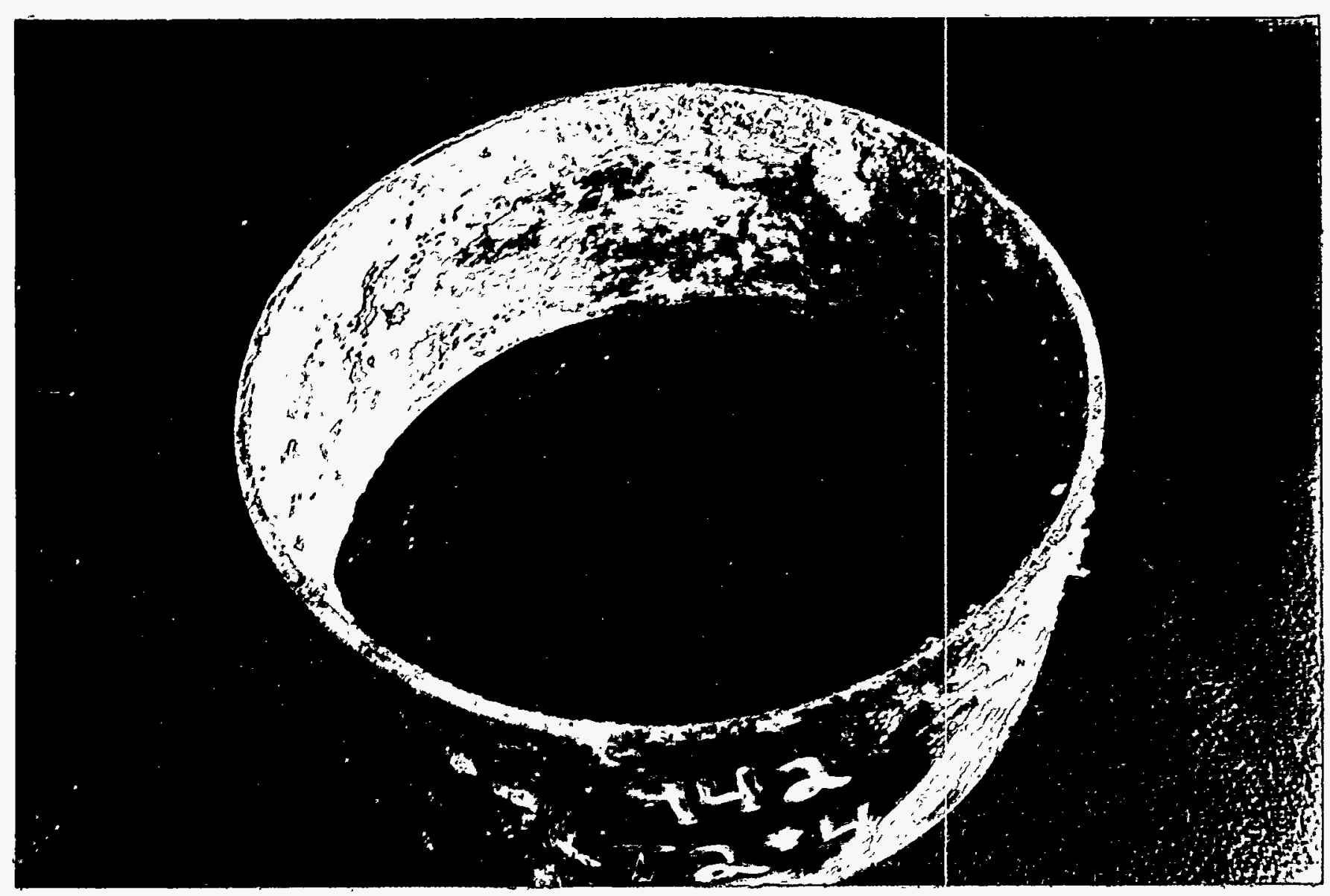

Figure 10. Condition of $083-4$ ( $\mathrm{F}$ Coating). Ti- $6 \mathrm{Al}-4 \mathrm{~V} / \mathrm{TiO}_{2}$ coating on titanium substrate intact after 108 hours of exposure in the bottom position of the reactor. 


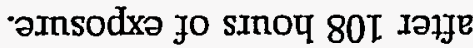

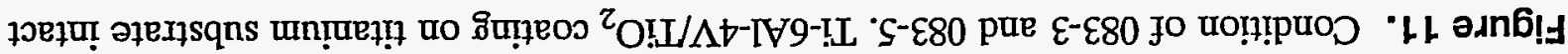

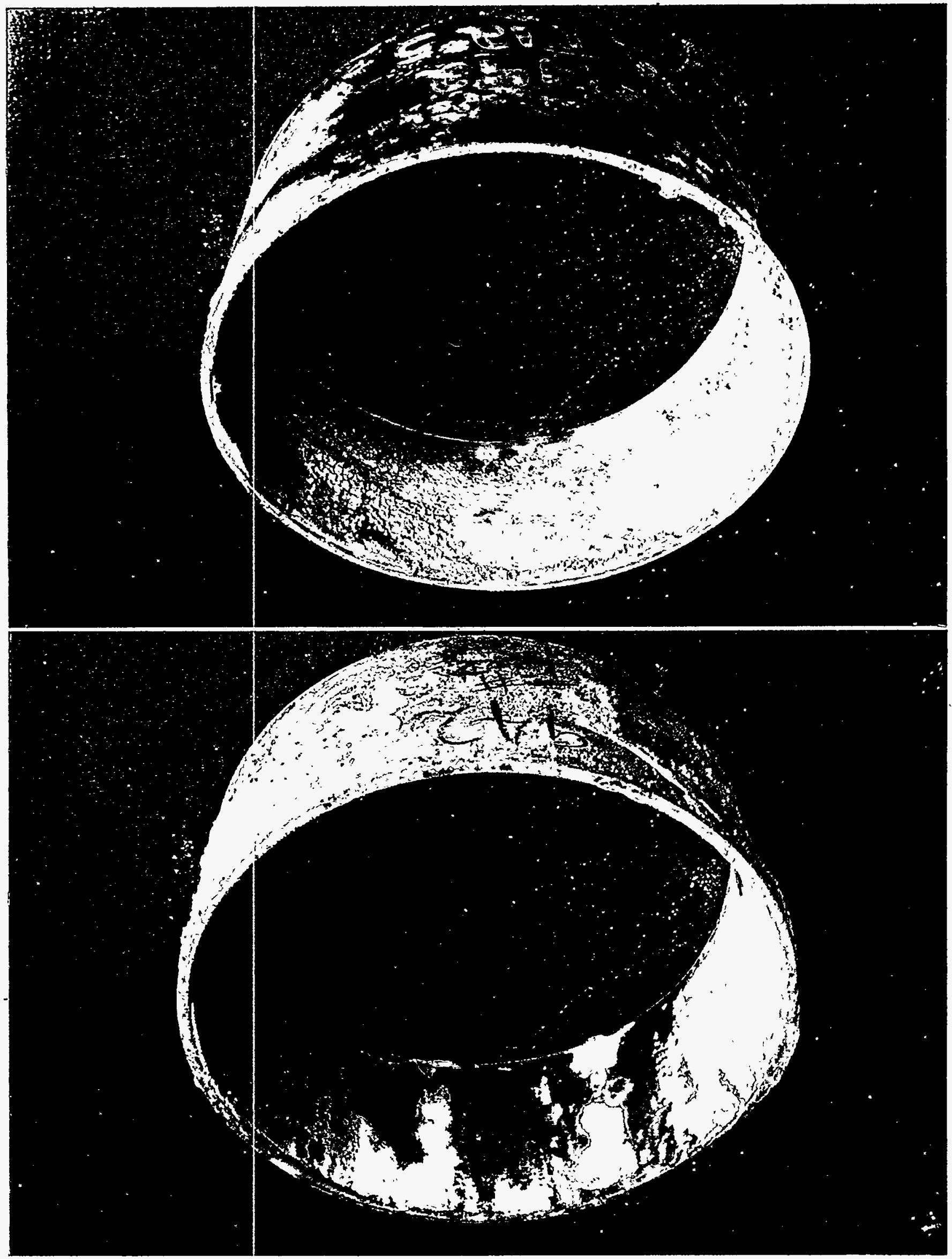




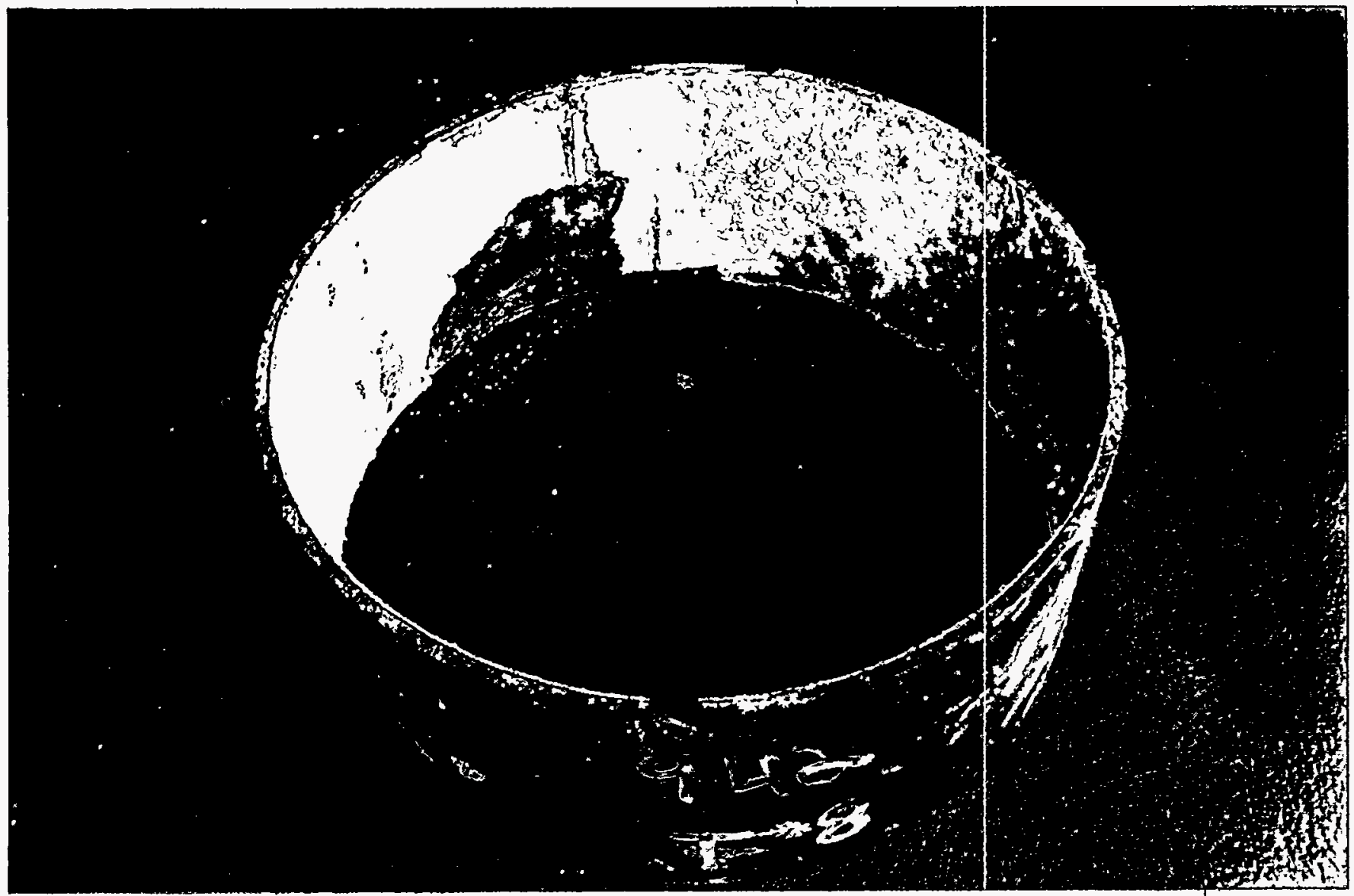

Figure 12. Condition of $083-8$. $\mathrm{Ti}-6 \mathrm{Al}-4 \mathrm{~V} / \mathrm{TiO}_{2}$ coating on $\mathrm{IN} 625$ ring showing lifting and spallation of the coating. 


\subsection{Experimental Alloys}

The following photographs (Figures 13 and 14) show the metal coupons from Section 1 and Section 5. An Inconel 625 coupon is shown in Section 1 for comparison, and a Hastelloy C-22 coupon is shown from Section 5 for comparison. The coupons were weighed after each run after being cleaned in accordance with ASTM procedure. The data are presented in Table 5.

Photographs were done with an optical stereomicroscope at $3 \times$ to $40 \times$ magnification. The results of the photographs showed dissolution and pitting to have been the corrosion mechanisms.

Table 4 is a summary of the total mils/year rate of corrosion. All commercial nickel alloy samples suffered severe corrosion with weight losses ranging between 14 and 30\% except for the C-276 in Section 1, which had a weight loss of $67 \%$ after the first 60 hours of testing. Some coupons were pulled after only a short period of testing due to severe pitting, while all the samples showed signs of pitting and crevice corrosion.

The experimental alloys in Section 5 were below the water line and saw a caustic environment instead of an acid environment. 


\section{Section 1}
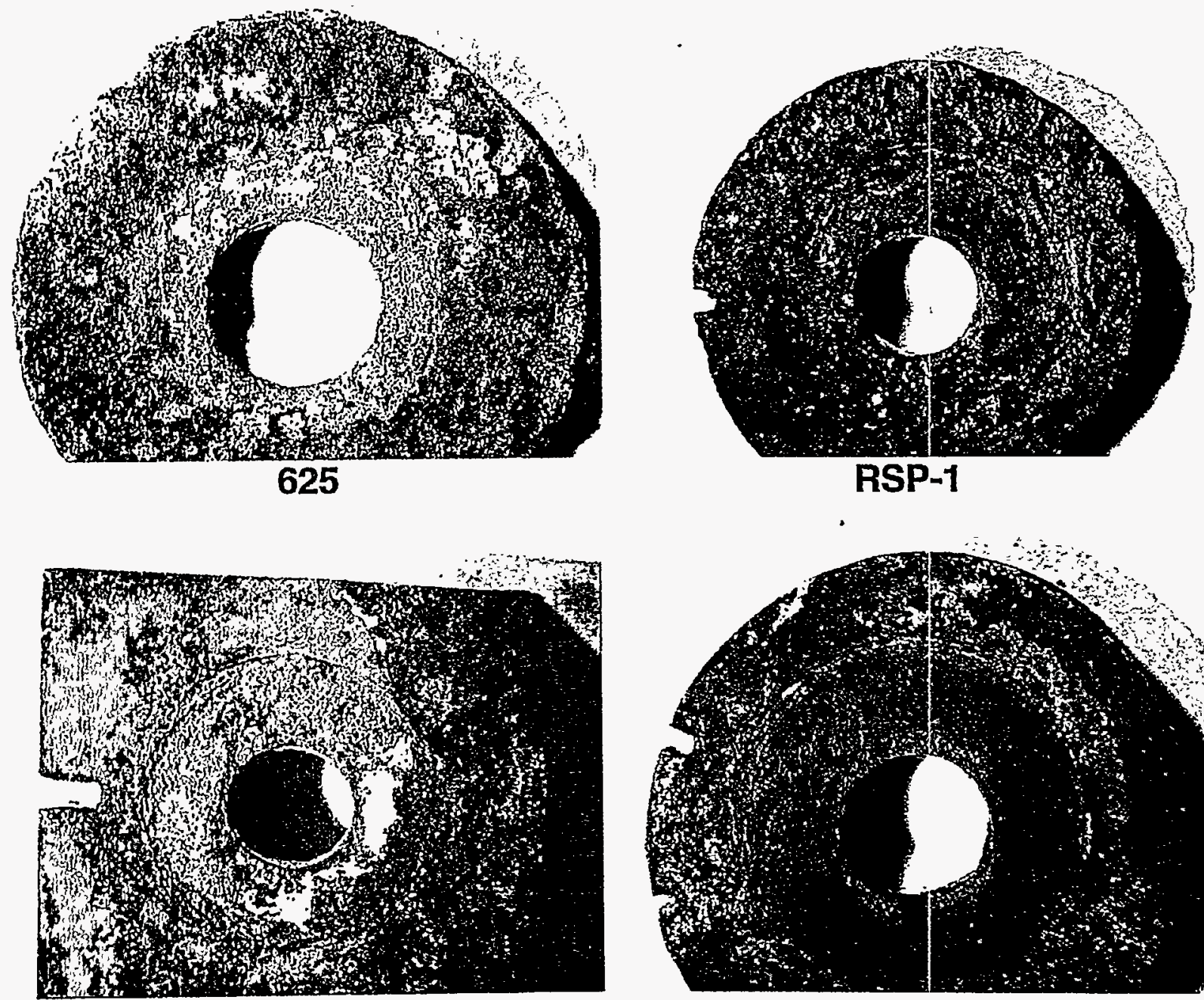

620
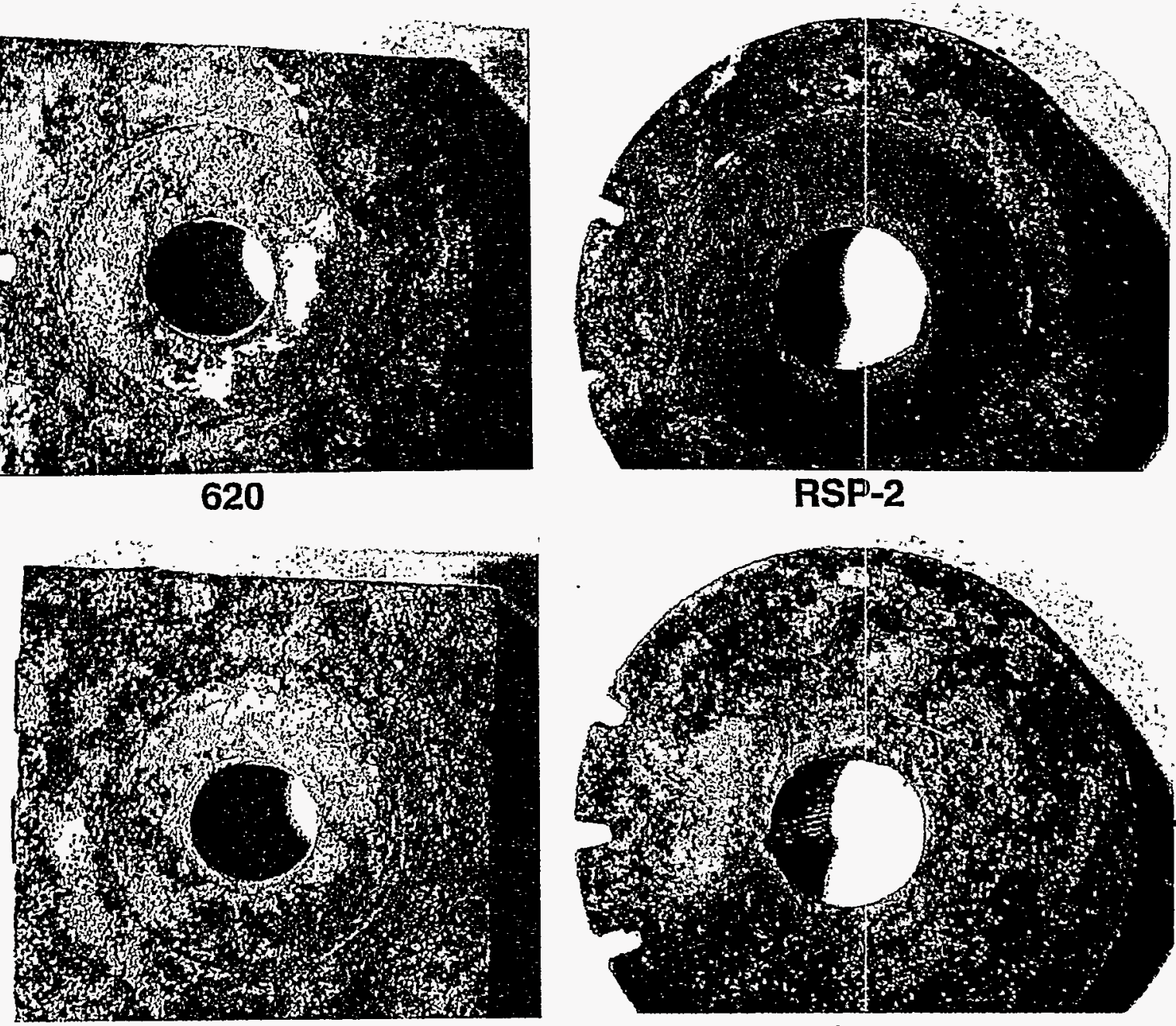

621

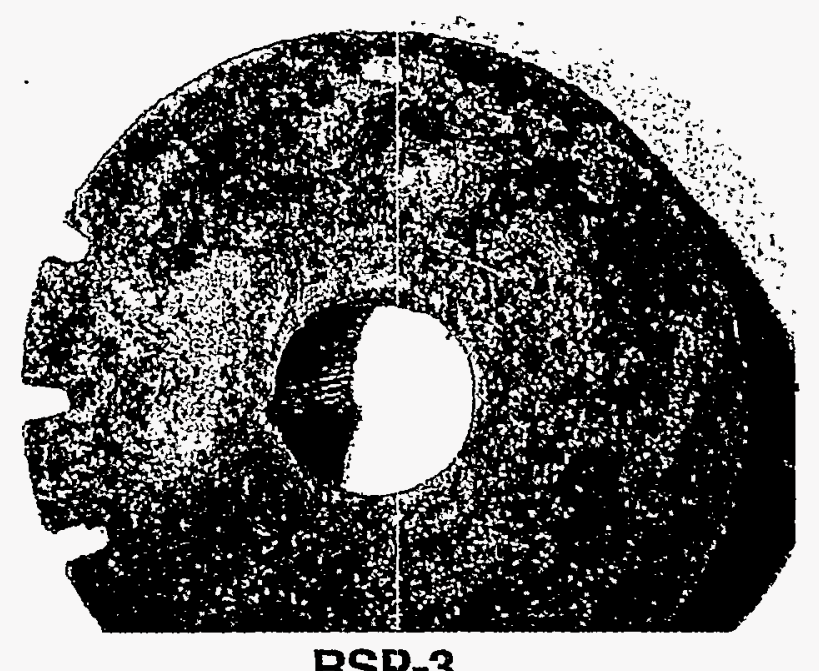

Figure 13. Metal coupons from Section 1. 

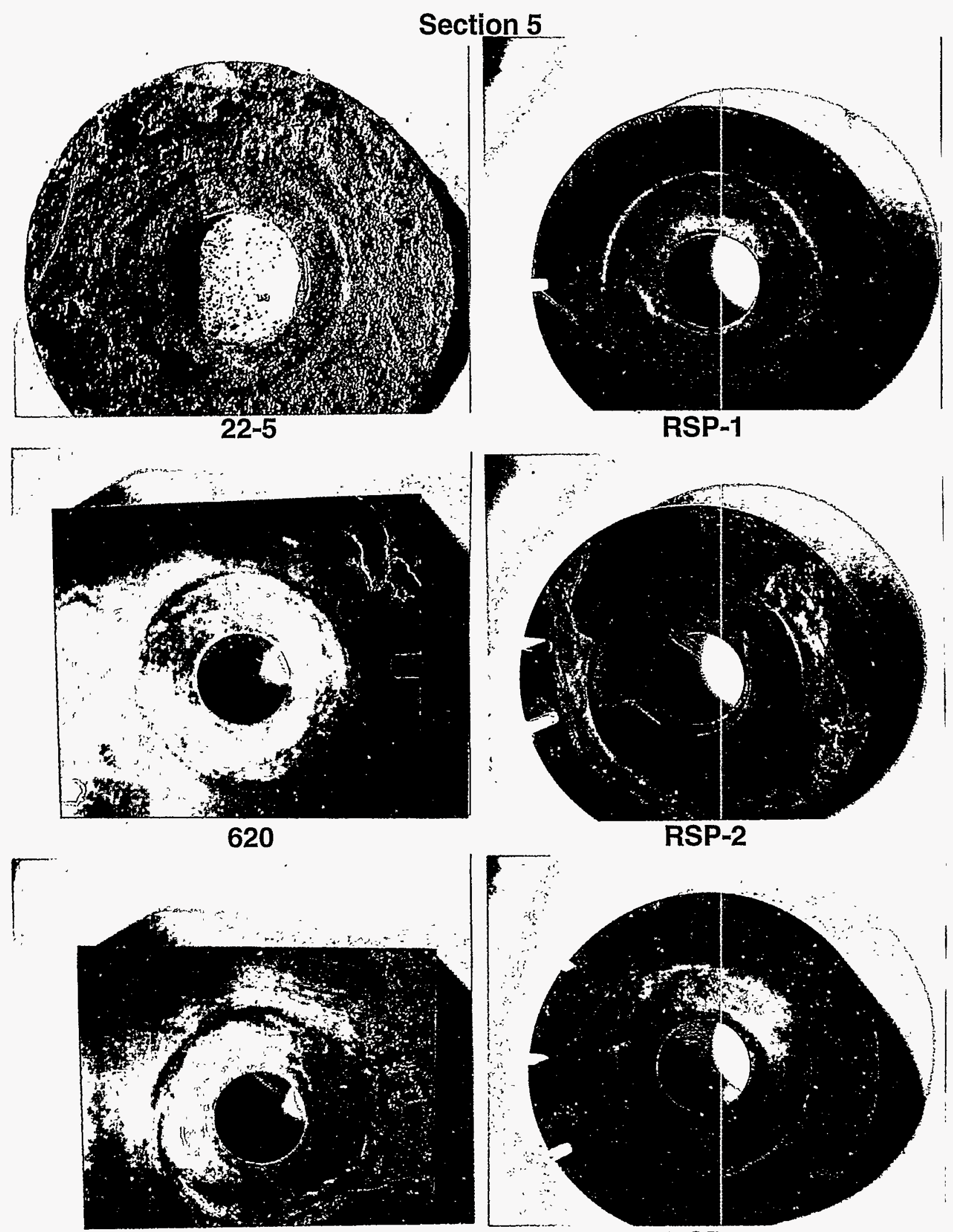

621

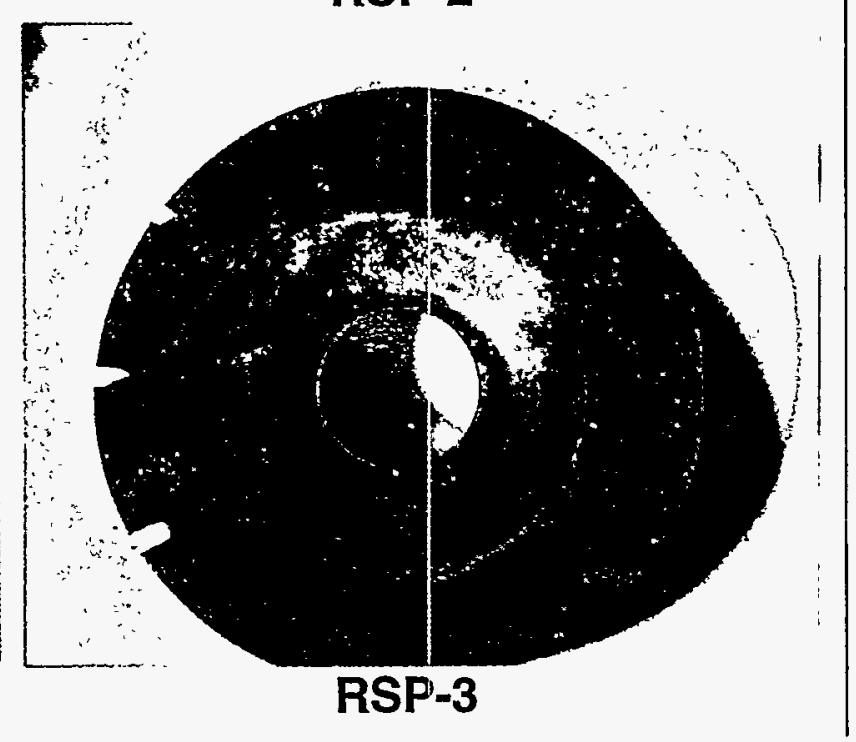

Figure 14. Metal coupons from Section 5. 
Table 4. Mils per year corrosion rate of the metal coupons.

\begin{tabular}{||l|c|c|c|c|c|c|c|c|c||}
\hline & 620 & 621 & RSP1 & RSP2 & RSP3 & 686 & C-276 & C-22 & I-625 \\
\hline Section 1 & 266 & 442 & 560 & 173 & 253 & 386 & 4,602 & 472 & 369 \\
\hline Section 2 & 410 & 327 & 678 & 288 & 231 & 491 & 882 & 498 & 477 \\
\hline Section 3 & 175 & 159 & 326 & 177 & 282 & 342 & 647 & 314 & 226 \\
\hline Section 4 & 254 & 273 & 323 & 954 & 1143 & 449 & 732 & 388 & 353 \\
\hline Section 5 & 0.6 & 0.6 & 5.3 & 2.2 & 14.6 & 258.3 & 483.7 & 270.4 & 546.6 \\
\hline \hline
\end{tabular}

Table 5. Shows the actual weight change in the metal coupons by section.

\begin{tabular}{|c|c|c|c|c|c|c|c|c|c|}
\hline & 620 & 621 & RSP-1 & $\mathrm{RSP}_{-2}$ & RSP-3 & 686 & C-276 & $C-22$ & $I-625$ \\
\hline \multicolumn{10}{|l|}{ Section 1} \\
\hline 0 hrs & & & $13.155 \mathrm{~g}$ & $13,466 \mathrm{~b}$ & $11.848 \mathrm{~g}$ & & $19.444 \mathrm{~g}$ & $19.266 \mathrm{~g}$ & $18.518 \mathrm{~g}$ \\
\hline 4 hrs & $35.6633 \mathrm{~g}$ & $34.0835 \mathrm{~g}$ & & H. & & $25.144 \mathrm{~g}$ & & & \\
\hline $60 \mathrm{hrs}$ & $35.174 \mathrm{~g}$ & $33.462 \mathrm{~g}$ & $12.299 \mathrm{~g}$ & $13,073 \mathrm{~g}$ & $11.413 \mathrm{~g}$ & $23.868 \mathrm{~g}$ & $6.389 \mathrm{~g}$ & $18.255 \mathrm{~g}$ & $17.551 \mathrm{~g}$ \\
\hline$\%$ Difference & $1 \%$ & $2 \%$ & $7 \%$ & ४४\% & $4 \%$ & $5 \%$ & $67 \%$ & $5 \%$ & $5 \%$ \\
\hline $120 \mathrm{hrs}$ & $33.776 \mathrm{~g}$ & $32.133 \mathrm{~g}$ & $11.465 \mathrm{~g}$ & $12801 \mathrm{~g}$ & $11.007 \mathrm{~g}$ & & & $16.797 \mathrm{~g}$ & $16.018 \mathrm{~g}$ \\
\hline$\%$ Difference & $3.97 \%$ & $3.97 \%$ & $6.78 \%$ & \% $208 \%$ & $3.56 \%$ & & & $7.99 \%$ & $8.73 \%$ \\
\hline $240 \mathrm{hrs}$ & $32.402 \mathrm{~g}$ & $28.671 \mathrm{~g}$ & $10.084 \mathrm{~g}$ & $12517 \mathrm{~g}$ & $10.461 \mathrm{~g}$ & & & $13.875 \mathrm{~g}$ & $14.379 \mathrm{~g}$ \\
\hline$\%$ Difference & $4.07 \%$ & $10.77 \%$ & $12.05 \%$ & $202 \%$ & $4.96 \%$ & & & $17.40 \%$ & $10.23 \%$ \\
\hline TOTAL & $9.14 \%$ & $15.88 \%$ & $23.34 \%$ & xyoso & $11.71 \%$ & & & $27.98 \%$ & $22.35 \%$ \\
\hline Section 2 & 620 & ঔ 621 & RSP-1 & RSP-2 & RSP-3 & 686 & $\mathrm{C}-276$ & $\mathrm{C}-22$ & $I-625$ \\
\hline 0 hrs & & अ. & $13.079 \mathrm{~g}$ & $12.904 \mathrm{~g}$ & $12.999 \mathrm{~g}$ & & $19.63 \mathrm{~g}$ & $19.113 \mathrm{~g}$ & $18.587 \mathrm{~g}$ \\
\hline $4 \mathrm{hrs}$ & $34.411 \mathrm{~g}$ & $337564 \mathrm{~g}$ & & & & $25.122 \mathrm{~g}$ & & & \\
\hline $60 \mathrm{hrs}$ & $33.081 \mathrm{~g}$ & \%22087g & $12.064 \mathrm{~g}$ & $12.536 \mathrm{~g}$ & $12.264 \mathrm{~g}$ & $23.582 \mathrm{~g}$ & $17.295 \mathrm{~g}$ & $17.659 \mathrm{~g}$ & $17.458 \mathrm{~g}$ \\
\hline$\%$ Difference & $4 \%$ & \% & $8 \%$ & $3 \%$ & $6 \%$ & $6 \%$ & $12 \%$ & $8 \%$ & $6 \%$ \\
\hline $120 \mathrm{hrs}$ & $31.492 \mathrm{~g}$ & $\% 31.475 \mathrm{~g}$ & $11.191 \mathrm{~g}$ & $12.041 \mathrm{~g}$ & $11.736 \mathrm{~g}$ & $21.665 \mathrm{~g}$ & $12.288 \mathrm{~g}$ & $15.822 \mathrm{~g}$ & $16.124 \mathrm{~g}$ \\
\hline$\%$ Difference & $4.80 \%$ & $\%$ & $7.24 \%$ & $3.95 \%$ & $4.31 \%$ & $8.13 \%$ & $28.95 \%$ & $10.40 \%$ & $7.64 \%$ \\
\hline $240 \mathrm{hrs}$ & $29.386 \mathrm{~g}$ & \% $29745 \mathrm{~g}$ & $9.352 \mathrm{~g}$ & $10.951 \mathrm{~g}$ & $10.995 \mathrm{~g}$ & $18.078 \mathrm{~g}$ & & $13.419 \mathrm{~g}$ & $13.237 \mathrm{~g}$ \\
\hline \% Difference & $6.69 \%$ & $2 \% 550 \%$ & $16.43 \%$ & $9.05 \%$ & $6.31 \%$ & $16.56 \mathrm{~g} \%$ & & $15.19 \%$ & $17.90 \%$ \\
\hline TOTAL & $14.60 \%$ & \%11 $88 \%$ & $28.50 \%$ & $15.13 \%$ & $15.42 \%$ & $28.04 \%$ & & $29.79 \%$ & $28.78 \%$ \\
\hline Section 3 & 620 & $\because \% 621$ & RSP-1 & RSP-2 & RSP-3 & 686 & $C-276$ & $\mathrm{C}-22$ & $\mathrm{I}-625$ \\
\hline $0 \mathrm{hrs}$ & & W\% : & $11.877 \mathrm{~g}$ & $12.911 \mathrm{~g}$ & $13.858 \mathrm{~g}$ & & $19.66 \mathrm{~g}$ & $19.083 \mathrm{~g}$ & $18.52 \mathrm{~g}$ \\
\hline
\end{tabular}




\begin{tabular}{|c|c|c|c|c|c|c|c|c|c|}
\hline & $\% 6 I^{\circ} 9 I$ & & $\% Z L^{\prime} \downarrow I$ & $\% 850$ & $\% 60^{\circ} 0$ & $\% I Z 0$ & $\% \varepsilon 0^{\circ} 0$ & \%200 & TVLOL \\
\hline & $\% 00^{\circ} 0 \mathrm{I}$ & & $\% \$ 6 L$ & $\% 00^{\circ} 0$ & $\% 20^{\circ} 0$ & $\% 20^{\circ} 0$ & $\% 00^{\circ}$ & $\% 00^{\circ} 0$ & әวนәдәџ! \\
\hline & 8 IL6SI & & \& $\angle 9 D^{\circ} I 2$ & \& $\angle 08^{\circ} E I$ & $8^{8}$ IL9*ยI & I SI9 ${ }^{\circ} \varepsilon I$ & $89 L 2: 62$ & 8 \&Z6 ${ }^{\circ}$ IE & sug $0+2$ \\
\hline & $\%\llcorner)^{\prime} \varepsilon$ & & $\% 80^{\circ} t$ & $\%<00$ & $\%+0^{\circ} 0$ & $\% 0^{\circ} 0$ & $\% 200$ & $\%$ \%00 & әэณәләд! \% \% \\
\hline & I 9DLLLI & & 马 ఒZE६乙 & \& L08'EI & \& †I9*EI & 8 8I9॰ EI & I SLZ 62 & 8 \& $\varepsilon 6^{\circ} \mathrm{TE}$ & suq OZI \\
\hline$\% 8$ & $\%$ & $\%$ & $\% \varepsilon$ & $\% I$ & $\% 0$ & $\% 0$ & $\% 0$ & $\% 0$ & әวนวгә! \\
\hline \multirow[t]{2}{*}{ 8 $6 L I L I$} & 8 8 $๑ 8 \varepsilon^{\circ} 8[$ & 8 I $66^{\circ} \mathrm{LI}$ & I STE & 8ิ 9L8' & 86 6I9 $8 I$ & 8 $\varsigma Z 9^{\circ} \varepsilon I$ & 8 โ8น" 62 & 8 LZ6 TE & sin 09 \\
\hline & & & \& ZLI'SZ & & & & $8+82: 62$ & $8 \varepsilon 6$ IE & salt \\
\hline $8999^{\circ} 81$ & \& $\angle S 0^{\circ} 6 I$ & 8 \&9ع 6I & & 8̊ $\angle 88^{\circ} \varepsilon I$ & 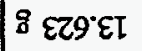 & $8+79^{\circ} \varepsilon I$ & & & ssq 0 \\
\hline$s Z 9-\mathrm{I}$ & z२-つ & $9 \angle \tau-J$ & 989 & $\varepsilon-d s \psi$ & $\tau-d S \&$ & I-dS\& & IZ9 & 029 & s tuọjors \\
\hline \%โยIZ & $\% 88^{\circ} \mathrm{ZZ}$ & \%It十t & $\%$ & $\% S 56 t$ & $\% 25 \triangleright \varepsilon$ & $\% 89^{\circ} \mathrm{ZI}$ & $\% 98^{\circ} 0 \mathrm{I}$ & $9156=$ & TVIOI \\
\hline$\% 90^{\circ} S I$ & $\% \$ 69 \mathrm{~L}$ & $\% 80^{\circ} 8 \varepsilon$ & $\% 00^{\circ} 6 \mathrm{I}$ & $\% 0 t 0 t$ & $\%$ I8 LZ & $\% \varepsilon L ' S$ & $\%<t=9$ & 0699 & әэиวләщ! \% \\
\hline $8200^{\circ} \mathrm{tI}$ & 8 I99*t & $890 L^{\circ} \mathrm{OI}$ & $8668^{\circ} 8 \mathrm{I}$ & 86689 & 8 \&S6 6 & \& LEZZI & \& L6t'LZ & $12656 \%$ & sst $0 \nmid z$ \\
\hline$\% 99^{\circ}$ & $\% 0 L^{\circ} S$ & \%25 & $\% 98^{\circ}$ & \%ZZZI & $\%$ It゙9 & $\%<8^{\circ} \rightarrow$ & $\% 99^{\circ} \varepsilon$ & $\%+0)$ & әวนวдәң! \% \\
\hline $8 I 6 I^{\circ} L I$ & \& $\varepsilon S 9^{\circ} L I$ & $8682 \mathrm{LI}$ & 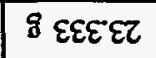 & \& $L E L O I$ & \$ L8LEEI & 8 I86ZI & $86 \sigma \varepsilon 6 \tau$ & 867018 & SXY OZI \\
\hline$\% 2$ & $\% \tau$ & $\% 5$ & $\% \varepsilon$ & $\%$ & $\% \varepsilon$ & $\% \varepsilon$ & $\%$ L & $\% 1$ & วันวдәщ! \% \\
\hline \multirow[t]{2}{*}{ 8 zZZ• 81} & $8 \mathrm{Zl} 8 \mathrm{I}$ & $8 \varepsilon 8[$ & g $s z S+z$ & 8 ZहZZI & 8 IEL'tI & I $959^{\circ} \varepsilon I$ & 8 9ISOE & 968628 & sut 09 \\
\hline & & & $89 \sqcup \varepsilon \Omega$ & & & & 8 $29+8^{\circ} 0 \varepsilon$ & 6 ecofze & ssq t \\
\hline 895581 & $810^{\circ} 6 I$ & 885261 & & 8 \$89?I & $8 \tau S I$ & $8+I 0^{\circ}+I$ & & 19.1 & sयt 0 \\
\hline SZ9-I & $22-0$ & $9 L 2-3$ & 989 & $\varepsilon$-dS\& & $\tau-d s d$ & I-JSY & IZ9 & 089 & $\downarrow$ tuonjoas \\
\hline$\% \$ \$ 9$ & \%Itナ8 & $\% E S L Z$ & \%ऽЕ 6I & \%9I'II & \%عSL & $\% 80^{\circ}$ SI & 26919 & \%LE9 & TVIOI \\
\hline$\% \angle 9^{\circ} L$ & $\%$ \% II & & \%कI:6 & $\% 827$ & \%t0"t & \%SE 8 & $\% \varepsilon \varepsilon \varepsilon=1$ & 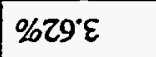 & әэณวләш! $\%$ \\
\hline $886 \mathrm{SI}$ & $866^{\prime} S I$ & & \& $\angle 80^{\circ} 02$ & 8 IIEZI & $86 \varepsilon 6 \mathrm{II}$ & $8980^{\circ} 0 \mathrm{I}$ & $3 \mathrm{eg} / \mathrm{\sigma}$ & 8 LLSLE & sug $0+2$ \\
\hline$\% 6 \tau \varepsilon$ & $\% \pitchfork S^{\circ}$ & $\% 6 t^{\circ} 0 z$ & \%E9"9 & $\% 6 Z Z$ & $\% \mathrm{SOZ}^{2}$ & $\% 05$ & 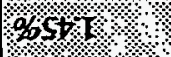 & $\% 95 I$ & әэцәгәп! \% \\
\hline \& $\angle O E \angle L$ & 8 $8 L t^{\circ} L I$ & $8^{8} \angle t Z C^{\circ} I I$ & $8 \mathrm{LtSZZ}$ & 8 L98ZI & \& $20 t+2 I$ & I SOO'II & $3 \mathrm{E1800}$ & 8 ว9८乙ะ & SIq OZI \\
\hline$\% \varepsilon$ & $\%$ & $\% 6$ & $\%$ & $\% S$ & $\% \tau$ & $\% \varepsilon$ & 261. & $\% I$ & әэшวدәд! \% \% \\
\hline \multirow[t]{2}{*}{8 S68LI } & 8 IE8I & $8816 \mathrm{LI}$ & $8 \angle D I^{\circ}+2$ & 8 Z9I'EI & I عOL"ZI & 8 EZSII & Os92:IE & ร โ8น દะ & ड्य 09 \\
\hline & & & $8 \mathrm{zot} s 2$ & & & & 991918 & I SSCL'EE & SIप t \\
\hline SZ9-I & $z \tau=\supset$ & $9 \angle Z-J$ & 989 & $\varepsilon-d S \&$ & ZASd & I-dSQ & IZ9 & 029 & \\
\hline
\end{tabular}




\section{DATA ANALYSIS}

\subsection{Analysis of Performance by Section}

The analysis of the ceramic rings and metal coupons was first done by comparing the . performance by sections. The chemical environment of each section was described by the pressure, temperature, $\mathrm{pH}$, and presence of particular compounds. Discussions of $\mathrm{pH}$ are dependent on assumptions of atmosphere and temperature. When $\mathrm{pH}$ is referred to at supercritical conditions, it implies the $\mathrm{pH}$ of the corresponding cooled liquid. When $\mathrm{HCl}$ is at supercritical conditions it is actually molecular $\mathrm{HCl}$ gas and not ionized so the amount of hydrogen ions at the surface of the metal is quite reduced. It is only when the temperature is brought down that the acid forms and dissolves in the water, causing a significant increase in the amount of hydrogen ions present at the surface.

Coating A was the basic design with the nickel/chrome/alumina bond coat, then a transition coat of nickel/chrome/alumina/7\% partially stabilized zirconia/yttria (7\% YZ). The top coat was 7\% YZ chosen because previous corrosion tests have shown good performance of zirconia in SCWO environments. ${ }^{d}$ For Coating $B$ an additional alumina interlayer was added beneath the $7 \% \mathrm{YZ}$.

Coating $\mathrm{C}$ used the same bond coat as Coatings $\mathrm{A}$ and $\mathrm{B}$ but had a transition layer of nickel/chrome/alumina/titania and a top coat of titania. Coating $\mathrm{D}$ was the same as Coating $\mathrm{C}$ but with an added top layer of $7 \% \mathrm{YZ}$. Coating $\mathrm{E}$ was again the same as Coating $\mathrm{C}$ but with an added top layer of $24 \% \mathrm{MgZ}$.

Coating $\mathrm{F}$ was a complete titania/titanium system on a titanium ring. The bond coat was titanium/alumina/vanadium, the transition coat was titanium/alumina/vanadium/titania, and the top coat was titania. Coating $\mathrm{F}^{\prime}$ was the same except the substrate was Inconel 625.

\subsubsection{Section 1 Environment-Temperature $650^{\circ} \mathrm{C}, \mathrm{pH}$ of 0.8}

In Section 1 of the corrosion test, the temperature was $650^{\circ} \mathrm{C}$ and all fluids were in a supercritical phase. The feed included $350 \mathrm{~L} / \mathrm{min}$ of oxygen, $9,000 \mathrm{ppm}$ of chloride, and $900 \mathrm{ppm}$ of sulfate. Both acids and salts form in this section with the salts depositing onto the ceramic walls and coupon tree.

\subsubsection{Ceramic Coupon Analysis.}

First 60-hour test: $\quad$ Rings: 047-1 (Coating A), 048-6 (Coating B), 049-11 (Coating C).

Second 60-hour test: Rings: 060-5 (Coating C), 058-1 (Coating A), 059-3 (Coating B).

120-hour test: $\quad$ Rings: $083-5$ (Coating F), 083-2 (Coating F), 083-7 (Coating F').

d. Telephone conversation with Mike Spritzer, General Atomics. 
These nine rings were at the highest temperature of the test. In the first 60 -hour test, the two rings with the zirconia top layer (047-1 and 048-6) both showed blistering, peeling, and edge chipping. The ring coated with the titania top coat (049-11) did not show any defects. The two rings with the zirconia top layer (059-3 and 058-1) delaminated in the second 60-hour test. The ring coated with titania (060-5) showed some peeling of the top coat. In the 120-hour test the two rings that were titania sprayed onto titanium (083-2 and 083-5) showed no defects while the one ring that was titania sprayed onto Inconel 625 substrate (083-7) showed cracking, chipping, and spalling. An indepth analysis of Ring 047-1 is presented in Section 8.3.

\subsubsection{Metal Coupon Analysis. ${ }^{\mathrm{e}}$}

The experimental nickel alloys of Section 1:

- The 620 coupon had general corrosion over $80 \%$ of the exposed surface and crevice corrosion. The depth of attack was up to 8 mils.

- The 621 coupon had general albeit not quite uniform attack virtually over the entire surface.

- $\quad$ RSP1 had severe corrosion up to 12 mils.

- $\quad$ RSP2 had relatively minor crevice corrosion with attack up to 3 mils.

- $\quad$ RSP3 was similar to RSP2 but had attack up to 6 mils.

The baseline nickel alloys of Section 1:

- Alloy 686 was heavily pitted after the first 60 -hour test. The pits were up to 8 mils deep.

- Alloy C-276 had severe corrosion after the first 60-hour test with numerous overlapping pits.

- Alloy C-22 also had severe corrosion with overlapping pits with depths up to 20 mils.

- Alloy 625 also had severe corrosion with some crevice attack near the hole of about 45 mils.

d. Vladimir Zilberstein, Effect of TrimSol Based SCWO Environment on Materials Tested in the MODAR Pilot Plant Vessel, Stone and Webster, September 1994. 


\subsubsection{Section 2 Environment-Temperature $600^{\circ} \mathrm{C}, \mathrm{pH}$ of 0.8}

\subsubsection{Ceramic Coupon Analysis.}

First 60-hour test: 047-2 (A), 048-7 (B), 049-12 (C).

Second 60-hour test: 072-2 (D), 073-5 (E), 049-12 (C).

120-hour test: $082-1\left(C^{\prime}\right), 072-2(D), 059-4(B)$.

In the first 60-hour test the two rings with a zirconia top layer (047-2 and 048-7) showed blistering, peeling, and chipping. Ring 048-7 also had delamination at the boundary between the alumina layer and the zirconia top layer. The titania coated coupon (049-12) showed no defects. In the second 60-hour test the rings coated with a layer of titania and then zirconia (072-2, 073-5) had heavy blistering of the zirconia with the titania intact after 60 hours but after an additional 120 hours the zirconia was gone and there was significant loss of the titania (072-2). The two rings coated with titania were both exposed for 120 hours. 049-12 looked good after 60 hours but was delaminating after 120 hours, while 082-1 still looked good after 120 hours. The difference between these two was that 082-1 was titania sprayed onto a titanium ring though it still had the nickel/chrome/aluminum bond coat. Coupon 059-4 (zirconia top coat) was exposed for 120 hours in Section 2 after being exposed for 60 hours in Section 5. This exposure resulted in heavy delamination.

\subsubsection{Metal Coupon Analysis.}

The experimental nickel alloys of Section 2:

- The 620 coupon had fairly severe corrosion while 621 had pronounced crevice corrosion with attack up to 10 mils.

- RSP1 had severe corrosion attack while RSP2 and RSP3 had an attack of dissolution.

The baseline nickel alloys of Section 2:

- Alloy 686 was severely corroded with pits between 15 to 30 mils.

- Alloy 625 had deep crevice attack up to 16 mils along with severe corrosion.

- $\quad$ Alloy C-22 had severe corrosion similar to Alloy 686 .

- Alloy C-276 was removed after 120 hours due to drastic thinning and major corrosion.

e. Vladimir Zilberstein, Effect of TrimSol Based SCWO Environment on Materials Tested in the MODAR Pilot Plant Vessel, Stone and Webster, September 1994. 


\subsubsection{Section 3 Environment-Temperature $500^{\circ} \mathrm{C}$, pH of 0.8}

\subsubsection{Ceramic Coupon Analysis.}

First 60-hour test: 047-3 (A), 048-8 (B), 049-13 (C).

Second 60-hour test: 072-3 (D), 073-6 (E), 049-13 (C).

120-hour test: 083-3 (F), 073-6 (E), 049-13 (C).

This section was considered the most mild environment of the five sections and yet the results of the zirconia coated rings were very similar to Section 2. In the first 60 hour test, 047-3 and 048-8 showed blistering and chipping in the second 60-hour test. 072-3 and 073-6 had heavy blistering of the zirconia with the titania intact after 60 hours but after an additional 120 hours the zirconia was gone and there was significant loss of the titania (073-6). The ring coated with titania on the nickel chrome bond coat (049-13) lasted the length of all three tests (240 hours) although patches of base metal were exposed. The ring coated with titania on a titania bond coat and titania ring (083-3) did very well after 120 hours.

\subsubsection{Metal Coupon Analysis. ${ }^{\mathrm{f}}$}

The experimental nickel alloys of Section 3:

- The 620 and 621 coupons had pronounced crevice corrosion with the crevice depth in 620 up to 12 mils near the edge.

- RSP1 also had crevice corrosion up to 10 mils while RSP2 had patchy dissolution up to 6 mils and RSP3 had uniform corrosion attack.

The baseline nickel alloys of Section 3:

- Alloy 686 had deep corrosion attack up to 15 mils.

- Alloy C-22 had severe corrosion attack up to 18 mils.

- Alloy 625 had isolated pits and areas of overlapping pits.

- Alloy C-276 was removed after 120 hours due to major corrosion.

f. Vladimir Zilberstein, Effect of TrimSol Based SCWO Environment on Materials Tested in the MODAR Pilot Plant Vessel, Stone and Webster, September 1994. 


\subsubsection{Section 4 Environment-Temperature $400^{\circ} \mathrm{C}$, pH of 1.5}

\subsubsection{Ceramic Coupon Analysis.}

First 60-hour test: 047-4 (A), 048-9 (B), 049-14 (C).

Second 60-hour test: 072-4 (D), 073-7 (E), 071-1 (C).

120-hour test: 072-4 (D), 073-7 (E), 083-6 (F).

This section had the added variable of the dilution stream coming in and spraying directly onto the rings. One of the zirconia rings (047-4) appeared to do well after the first test while the zirconia with the alumina interlayer showed cracks, blistering and some delamination. The zirconia over the titania layer (072-4 and 073-7) showed heavy blistering of the zirconia after 60 hours. One of the titania coated rings with the nickel/chrome bond (049-14) suffered from edge attack that corroded the base metal of Inconel 625 after only 60 hours, while another similar ring (071-1) did very well except for a patch of delamination that could have been due to the quench water hitting the ring. The titania coated ring with the titania bond on the titania ring (083-6) did well with some possible thinning of the coating.

\subsubsection{Metal Coupon Analysis.g}

The experimental nickel alloys of Section 4:

- The 620 metal coupon had severe corrosion with losses up to 16 mils, while the 621 coupon had losses up to 20 mils.

- The RSP1 coupon had losses of 8 mils, RSP2 had losses of 45 mils, and RSP3 was described as having major wastage.

The baseline nickel alloys of Section 4:

- Alloy 686 had deep corrosion attack up to 18 mils.

- Alloy C-22 had severe corrosion.

- Alloy C-276 had major corrosion up to 30 mils.

- Alloy 625 uniform corrosion with an average depth of attack of 12 mils with one pit with 30 mils depth.

g. Vladimir Zilberstein, Effect of TrimSol Based SCWO Environment on Materials Tested in the MODAR pilot Plant Vessel, Stone and Webster, September 1994. 


\subsubsection{Section 5 Environment-Temperature $300^{\circ} \mathrm{C}$, pH of 1.5}

\subsubsection{Ceramic Coupon Analysis.}

First 60-hour test: 047-5 (A), 048-10 (B), 049-16 (C).

Second 60-hour test: 060-6 (C), 058-2 (A), 059-4 (B).

120-hour test: 083-8 (F'), 060-6 (C), 083-4 (F).

This section saw the transition from the supercritical phase and the formation of acids. The water level was apparent by the water line mark on the bottom ring. While the zirconia again showed blistering and delamination (047-5, 048-10, 058-2, and 059-4), the five titania coated rings had a variety of results dependent on their bond coats and ring material. 049-16, 060-6, and 083-4 did well while 083-8 suffered from delamination. The difference is that $083-8$ had a titania bond coat on a Inconel 625 ring while the other three rings had bond coats that matched their rings. An in-depth Analysis of coupons 048-10 and 083-4 is presented in Section 8.3.

\subsubsection{Metal Coupon Analysis. ${ }^{\mathrm{h}}$}

The liquid level of the brine immersed the experimental nickels. The corrosion rates and descriptions do not reflect the performance in the severe environment of Section 5 but the performance in a brine solution.

The experimental nickel alloys of Section 5:

- The 620 coupon showed no signs of corrosion and 621 had minor attack.

- The RSP1 showed numerous small pits around the outer edge of the sample with crevice corrosion appearing likely to start.

- The RSP2 coupon showed no apparent signs of corrosion except for discoloration, while RSP3 had multiple deep pits and initial stages of crevice corrosion.

The baseline nickel alloys of Section 5:

- Alloy 686 had corrosion with a depth of attack of 3 to 8 mils along with a few deep pits up to 18 mils.

- Alloy C-22 had severe corrosion resulting from overlapping pits with some pits having up to 20 mils depth.

h. Vladimir Zilberstein, Effect of TrimSol Based SCWO Environment on Materials Tested in the MODAR Pilot Plant Vessel, Stone and Webster, September 1994. 
- Alloy 625 was removed after 60 hours due to severe corrosion

- Alloy C-276 was removed after 60 hours due to numerous pits up to 25 mils deep.

\subsection{Analysis of Performance by Material}

This subsection includes a comparison of performance of each material throughout all five sections:

- Coating A - 047-1, 047-2, 047-3, 047-4, 047-5, 058-1, 058-2

- Regardless of the section these rings were placed in, or the amount of thermal cycles they received, there was blistering or delamination after 60 hours of operation. The delamination is shown in Figure 25.

- Coating B - 048-6, 048-7, 048-8, 048-9, 048-10, 059-3, 059-4

- These rings also showed blistering or,delamination. The delamination occurred at the alumina layer.

- Coating C - 049-11, 049-12, 049-13, 049-14, 049-16, 060-5, 060-6, 071-1

- These rings suffered from an edge attack, which given greater than 60 hours would result in delamination. The rings that did not have edge attack showed a thinning of the top coat. Ring 049-13 had sections of the Inconel exposed after 240 hours.

- Coating D - 072-2, 072-3, 072-4

- These rings showed blistering of the top coat after 60 hours. After 60 hours the titania layer began to wear away.

- $\quad$ Coating E - 073-5, 073-6, 073-7

- These rings also showed blistering and in some cases the top layer was already gone by the 60 -hour run. The titania layer was intact after 60 hours but then began to be worn away.

- Coating $C^{\prime}-082-1$

- This coating was done on a titanium ring, and remained intact after 120 hours.

- Coating F - 083-2, 083-3, 083-4, 083-5, 083-6

- These rings performed the best with all five of them looking intact upon visual examination after 120 hours. 
- Coating $F^{\prime}$ - 083-7, 083-8

- These rings were Inconel 625 and both delaminated at the bond coat substrate interface.

\subsection{Analysis of Delamination Mechanisms}

\subsubsection{Coating 047-1}

An overall view of a failed coating (047-1) which shows the major coating spall between the bond layer and the intermediate blended layer is shown in Figure 15. A diagram of the failure mechanism is illustrated in Figure 26. Figures 16 and 17 show areas that were analyzed by the EDS technique. Table 6 documents the results. A description follows:

Areas 1,5,9 This area has the basic chemistry of the ceramic top coat of the Coating A with a slight difference in the yttria concentration.

Area 2,3 These areas are composed of products of the reaction of the surrogate containing supercritical fluid and the ceramic coating. The formation of these surrogate containing second phases has implications as the radionuclides and hazardous elements from a mixed waste stream could be concentrated in a coating that they react with.

Area 6 This area is a nickel sulfide $\left(\mathrm{NiS}_{2}\right.$ or $\left.\mathrm{Ni}_{3} \mathrm{~S}_{4}\right)$ reaction product.

Area 7 This area is a mixture of coating elements and waste/surrogate elements.

Area 8 The chemical analysis of this area chemistry only shows the elements present in the metallic bond coat.

Area 10 This area is rich in nickel and chrome, low in aluminum with silicon and iron present.

Area 11 This area appears to be yttria stabilized zirconia

Area 12,13 These areas are complex oxides with small amounts of TrimSol components such as sulfur.

Area 14 This area appears to be a nickel oxide with a small amount of sulfur present.

Area 15 This area shows the bond coat $(\mathrm{Ni}, \mathrm{Cr}, \mathrm{Al})$ chemistry. (The nominal chemistry of the prealloyed powder is Ni-balance, $\mathrm{Cr}-19 \%, \mathrm{Al}-6 \%)$. 


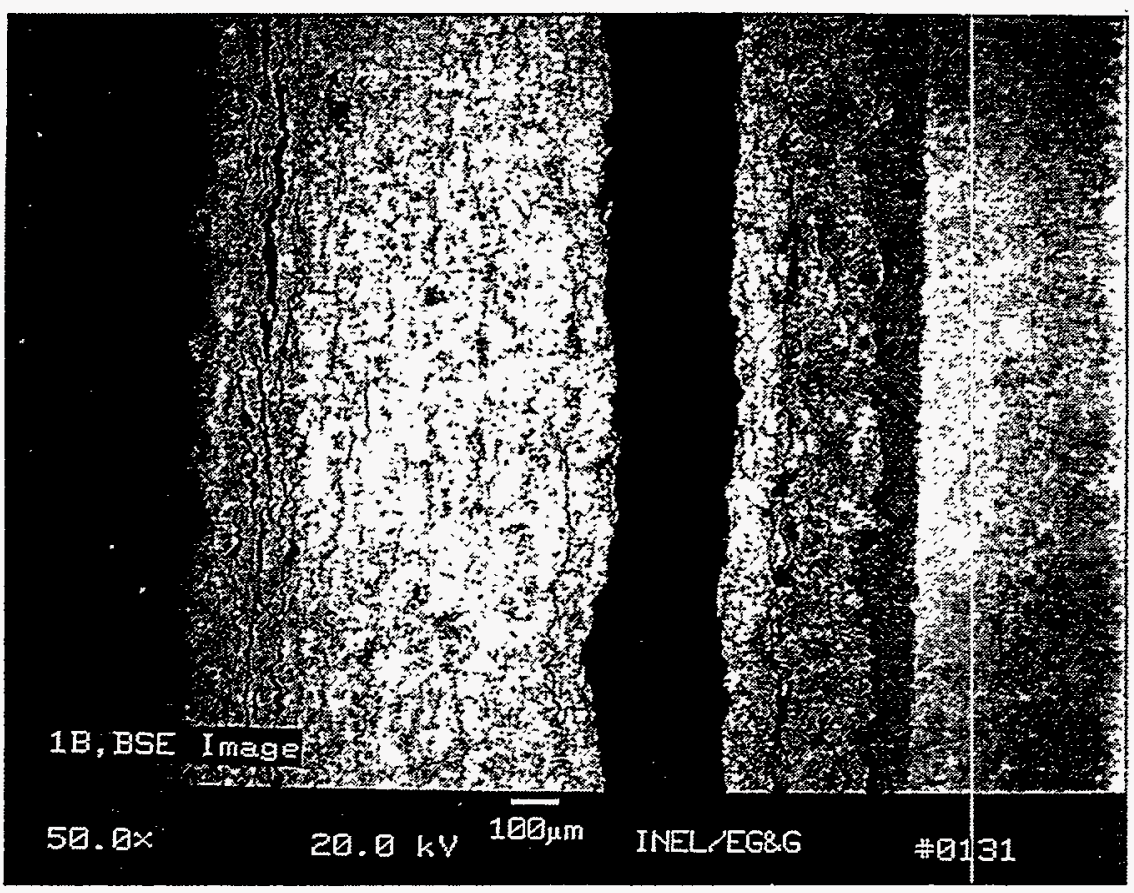

Figure 15. $50 \times$ view of 047-1. 


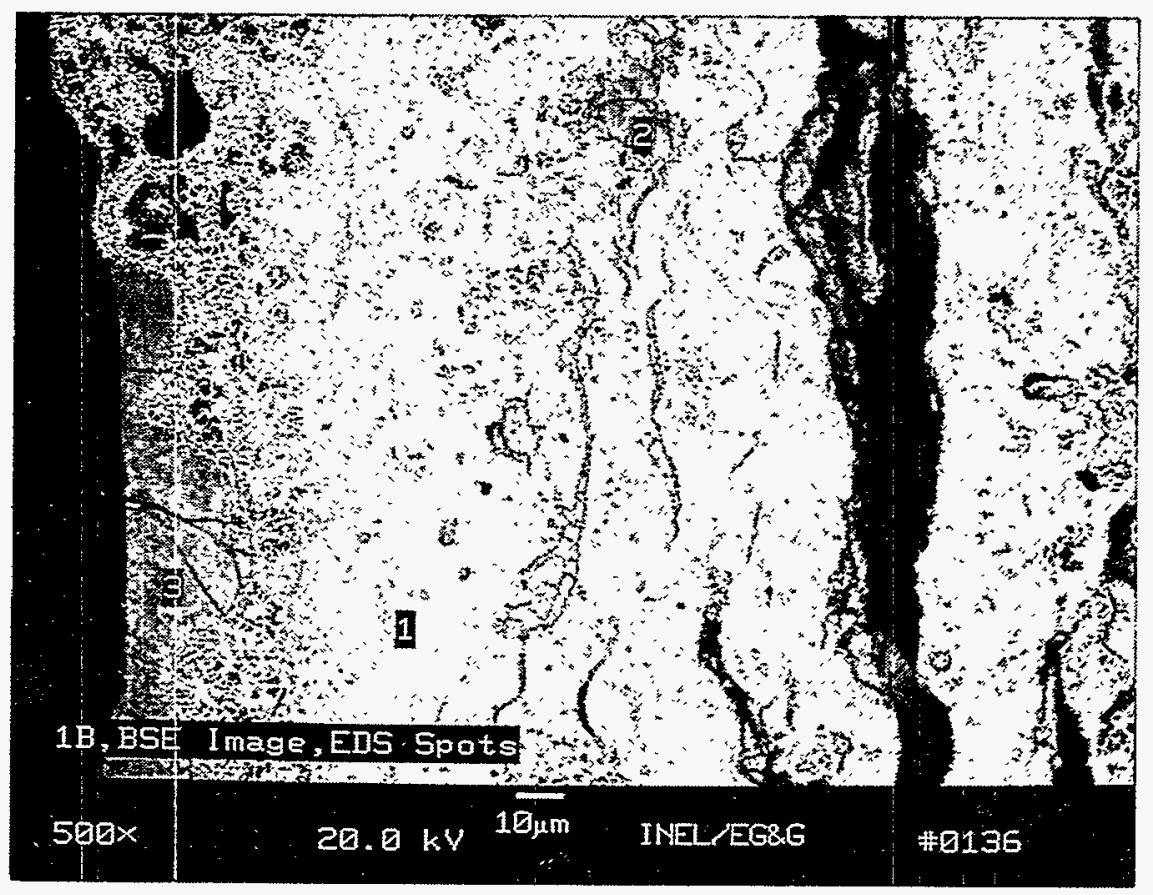

Figure 16. $500 \times$ view of 047-1.

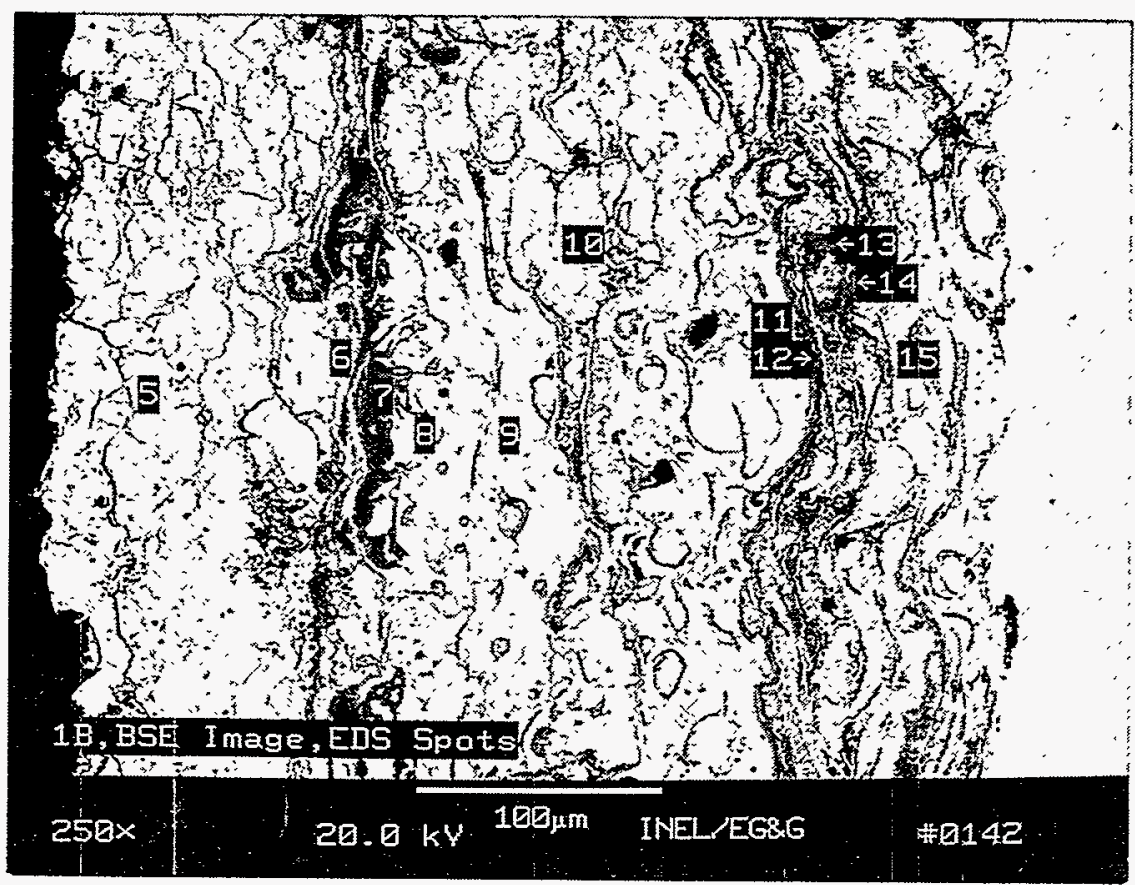

Figure 17. $250 \times$ view of 047-1. 
Table 6. Results of analysis of 047-1.

\begin{tabular}{|c|c|c|}
\hline & 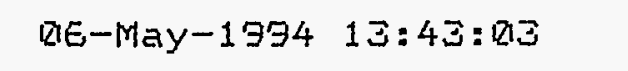 & $1 E-1$ \\
\hline Acce 1 & Lerating voltage & EQl. Q KeV \\
\hline Eearn & - sample inciderice argle & $\exists \bar{a} . \bar{a}$ degrees \\
\hline Xray & emergence arigle & 35.9 degrees \\
\hline Xray & - wirudaw inciderice argle & Q. Q degrees \\
\hline
\end{tabular}

\begin{tabular}{|c|c|c|}
\hline 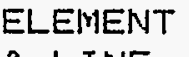 & & 5 \\
\hline LINE & F'ERCENT & F'ERCENT* \\
\hline
\end{tabular}

\begin{tabular}{|c|c|c|c|c|c|}
\hline 0 & $K A$ & 33.18 & 73.96 & 1. $\Xi 44$ & Q. .4658 \\
\hline$Y$ & $L A$. & 4. $3 \Xi$ & 1.74 & ‥ 19 & Q. Q Q \\
\hline$Z_{r}$ & LA & 61.38 & $\because 4 . Q E$ & 8.40 & ฉ. $558=$ \\
\hline $\mathrm{Hf}$ & LA & 1. $\Xi Z_{2}$ & Q1. $=4$ & ถ. $E$ & 0. 01037 \\
\hline
\end{tabular}

TOTAL $\quad 1018.801$

ITERATIONS $\quad 9$

*NOTE: ATOMIC FERCENT is rummalized ta 1 QRa

**NOTE: K-RATIO $=K$-RATIO $\times R$

where $R$ = refererice (staridard)/refererice (sample)

NORMALIZATION FACTOR: 1. QUQR 
Table 6. (continued).

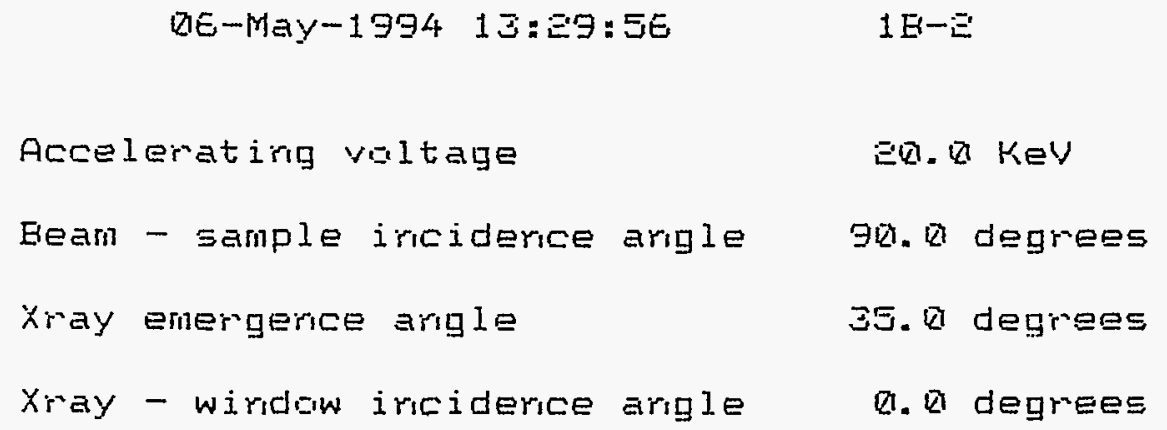

STANDARDLESS EDS ANALYSIS

(ZAF CORRECTIONS VIA MAEIC V)

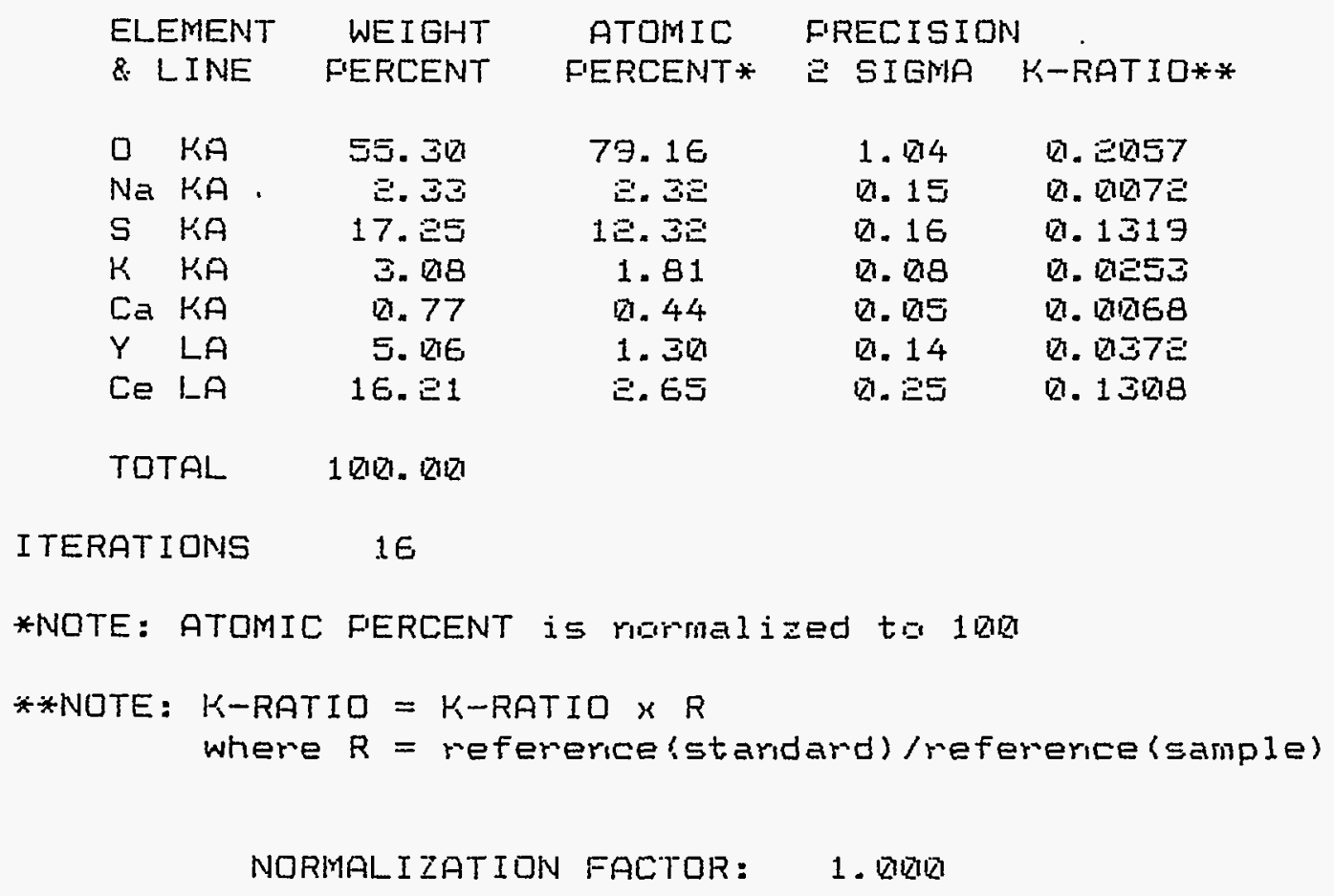


Table 6. (continued).

$\begin{array}{lc}\text { DE-May-1994 } 13: 3 E: J E & 1 \mathrm{E}-3 \\ \text { Accelerating voltage } & \Xi \text {. } 0 \text { KeV } \\ \text { Bearn - sample inciderice angle } & 90.0 \text { degrees } \\ \text { Kray emergence angle } & 35.0 \text { degrees } \\ \text { Xray - wirdaw inciderice angle } & 0.0 \text { degrees }\end{array}$

STANDARDLESS EDS ANALYSIS

(ZAF CORRECTIONS VIA MAGIC $V$ )

\begin{tabular}{|c|c|c|c|}
\hline & WE & $\pi=$ & FiR \\
\hline LINE & F'ERCENT & F'ERCENT* & E SIGMA \\
\hline
\end{tabular}

\begin{tabular}{|c|c|c|c|c|c|}
\hline 0 & $K A$ & 54.98 & $78.6 \Xi$ & 1. $.2 E$ & ㅁ․ $\Xi 175$ \\
\hline $\mathrm{Na}$ & $K A$ & $3.4 E$ & 3.44 & 0.18 & 0.0105 \\
\hline S & $K A$ & 17. . & $1 \Xi .15$ & 0.16 & ㅁ. 1315 \\
\hline K & $K A$ & E. 87 & 1. $E 8$ & Q7. 218 & ฉ. \\
\hline az & $K A$ & 10.79 & Q1. 45 & 12. 815 & Q. Q1078 \\
\hline Y & LA & $\Xi .5 E$ & D. $E \in$ & Q. 11 & Q. 0184 \\
\hline $\mathrm{Ce}$ & $L A$ & 18. コこ & E. 99 & Q. 27 & D. 1485 \\
\hline
\end{tabular}

TOTAL 10R. QRT

ITERATIONS $\quad 14$

*NOTE: ATOMIC FERCENT is mamalized ta 1 Q

**NOTE: K-RATIO $=K$-RATIO $\times R$

where $R=$ reference (staridard)/refererice (sample)

NORMALIZATION FACTOR: 1 . QUDO 
Table 6. (continued).

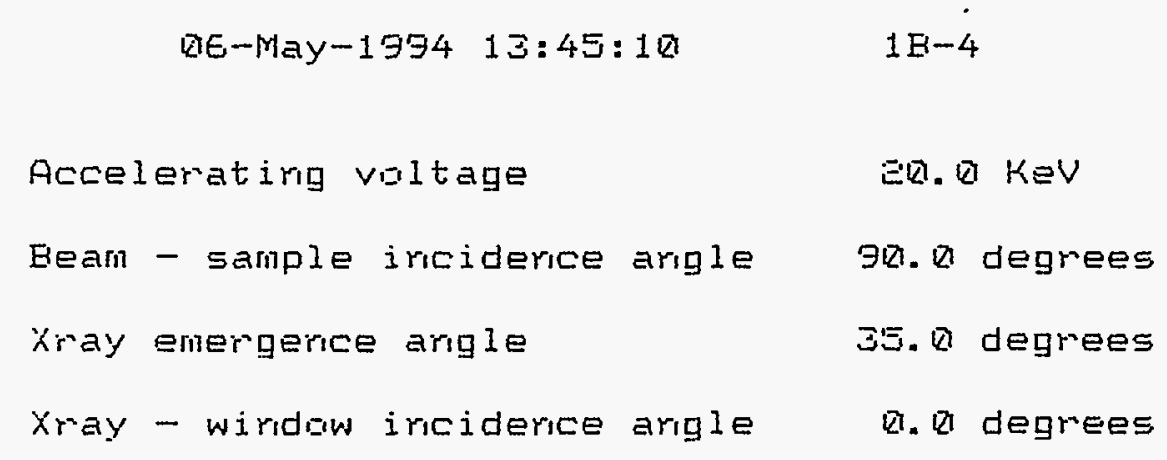

STANDARDLESS EDS AMALYSIS

(ZAF CORRECTIONS VIA MAGIC $V$ )

\begin{tabular}{|c|c|c|c|c|}
\hline \multirow{2}{*}{ ELEMENT } & \multirow{2}{*}{$\begin{array}{r}\text { WEIGHT } \\
\text { F'ERCENT }\end{array}$} & \multirow{2}{*}{$\begin{array}{c}\text { ATOMIC } \\
\text { F'ERCENT* }\end{array}$} & \multicolumn{2}{|c|}{ FRECISION } \\
\hline & & & $\Xi$ SIGMA & K-RATIC \\
\hline$K A$ & Зコ. & 73. & 1. & Q \\
\hline LA & 7.59 & 3.11 & Q17. Ë & $87 \Xi$ \\
\hline$Z_{r}{ }^{2} L A$ & 59.26 & $\Xi 3 . E 1$ & ㅁ. 39 & Q. $538=$ \\
\hline HF LA & 1. 31 & Q. 27 & ฉ1. 25 & $\square . \square \perp \square \in$ \\
\hline
\end{tabular}

TOTAL 100.800

ITERATIONS 1 II

*NOTE : ATOMIC FERCENT is rurmalized ta 1 Ga

**FIOTE: K-RATIO $=K$-RATIO $\times R$

where $R$ = reference (staridard)/reference (sample)

NORMALIZATION FACTOR: 1. QRZIO 
Table 6. (continued).

\begin{tabular}{|c|c|c|}
\hline & DE-May-1934 13:40: DEZ & $1 E-5$ \\
\hline Acce & Ierating valtage & $\Xi 0.0 \mathrm{KeV}$ \\
\hline Eearn & - sample iriciderice angle & 90.0 degrees \\
\hline Xray & emergence angle & 35.8 degrees \\
\hline Xray & - windaw incidence angle & Q1. Q degrees \\
\hline
\end{tabular}
(ZAF CORRECTIONS VIA MAGIC $V$ )

\begin{tabular}{|c|c|c|}
\hline IT & WE & AT \\
\hline
\end{tabular}

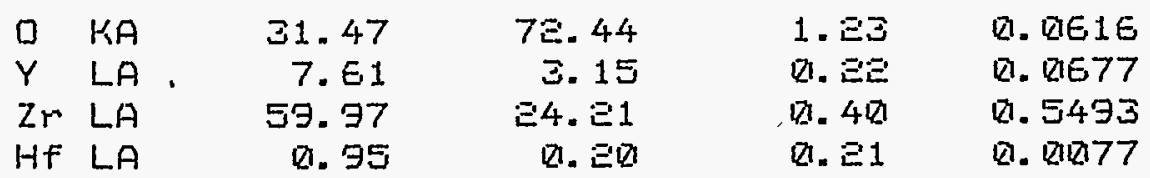

TOTAL $\quad 1818$. DIR

ITERATIONS 1 TI

*NOTE: ATOMIC FERCENT is rurmalized to 1 RR

**NOTE: K-RATIO = K-RATIO $\times R$

where $R=$ refererice (staridard)/reference (sample)

NORMALIZATION FACTOR: 1 . RQQZI 
Table 6. (continued).

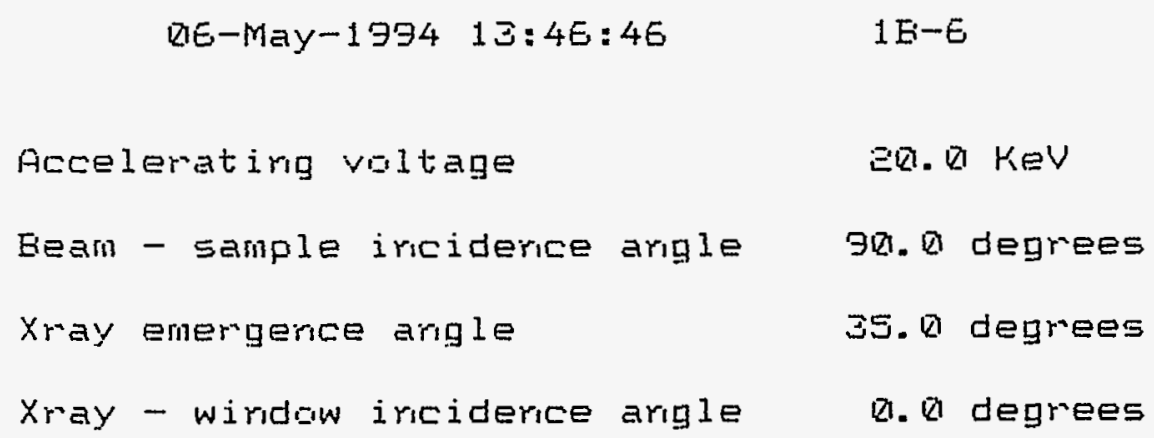

STANDARDLESS EDS ANALYSIS
(ZAF CORRECTIONS VIA MAGIC V)

\begin{tabular}{|c|c|c|c|c|}
\hline ELEMENT & WEIGHT & ATOMIC & FRECISION & \\
\hline \& LINE & FERCENT & FERCENT* & $\Xi$ SIGMA & $K-R A T I D *$ \\
\hline$K A$ & 39. & $54 . \Xi 1$ & Q. 30 & 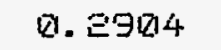 \\
\hline$\because K A$ & Q7. & D. 48 & a. .218 & 0.02054 \\
\hline i $K A$ & $6 Q .13$ & $45.3 Q$ & Q. $6 \square$ & Q.57 57 \\
\hline
\end{tabular}

TOTAL 1DRQR. RIBZ

ITERATIONS 9

*NOTE: ATOMIC FERCENT is rumalized to 1 RI

* *NOTE: K-RATIO $=K-$ RATIO $* R$

where $R=$ refererice (staridard)/refererice (sample)

NORMALIZATION FACTOR: $1 . \square Q \square \square$ 
Table 6. (continued).

$$
\text { QE-May-1994 } 13: 50: \Xi 7 \quad 1 E-7
$$

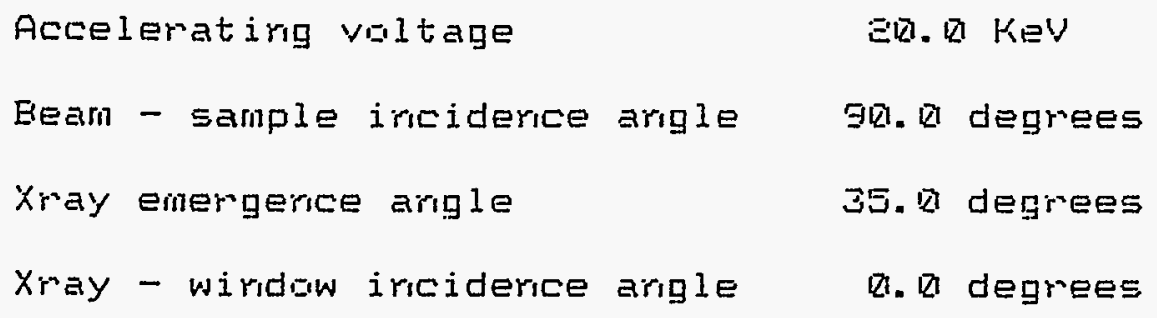

STANDARDLESS EDS ANALYSIS

(ZAF CORRECTIONS VIA MAGIC $V$ )

\begin{tabular}{|c|c|c|c|c|}
\hline ELEMENT & WEIGHT & ATAMIC & \multicolumn{2}{|c|}{ FRECISION } \\
\hline \& LINE & F'ERCENT & F'ERCENT* & $=$ SIGMA & $K-$ RATID*** \\
\hline$K A$ & उЗ. EE & EE்.37 & 1.64 & Q. 1764 \\
\hline$A I K A$ & Е.73 & こ. 99 & D. 14 & ฉ. $\square 116$ \\
\hline Si KA & 1.79 & 1.89 & Q1. 10 & घ. \\
\hline$S K A$ & 0.75 & Q. $E 9$ & 12. 197 & จ. 01254 \\
\hline Cl $\mathrm{KA}$ & 1.77 & 1.48 & Q. $\square 9$ & 0. 1135 \\
\hline $\mathrm{Cr} \cdot \mathrm{K}, \mathrm{A}$ & ЕЭ.EE & 16.71 & Q. $3: 3$ & 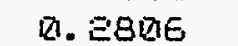 \\
\hline FE $K A$ & $8 . \in \square$ & Q1. $3 \Xi$ & 81.89 & ด. ด1855 \\
\hline$N i \quad K A$ & 13.18 & $E . E 5$ & Q. .39 & ㅁ. $1=47$ \\
\hline$Z n K A$ & 1モ.モ゙4 & 5.55 & 0.37 & Q. 1076 \\
\hline$Y \quad L A$ & 3.121 & 1. $\square \square \square$ & Q. 1.15 & Q. 8193 \\
\hline Ce LA & $R, E \Xi$ & Q. 13 & 0.12 & Q. 21055 \\
\hline
\end{tabular}

TDTAL $\quad 108.81$

ITERATIONS $\quad 9$

*NOTE: ATOMIC FERCENT is rigmalized ta 1QR

**NOTE: $K$-RATIO $=K$-RATIO $\times R$

where $R=$ reference (staridard)/refererice (sample)

NORMALIZATION FACTOR: 1. QRQR 
Table 6. (continued).

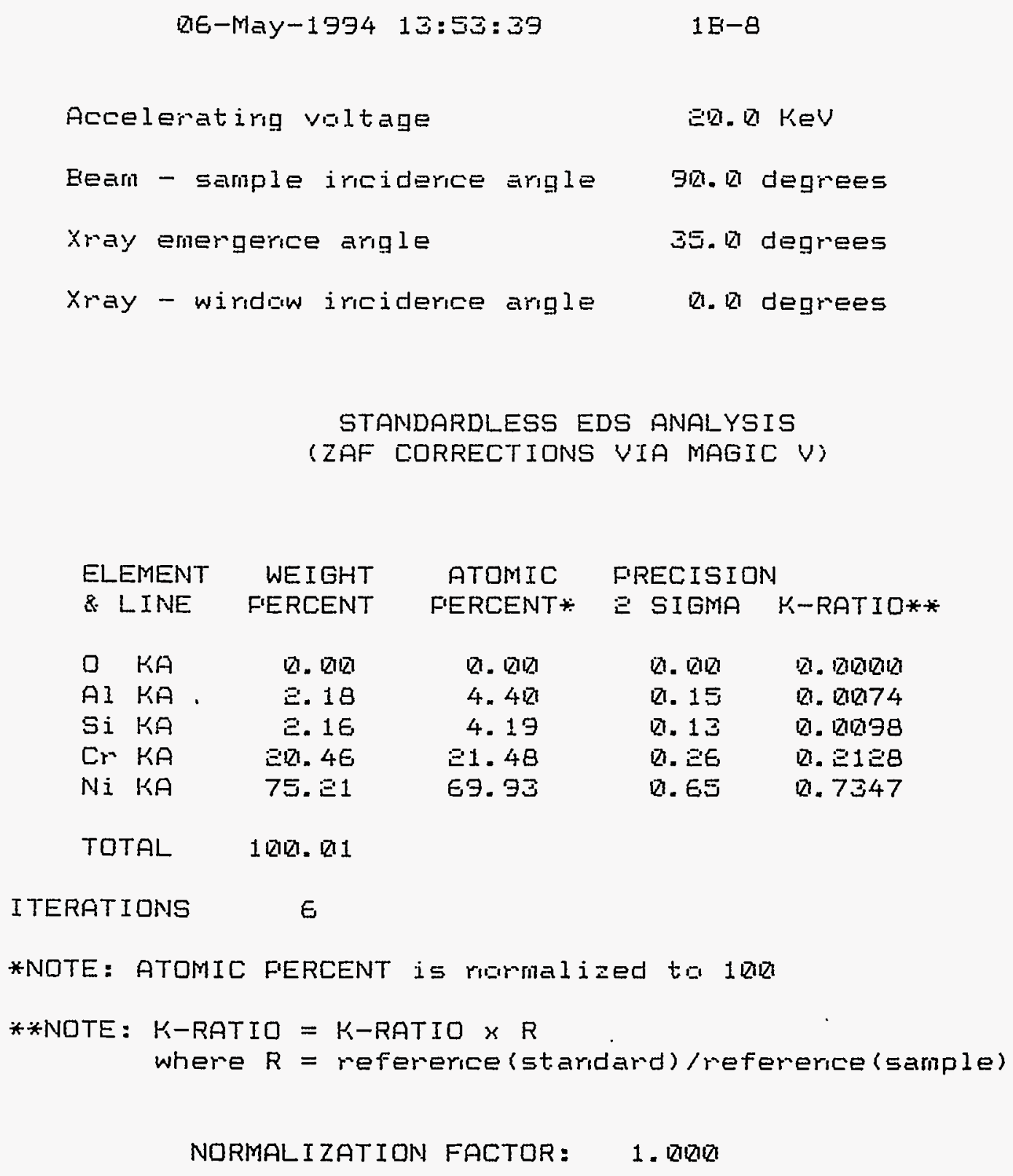


Table 6. (continued).

\begin{tabular}{|c|c|}
\hline DE-May-1994 1Ј: $5 E:$ Q & $1 \mathrm{~B}-9$ \\
\hline Accelerating valtage & EQ.Q KeV \\
\hline Eeam - sample iriciderice arigle & $9 \square . \square$ degrees \\
\hline Kray emergence arigle & 35.8 degrees \\
\hline Xray - wiridow iriciderice arigle & Q $Q$. degrees \\
\hline
\end{tabular}

STANDARDLESS EDS ANALYSIS
(ZAF CORRECTIONS VIA MAGIC $V$ )

\begin{tabular}{|c|c|c|c|c|}
\hline ELEMENT & WEIGHT & ATOMIC & \multicolumn{2}{|c|}{ F'RECISIQN } \\
\hline \& INE & FERCENT & FIERCENT* & $\Xi$ SIGMA & K-RATI $\square * * *$ \\
\hline $\mathrm{KA}$ & $3 n . \nabla \theta$ & 71.13 & 1.19 & 2. $858=$ \\
\hline LA & 8. 38 & 3.57 & ㅁ. $\Xi 3$ & Q. 0748 \\
\hline$Z r \quad L A$ & $E Q 1.47$ & 25.07 & 0.40 & 8. 5558 \\
\hline HF LA & 1.87 & Q. $\Xi 3$ & Q. E. E & ㄱ. МपूВ7 \\
\hline TOTAL & 100.00 & & & \\
\hline
\end{tabular}

ITERATIONS IR

*NOTE: ATOMIC FERCENT is ricmalized to 1 QR

**NOTE: K-RATIO $=$ K-RATIO $\times R$

where $R=$ refererice (staridard)/refererice (sample)

NORMALIZATION FACTOR: 1. QIZIR 
Table 6. (continued).

$\begin{array}{ll}\text { QE-May-1934 13:57:45 } & 1 E-1 Q \\ \text { Accelerating voltage } & \text { EQ. Q KeV } \\ \text { Eeam - sample iriciderice argle } & 9 Q . \text { degrees } \\ \text { Xray emergerice arigle } & 35 . Q \text { degrees } \\ \text { Xray - windaw inciderice argle } & \square .0 \text { degrees }\end{array}$

STANDARDLESS EDS ANALYSIS

(ZAF CORRECTIONS VIA MAGIE $V$ )

\begin{tabular}{|c|c|c|c|c|}
\hline \multirow{2}{*}{$\begin{array}{l}\text { ELEMENT } \\
\& \text { LINE }\end{array}$} & WEIGHT & ATOMIC & \multicolumn{2}{|c|}{ FRECISION } \\
\hline & FERCENT & F'ERCENT* & $\Xi$ SIEMA & K-RATIO** \\
\hline$K A$ & 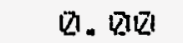 & $\square 1.82$ & Q. 80 & Q1. $\nabla|Q| Q|B| Z \mid$ \\
\hline Al KA & 1.81 & $\Xi . \not 29$ & 0.13 & Q. 210334 \\
\hline$S i K A$ & $1.7 \mathrm{~B}$ & 3. 36 & 2. 12 & 0.8977 \\
\hline $\mathrm{Cr}^{-} \mathrm{KA}$ & $19.4 E$ & EZا1. 8E & ฉ. $\Xi 6$ & Q1. 2034 \\
\hline FE KA & Q. $4=$ & 18. 40 & Q. 2.8 & 0.8047 \\
\hline $\mathrm{Ni} K A$ & 77.40 & 73.31 & Q. 68 & 0.7576 \\
\hline OTAL & 99 & & & \\
\hline
\end{tabular}

ITERATIONS

$\varepsilon$

*NOTE: ATOMIC FERCENT is rommalized to 1 ba

**NOTE: K-RATIO = K-RATIO $\times R$

where $R=$ refererice (stardard)/reference (sample)

NORMALIZATION FACTOR: 1. DRG 
Table 6. (continued).

\begin{tabular}{|c|c|}
\hline घ1E-May-1994 13:59:59 & $1 E-11$ \\
\hline Accelerating valtage & EQ. Q KeV \\
\hline Eeari - sample inciderice angle & $9 \square . \overline{\text { degrees }}$ \\
\hline Xray emergence angle & 35.8 degrees \\
\hline Xray - wirudaw iriciderice argle & Q0. 0 degrees \\
\hline
\end{tabular}

STANDARDLESS EDS ANALYSIS
(ZAF CORRECTIONS VIA MAGIC V)

$\begin{array}{lccl}\text { ELEMENT } & \text { WEIGHT } & \text { ATOMIC } & \text { FRECISION } \\ \text { \& LINE } & \text { FERCENT FERCENT* E SIGMA K-RATIO** }\end{array}$

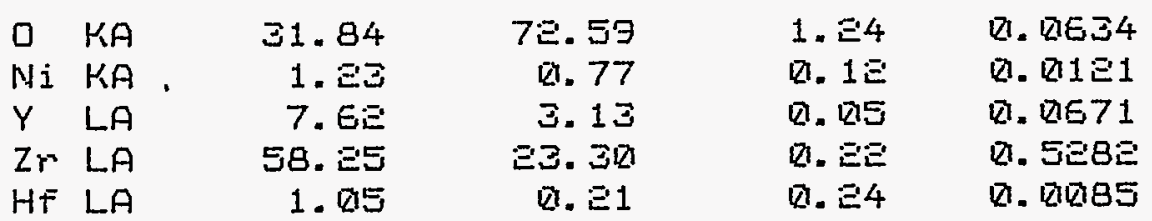

TOTAL 99.99

ITERATIONS 18

*NOTE: ATOMIC FERCENT is romalized ta 1 bra

* *NOTE: K-RATIO $=K$ K-RATIO $* R$

where $R=$ reference (staridard)/refererice (sample)

NORMALIZATION FACTOR: 1. QRQR 
Table 6. (continued).

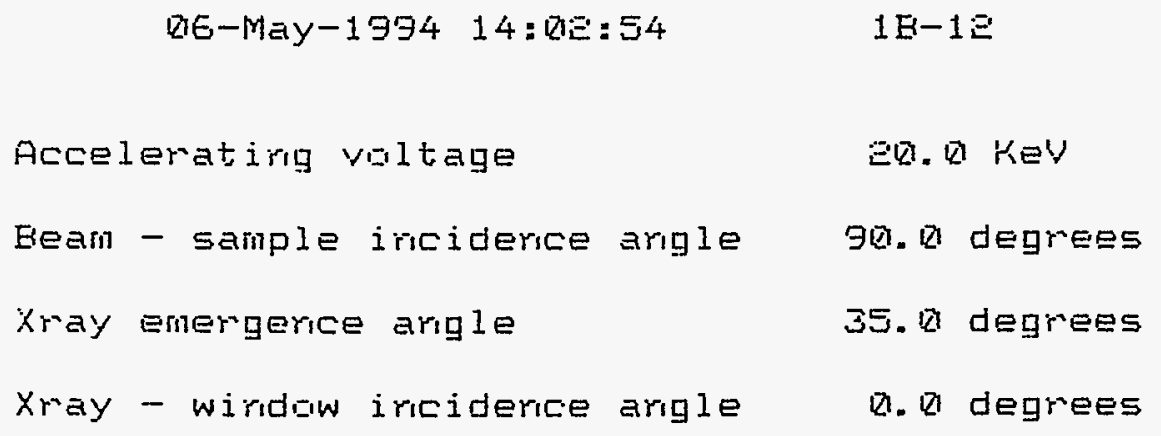

STANDARDLESS EDS ANALYSIS

(ZAF CORRECTIUNS VIA MAGIC $V$ )

\begin{tabular}{|c|c|c|}
\hline$L$ & WEIGHT & ATOMIC \\
\hline LINE & FERCENT & FERCENT* \\
\hline
\end{tabular}

\begin{tabular}{|c|c|c|c|c|c|}
\hline 0 & KA & 34.84 & 58.49 & 1. 36 & ๑. $19 \Xi 1$ \\
\hline Al & $K A$ & 7.19 & 7.58 & ฉ. 19 & Q. $831 \Xi$ \\
\hline Si & KA & 1.97 & 1.99 & 0.18 & 0.0104 \\
\hline 5 & $K A$ & 1.Eシ & 1.88 & Q1. 877 & 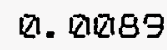 \\
\hline $\mathrm{Cl}$ & $\mathrm{KA}$ & 0.76 & Q. $E 1$ & 0.077 & 8. Q 8058 \\
\hline $\mathrm{Cr}$ & KA & Е7. 34 & 14.95 & Q1. 30 & 凸. $\Xi E \Omega=$ \\
\hline $\mathrm{Ni}$ & KA & $=7.48$ & 13.30 & 0.48 & ฉ. $: 5: \Xi \square$ \\
\hline
\end{tabular}

TOTAL 1QMZI. QRQ

ITERATIONS $\quad \exists$

*NDTE: ATOMIC FERCENT is marmalized ta 1 DQ

**NOTE: K-RATIO $=K-$ RATIO $\times R$

where $R=$ refererice (stardand)/refererice (sample)

NORMALIZATION FACTOR: 1. QQQQ 
Table 6. (continued).

\begin{tabular}{|c|c|c|}
\hline & $\nabla \in-M a y-1994 \quad 14: 017: 14$ & $1 B-1 \Xi$ \\
\hline Accel 1 & Eratirug voltage & EQR. Q KEV \\
\hline Eean & - sample iriciderice argle & 90.0 degrees \\
\hline Xray & emergence angle & 35.0 degrees \\
\hline Xray & - wiridaw iriciderice angle & Q. 0 degrees \\
\hline
\end{tabular}

$\begin{array}{lccl}\text { ELEMENT } & \text { WEIGHT } & \text { ATOMIC } & \text { FRECISION } \\ \& \text { LINE } & \text { FERCENT FERCENT* E SIGMA K-RATIQ** }\end{array}$

\begin{tabular}{|c|c|c|c|c|c|}
\hline 0 & $K A$ & ت4. こ4 & 48.30 & 7.19 & ๑. 1こ日E \\
\hline Al & $K A$ & 1Q7. $\nabla \in$ & 11.89 & Q.Eシ & 0.81430 \\
\hline $\mathrm{Si}$ & $K A$ & シ. 5る & Е. 88 & Q & $0.012=$ \\
\hline $\mathrm{s}$ & $K A$ & घ. 69 & $Q .69$ & D. 1817 & (2). \\
\hline CI & $K A$ & Q. .54 & ㅁ. 49 & Q. $\Delta E$ & 0.80141 \\
\hline $\mathrm{Ca}$ & $K A$ & Q1. $\Xi 4$ & 미. 19 & Q. 1215 & В1. QRRËこ \\
\hline $\mathrm{Cr}$ & $K A$ & 29.63 & 18.17 & 0.32 & 0.2850 \\
\hline $\mathrm{Ni}$ & $K A$ & उE. DIE & 17.41 & Q1. 45 & ๑. ᄅЭEB \\
\hline
\end{tabular}

TOTAL $\quad 99.99$

ITERATIONS $\quad 8$

*NOTE: ATOMIC FERCENT is rumalized to 1 RU

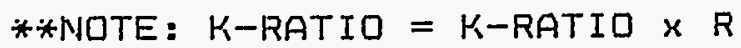

where $R=$ refererice (staridard)/refererice (sample)

NORMALIZATION FACTOR: $1 . Q Q \square$ 
Table 6. (continued).

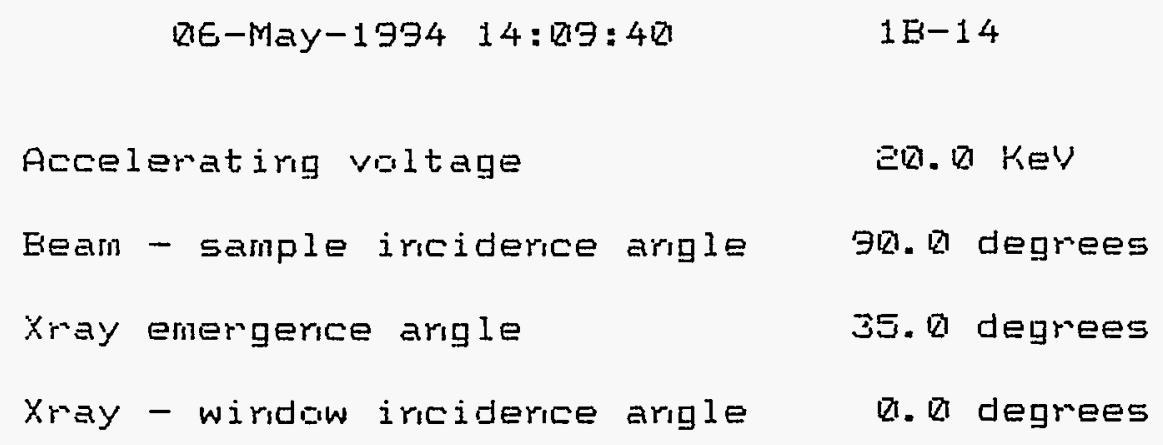

STANDARDLESS EDS ANALYSIS

( $Z A F$ CORRECTIONS VIA MAGIE $V$ )

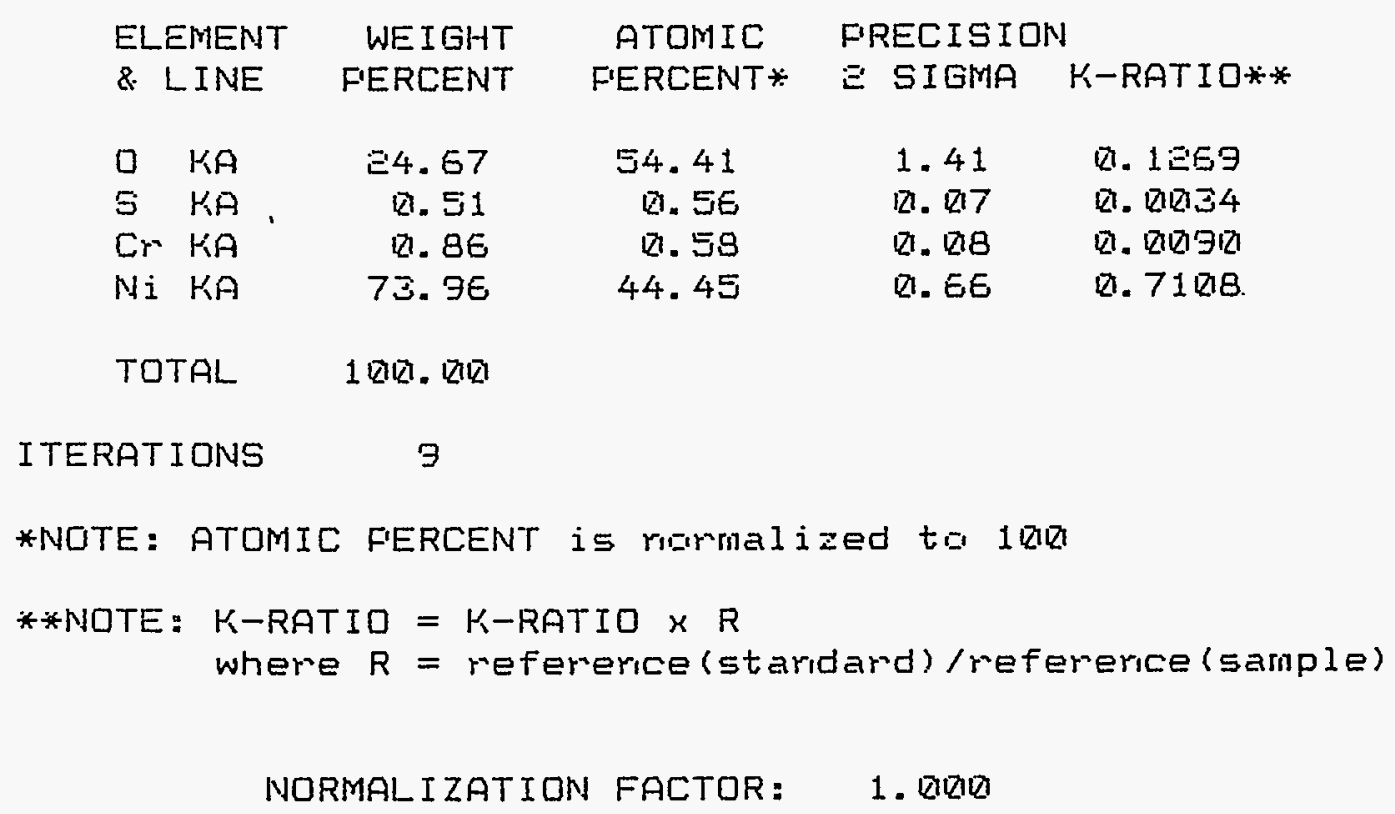


Table 6. (continued).

$$
\nabla G-M a y-1994 \quad 14: 11: 49 \quad 1 \mathrm{~B}-15
$$

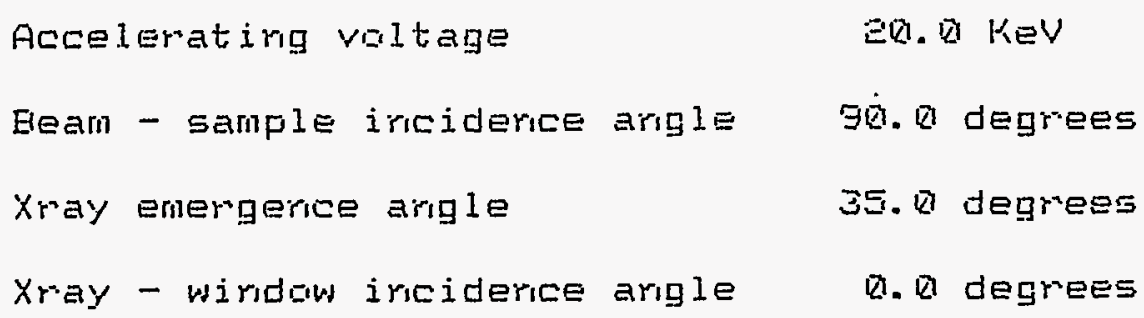

STANDARDLESS EDS ANALYSIS

(ZAF CORRECTIONS VIA MAGIC $v$ )

\begin{tabular}{|c|c|c|c|c|}
\hline ELEMENT & WEIGHT & ATOMIC & \multicolumn{2}{|c|}{ FRECISION } \\
\hline \& LINE & FERCENT & FERCENT* & $\Xi$ SIGMA & $K-R A T I D *$ \\
\hline$A 1 K A$ & 10.40 & 19.65 & ㅁ.. \pm 6 & Q. 0367 \\
\hline$S i K A$ & 1. 62 & シ. ヨシ & 0. $1 E$ & ㅁ. $\operatorname{\square \square } 71$ \\
\hline Cr KA & 13.16 & $1 \pm .83$ & Q. 20 & Q. $13 E_{4}$ \\
\hline$F E M A$ & 0.30 & B. $\Xi 8$ & Q1. 817 & 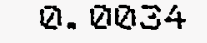 \\
\hline $\mathrm{Ni} K A$ & $74.4 E$ & $E 4.3 \Xi$ & V1. 65 & 0.7275 \\
\hline
\end{tabular}

TOTAL 1Q0. Q18

ITERATIONS $\quad \epsilon$

*NOTE: ATOMIC FERCENT is Mamalized ta 1 QR

* NDTE: K-RATID $=K-$ RATIO $\times R$

where $R=$ refererice (staindard)/reference (sample)

NORMALIZATION FACTOR: 1. DRQR 


\subsubsection{Coating 048-10}

An overall view of a failed coating (048-10) is shown in Figure 5. A cross-section of the failed coating shown in Figure 18 shows that there are numerous areas of coating delamination. It appears that the cracking affected all the interfaces between the layers. Figure 19 is a higher magnification view of the failed coating where there is only one crack present between the intermediate blended layer and the bond layer. There is a mixed layer of mixed deposits on the surface which was analyzed and the results tabulated in Table 7. A description follows (see Figures 19-21):

Areas 1-6 These areas are shown in Figure 19 with the EDS analysis given in Table 7. The crystalline deposits have varying compositions that include corrosion products from the nickel-based alloys, the added surrogate materials, and the decomposition products from the destruction of the Trimsol.

Areas 7-8 These areas are the ceramic top coat of yttria-stabilized zirconia.

Area 9 This area is the alumina intermediate ceramic top coat.

Area 10 This area is the alumina intermediate ceramic top coat with a small amount of waste elements.

Area 11 This area is yttria-stabilized zirconia with a small amount of NiCrAl.

Area 12 This area is the NiCrAl bond coat with a large amount of elements from the simulated waste stream $(\mathrm{S}, \mathrm{Cl})$ present. Silica is an impurity present in the spray powder and could be an artifact from the preparation prespray surface that uses grinding papers.

Area 13 This area shows the bond layer chemistry ( $\mathrm{NiCrAl}$ ) with spray powder impurities (Fe, Si).

Area 15 This is a mixed oxide particle where the constituent elements were oxidized during the spray process.

Area 14, 16 These areas are the $\mathrm{NiCrAl}$ bond coat with the iron and silica being impurities in the plasma spray powder. (The nominal chemistry of the prealloyed powder is Ni-balance, C-19\%, Al-6\%.)

Observations: The multiple top coatings did not inhibit coating failure. 


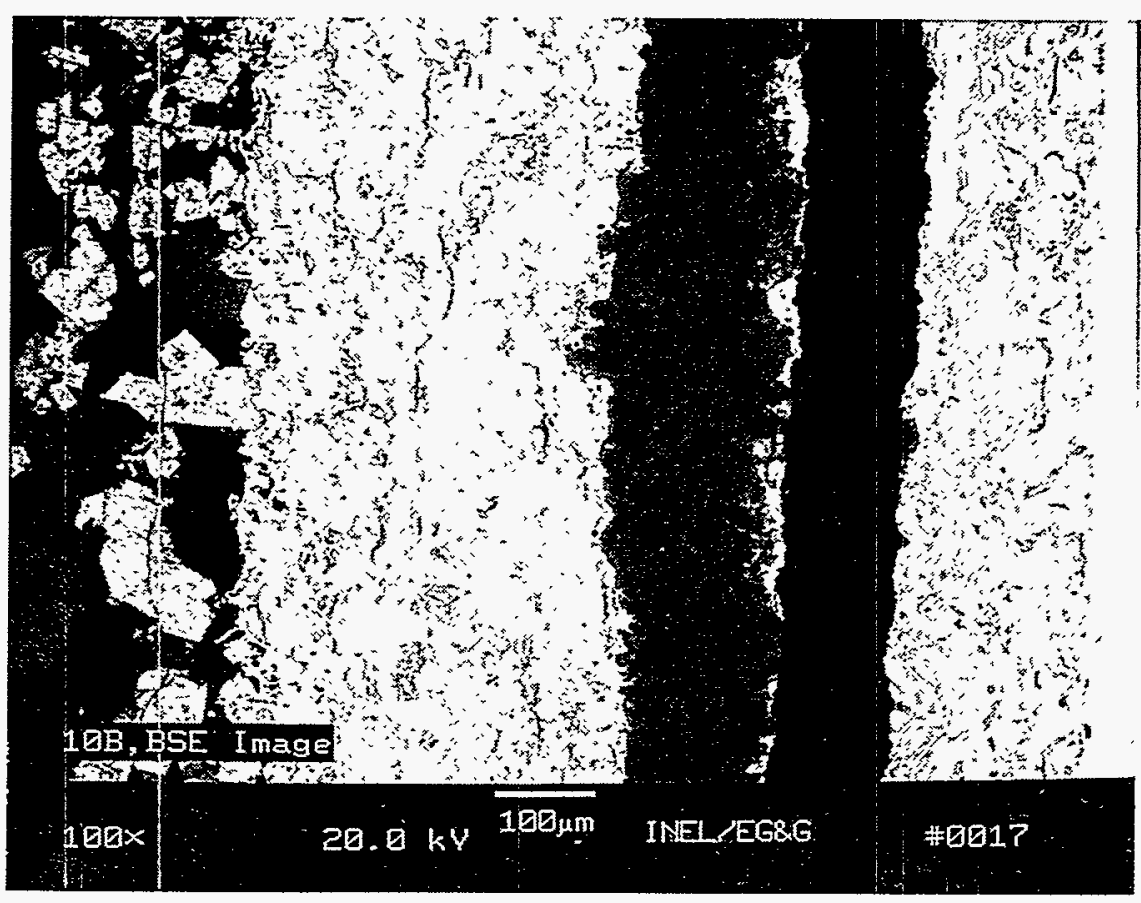

Figure 18. $100 \times$ view of 048-10.

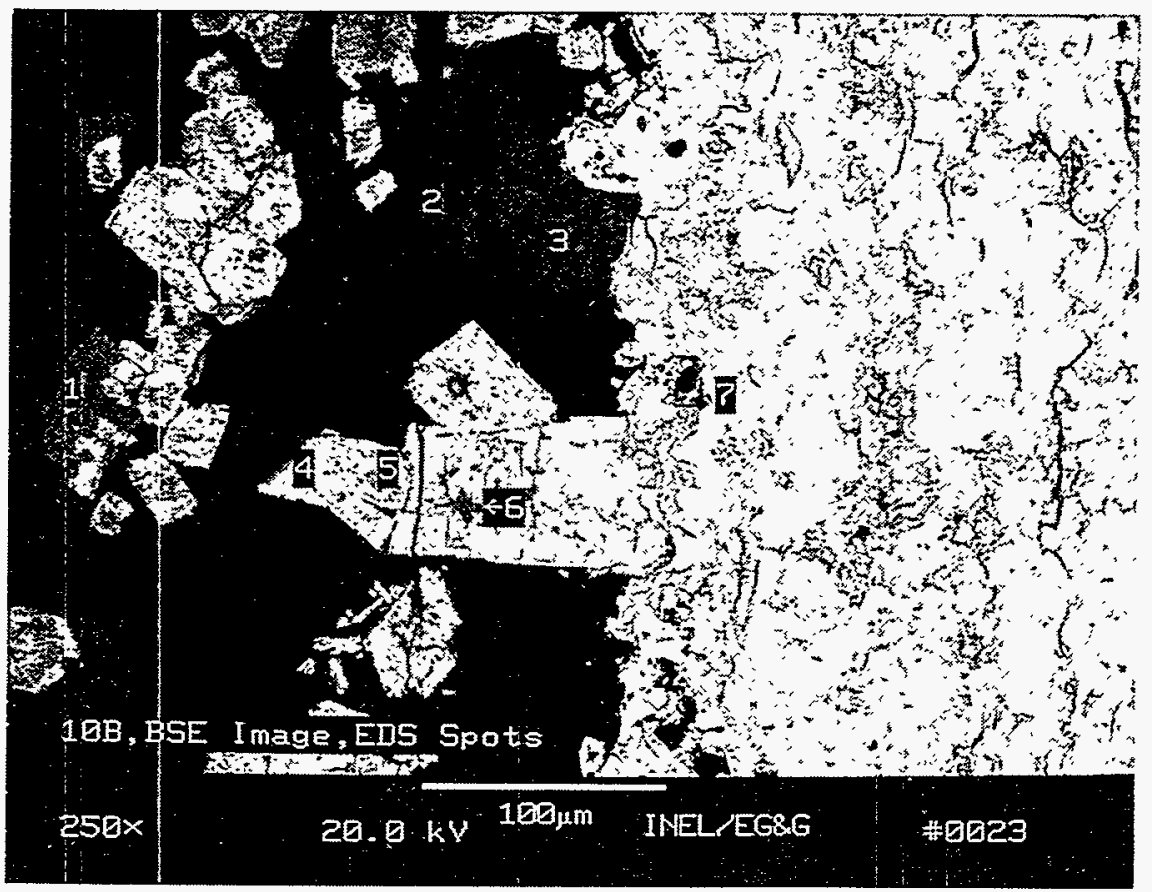

Figure 19. $250 \times$ view of 048-10. 


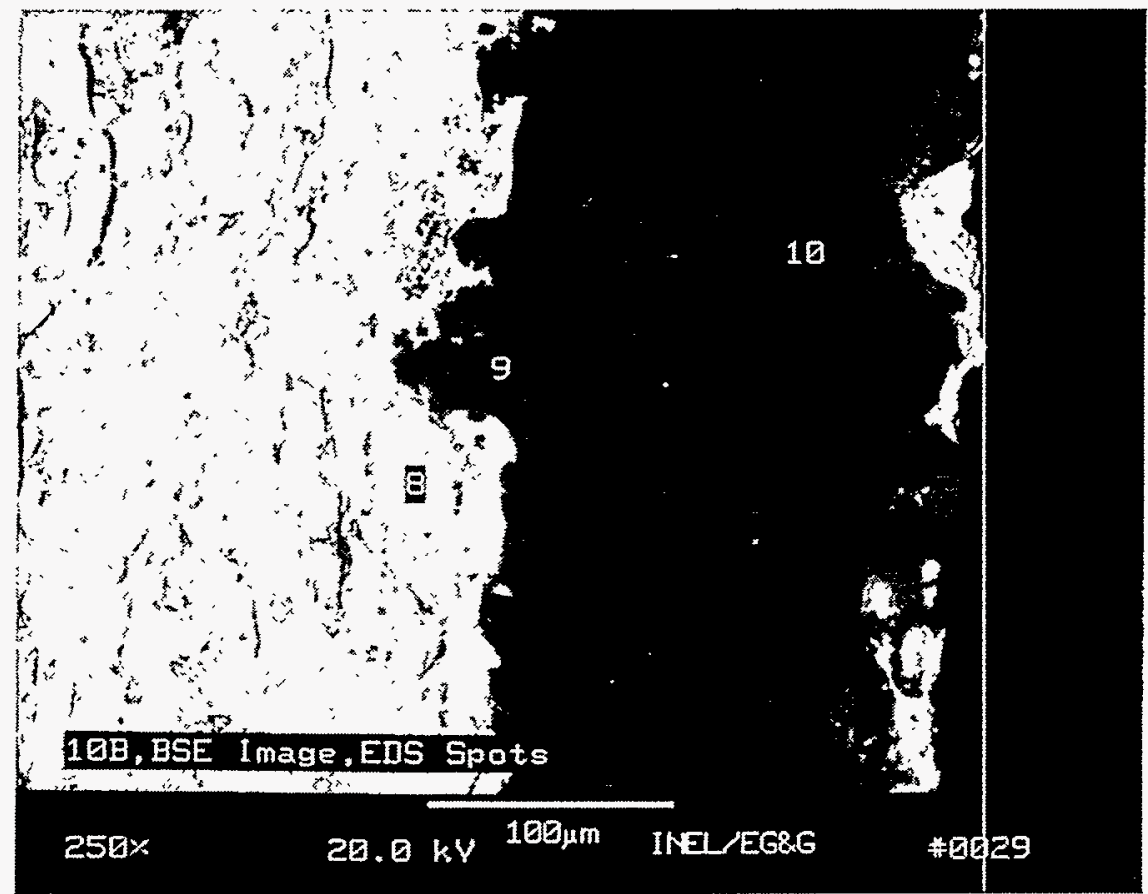

Figure 20. $250 \times$ view of 048-10.

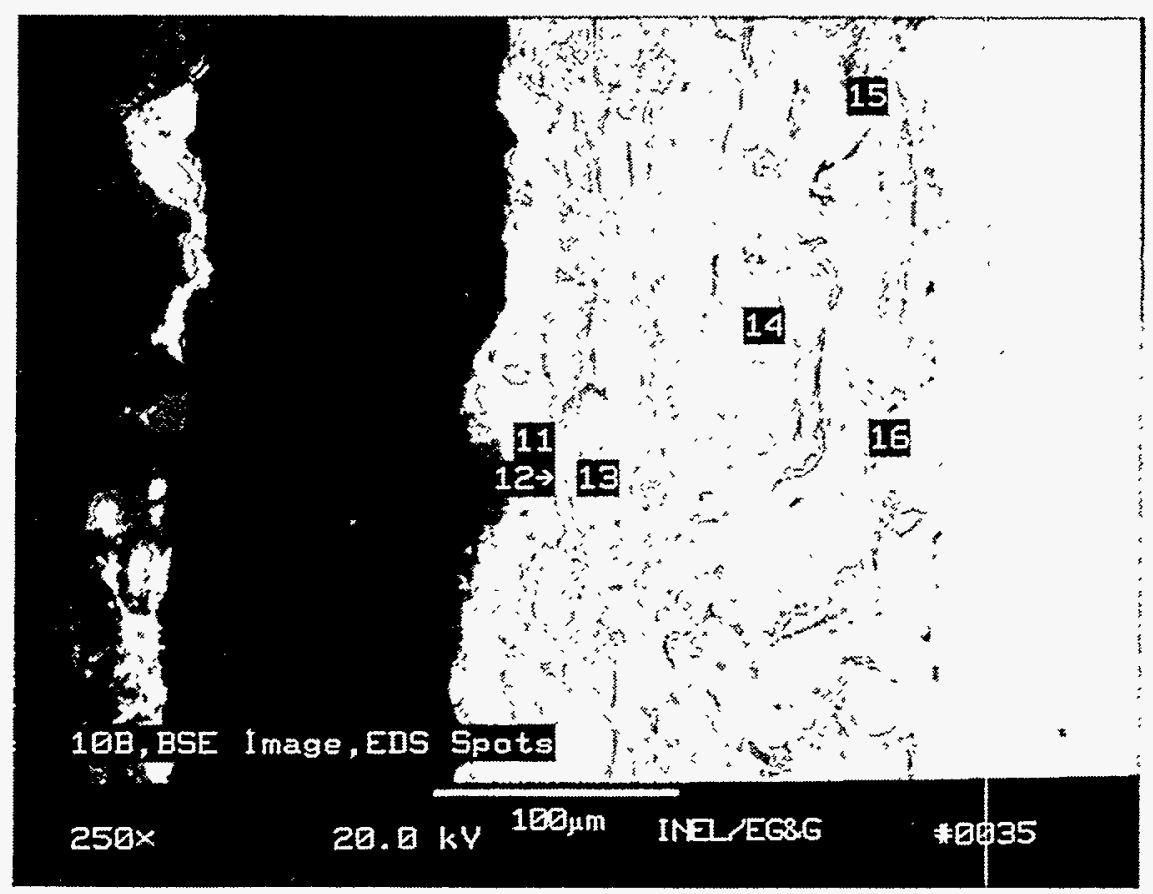

Figure 21. $250 \times$ view of 048-10. 
Table 7. Results of analysis of 048-10.

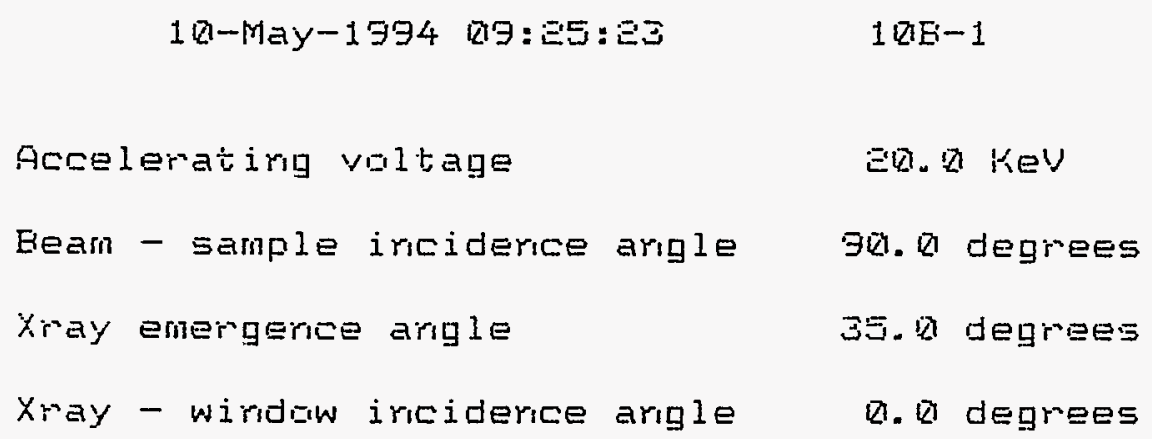

STANDARDLESS EDS ANALYSIS

(ZAF COFRECTIONS VIA MAGIC $V$ )

$\begin{array}{lccl}\text { ELEMENT } & \text { WEIGHT } & \text { ATOMIC } & \text { FRECISION } \\ \text { \&. LINE } & \text { FERCENT FERCENT* } & \text { E SIGMA K-RATIQ** }\end{array}$

\begin{tabular}{|c|c|c|c|c|c|}
\hline 0 & $K A$ & らこ.こす & $74.9 \Xi$ & 1.74 & ฤ. อ1こロ \\
\hline 5 & $K A$ & $E 0.15$ & 14.41 & 0. 17 & Q. 2.1575 \\
\hline $\mathrm{Cr}^{2}$ & KA & Q. 27 & Q1. 13 & 0.015 & Q. Q Q1Q1E=5 \\
\hline $\mathrm{Ni}$ & $K A$ & ジ5. 98 & $1 \square .14$ & Q1. $30^{\circ}$ & ฤ. Еこヒこ \\
\hline$Z n_{1}$ & $K A$ & 1. 873 & 0.36 & 0.12 & प. पूQ日e \\
\hline $\mathrm{Ce}$ & LA & Q. $\Xi \mathrm{B}$ & ㅁ. 425 & Q2. 278 & 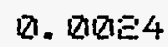 \\
\hline
\end{tabular}

TOTAL $\quad 1 Q R . Q R$

ITERATIONS $\quad 13$

*NOTE: ATOMIC FERCENT is rummalized ta 1EIb

**NOTE: KI-RATIO $=K$-RATIO $\times$ R

where $R$ = reference (staridard)/reference (sample)

NORMALIZATION FACTOR: 1 . QRQO 
Table 7. (continued).

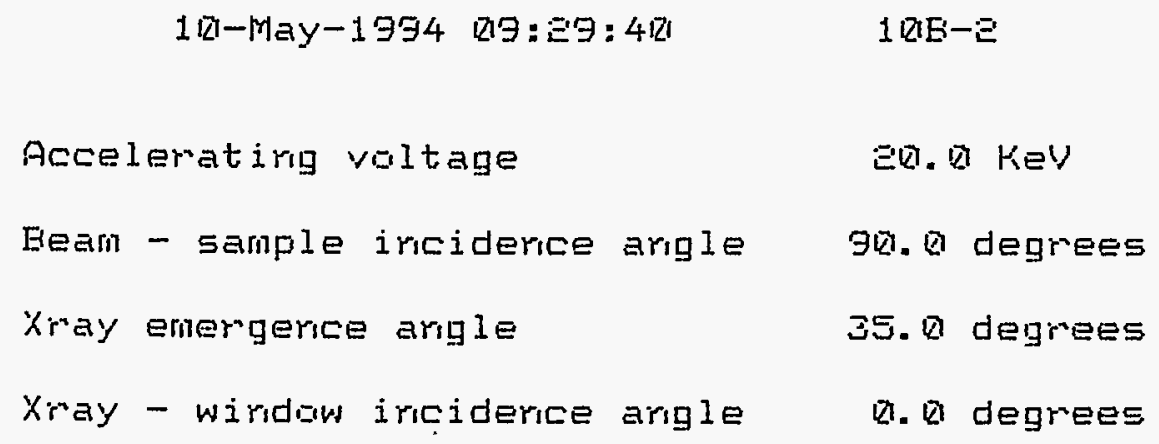

STANDARDLESS EDS ANALYSIS

(ZAF CORRECTIONS VIA MAGIC $V$ )

\begin{tabular}{|c|c|c|c|c|c|}
\hline \multicolumn{2}{|c|}{ ELEMENT } & WEIGHT & ATOMIC & \multicolumn{2}{|c|}{ FRECISION } \\
\hline$\&$ & INE & F'ERCENT & F'ERCENT* & E SIGMA & $K-R A T I \square * * *$ \\
\hline 0 & $K A$ & $E Q . \square 3$ & 73.84 & Q7. 91 & ㅁ. $\Xi 240$ \\
\hline Na & $K A$ & E. 13 & $1.8 \square$ & Q. 11 & 21. 212778 \\
\hline A. & $K A$ & $=1.18$ & 15. ジ8 & Q. 18 & ‥ 1318 \\
\hline 5 & $K A$ & $14.4 E$ & 8.78 & प1. 1E & Q. 1103 \\
\hline$K$ & $K A$ & E. 19 & 1.09 & 0.916 & Q. 0179 \\
\hline
\end{tabular}

TOTAL $\quad 99.99$

ITERATIONS 18

*NOTE: ATOMIC FERCENT is rigmalized to 100

**NOTE: K-RATIO $=$ K-RATIO $* R$

where $R=r^{*}$ efererice (staridard)/reference (sample)

NORMALIZATION FACTOR: 1. QUQ 
Table 7. (continued).

\begin{tabular}{|c|c|}
\hline $181-M a y-1994 \quad 819: 3 \Xi: 37$ & $1 \nabla \mathrm{B}-3$ \\
\hline Acceleratirg valtage & $E \nabla . Q$ KeV \\
\hline Eeam - sample imciderice argle & $\exists \not 1$. degrees \\
\hline xray energence argle & 35.8 degrees \\
\hline derice argle & D. $\nabla$ deg \\
\hline
\end{tabular}

\footnotetext{
STANDARDLESS EDS ANALYSIS

(ZAF CORRECTIONS VIA MAGIC $V$ )
}

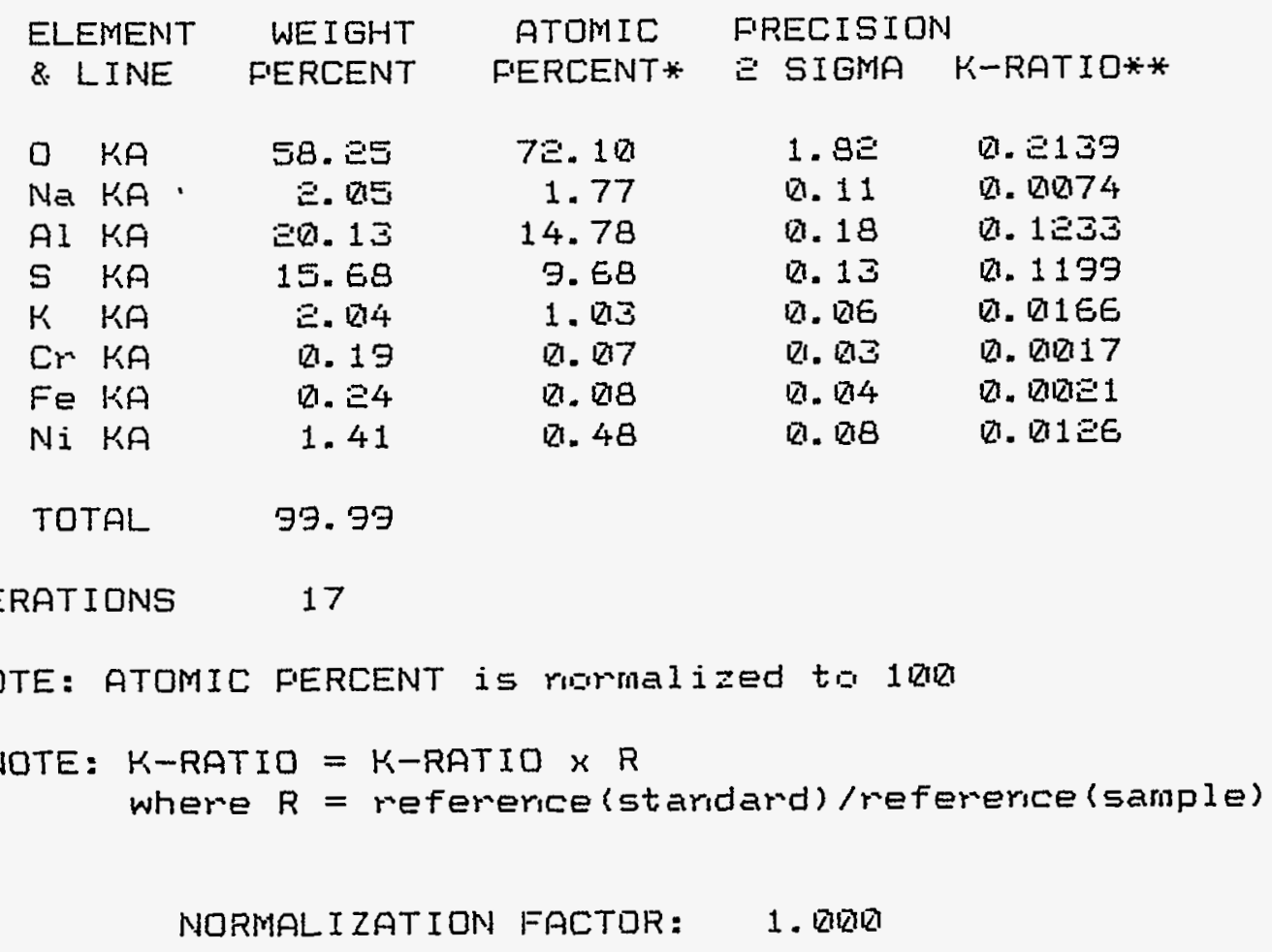


Table 7. (continued).

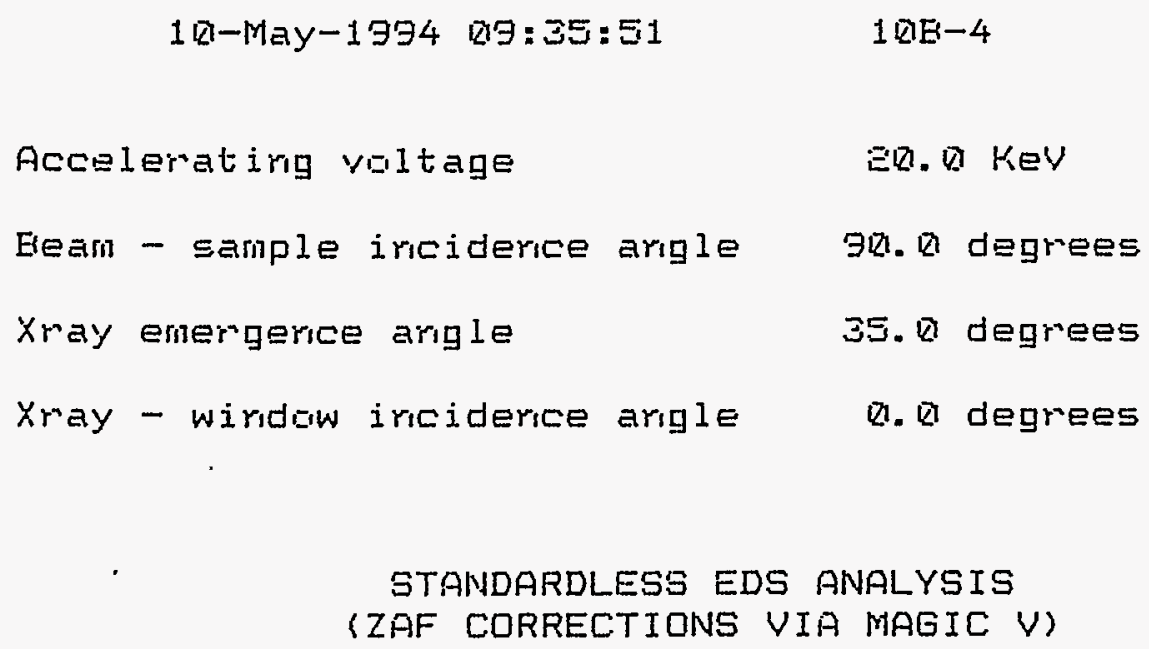

$\begin{array}{lccl}\text { ELEMENT } & \text { WEIGHT } & \text { ATOMIC } & \text { FRECISION } \\ \text { \& LINE } & \text { F'ERCENT } & \text { FERCENT* E SIGMA K-RATIO** }\end{array}$

\begin{tabular}{|c|c|c|c|c|c|}
\hline 口 & $K A$ & 47.18 & 73.98 & 0.38 & Q. 1631 \\
\hline $\mathrm{Na}$ & $K A$ & 1.75 & 1.91 & ㅁ. 14 & ㅁ. प1Q15 \\
\hline 5 & $K A$ & $\Xi \square . \Delta B$ & 15.71 & Q. 17 & ㅁ. 1548 \\
\hline$K$ & $K A$ & E. 49 & $1.6 \square$ & D. 218 & 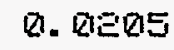 \\
\hline $\mathrm{Ca}$ & $K A$ & 3.17 & 1.99 & Q. 818 & Q. $0: 3 \Delta$ \\
\hline$Y$ & LA & $E .7 E$ & ฉ. 78 & ㅁ. 12 & Q1. 8197 \\
\hline $\mathrm{Ce}$ & LA & EE. 57 & 4.874 & Q & Q \\
\hline
\end{tabular}

TOTAL 1QRZI. BQR

ITERATIONS 13

*NOTE: ATOMIC FERCENT is rumalized to 1 QR

**NOTE: K-RATIO $=$ K-RATIO $\times R$

where $R=$ refererice (staridard)/reference (sample)

NORMALIZATION FACTOR: 1. QRZIQ 
Table 7. (continued).

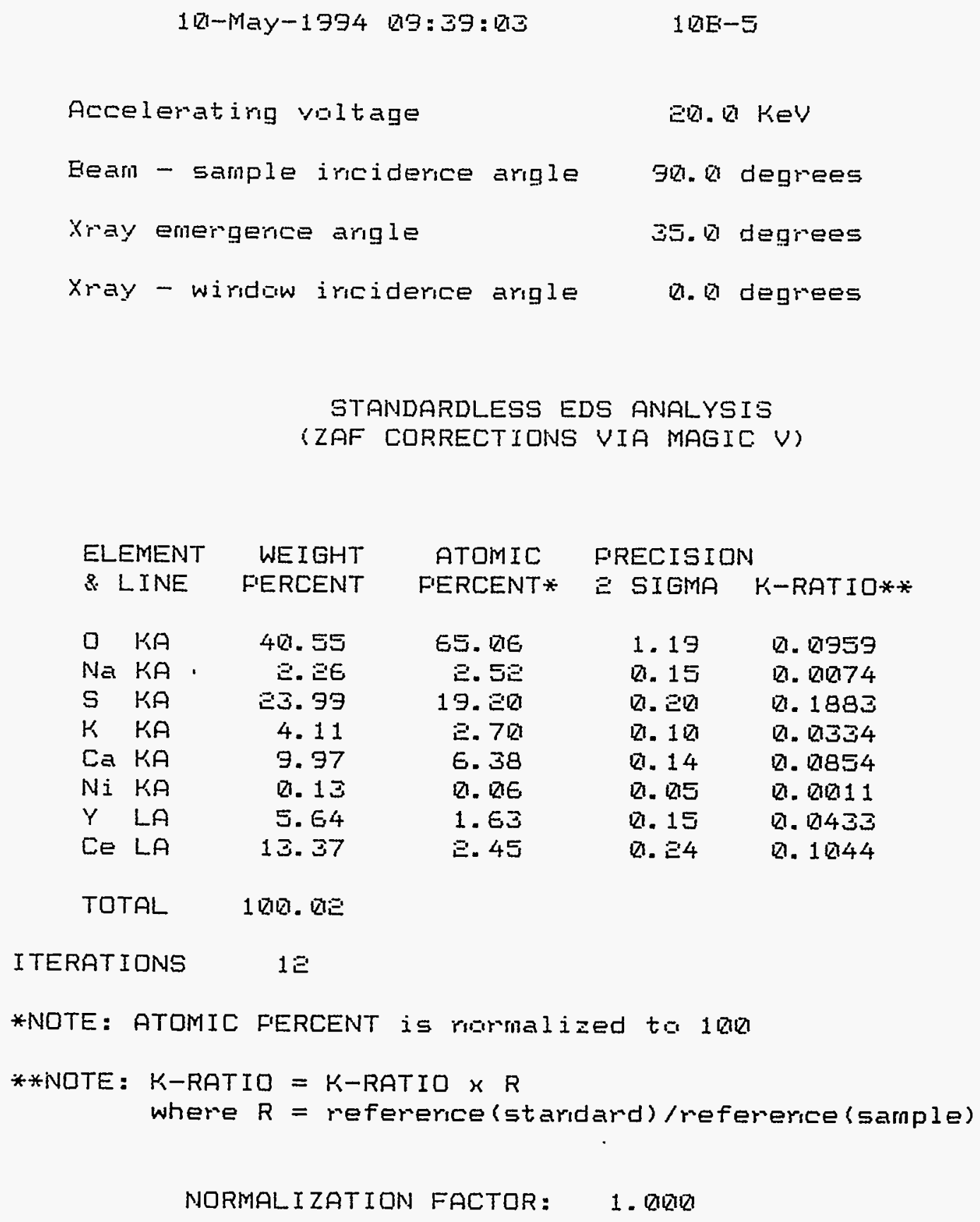


Table 7. (continued).

$\begin{array}{ll}\text { 1D-May-1994 Q19:41:10 } & 10 \mathrm{~B}-\mathrm{E} \\ \text { Acceleratirg voltage } & \text { ED. Q KeV } \\ \text { Eeam - Eample iriciderice argle } & 90.0 \text { degrees } \\ \text { Xray emergerice argle } & \text { J5. Q degrees } \\ \text { Xray - wiridow inciderice argle } & \text { Q. Q degrees }\end{array}$

STANDARDLESS EDS ANALYSIS

(ZAF CORRECTIONS VIA MAGIC $V$ )

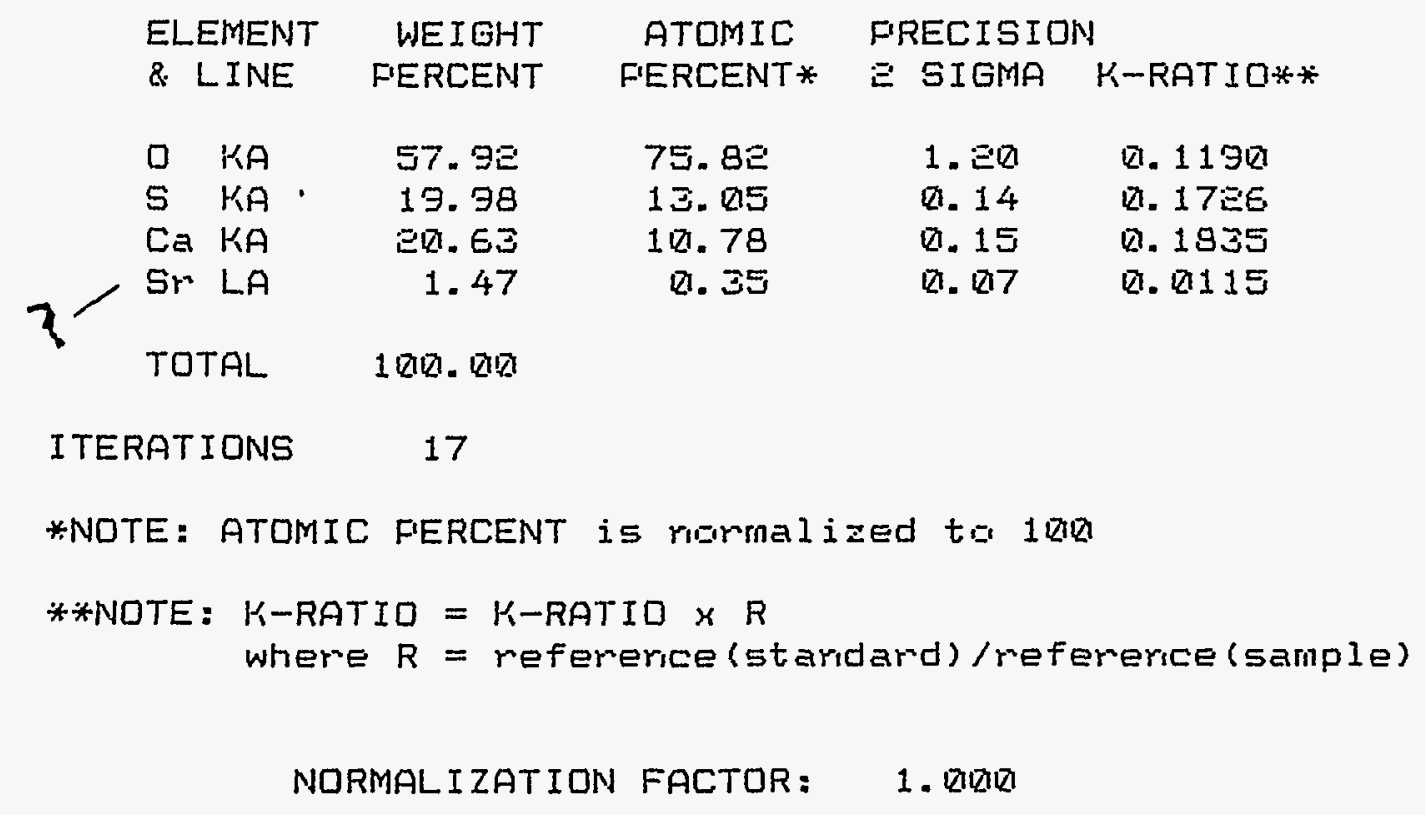


Table 7. (continued).

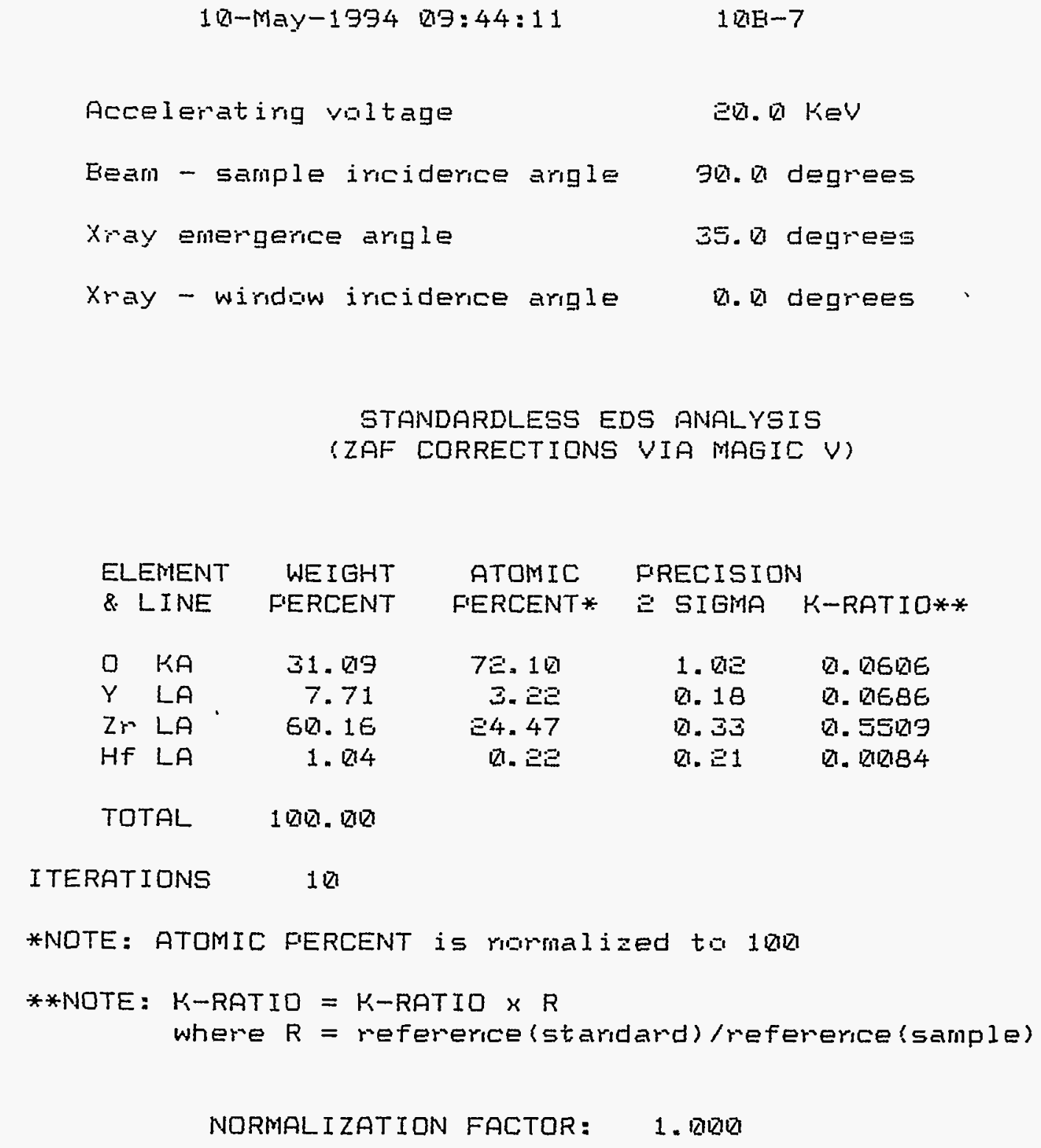


Table 7. (continued).

$$
101-\text { May-1994 09:46:16 10E-8 }
$$

$$
\begin{array}{ll}
\text { Accelerating valtage } & \text { E0. } \\
\text { Eeam - Sample inciderice angle } & 90.0 \text { degrees } \\
\text { Xray emergence angle } & 35.0 \text { degrees } \\
\text { Xray - window incidence angle } & 0.0 \text { degrees }
\end{array}
$$

STANDARDLESS EDS ANALYSIS

(ZAF CORRECTIONS VIA MAGIC $V$ )

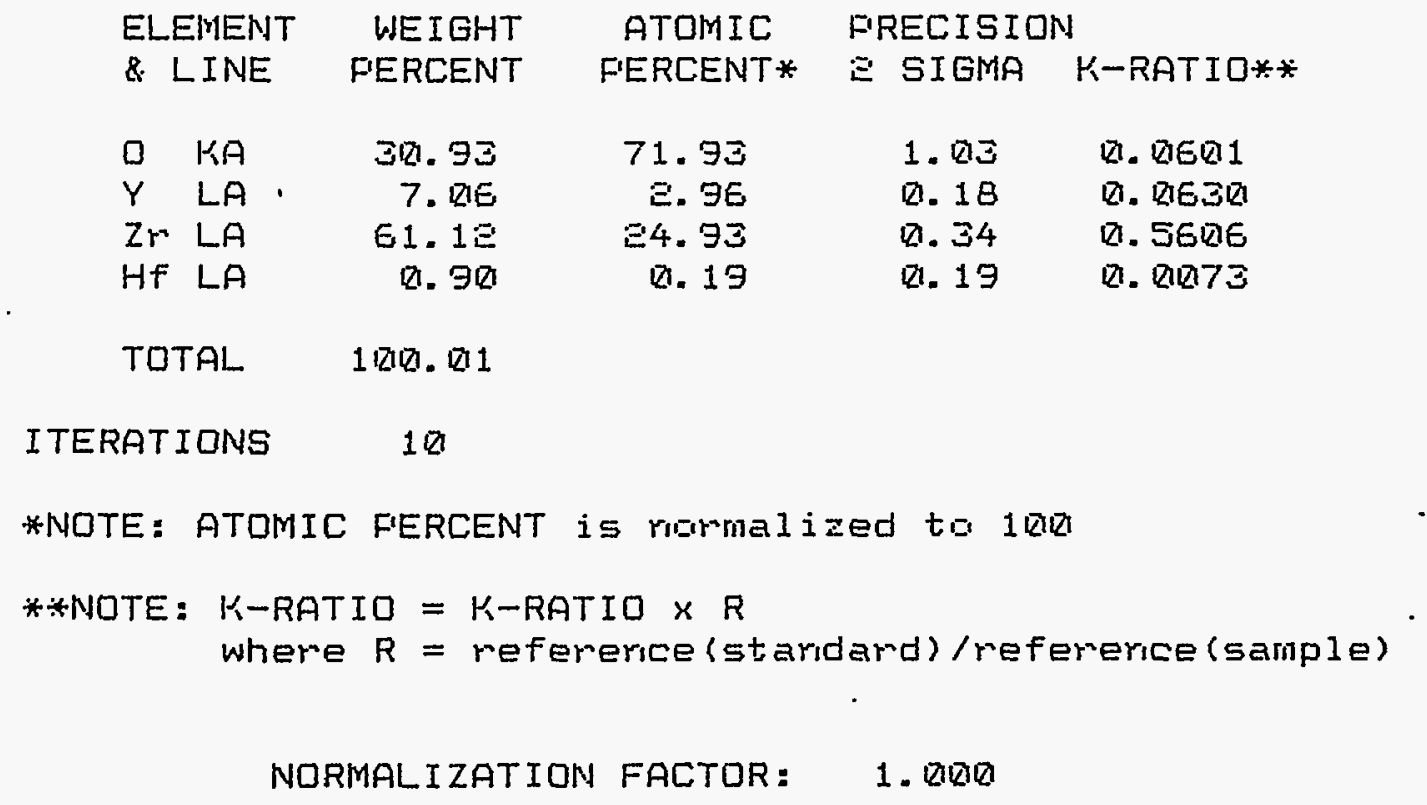


Table 7. (continued).

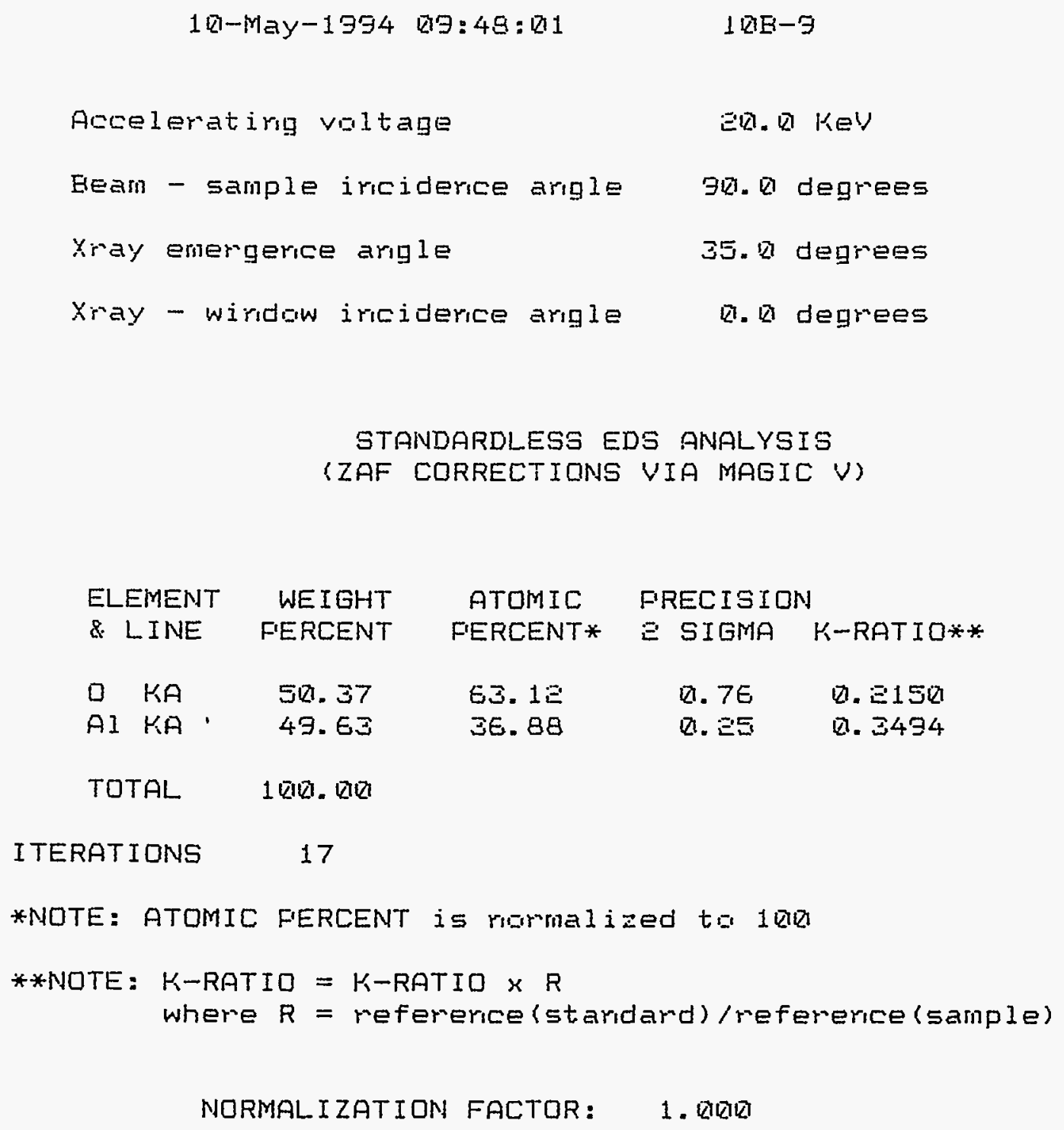


Table 7. (continued).

\begin{tabular}{|c|c|}
\hline $18-$ May-1994 1Q1: घE: $4 \varepsilon$ & $12 \mathrm{BB}-1 \mathrm{Q}$ \\
\hline Accelerating voltage & EQ $.7 \mathrm{KEV}$ \\
\hline Eeam - sample inciderice angle & 90. Q degrees \\
\hline Xray emergerice arigle & 35.01 degrees \\
\hline Xray - wirudow inciderice angle & Q. $Q$ degrees \\
\hline
\end{tabular}

STANDARDLESS EDS ANALYSIS
(ZAF CORRECTIONS VIA MAGIC $U$ )

ELEMENT WEIGHT
\& LINE FTOMIC

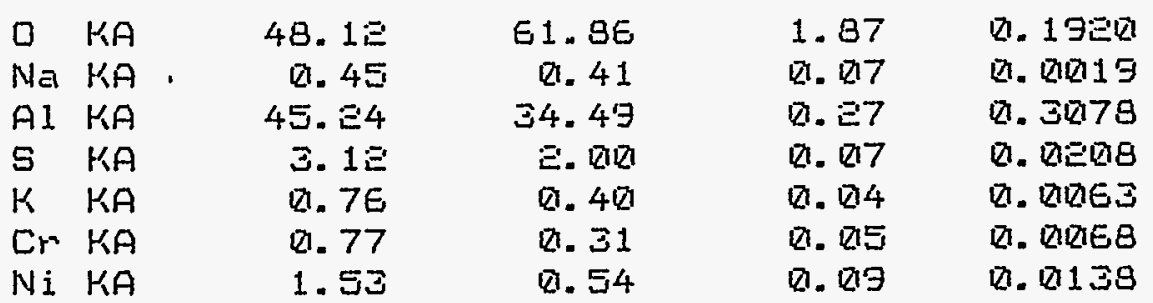

TOTAL $\quad 99.99$

ITERATIONS $\quad 14$

*NOTE: ATOMIC FERCENT is rommalized to 1 RU

**NOTE: K-RATIO $=K-R A T I O ~ * R$

where $R=$ refererice (staridard)/refererice (sample)

NORMALIZATION FACTOR: 1. QRQR 
Table 7. (continued).

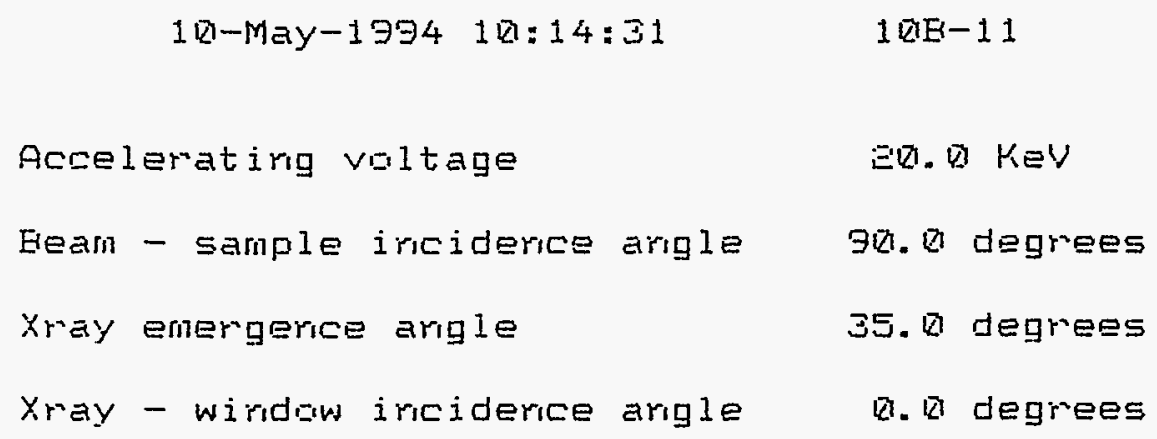

STANDARDLESS EDS ANALYSIS

(ZAF CORRECTIONS VIA MAGIC $V$ )

\begin{tabular}{|c|c|c|c|c|c|}
\hline \multicolumn{2}{|c|}{ ELEMENT } & WEIGHT & ATOMIC & \multicolumn{2}{|c|}{ FRECISION } \\
\hline 8 & INE & FERCENT & FERCENT* & E SIGMA & $K-$ RATIO \\
\hline 口 & $K A$ & $\Xi \Xi .97$ & 61.95 & 2.48 & 0.84208 \\
\hline A] & KA & 1.013 & 1. 65 & 81.827 & 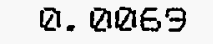 \\
\hline $\mathrm{Cr}$ & $K A$ & Q.:24 & Q. $\Xi \square$ & $\nabla . \nabla \nabla \epsilon$ & 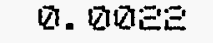 \\
\hline$F_{E}$ & $K A$ & ㅁ. $: 24$ & 0.19 & Q. DE & Q. Qnazes \\
\hline $\mathrm{Ni}$ & $K A$ & 1.77 & 1.30 & ధ. 1こ & Q. $\$ 177$ \\
\hline Y & LA & $10 .: 3$ & 5. 810 & Q1. 13 & Q. 28918 \\
\hline $\mathrm{Zr}$ & LA & EE. 14 & 29.39 & 0.05 & Q $.5 \in E D$ \\
\hline & LA & 1. $\Xi \Xi$ & Q. $3 \Xi$ & ฉ. シコ & Q. 01019 \\
\hline
\end{tabular}

TOTAL 100. QRQR

ITERATIONS $\quad 3$

*NOTE: ATOMIC FERCENT is rummalized ta 1 QR

**NOTE: K-RATIO $=K$-RATIO $\times R$

where $R=$ reference (staridard)/mefererice (sample)

NORMALIZATION FACTOR: 1. RUOB 
Table 7. (continued).

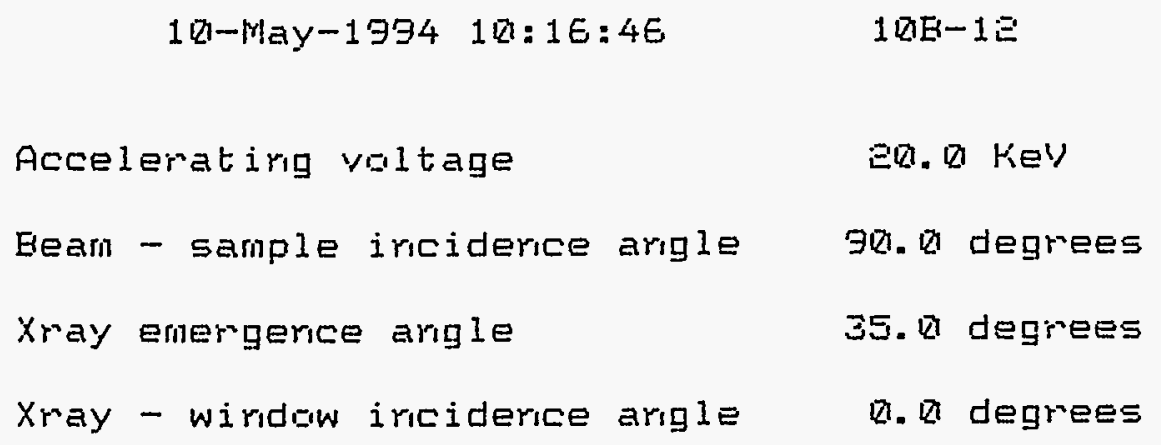

STANDARDLESS EDS ANALYSIS

(ZAF CORRECTIONS VIA MAGIC $V$ )

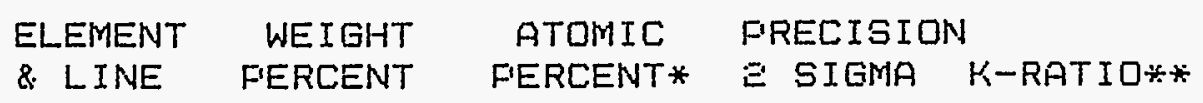

\begin{tabular}{|c|c|c|c|c|c|}
\hline$\square$ & $K A$ & ЕЕ. هక & 44.77 & 1. ت1 & 0.0779 \\
\hline$A 1$ & $K A$ & 3.55 & 4. 27 & Q1. 13 & Q1. 2150 \\
\hline$S i$ & $K A$ & 1.15 & 1. 33 & 0.077 & Q. $\square \square Q \square=$ \\
\hline 5 & $K A$ & 9. 14 & 9. $\Xi E$ & Q2. 13 & ฉ. \\
\hline $\mathrm{Cl}$ & $K A$ & 11.71 & 18.73 & 8. 14 & ฉ. 2858 \\
\hline $\mathrm{Cr}$ & $K A$ & 9.89 & 5.68 & Q. 15 & Q. $\square B E S$ \\
\hline i & $K A$ & 43.38 & $\Xi \Xi .96$ & Q. 41 & 8.4853 \\
\hline
\end{tabular}

TOTAL $\quad 99.99$

ITERATIONS 7

*NOTE: ATOMIC FERCENT is rumalized to 1 RQ

**NOTE: $K$-RATIO $=K$-RATIO $\times R$

where $R$ = reference (staridard)/reference (sample)

NORMALIZATION FACTOR: 1. DIRO 
Table 7. (continued).

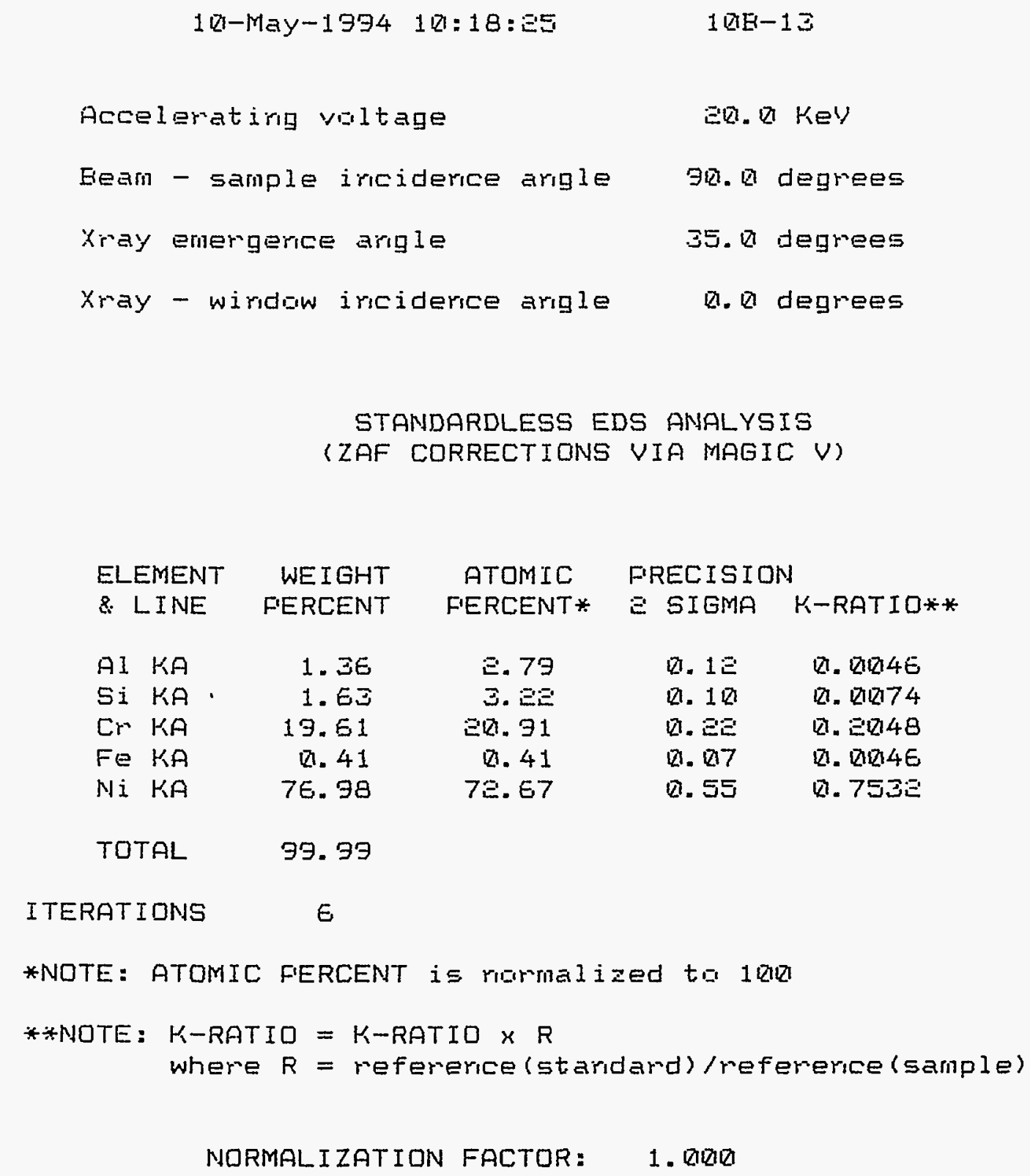


Table 7. (continued).

$$
18-M a y-1994 \quad 10: 20: 14 \quad 10 E-14
$$

\begin{tabular}{|c|c|c|c|}
\hline Acce 1 & lematirg voltage & & EQ. Q K KEV \\
\hline EEam & - sample iriciderice & arigle & $90 . \bar{l}$ degrees \\
\hline Xray & emergence arigle & & 35. Q degriees \\
\hline y & - wiridow iriciderice & arigle & Q. 8 degrees \\
\hline
\end{tabular}

STANDARDLESS EDS ANALYSIS
(ZAF CORRECTIDNS VIA MAGIC $V$ )

$\begin{array}{lccc}\text { ELEMENT } & \text { WEIGHT } & \text { ATOMIC } & \text { FRECISION } \\ \& \text { LINE } & \text { FERCENT } & \text { FERCENT* } & \text { É SIGMA K-RATID** }\end{array}$

\begin{tabular}{|c|c|c|c|c|}
\hline $\mathrm{Al} \mathrm{KA}$ & 8. $3 \Xi$ & 15.87 & Q1. $\Xi 0$ & ㅁ. . \\
\hline Si KA & 1.87 & 3.41 & Q. 10 & Q. В12184 \\
\hline $\mathrm{Cr} \quad K A$ & 18. $3 \Xi$ & 18.1已 & จ. ت1 & Q. 1891 \\
\hline Fe $\mathrm{KA}$ & ฤ. $\Xi 8$ & ㅁ. $\Xi E$ & Q1. $\nabla E$ & ฉ1. ロИロコ1 \\
\hline$N i K A$ & $71 . \Xi$ & $E=.34$ & ه. 53 & 8. 6934 \\
\hline
\end{tabular}

TOTAL 18R. Q1

ITERATIINS $\quad E$

*NOTE: ATOMIC FERCENT is romalized to 1 QR

**NOTE: K-RATIO = K-RATIO $\times R$

where $R=$ refererice (staridard)/refererice (sample)

NORMALIZATION FACTOR: 1. MQRO 
Table 7. (continued).

\begin{tabular}{|c|c|c|c|}
\hline & 10-May-1934 101: & 18 & $10 \mathrm{~B}-15$ \\
\hline Accel & Ieratirg voltage & & ER. Q K KEV \\
\hline BEam & - sample iriciderce & arigle & 90. Q degrees \\
\hline Xray & emergence argle & & 35.8 degrees \\
\hline & - wiridaw iriciderice & arigle & Q. 8 degr \\
\hline
\end{tabular}

STANDARDLESS EDS ANALYSTS

(ZAF CORRECTIONS VIA MAGIC $V$ )

\begin{tabular}{|c|c|c|c|c|c|}
\hline \multicolumn{2}{|c|}{ ELEMENT } & WEIGHT & ATOMIC & \multicolumn{2}{|c|}{ PRECISION } \\
\hline & LINE & F'ERCENT & F'ERCENT* & $\Xi$ SIGMA & $K-$ RATIO** \\
\hline 0 & $K A$ & $35.7 \Xi$ & 60.71 & 1.19 & Q. $\Xi 149$ \\
\hline Al & KA & $1 \Xi .94$ & 13.08 & [1. 19 & Q. $Q Q_{1} \in \nabla_{n}$ \\
\hline $\mathrm{Cl}$ & $K A$ & Q1. $4 E$ & Q1. $3 E$ & Q1. 124 & 囚. ВRВ \\
\hline $\mathrm{Cr}^{-}$ & $K A$ & 33.45 & 17.55 & ㅁ. $\Xi 7$ & Q1. 3149 \\
\hline $\mathrm{Fe}$ & $K A$ & D. $3 \Xi$ & Q. 16 & Q. $\nabla E$ & 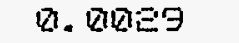 \\
\hline $\mathrm{Ni}$ & $K A$ & 17.12 & 7.95 & Q. 27 & 0.1556 \\
\hline TO & & 1812 & & & \\
\hline
\end{tabular}

ITERATIONS $\quad \exists$

*NOTE: ATOMIC FERCENT is Murmalized to 1 gu

**NOTE: K-RATIO $=K$ K-RATIO $\times R$

where $R$ = refererice (staridard)/refererice (sample)

NORMALIZATION FACTOR: 1. BIER 
Table 7. (continued).

$$
\begin{aligned}
& 10-M a y-1994 \quad 10: E E: 015 \\
& \text { Accelerating voltage Zu. ReV } \\
& \text { Eeam - sample incidence argle } 90.0 \text { degrees } \\
& \text { Xray energerce argle } 35.0 \text { degrees } \\
& \text { Xray - window inciderice angle } 0.0 \text { degrees }
\end{aligned}
$$$$
\text { STANDARDLESS EDS ANALYSIS }
$$$$
\text { (ZAF CORRELTIIONS VIA MAGIC } V \text { ) }
$$

$\begin{array}{lrll}\text { ELEMENT } & \text { WEIGHT } & \text { ATOMIC } & \text { FRECISION } \\ \text { \& LINE } & \text { FERCENT FERCENT* E SIGM HA HATIO*** }\end{array}$

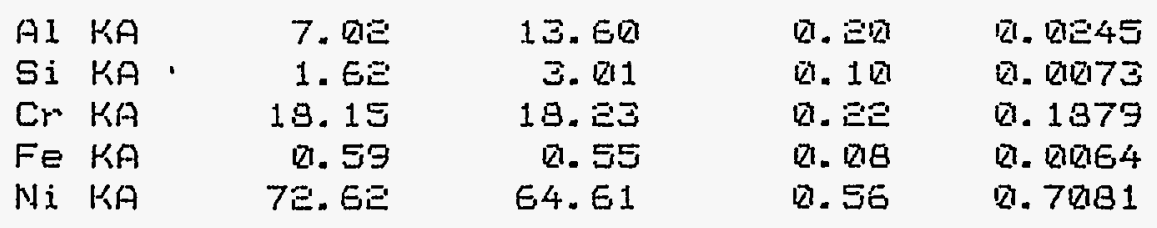

TOTAL 1RIRI. QRQR

ITERATIONS $\quad E$

*NOTE: ATOMIC FERCENT, is rommalized to 1 QU

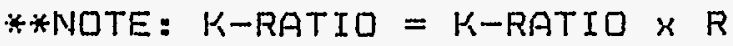

where $R$ = refererice (stardard)/reference (sample)

NORMALIZATION FACTOR: 1. RQRT 


\subsubsection{Coating 083-4}

An overall view of a successful coating (083-4) is shown in Figure 10. This coating resisted the simulated waste stream with no apparent coating damage visible under light or scanning electron microscopy. The thermally induced cracks will act as a pathway for the corrosive species to penetrate the coating and the key question is whether the coating will then resist spalling from formation of corrosion products if the corrosive environment reacts with the coating at the bottom of the cracks. The coating was scanned for cracks in the SEM and a typical one (crack 3, Figure 22) was analyzed and the chemistry of the areas tabulated in Table 8. The spectra from these cracked areas was distorted in varying amounts due to the fact that some of the emitted electrons from the analysis areas will be absorbed on the walls of the cracks. The electrons from light elements such as aluminum, sodium and oxygen would be preferentially absorbed compared to the electrons from heavier elements such as nickel or zinc. This would result in the spectra for these elements not being fully developed thereby giving a lower concentration value than is really the case. Note that this coupon is label as $942 \mathrm{~T} 2 \# 4$ on the photomicrograph.

Area 1 The EDS spectrum for this area shows a high level of titanium with aluminum and oxygen present. This spot was located in the crack which then would distort the spectrum. The values of aluminum and oxygen were probably higher than the values shown in Table 8.

Area 2 Titanium, aluminum, and oxygen are present here along with chlorine. The spectrum was slightly distorted and the amounts of oxygen and aluminum may be higher. Carbon was also detected but the EDS technique cannot quantify this element very well.

Area 3 This area also shows titanium, aluminum, and oxygen with some distortion of the spectra. The aluminum and oxygen values are probably low.

The following analysis is shown on Figure 23 and in Table 9.

Area 4 The analysis area measures the elements present in the surface deposit found on this coupon. There is a large amount of the radionuclide surrogate cerium present with lead and zinc also detected. The nickel,aluminum, and zirconium present are probably corrosion products from the reaction of the test fluid with other coupons.

Area 5 The chemical analysis from this area shows titanium and oxygen which form the $\mathrm{TiO}_{2}$ coating.

Area 6 This area has titanium and aluminum which would be indicative of the Ti- $6 \mathrm{Al}-4 \mathrm{~V}$ bond layer but no vanadium was detected. A large amount of nitrogen was detected.

Area 7 This area is well into the base metal and shows the expected spectra for titanium. There is also a large amount of nitrogen present. 


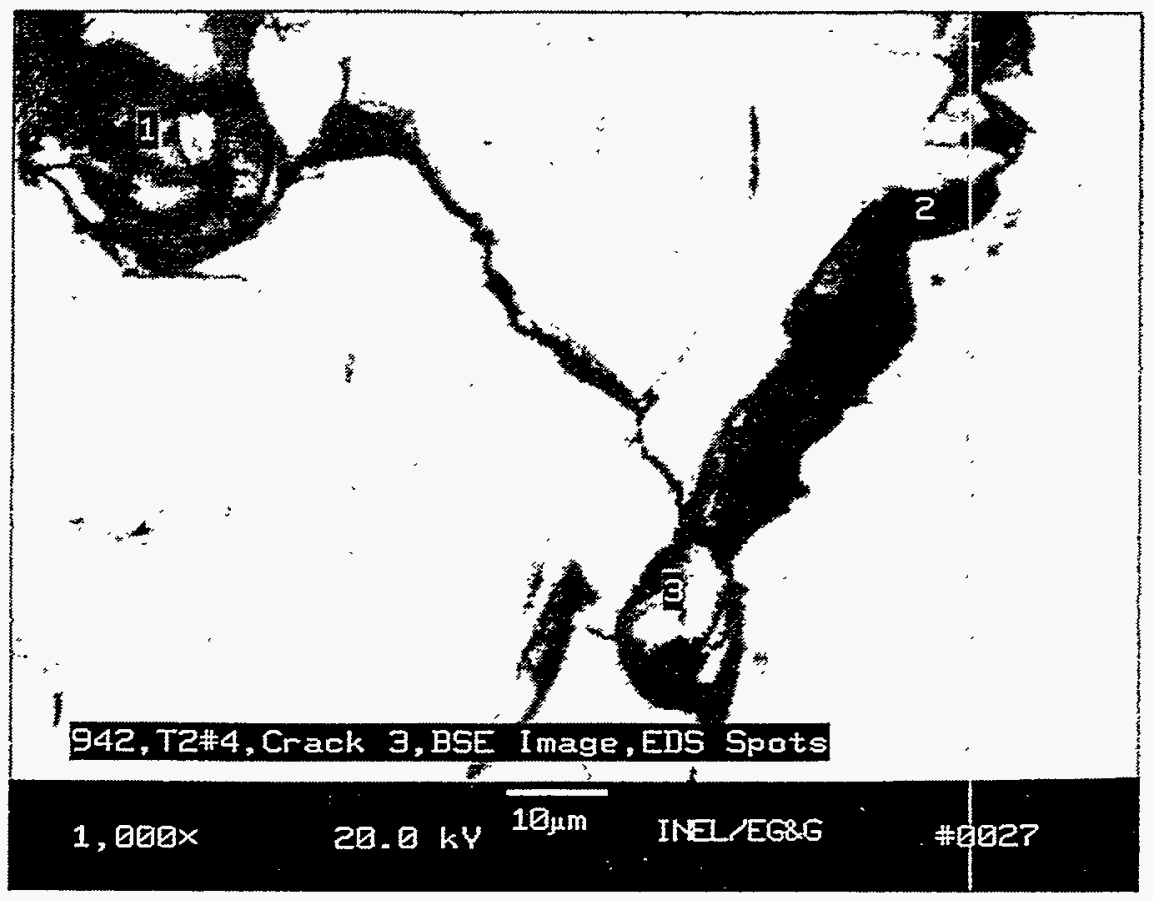

Figure 22. $1000 \times$ view of $083-4$. 
Table 8. Results of analysis of areas shown in Figure 22.

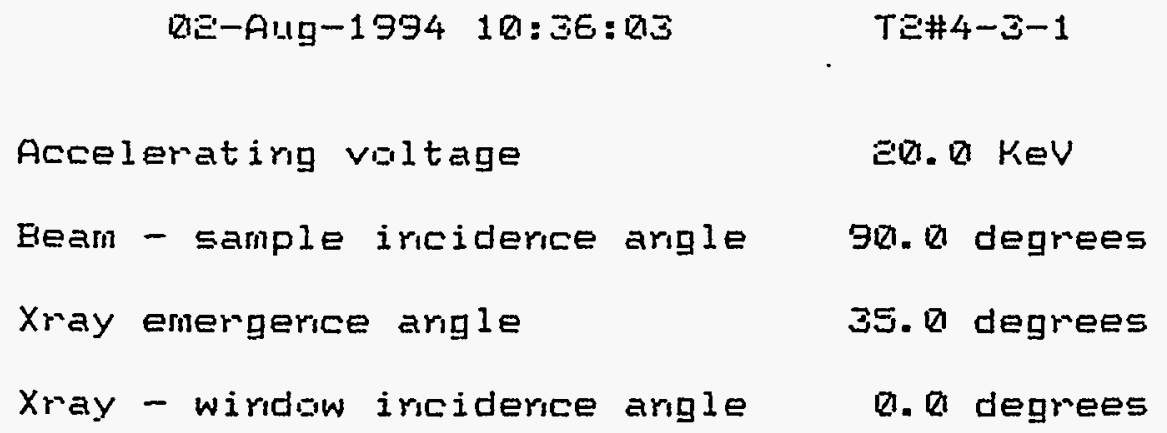

\title{
STANDARDLESS EDS ANALYSIS
}

(ZAF CORRECTIONS VIA MAGIC $V$ )

\author{
ELEMENT WEIGHT ATOMIC FRECISION \\ \&. LINE FERCENT FERCENT* Z SIGMA K-RATIO**

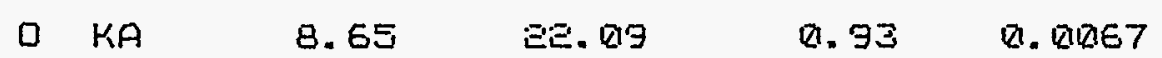

Al KA Q. Q13 Q. Q15 Q. Q1 1 Q. QRQRE \\ $\begin{array}{lllll}\text { Ti KA } & 91.31 & 77.96 & 0.48 & 0.9001\end{array}$ \\ TOTAL $\quad 99.99$ \\ ITERATIONS 10 \\ *NOTE: ATOMIC FERCENT is nommalized ta 180 \\ **NOTE: K-RATIO $=K-R A T I O \times R$ \\ where $R=$ reference (standard)/reference (sample) \\ NORMALIZATION FACTOR: 1. QUQR
}


Table 8. (continued).

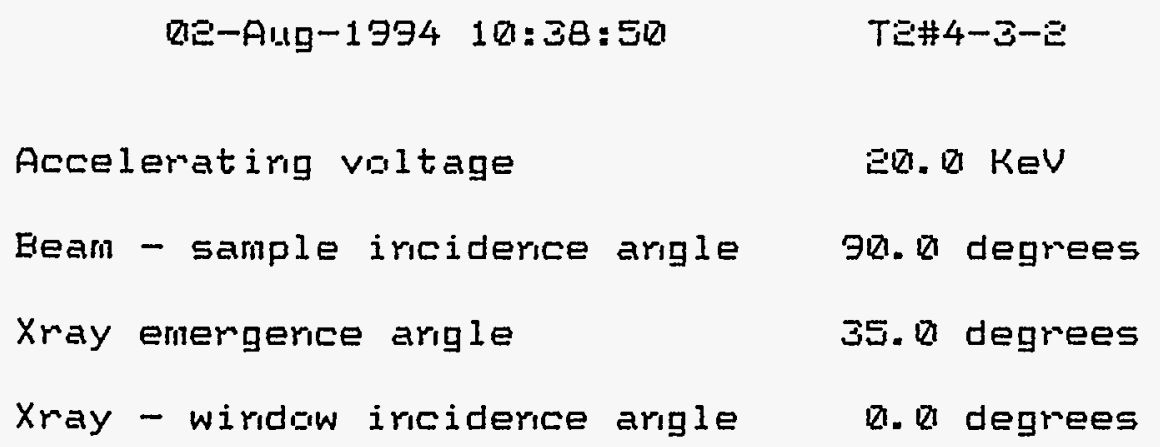

STANDARDLESS EDS ANALYSIS
(ZAF CORRECTIONS VIA MAGIC $V$ )

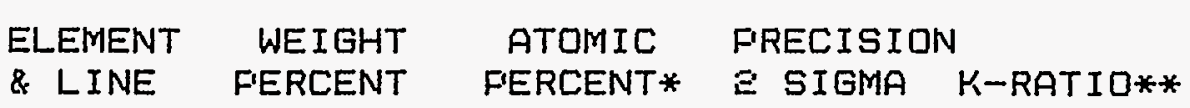

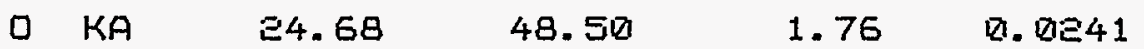

Al $K A$. E. 24 E.E1 Q.1E Q.01EZ

$\begin{array}{lllll}\mathrm{K} A & 4.04 & 3.58 & 0.11 & 0.01370\end{array}$

$\begin{array}{lllll}\mathrm{Ti} K A & 69.015 & 45.32 & 0.49 & 0.6534\end{array}$

TOTAL $\quad 107.01$

ITERATIONS 18

*NOTE: ATOMIC FERCENT is mommalized ta 1 BR

**NOTE: K-RATIQ $=K$-RATIO $\times R$

where $R=$ reference (staridard)/reference (sample)

NORMALIZATION FACTOR: 1. QRQD 
Table 8. (continued).

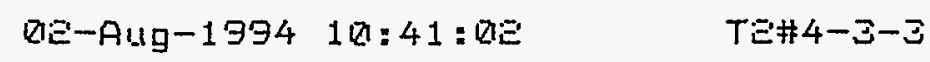

$\begin{array}{lc}\text { Accelemating valtage } & \Xi 0.0 \mathrm{KeV} \\ \text { Beam - sample iricidence argle } & 90.0 \text { degrees } \\ \text { Xray emergence angle } & 35.0 \text { degrees } \\ \text { Xray - window irciderice argle } & \square .0 \text { degrees }\end{array}$

STANDARDLESS EDS ANALYSIS

(ZAF CORRECTIONS VIA MAGIC $V$ )

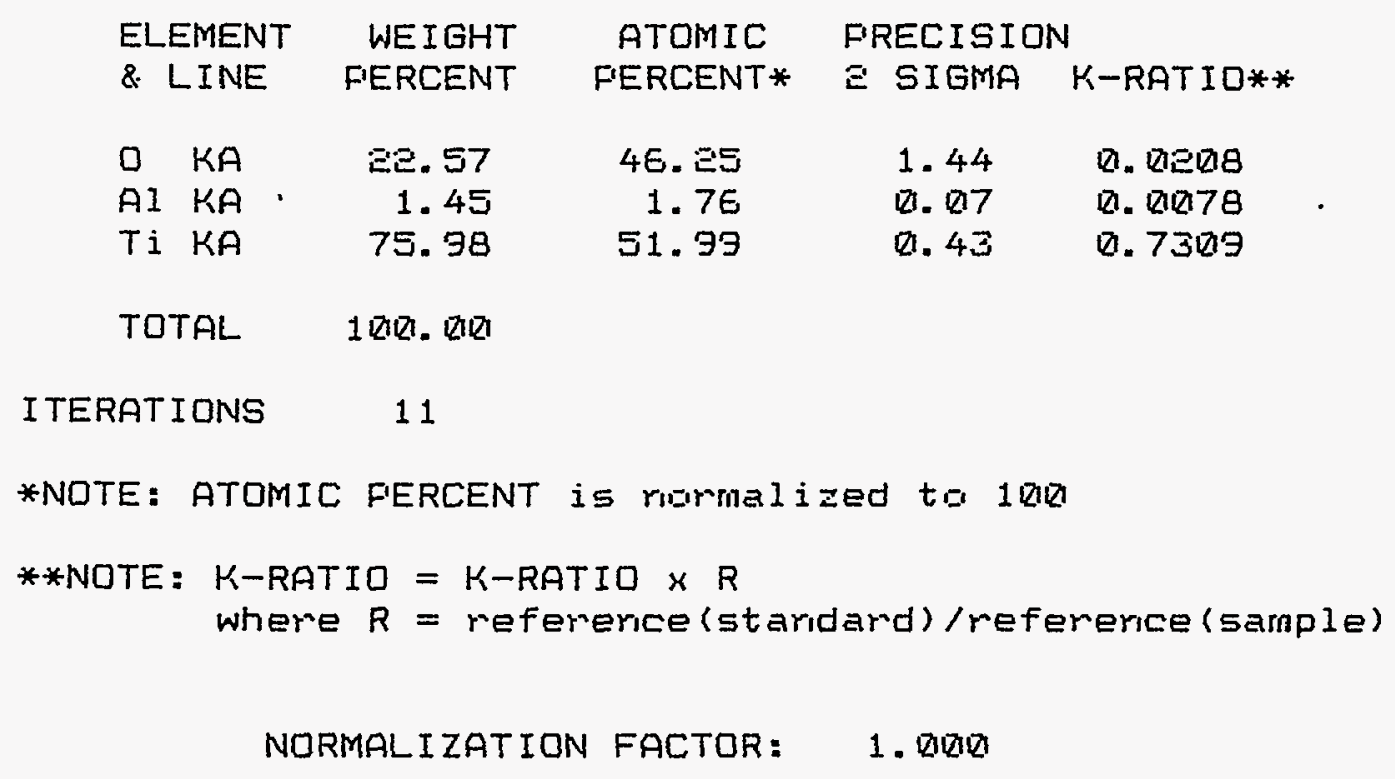




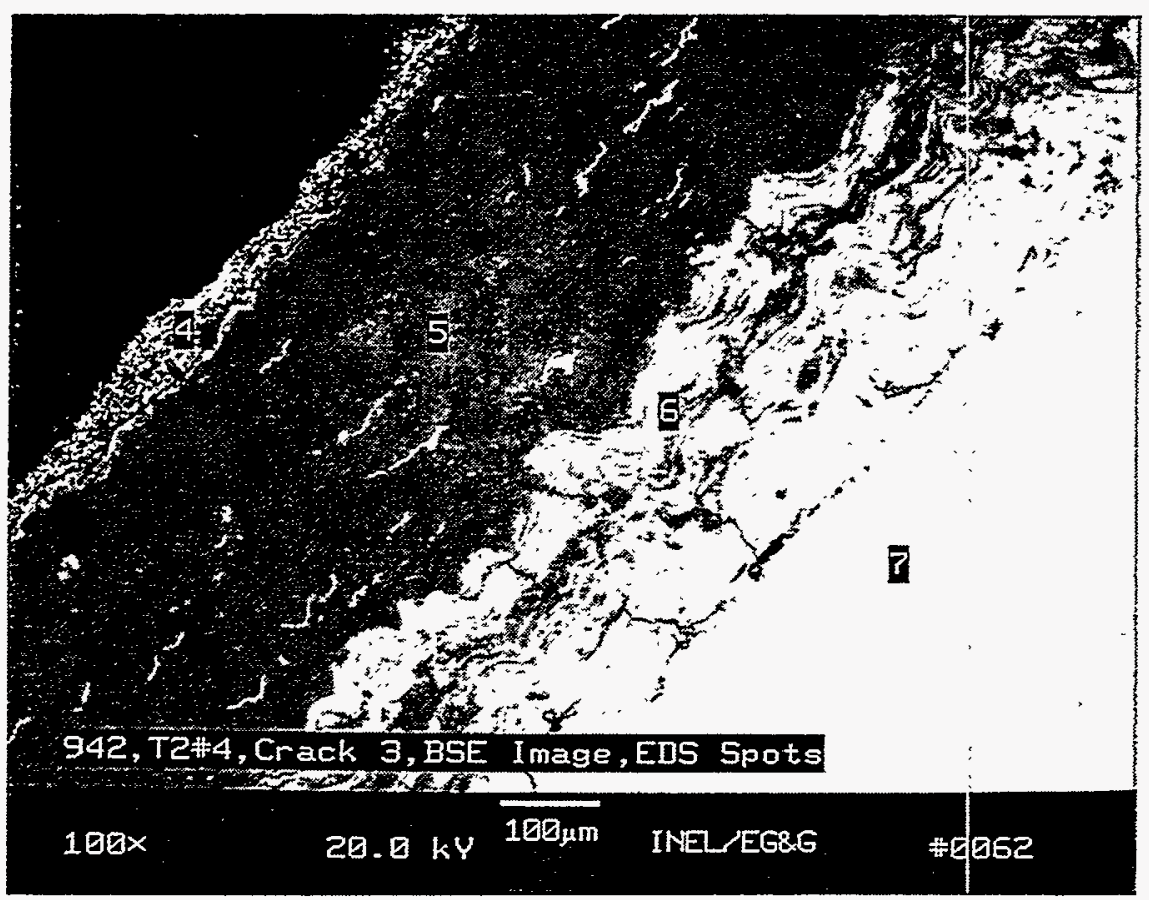

Figure 23. $100 \times$ view of $083-4$. 
Table 9. Results of analysis of areas shown in Figure 23.

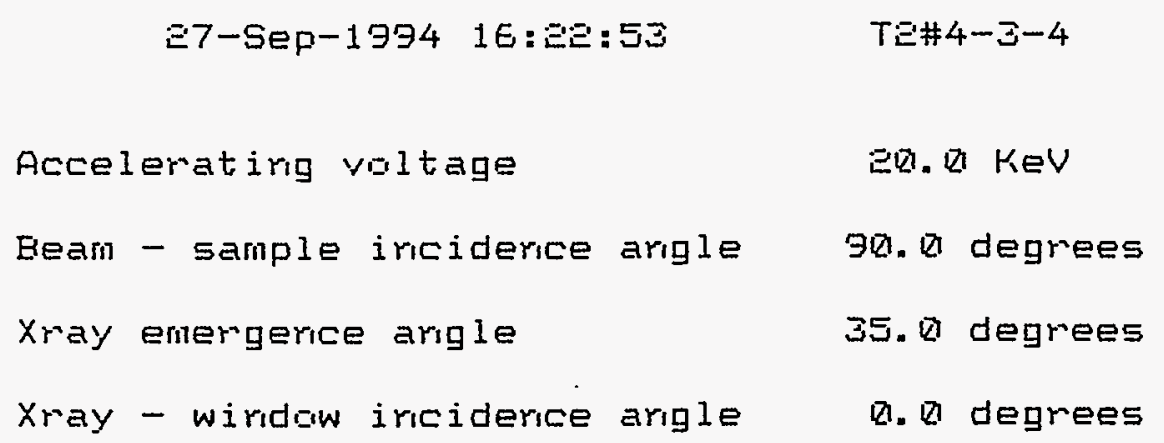

STANDARDLESS EDS ANALYSIS
(ZAF CORRECTIONS VIA MAGIC $V$ )

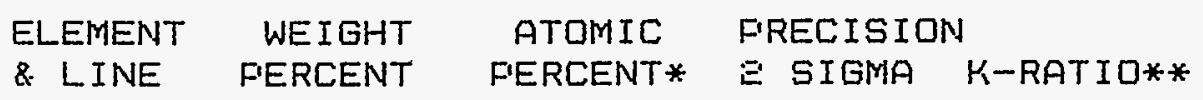

\begin{tabular}{|c|c|c|c|c|}
\hline$D \quad M A$ & 27.36 & 74.89 & 0.83 & ㅁ. 1341 \\
\hline Al KA & 0.45 & 0.71 & Q2. 11 & Q. $\square \square 17$ \\
\hline $\mathrm{Ca} K A$ & Q1. 47 & 0.51 & Q1. .127 & B. $\operatorname{Qn} \square 44$ \\
\hline $\mathrm{Ni} K A$ & 4.85 & 3.58 & ㅁ‥ 코 & Q. $847 \Xi$ \\
\hline $\mathrm{Zn} K A$ & $3.4 \Xi$ & こ. $\Xi 7$ & $\square . \Xi 7$ & ロ. ロココヨ \\
\hline$Z_{r} \quad L A$ & $\Xi . \Xi \exists$ & 1. 19 & $Q 2.1 Q 2$ & 0.0148 \\
\hline Ce LA & 49.45 & 15.29 & 87.49 & 12.4359 \\
\hline F' MA & 11.70 & 2.45 & 0.67 & Q. \\
\hline
\end{tabular}

TOTAL $\quad 99.99$

ITERATIONS $\quad 9$

*NOTE: ATOMIC FERCENT is rummalized to $18 Q$

**NOTE: K-RATIO $=K-$ RATIO $\times R$

where $R=$ reference (staridard)/reference (sample)

NORMALIZATION FACTOR: 1. RZIZI 
Table 9. (continued).

$$
\text { E7-Sep-1994 1E:こ5:DE TE\#4-3-5 }
$$

$$
\begin{array}{lc}
\text { Accelerating voltage } & 00.0 \mathrm{KeV} \\
\text { Eeam - sample incidence argle } & 90.0 \text { degrees } \\
\text { Xray emergence angle } & 35.0 \text { degrees } \\
\text { Xray - windaw inciderice argle } & 0.0 \text { degrees }
\end{array}
$$

STANDARDLESS EDS ANALYSIS

(ZAF CORRECTIONS VIA MAGIC $V$ )

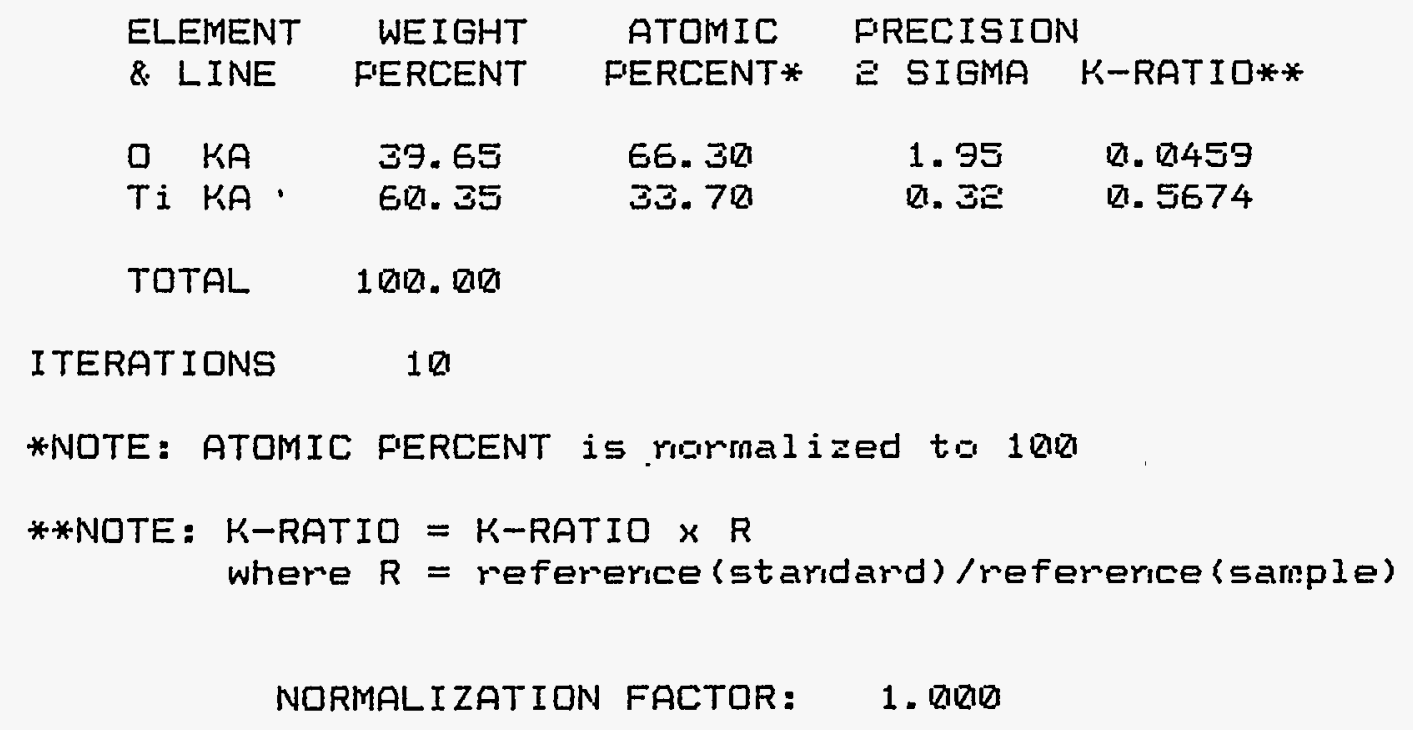


Table 9. (continued).

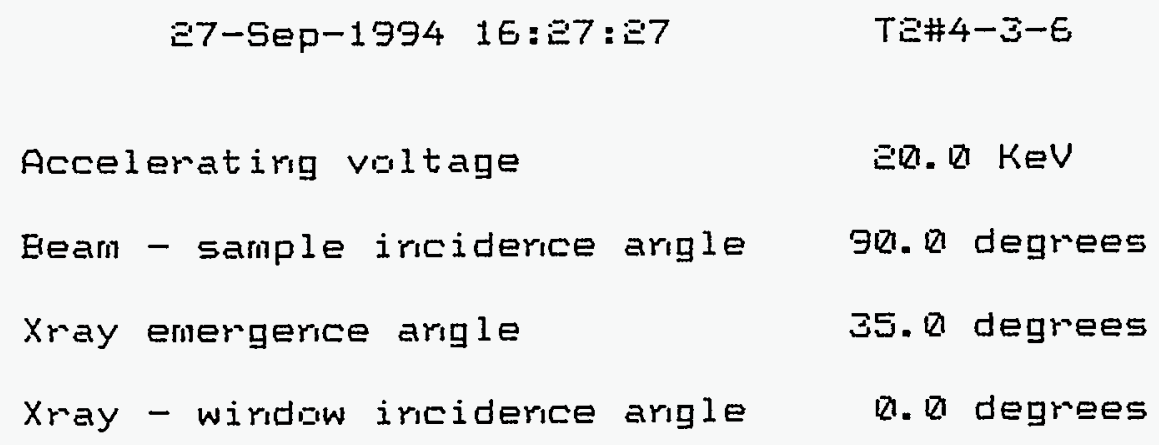

STANDARDLESS EDS ANALYSIS

(ZAF CORRECTIONS VIA MAGIC $V$ )

\begin{tabular}{|c|c|c|c|c|}
\hline ELEMENT & WEIGHT & ATOMIC & \multicolumn{2}{|c|}{ FRECISION } \\
\hline \& LINE & FEERCENT & F'ERCENT* & E SIGMA & K-RATID** \\
\hline$K A$ & $21 ., \nabla 9$ & $4 E . E \epsilon$ & Q. 63 & Q. 1319 \\
\hline$D \quad K A$ & Q. 8.2187 & Q1. Q & Q. 80 & $\square . \quad \square \square \square \square \square$ \\
\hline A1 KA & 4. $6=$ & 5.31 & 0.10 & $\nabla . \square E \in \square$ \\
\hline $\mathrm{Ti} K A$ & 73.94 & 47.83 & Q. 31 & ㅁ. 72191 \\
\hline $\mathrm{Cr}^{2} \mathrm{KA}$ & Q. 34 & ㅁ. E1 & 0.814 & 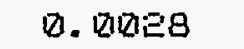 \\
\hline
\end{tabular}

TOTAL $\quad 99.99$

ITERATIONS $\quad 9$

*NOTE: ATOMIC PERCENT is rommalized to 1 QUR

**NOTE: K-RATIO $=K$-RATIO $\times R$

where $R=$ reference (staridard)/reference (sample)

NORMALIZATION FACTOR: 1. QRQR 
Table 9. (continued).

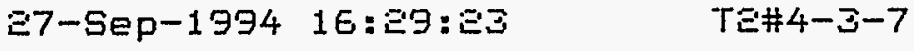

$$
\begin{aligned}
& \text { Accelerating Voltage } \mathrm{ZQ} \text { Q KeV } \\
& \text { Eearn - sample iriciderice angle } 90.0 \text { degrees } \\
& \text { Xray emergerice arigle } 35.0 \text { degrees } \\
& \text { Xray - wiridaw incidence argle Q degrees }
\end{aligned}
$$

STANDARDLESS EDS ANALYSIS

(ZAF CORRECTIONS VIA MAGIC $V$ )

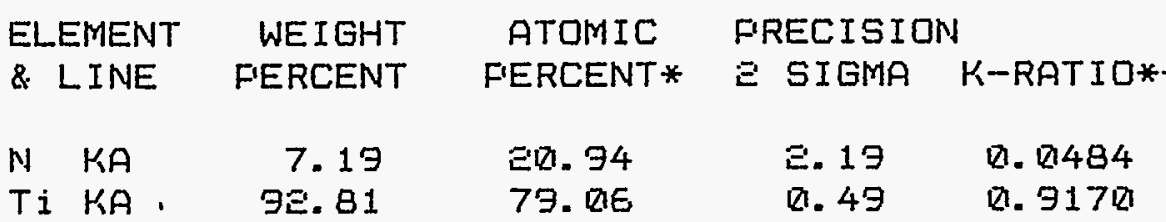

TOTAL $\quad 10 Q 8.8 Q R$

ITERATIONS 8

*NOTE: ATOMIC FERCENT is rormalized to 1 QR

**NOTE: K-RATIO = K-RATIO $K R$

where $R=$ refererice (standard)/reference (sample)

NORMALIZATION FACTOR: 1. QRZR 
A second cracked area was analyzed (Figure 24) and the results are shown in Table 10. This crack extends from the cermet layer to the base metal.

Area 1 This area exhibits the approximate chemistry of the Ti- $6 \mathrm{Al}-4 \mathrm{~V}$ bond coat with an appreciable amount of nitrogen and a small amount of iron present.

Area 2 This chemistry shows evidence of the chemistry of a mixed $\mathrm{Ti}-6 \mathrm{Al}-4 \mathrm{~V} / \mathrm{TiO}_{2}$ structure with a significant amount of nitrogen present. Iron and a small amount of silicon are also present.

Area 3 This area is basically $\mathrm{TiO}_{2}$ with aluminum, zinc, lead, and calcium as impurities.

Area 4 This is the Ti-6Al-4V bond coat with a significant nitrogen content.

Area 5 This area is next to Area 4 (bond coat) in the upper reaches of the crack. It looks like the $\mathrm{TiO}_{2}$ spectrum described earlier with impurities of lead, aluminum, and silicon.

Area 6 This area is farther down the crack near the base metal. It has all elements that would be present in the $\mathrm{Ti}-6 \mathrm{Al}-4 \mathrm{~V} / \mathrm{TiO}_{2}$ cermet layer with significant impurities such as nitrogen, silicon, zinc, and lead.

Area 7 This area shows a mixed chemistry of the Ti- $6 \mathrm{Al}-4 \mathrm{~V}$ bond coat and nitrogen.

Area 8,9 Areas 8 and 9 are on the bond coast base metal interface. It shows a $\mathrm{TiO}_{2}$ chemistry with the impurities zinc and lead present. The chemistry is not indicative of the bond layer that is Ti-6Al-4V.

Observations: This coating did not delaminate.

Various areas in the coating and the cracks perpendicular to the coating show a large amount of nitrogen pickup.

The heavy metal impurities (zinc, lead) in many cases and the radionuclide surrogate $\mathrm{Ce}$ in one case were found in the cracks. These cracks did not propagate and cause coating delamination. These elements were found in the failed areas of the other coatings.

This coating should be tested for a longer time interval to see if the impurities will continue to collect in the cracks and cause failure. 


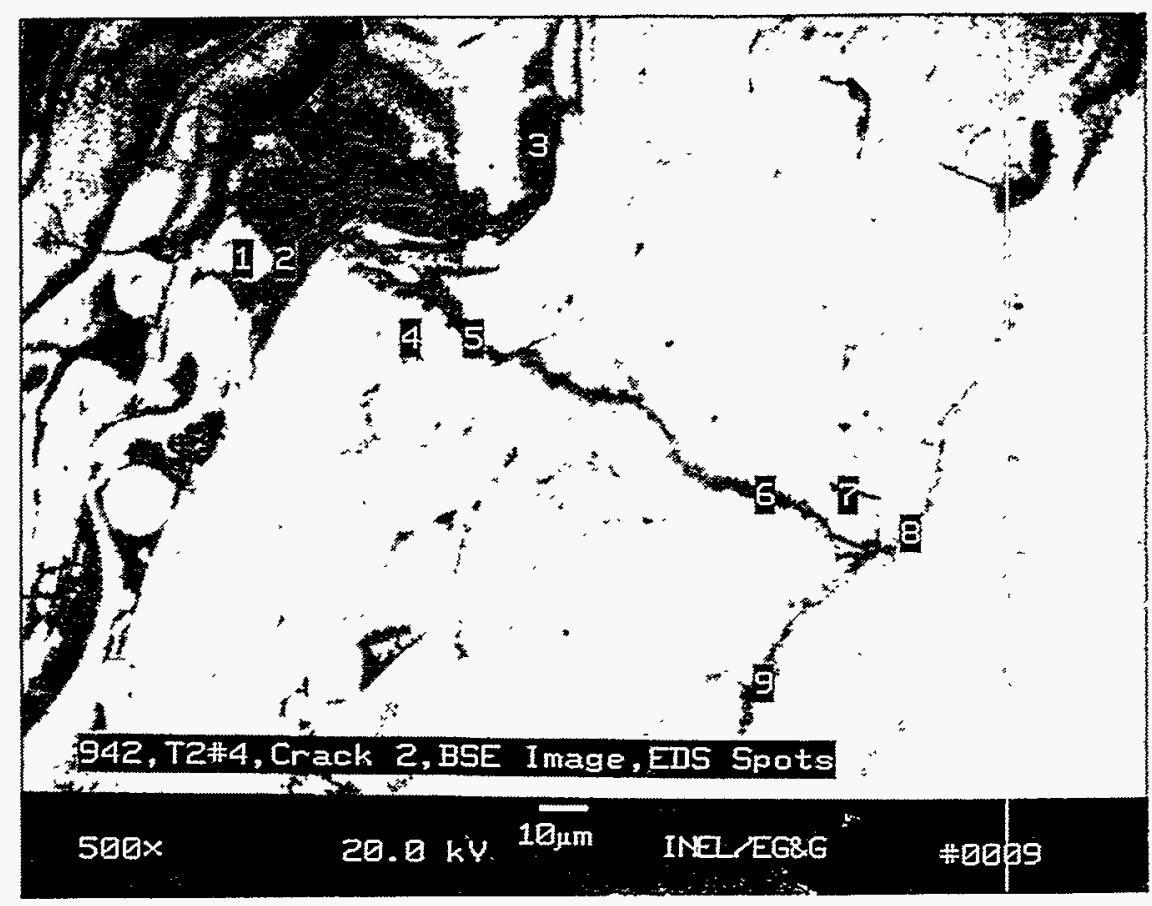

Figure 24. $500 \mathrm{x}$ view of 083-4. 
Table 10. Results of analysis of areas shown in Figure 24.

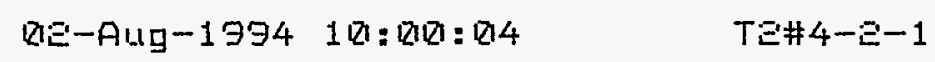

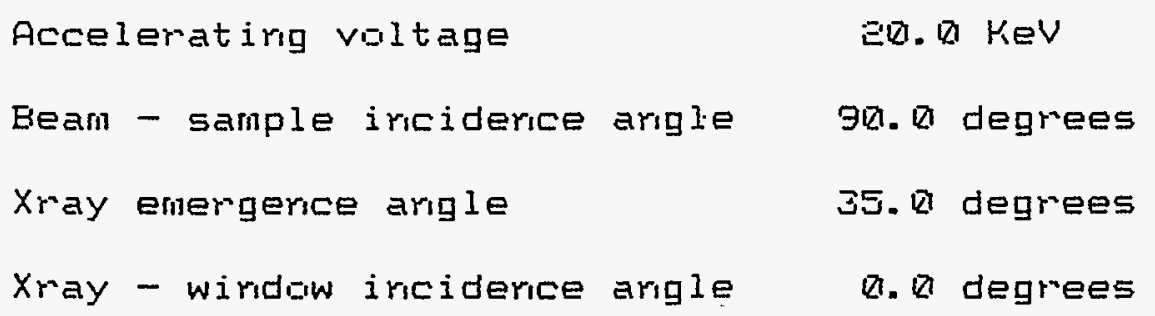

STANDARDLESS EDS ANALYSIS

( $Z A F$ CORRECTIONS VIA MAGIC $V$ )

\begin{tabular}{|c|c|c|c|c|}
\hline ELEMENT & WEIGHT & ATOMIC & PRECISIC & \\
\hline \& LINE & PERCENT & F'ERCENT* & $=$ SIGMA & $K-R A T I C$ \\
\hline$K A$ & 13.63 & 34.07 & 1. 1214 & ด. ฉ日eอ3 \\
\hline$A l K A$ & 5.19 & E. 74 & D. 14 & ฉ. ฉะ89 \\
\hline$T_{i} K A$ & 78.43 & 57.34 & 0.47 & $\square .7 \in Q 4$ \\
\hline$K A$ & E. 17 & 1.47 & $\square . \Xi \square$ & 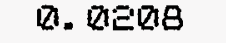 \\
\hline$F \equiv K A$ & 0.57 & 0.36 & ฉ. 018 & Q. \\
\hline
\end{tabular}

TOTAL $\quad 99.99$

ITERATIONS 8

*NOTE: ATOMIC FERCENT is rummalized ta 1 DIR

**NOTE: K-RATIO $=K-$ RATIO $\times R$

where $R=$ refererice (staridard)/refererice (sample)

NORMALIZATION FACTOR: 1. DURI 
Table 10. (continued).

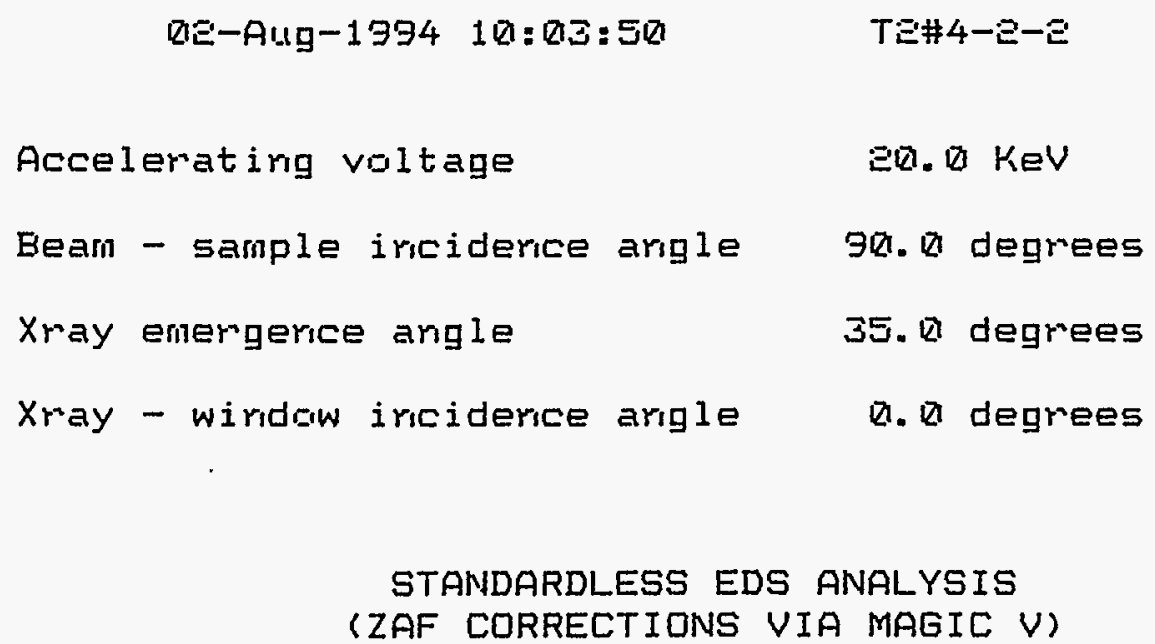
(ZAF CORRECTIONS VIA MAGIC V)

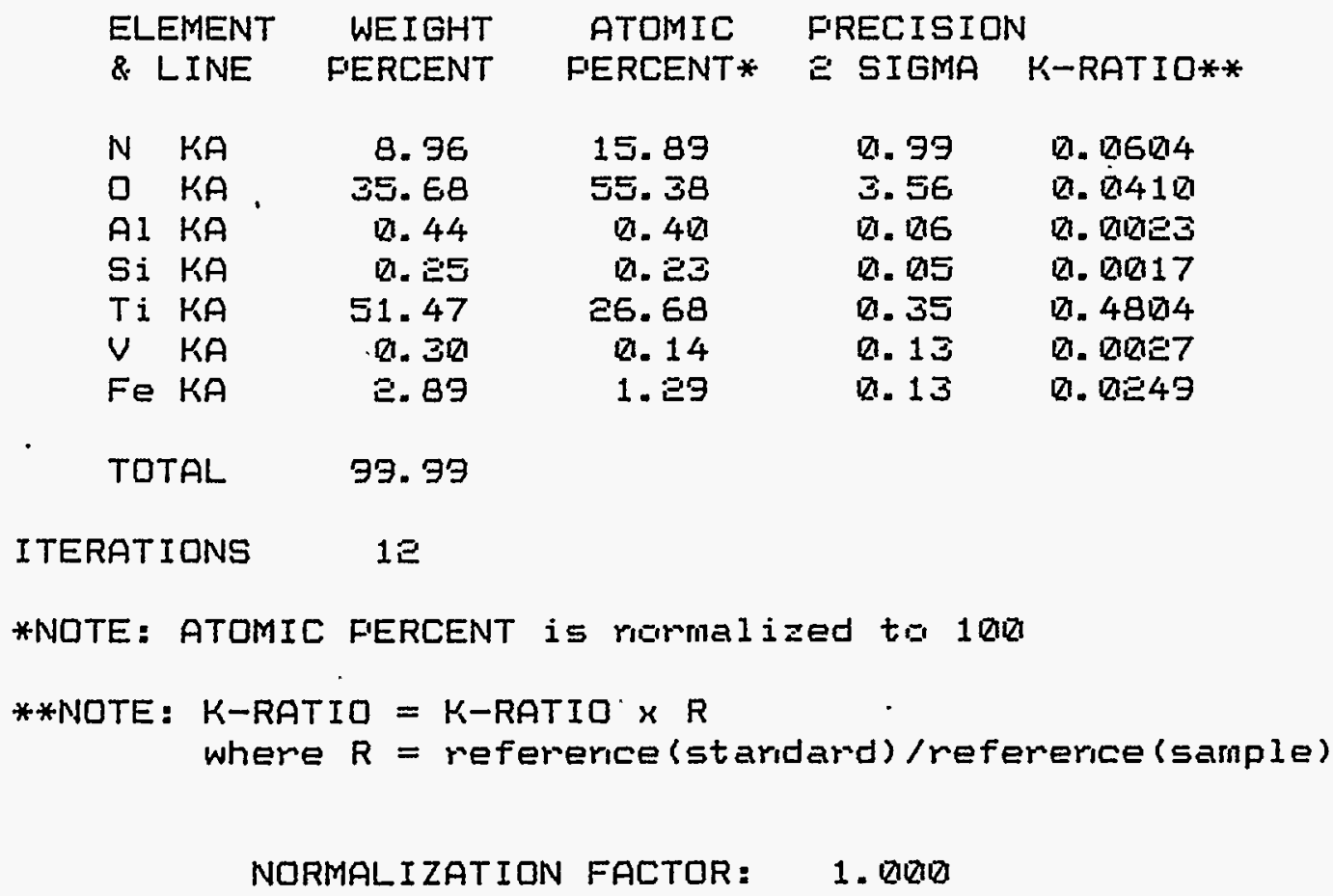


Table 10. (continued).

$$
\text { BE-Aแg-1994 1Q: Q88:14 }
$$

Tジサーシーーこ

$$
\begin{aligned}
& \text { Accelerating voltage 2Q. } 8 \mathrm{KeV} \\
& \text { Eeam - sample ircidence argle } 9 \square .0 \text { degrees } \\
& \text { Xray emergence arigle 35. D degrees } \\
& \text { Xray - wiridaw iriciderice argle Q. Degrees }
\end{aligned}
$$

STANDARDLESS EDS ANALYSIS

(ZAF CORRECTIONS VIA MAGIC $V$ )

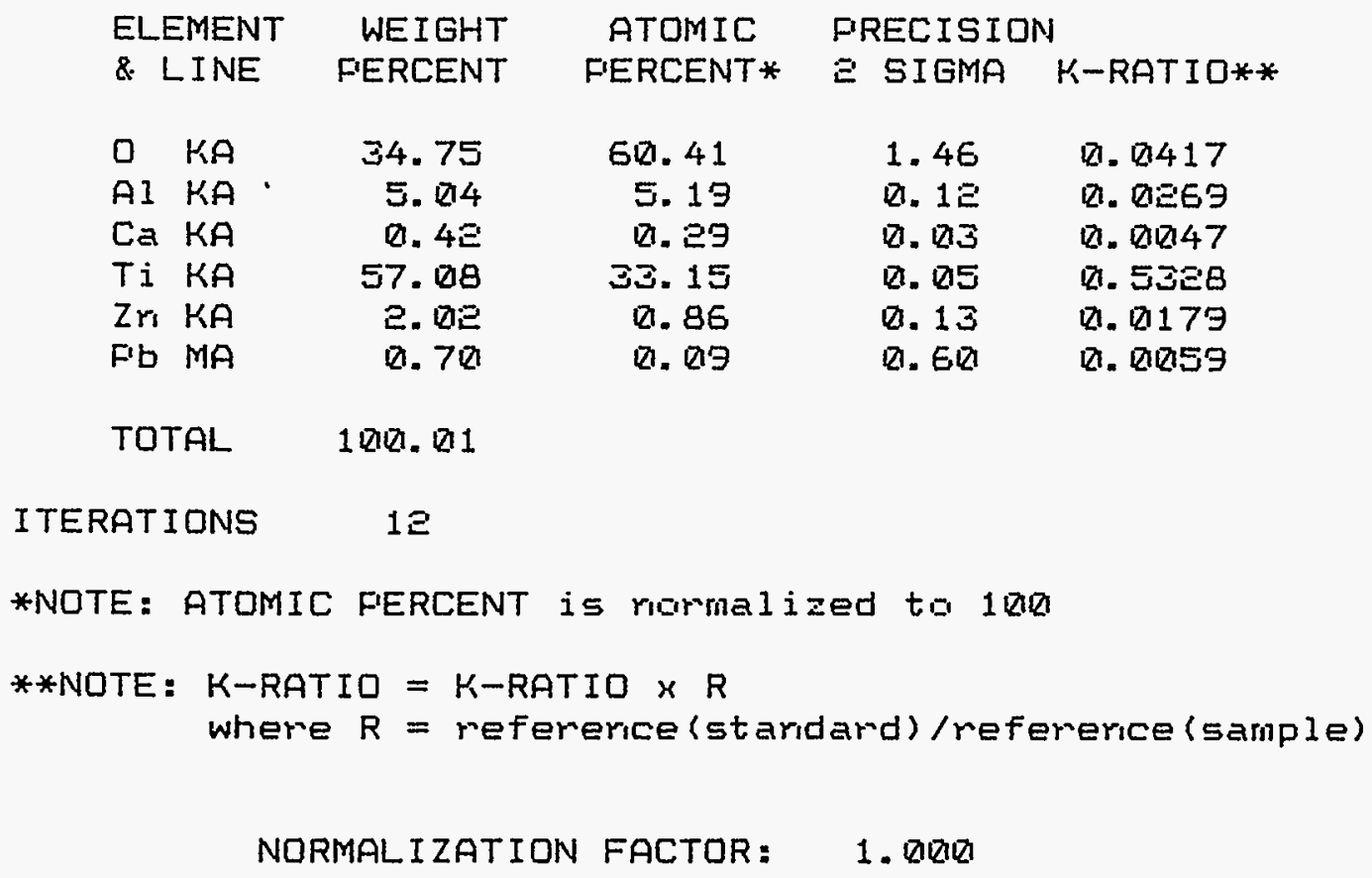


Table 10. (continued).

$$
\text { Q⿻一-Aug-1994 18:11:01 }
$$

Tอ\#4-อ-4

Accelerating voltage

20. $\mathrm{KeV}$

Beam - sample incidence angle

90. 87 degrees

Xray emergence angle

35.8 degrees

Xray - window inciderice arigle

Q. degrees

STANDARDLESS EDS ANALYSIS

(ZAF CORRECTIONS VIA MAGIC $V$ )

\begin{tabular}{|c|c|c|c|c|}
\hline \multirow{2}{*}{$\begin{array}{l}\text { ELEMENT } \\
\& \text { LINE }\end{array}$} & WEIGHT & ATOMIC & \multicolumn{2}{|c|}{ FRECISION } \\
\hline & F'ERCENT & F'ERCENT* & I SIGMA & K-RATID* \\
\hline$K A$ & 25.59 & 53.41 & Q1. 98 & Q. 1692 \\
\hline $1 \mathrm{KA}$ & E. 67 & 2. 89 & Q. 11 & ‥ 8149 \\
\hline $\mathrm{Ti} K A$ & $69.6=$ & $4 \Xi .49$ & 0.44 & 0.6655 \\
\hline$V \quad K A$ & E. 11 & 1. $: 1$ & Q. 19 & ฉ. 0199 \\
\hline
\end{tabular}

TOTAL $\quad 99.99$

I TERATIONS

$\exists$

*NOTE: ATOMIC FERCENT is nommalized to 100

**NOTE: K-RATIO $=$ K-RATIO $\times R$

where $R=$ reference (staridard) /reference (sample)

NORMALIZATION FACTOR: 1.080 
Table 10. (continued).

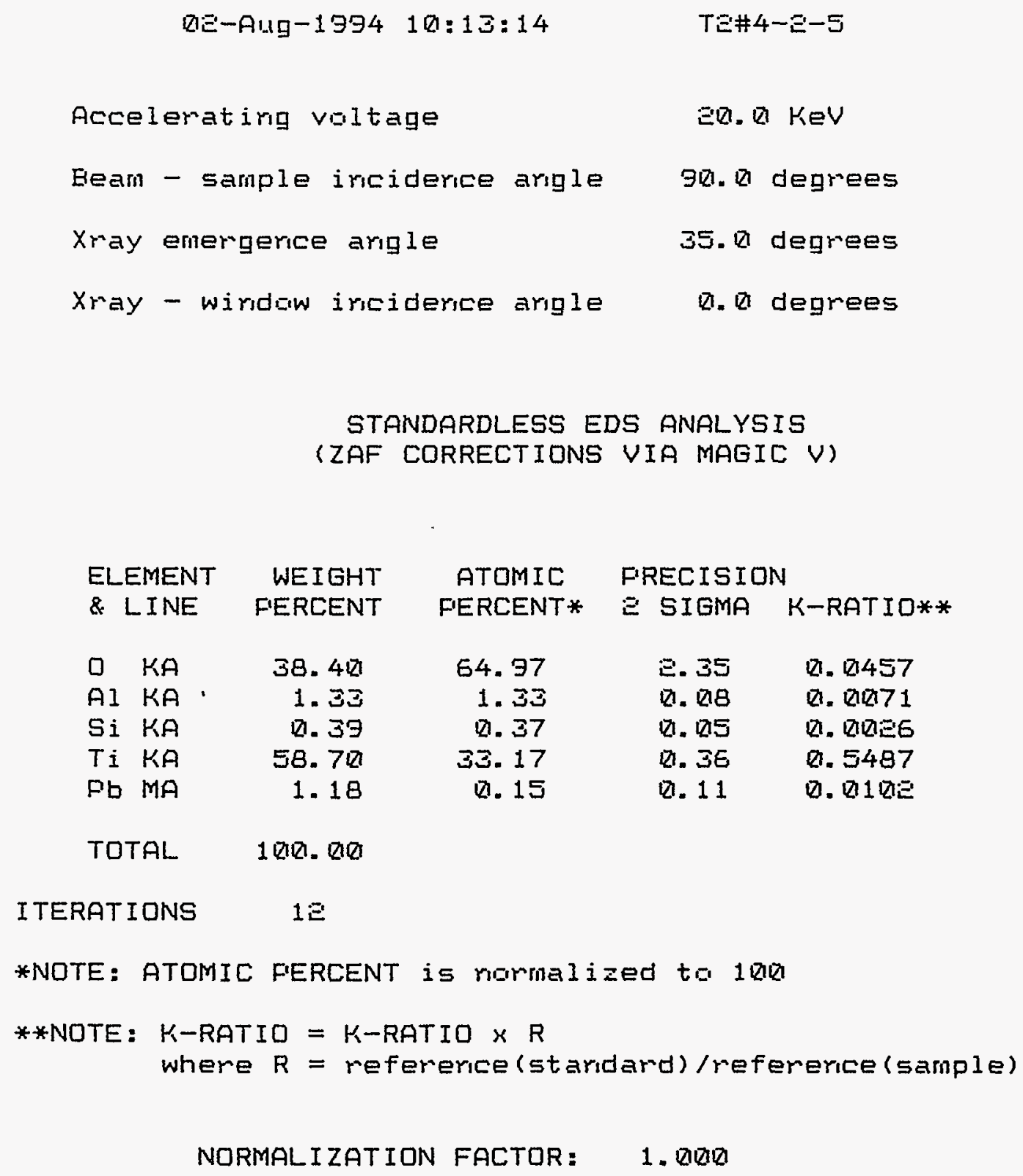


Table 10. (continued).

$$
\text { ถะー-Aแg-1994 18:18:26 }
$$

TЕ\#4-シーー6

Accelerating voltage

Beam - sample iriciderice argle

Xray emergence arigle

Xray - wirdow inciderice argle en. $\mathrm{KeV}$

9Q. 1 degrees

$35 . \emptyset$ degrees

Q. degrees

STANDARDLESS EDS ANALYSIS

(ZAF CORRECTIONS VIA MAGIC V)

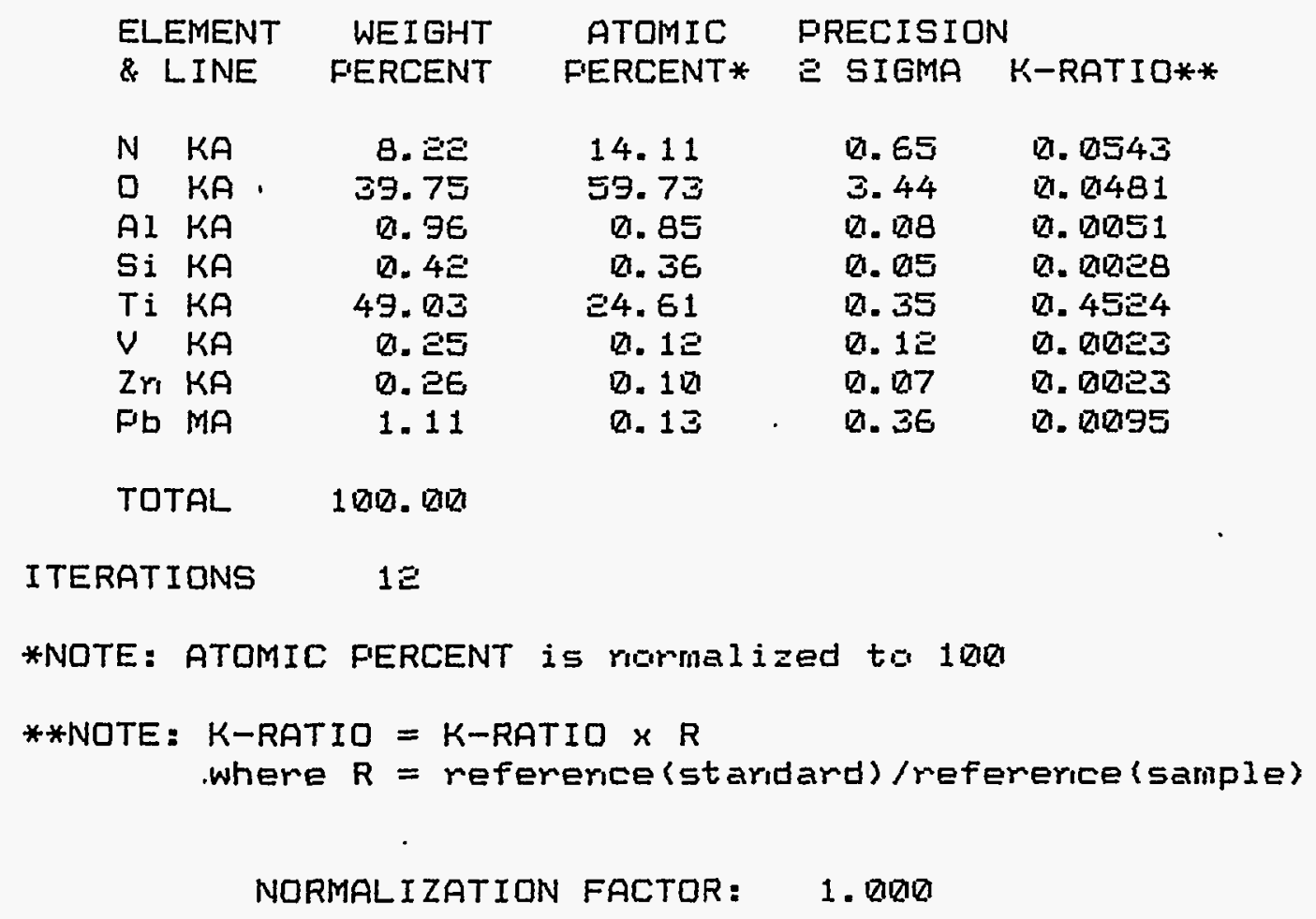


Table 10. (continued).

\begin{tabular}{|c|c|}
\hline Dت-Aug-1994 $10: \Xi 1: 17$ & $T \Xi \# 4-\Xi ー 7$ \\
\hline Accelerating valtage & $\Xi \square . \nabla \mathrm{KeV}$ \\
\hline Bearn - sample iriciderice arigle & 98.17 degrees \\
\hline Xray emergence arigle & 35.0 degrees \\
\hline - wiridow iriciderice arigle & Q1. Q $20 \mathrm{~d}$ \\
\hline
\end{tabular}

STANDARDLESS EDS ANALYSIS

(ZAF CORRECTIONS VIA MAGIC $V$ )

\begin{tabular}{|c|c|c|c|c|c|}
\hline \multicolumn{2}{|c|}{ ELEMENT } & WEIGHT & ATOMIC & \multicolumn{2}{|c|}{ FRECISION } \\
\hline & INE & FERCENT & F'ERCENT* & E SIGMA & $K-R A T I$ \\
\hline$N$ & $K A$ & 21.73 & 48. $: 1$ & ㅁ. 94 & Q7. 144 \\
\hline 0 & $K A$ & Q. DIRI & D. $D a n$ & 81.80 & Q1. 28002 \\
\hline A] & $\mathrm{KA}$ & E. 13 & $=.45$ & 0.10 & Q. $\nabla 118$ \\
\hline$T$ & $K A$ & 74.25 & 48.18 & Q1. 44 & D. 714 \\
\hline v & $K A$ & 1.89 & 1.16 & Q. 18 & 8.817 \\
\hline
\end{tabular}

TOTAL 1QRI. QIRI

ITERATIONS $\quad 8$

*NOTE: ATOMIC FERCENT is rummalized to 1 QR

**NOTE: K-RATIO $=K$-RATIO $\times R$

where $R=$ reference (staridard)/refererice (sample)

NORMALIZATION FACTOR: 1. QRZR 
Table 10. (continued).

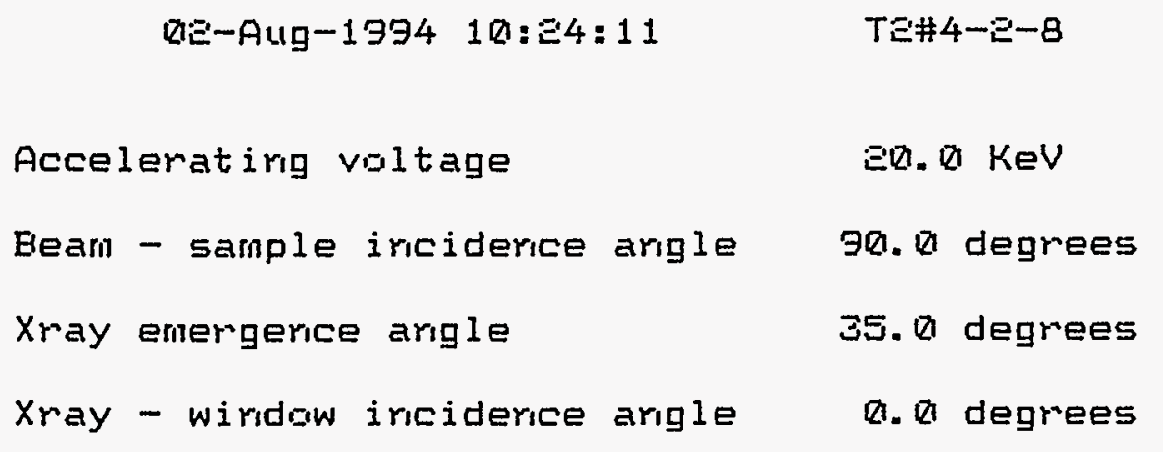

STANDARDLESS EDS ANALYSIS
(ZAF CORRECTIONS VIA MAGIC V)

\begin{tabular}{|c|c|c|c|c|}
\hline ELEMENT & WEIGHT & ATOMIC & F'REC ISID & \\
\hline \& LINE & PERCENT & F'ERCENT* & $\Xi$ SIGMA & K-RATIO** \\
\hline$K A$ & 4.90 & 9.23 & 1. $1 \Xi$ & ฉ. ఐЗコ \\
\hline$K A$ & 34.89 & 57.57 & 1.95 & ถ. 13886 \\
\hline AI KA & $0.9 \square$ & D. 88 & घ. 87 & D. 81048 \\
\hline Ti KA & $58.2 E$ & ЗЕ. ถЭ & 0.36 & D. 5448 \\
\hline$Z r_{1} \quad K A$ & Q. 3こ & ‥ 13 & 1.. 188 & 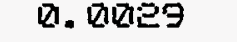 \\
\hline F'b $M A$ & D. 76 & 0.10 & Q1. 24 & Q. RQREE \\
\hline
\end{tabular}

TOTAL $\quad 99.99$

ITERATIONS $\quad 1 \Xi$

*NOTE: ATOMIC FERCENT is nammalized ta 1 QR

**NOTE: K-RATIO = K-RATIO $\times R$

where $R=$ reference (staridard)/refererice (sample)

NORMALIZATION FACTOR: 1. DUO 
Table 10. (continued).

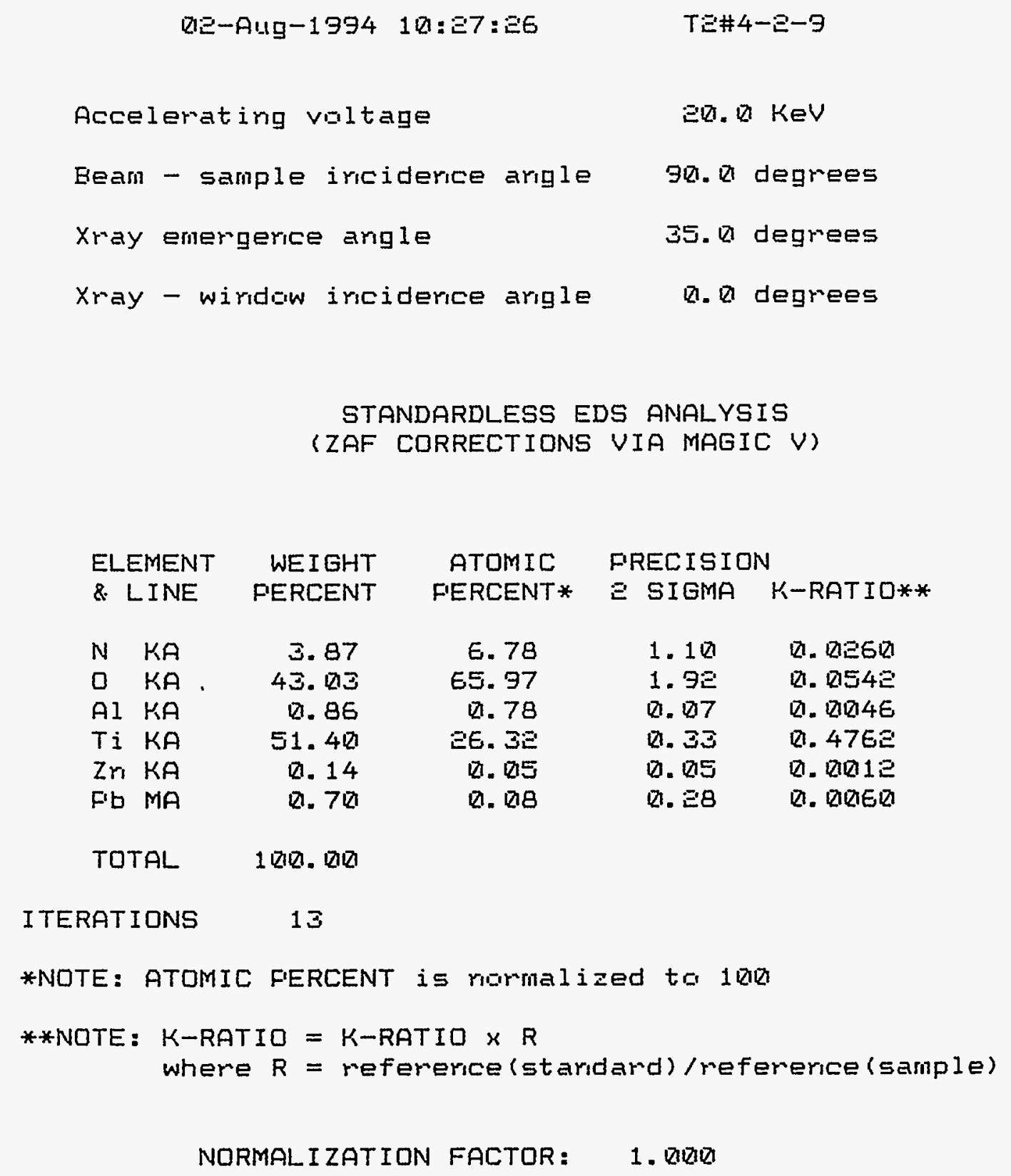




\section{EFFLUENT ANALYSIS}

The effluent analysis of the MODAR corrosion test reveals clues on the behavior of the metals, and chlorides in the system. The complete data analysis is in EDF ID 121217/1032 (Appendix B). The data from the last test run are shown here to make several observations. This test was the 120-hour test.

The feed consisted of the water/metal solution running at $80 \mathrm{cc} / \mathrm{min}$ and the TrimSol at $40 \mathrm{cc} / \mathrm{min}$.

The metal solution consisted of $5,400 \mathrm{ppm}$ of $\mathrm{CeCl}_{3}, 2,200 \mathrm{ppm}$ of $\mathrm{ZnCl}_{2}$, and 2,250 ppm of $\mathrm{PbCl}_{2}$.

The water/metals solution created a total volume of $80 \mathrm{cc} / \mathrm{min} \times(118 \mathrm{hr} \times 60 \mathrm{~min} / \mathrm{hr})=$ $566.4 \mathrm{~L}$.

The TrimSol solution created a total volume of $40 \mathrm{cc} / \mathrm{min} \times(118 \mathrm{hr} \times 60 \mathrm{~min} / \mathrm{hr})=$ $283.2 \mathrm{~L}$.

The chloride content of the feed stream is calculated below:

1. TrimSol $\left(30 \% \mathrm{C}_{20} \mathrm{H}_{37} \mathrm{Cl}_{5}\right)$

Carbon 12

Hydrogen 1

Chlorine 35.453

$\left(\mathrm{C}_{20} \mathrm{H}_{37} \mathrm{Cl}_{5}\right)=(12 \times 20)+37+(35.453 \times 5)=454.265$

Chloride $177.265 / 454.265=0.39$

$0.39 \times .3=11.77 \%$

$40 \mathrm{cc} / \mathrm{min} \times 118 \mathrm{hr} \times 60 \mathrm{~min} / \mathrm{hr}=283,200 \mathrm{~mL}$

$11.77 \%$ chloride $\times 283,200 \mathrm{~mL}=33,332.64 \mathrm{~g}$ of chlorides

2. $\mathrm{CeCl}_{3} 140.12+(35.453 \times 3)=246.479$

Chloride $106.36 / 246.48=0.43$

$0.43 \times 5,400 \mathrm{ppm}=2,330 \mathrm{ppm}$

$0.002330 \mathrm{~g} / \mathrm{mL} \times 566,400=1,319.7 \mathrm{~g}$ of chlorides

3. $\mathrm{PbCl}_{2} 207.19+(35.454 \times 2)=278.1$

Chloride 70.91/278.1 $=0.255$

$0.255 \times 2,250=573.69 \mathrm{ppm}$

$0.00057 \mathrm{~g} / \mathrm{mL} \times 566,400=322.85 \mathrm{~g}$ of chlorides

4. $\mathrm{ZnCl}_{2} 65.37+(35.454 \times 2)=136.278$

Chloride 70.91/136.278 $=0.52$

$0.52 \times 2200 \mathrm{ppm}=1144.73 \mathrm{ppm}$

$0.0011 \mathrm{~g} / \mathrm{mL} \times 566,400=623.04 \mathrm{~g}$ of chlorides 
Total Chlorides:

$33,332.64+1319.7+322.85+623.04=35,598.24 \mathrm{~g}$ of chlorides

It is important to note that the metal solution contributed $6.36 \%$ of the chloride loading. The metal chlorides are not considered high enough to be of significance.

The total volume of flow into the system was:

$\begin{array}{ll}\text { TrimSol } & 283,200 \mathrm{~mL} \\ \text { Water/metals } & 566,400 \mathrm{~mL} \\ \text { Purge Lines } & 1,628,400 \mathrm{~mL} \\ \text { Annulus } & \underline{2,124,000 \mathrm{~mL}} \\ \text { Total } & 4,602,000 \mathrm{~mL}\end{array}$

The amount of chlorides entering the system was $35,598.24 / 4,602,000 \mathrm{~mL}=0.0077 \mathrm{~g} / \mathrm{mL}=$ $7,735 \mathrm{ppm}$ of chlorides.

In Section 4 the stream was diluted at $350 \mathrm{cc} / \mathrm{min}$ or a total flow of $2,478,000 \mathrm{~mL}$. This lowered the concentration of chlorides to $35,598.24 / 7,119648=5,000 \mathrm{ppm}$ of chlorides.

The liquid effluent had a total flow of $1,250 \mathrm{cc} / \mathrm{min} \times 118 \mathrm{hr} \times 60 \mathrm{~min} / \mathrm{hr}=8,850 \mathrm{~L}$.

The lab analysis showed a chloride concentration of $1,800 \mathrm{ppm} ; 0.0018 \times 8,850,000=$ $15,930 \mathrm{~g}$ of chloride.

The chlorides collected from the various solid samples (see Table 11) was only $0.3792 \mathrm{~g}$ $15,930.4 / 35,598=0.4475$ or $44.75 \%$ mass balance was achieved on the chlorides from the effluent. This does not account for the amount of chlorides recovered from the posttest rinse or that remained settled in the feed tank as part of the surrogates.

Table 11. Solid effluent.

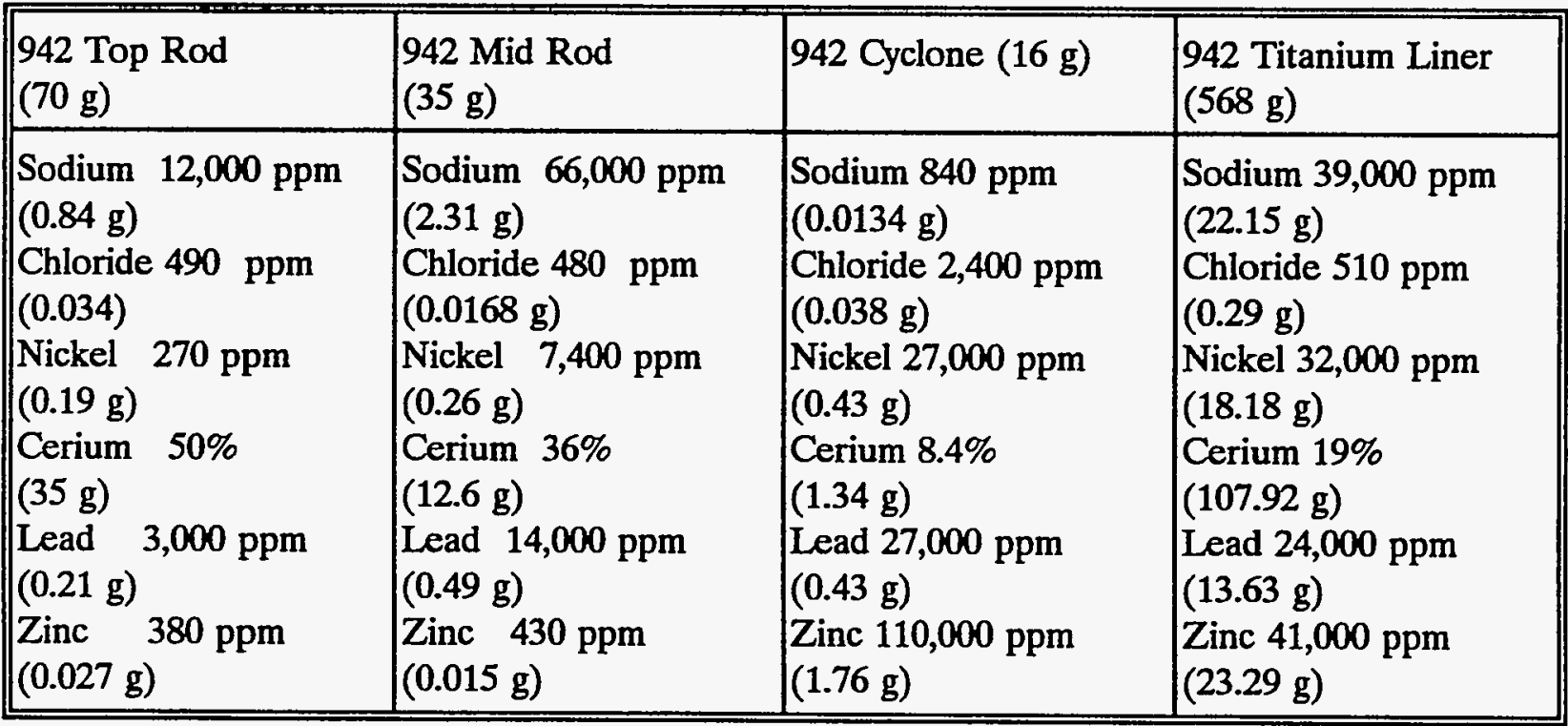


The solids were collected from several locations in the system. (See diagram in Appendix B.) The rod that held the metal coupons became a deposition surface within the casing.

The mass balance for the metals used the following calculations:

1. Cerium calculation

Cerium 140.12

Chloride 35.453

$\mathrm{CeCl}_{3} 140.12+(35.453 \times 3)=246.479$

Cerium $140.12 / 246.479=0.5679$

$0.5679 \times 5,400 \mathrm{ppm}=3,067 \mathrm{ppm}$ cerium $=(0.003 \times 566,400)=1,699.2 \mathrm{~g}$ of cerium

2. Zinc calculation

Zinc 65.37

Chlorine 35.454

$\mathrm{ZCl}_{2}(65.37)+(35.454 \times 2)=136.28$

$65.37 / 136.28=0.48$

$0.48 \times 2,850 \mathrm{ppm}=1367.1 \mathrm{ppm}$ of zinc $=(0.0014 \times 566,400)=774.32 \mathrm{~g}$ of zinc

3. Lead calculation

Lead 207.19

Chlorine 35.453

$\mathrm{PbCl}_{2} 207.19+(35.454 \times 2)=278.1$

$207.19 / 278.1=0.745$

$0.745 \times 2,250=1676.31 \mathrm{ppm}$ lead $=(00167 \times 566400)=945.89 \mathrm{~g}$ of lead

The metals mass balance takes into account the amount of surrogates that settled to the bottom of the tank, and the amount found in the posttest rinses. The feed contained approximately, 1,699 grams of cerium, 774 grams of zinc, and 946 grams of lead.

Lab analysis of the metal feeds indicates that only 4,500 ppm of cerium instead of 5,400 ppm, 1,230 ppm of lead instead of $2,250 \mathrm{ppm}$, and 1,840 ppm of zinc instead of 2,850 ppm actually went into the system as: feed with the remainder left behind at the bottom of the tank. This results in the total metals in the feed as $1,447 \mathrm{~g}$ of cerium instead of $1,699 \mathrm{~g}, 519 \mathrm{~g}$ of lead instead of $946 \mathrm{~g}$ and $500 \mathrm{~g}$ of zinc instead of $774 \mathrm{~g}$.

The solids effluent from Table 11 gives the following results:

- Cerium $156.86 \mathrm{~g}$

- $\quad 25.09 \mathrm{~g}$

- Lead $14.76 \mathrm{~g}$

The liquid effluent from Table 12 gives the following results: 
- Cerium ND

- Zinc $\quad 150.45 \mathrm{~g}$

- Lead $\quad 2.56 \mathrm{~g}$

The posttest rinses from Table 13 gives the following results:

- Cerium $450 \mathrm{~g}$

- Zinc $140 \mathrm{~g}$

- Lead $110 \mathrm{~g}$

The total cerium regained was $606.86 \mathrm{~g}$. This is $606.9 / 1447=42 \%$.

The total zinc regained was $315.54 \mathrm{~g}$. This is $315 / 500=63 \%$.

The total lead regained was $127.32 \mathrm{~g}$. This is $127 / 519=24.5 \%$.

The cerium deposits were seen primarily at the top of the rod, then the middle of the rod, and then the titanium liner, with a small amount found in the cyclone and none in the liquid effluent. It would appear that as soon as the surrogates mixed with the oxidant, the cerium begins depositing and probably coated most surfaces inside the casing. The recovery of cerium was $42 \%$ with most of that from the posttest rinses. It can be assumed that the remaining cerium is on the ceramic rings. This resistance to rinsing illustrates the importance of controlling deposition on walls versus relying on posttest rinsing to recover deposits. Further investigation is needed of the effect of cerium depositing on the ceramic rings. The SEM analysis shows the cerium showing up on the surface of the ceramic coatings but not being absorbed into the cracks of the coatings. The controlling mechanism for this behavior is not understood.

In the 120-hour run, $1447 \mathrm{~g}$ of cerium was fed into the system or approximately $12 \mathrm{~g} / \mathrm{hr}$. The amount of cerium that would be captured in the brine of an ongoing system run is not known. A buildup of an actual radionuclide such as plutonium could occur on the scale of several grams per hour. The amount of deposition at the top of the reactor could become an operating constraint.

Deposits of lead were found further downstream than cerium on the titanium liner and in the cyclone. The rinsing process recovered most of the lead while relatively little was found in the top or the middle rod deposits. A brine level in the reactor would most likely increase lead recovery.

The zinc had the highest recovery rate, appearing mostly in the cyclone and rinse processes. 
Table 12. Liquid effluent.

\begin{tabular}{||l|l||}
\hline Chloride & $1,800 \mathrm{ppm}$ \\
\hline Sulfate & $300 \mathrm{ppm}$ \\
\hline Cerium & $\mathrm{ND}$ \\
\hline Chromium & $3.2 \mathrm{ppm}$ \\
\hline Iron & $0.12 \mathrm{ppm}$ \\
\hline Lead & $0.29 \mathrm{ppm}$ \\
\hline Moly & $0.53 \mathrm{ppm}$ \\
\hline Nickel & $5.27 \mathrm{ppm}$ \\
\hline Potassium & $20 \mathrm{ppm}$ \\
\hline Sodium & $2,500 \mathrm{ppm}$ \\
\hline Zinc & $17 \mathrm{ppm}$ \\
\hline
\end{tabular}

Liquid Effluent:

$1,250 \mathrm{cc} / \mathrm{min} \times 118$ hours $\times 60 \mathrm{~min} / \mathrm{hr}=8,850$ liters

Table 13. Posttest rinses.

\begin{tabular}{||l|l|l|l||}
\hline $\begin{array}{l}\text { Vessel/Brine Take Off } \\
(17 \mathrm{~L})\end{array}$ & Rinse \#1 $(1,517 \mathrm{~g})$ & Rinse \#2 $(2,988 \mathrm{~g})$ & $\begin{array}{l}\text { Rinse Supernatant } \\
(215 \mathrm{~L})\end{array}$ \\
\hline $1 \mathrm{~g}$ of cerium & $334 \mathrm{~g}$ of cerium & $63 \mathrm{~g}$ of cerium & $52 \mathrm{~g}$ of cerium \\
\hline & $73 \mathrm{~g}$ of lead & $36 \mathrm{~g}$ of lead & $1 \mathrm{~g}$ of lead \\
\hline & $15 \mathrm{~g}$ of zinc & $78 \mathrm{~g}$ of zinc & $47 \mathrm{~g}$ of zinc \\
\hline
\end{tabular}




\section{DISCUSSION}

The nickel-based alloys (Hastelloy C-276 and Inconel 625) that have been used in other SCWO test systems do not show adequate corrosion performance in the SCWO environment where TrimSol and surrogates are present as feedstock that results in an oxidizing, chloride containing waste feed. Inconel 686 is the latest corrosion resistant alloy from International Nickel and is advertised as a replacement for Inconel 625 for use in highly oxidizing environments. The results show that Inconel 686 does not offer any improvement over Inconel 625 . Hastelloy C-22 is being marketed as a replacement for Hastelloy C-276 for applications such as oxidizing and reducing aqueous media. Hastelloy $\mathrm{C}-22$ was found to offer improved corrosion resistance over Hastelloy C-276 but the corrosion rates would not be acceptable for these conditions. The experimental nickel-based alloys (620 and 621) are based on the Hastelloy C-22 chemistry with increased chromium (25\%) with a varying molybdenum content. They have the best corrosion resistance of all the alloys tested but still have rates that will not work for an engineered structure.

Ceramic materials offer attractive corrosion resistant properties but are difficult to fabricate into certain forms. The plasma-sprayed ceramic coating testing was undertaken to see if an overlayed ceramic barrier would provide protection to a metallic substrate and improve its corrosion performance. The coating design was based on the aerospace thermal barrier coating. This coating has been thoroughly characterized for its thermal performance on jet engines due to the formation of fine microcracks throughout the coating.

The coating was applied using the thermal spray process in air. This results in a coating that is less dense than that of a coating sprayed in a vacuum. It will also entrap air during the coating process that will react with the atomized powders to form oxides.

The results from the visual examinations and the light and electron microscopy provide answers to the following question: Does the increased cost and complexity of the coated barrier system offer a measurable increase of corrosion resistance of the liner/reactor system as compared to the best uncoated system? The data indicate that multilayered ceramics can provide protection to substrates that would increase the life of the structural wall. The coating substrate systems did react differently to the combination of a high temperature, high pressure system with a corrosive feedstream.

The results indicate that thermal expansion properties of the coatings were sufficient to withstand the temperature cycles. A ring from each coating was thermally cycled before testing. These rings from the different coating systems were thermally cycled in air from room temperature to over $650^{\circ} \mathrm{C}$ in less than 5 minute cycles, up to 10 times with no coating cracking or delamination. The coatings did show cracks perpendicular to the surface but this is considered normal because these cracks relieve the thermal stresses during the thermal cyclings. The effect of these cracks on the overall corrosion performance of the ceramic coating system was then evaluated along with corrosion resistance of the coatings. Previous industrial experience has shown the coating systems that were most suited for thermal expansion were the zirconias applied over the nickel/chrome/aluminum bond layer. The results show that these rings suffered from the greatest amount of delamination. 
The perpendicular coating cracks will allow the test solution to enter into the coating. When the test was planned the requirements for the top layer of the coating were stated in terms of density. The permeability and density of the coating was thought to be the key to the corrosion resistance of any coating. But the density of the top coating affects the ability of the layer to contract or expand. All ceramic coating system will have perpendicular cracks through the coatings. These cracks open at room temperature and close at higher temperature due to thermal expansion. The cracks would have a different size under the higher temperatures of the test but would not necessarily be completely closed. The cracks are seen in the EDT micrographs. It would appear that the coating delamination observed after the corrosion test was caused by these cracks in the ceramic coatings, allowing the test solution to penetrate through the coating and react with the various layers and the base metal substrate. The nickel/chrome/aluminum layers and the Inconel 625 base metal were the most susceptible to attack.

As the corrosion products formed within the ceramic layers, the volume increase caused an interlayer separation to open and propagate between the ceramic layers, leading ultimately to delamination.

The most important failure mechanism is the reaction of the coating or base metal with the test solution. Based on observation of the data, the mechanisms of thermal expansion or shock are secondary to the generation of corrosion products as the design constraint. The observations used for this conclusion were the behavior of the zirconia coatings. Coating A showed complete delamination in Section 5 and only blistering in Section 1 after 60 hours and five thermal cycles. If thermal expansion was the controlling mechanism, the delamination would have been expected in the ring that was in the higher temperature section.

EDF micrographic analysis showed corrosion products down to the bond coat. The difference between Coatings $\mathrm{A}$ and $\mathrm{B}$ was the addition of the alumina interlayer. Delamination occurred in Coating B both Section 1 and Section 5 after 60 hours. Figure 18 shows the delamination between the bond coat and the alumina interlayer. Corrosion products were found on the bond coat. There is no crack in the sample to analyze so it is not clear whether the corrosion products could have deposited after the delamination occurred. What can be seen is that some of the bond coat remained with the alumina after the delamination. This is more in keeping with the concept of a volume increase, causing a fissure between the layers. If the coatings had delaminated from thermal expansion all of the bond coat should have remained intact.

In the samples that had an Inconel 625 base substrate or a nickel/chrome/aluminum layer, the metal was attacked with the corresponding generation of corrosion products. This is not surprising based on the poor performance of the bare Inconel 625 samples in this test. An example of this is shown in the comparison of Ring 060-5 (Coating $C$ on Inconel 625) with Ring 083-5 (Coating F on Gr-12 titanium); Ring 060-5 failed while Ring 083-5 did well in the same location. Of the eight rings that had Coating $\mathrm{C}$, only one ring had sufficient coating integrity after 120 hours. This was Ring 049-13 that was located in the least corrosive zone. Of the five rings that had Coating $F$ on a titanium ring, all five of them had an intact top coat after 120 hours. It is felt that the good performance of the $\mathrm{F}$ coating was due to the fact that it contains no nickel/ chrome/aluminum layer or Inconel 625 base substrate. In the titania/titanium systems 
the corrosive species are still present within the cracks but do not attack the titanium. The titania sections have been analyzed for the existence of pitting at the bottom of any cracks but none have been found. See the following diagrams for the ceramic rings (Figures 25-29). This has great significance for the protection of titanium substrates. It is not known how much longer the titania coating will protect the titanium but these data indicate there is a potential for greatly increasing the life of the structure.

Whatever reactor is used to treat mixed waste will become radioactive. Any steps that lengthen the time between changing out components will improve the operating costs of the plant and the volume of waste produced.

It appears that the titania/alumina/vanadium coating system is not as susceptible to corrosion degradation as the nickel/chrome/aluminum coating system. For this reason the titania/titanium coating system is considered superior to the nickel-based system for the SCWO environment. Salt deposition on the any of the ceramics appears not to damage the ceramic, but this needs to be further investigated. The salt may increase the stress on the coating surface that may be removing thin layers of the coating. On some of the zirconia microsections, the salt appeared to be pulling away thin top layers of zirconia. This microspalling may be a mechanism that could degrade the titania. This coating should be subjected to the test environment for longer periods of time to assess any time dependent corrosion degradation. 


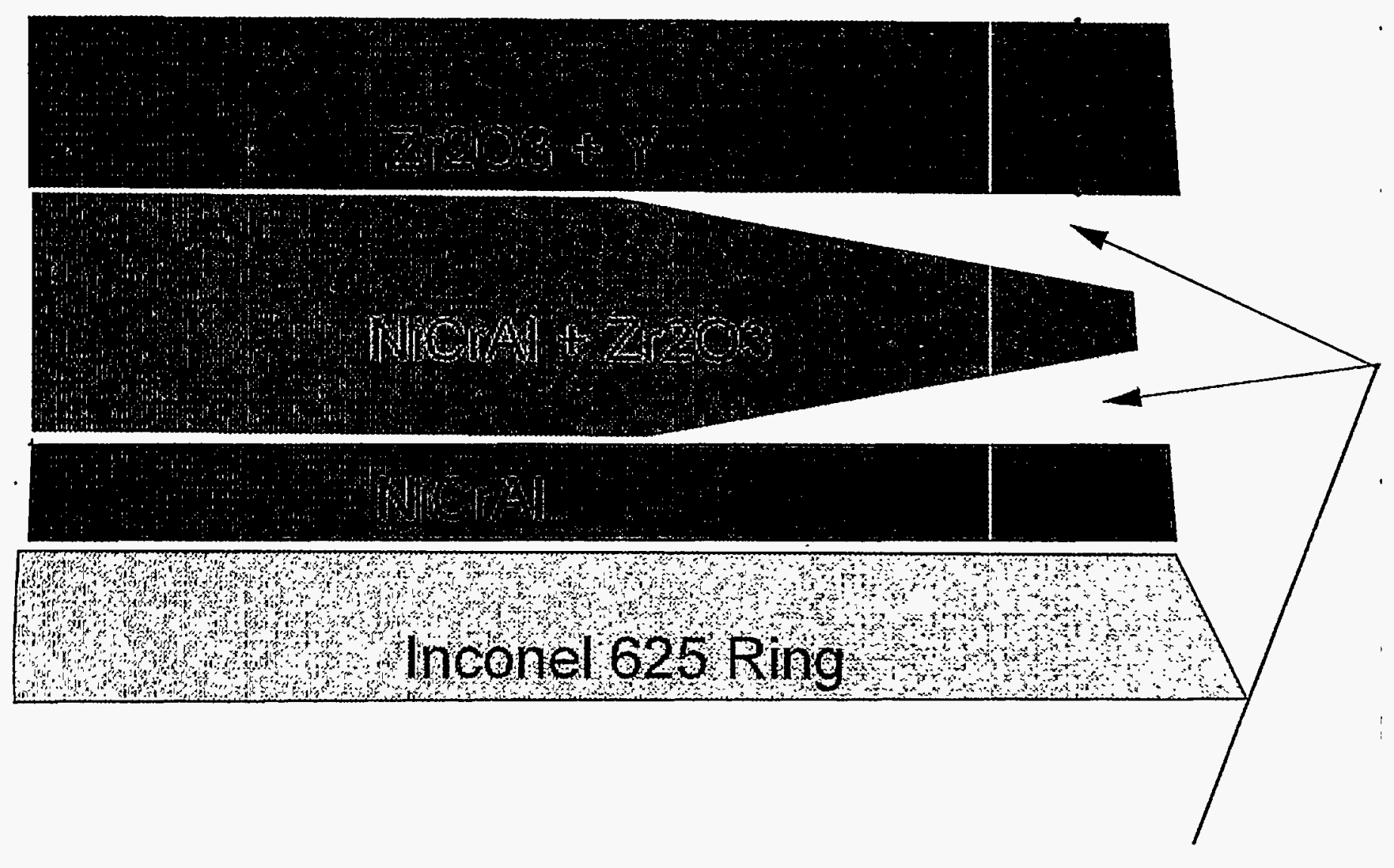

\section{7-5 Type A Coating}

Areas of Failure

Figure 25. Mechanisms of failure for Ring 047-5, Coating A. 


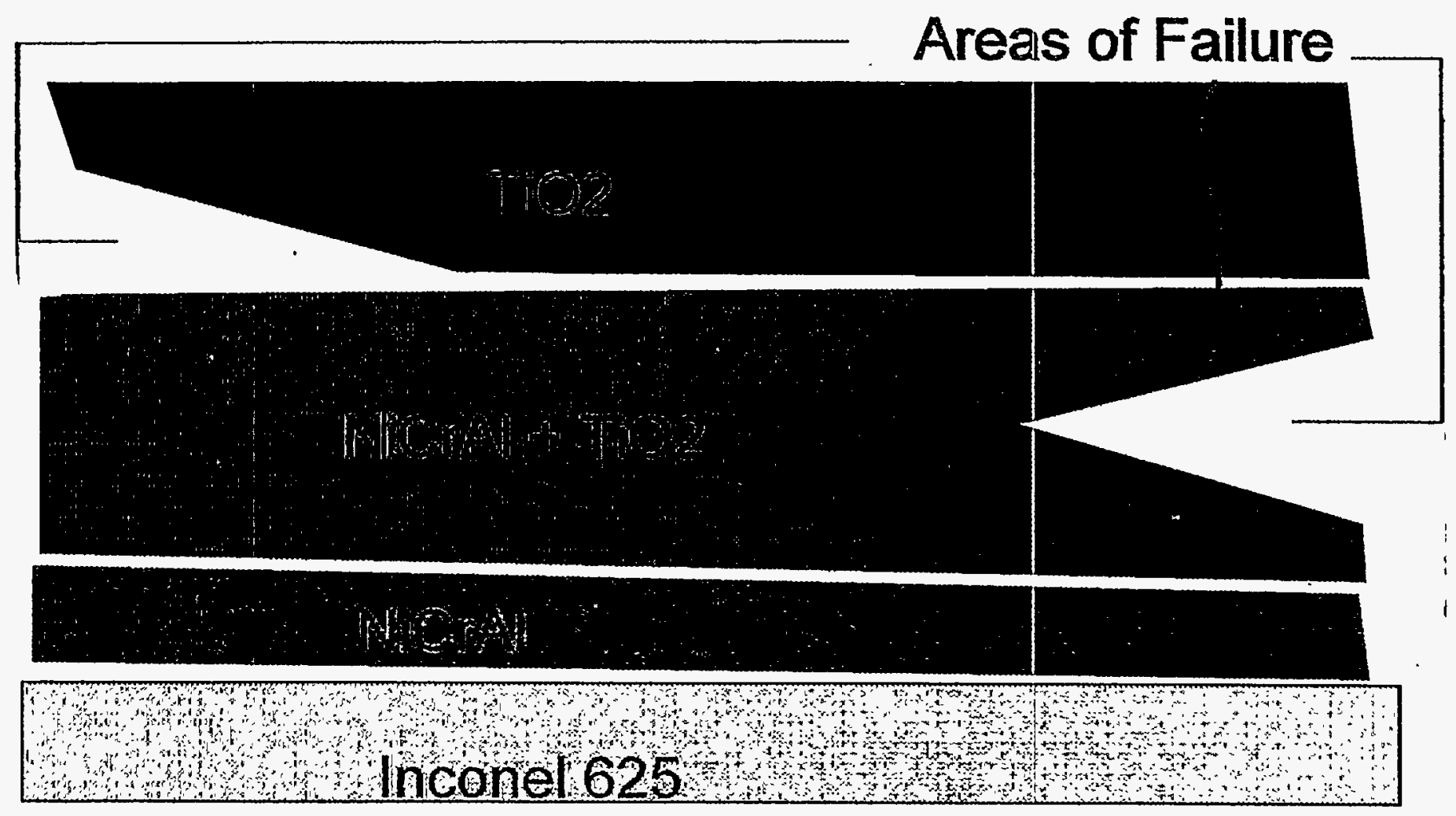

\section{9-16 Type C Ring}

Figure 26. Mechanisms of failure for Ring 073-7, Coating C. 


\section{Areas of Failure}
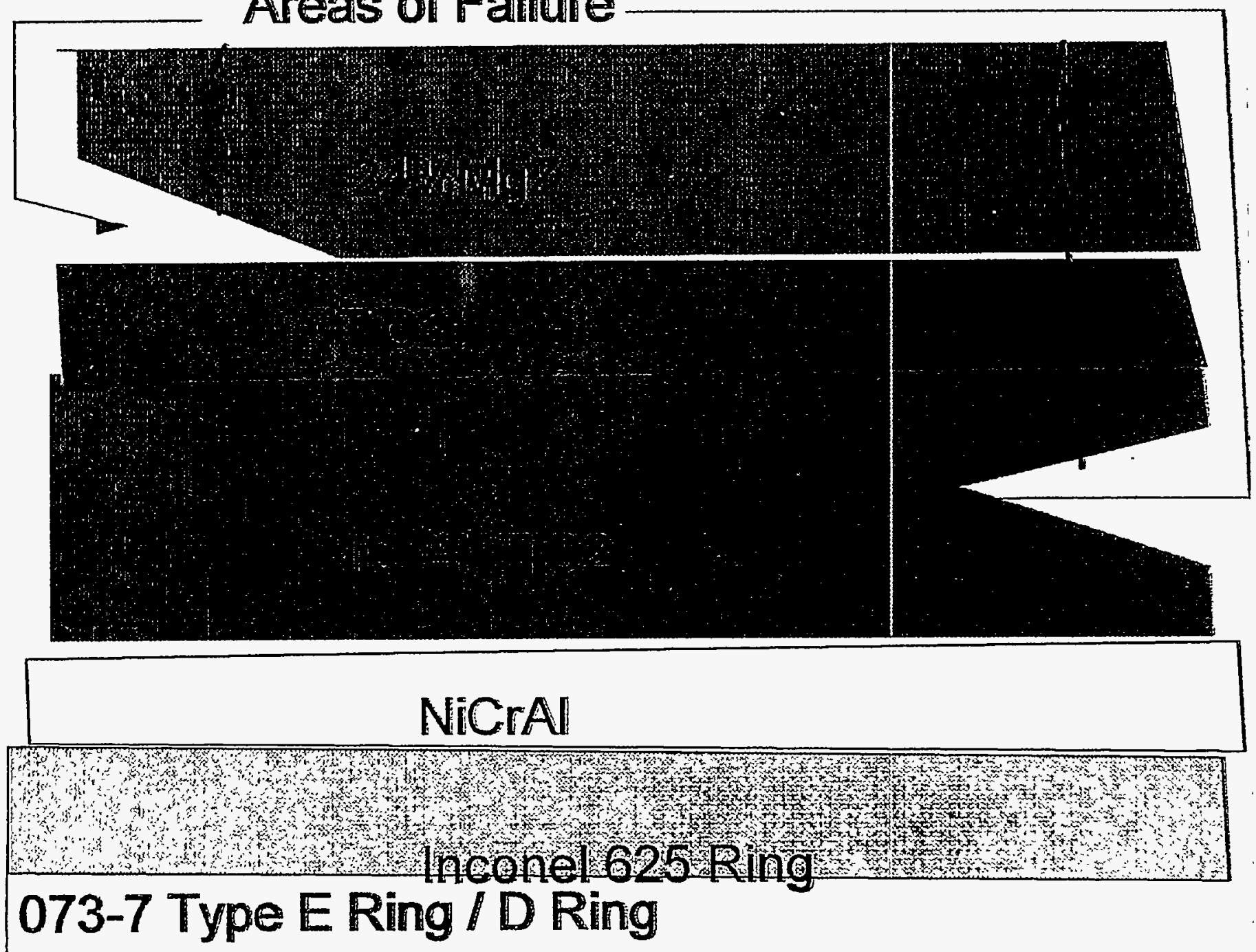

Figure 27. Mechanism of failure for Ring 073-7, Coating $\mathrm{E}$. 


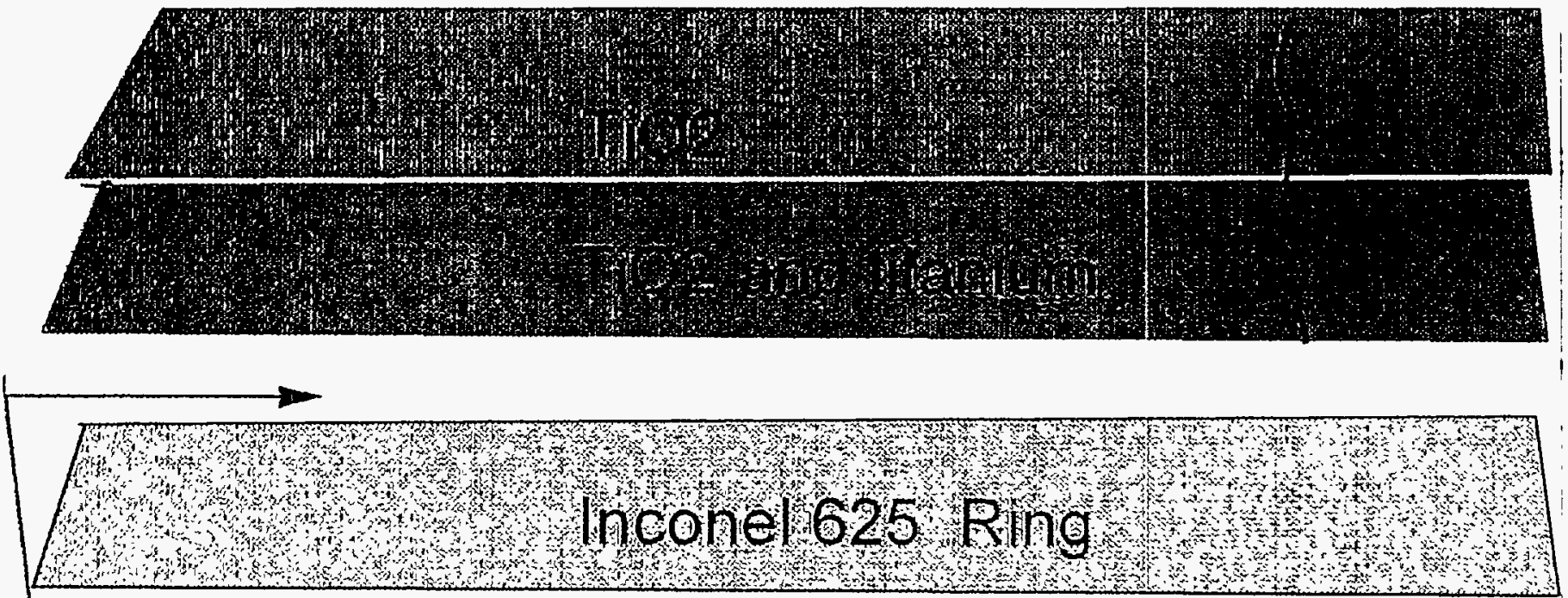

\section{Area of Failure}

\section{3-8 Type F coating with Inconel Ring}

Figure 28. Mechanism of failure for Ring 083-8, Coating F, with Inconel ring. 


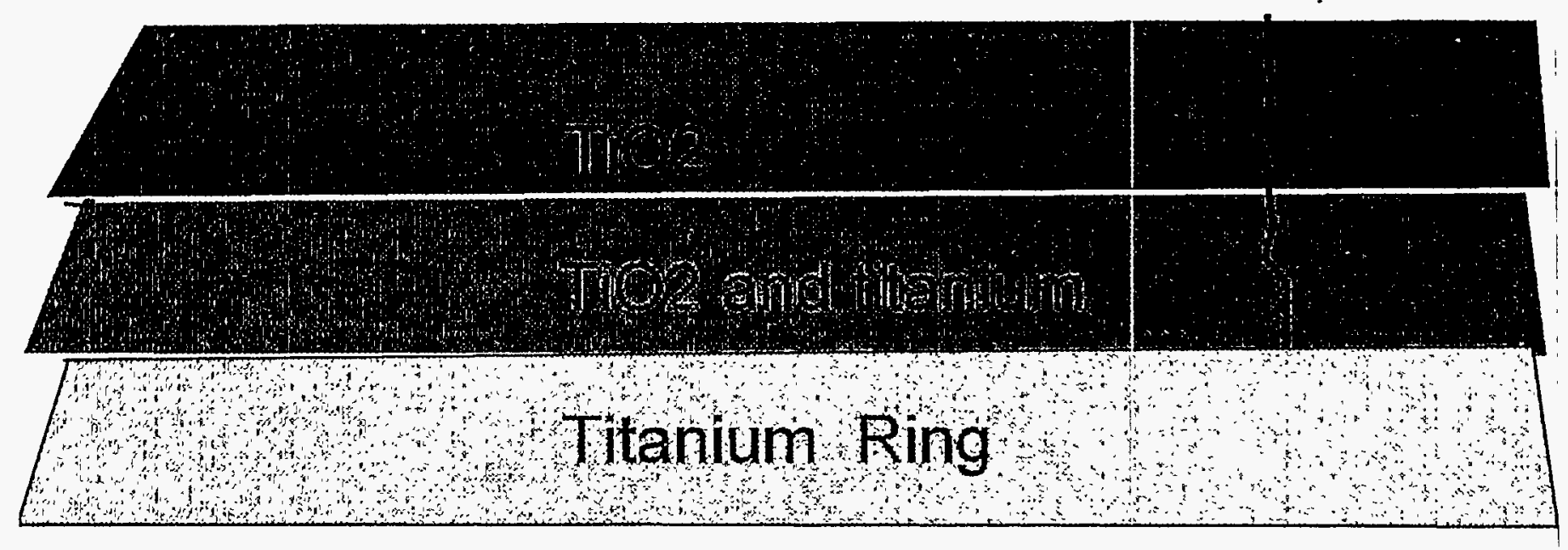

\section{3-4 Type F coating with Titanium Ring}

Figure 29. Mechanism of failure for Ring 083-4, Coating F, with titanium ring. 


\section{CONCLUSIONS}

This corrosion test was useful in increasing our understanding of how multilayered ceramics and nickel-based alloys would behave in an SCWO environment. The SCWO environment provides the opportunity for the interaction between the acids, salts, metals, oxygen, and the surface. The mechanisms are not thoroughly understood, only the end net effect can be seen in visual examination, weight loss analysis, and the microscopy. The goal of this testing was to find a system that would increase the life of the structural wall. The following statements can be made from these data:

- The nickel-based alloys (Inconel 625, Hastelloy C-276) commonly used in SCWO environments are severely degraded in the TrimSol containing waste stream.

- The Inconel 686 alloy recommended as a replacement for Inconel 625 in severe corrosion service does not offer any improvement in corrosion resistance in the TrimSol containing waste stream.

- Hastelloy C-22 shows improved corrosion resistance compared to Hastelloy C-276 but the rates would still be too high to be used.

- The experimental nickel showed improved performance over the baseline alloys but still has excessively high rates of corrosion.

- The corrosion rates of the nickel-based alloys decrease with increasing chromium content.

- The coupons in Section 5, the transition zone of the process, were not exposed to the acid environment and, therefore, do not provide any relevant information.

- The plasma-sprayed ceramic coatings show promise as a corrosion control measure.

- The test solution had access to the various coating layers and the metal substrate.

- The nickel-based coating layers and base metal were not resistant to the test solution that caused coating failures.

- The yttria-stabilized zirconia coatings reacted with the coatings forming reaction products that adversely affect coating life.

- None of the multilayered coatings were able to protect the alloy 625 substrate.

- Thermal cycling did not appear to have a dominant effect on the ceramic coatings. The rings withstood the thermal cycling test with no coating delamination.

- The all titania/titanium coating/base metal system was resistant to the test solution. With the initial data produced in this test, the coating system protected the titanium 
from the corrosive environment. The titania had very little reaction products within the coating.

- The titania/titanium coating/base metal system will increase the time between the changeout of the reactor. This is important because when treating mixed waste the reactor itself becomes a form of low-level radioactive waste when it is removed from the system.

- There are many parameters that need to be further studied. For example, it is not known if there is a wearing away of the titania on the surface of the coating or if the titania is spalling off locally. The impact of salt and oxide deposition onto the ceramic needs to be understood.

- The radiological and Resource Conservation and Recovery Act (RCRA) implications from the surrogates such as cerium found in the products deposited on the surfaces need to be studied. 


\section{RECOMMENDATIONS}

This corrosion test represents a preliminary effort to identify the direction of material investigations for the SCWO environment.

- Further corrosion testing with the TrimSol solution should be performed to test optimized parameters of coating titania onto titanium metal.

- The program should be repeated with the best performing coatings applied by the vacuum spray process to see if this coating application method is significant. This method should have a higher density with no internal oxides.

- The use of postspray surface thermal treatments (electron beam or laser) should be investigated. These treatments would reduce the residual thermal stresses in the coating.

- Other materials need to be investigated as coating systems such as noble metals.

- $\quad$ Other waste streams (Department of Defense, Department of Energy, and commercial) should be identified for testing with the coated and bare metal samples. Many of these waste streams will not be as aggressive as TrimSol.

- The test results of the nickel alloys indicate that increasing the chromium level decreases the corrosion rate in these solutions. It would be of interest to see if this trend continues as chromium levels increase up to $30 \%$.

- Further investigations are needed into other methods of applying the coating besides the thermal spray method, such as vapor deposition.

- Testing should be extended to welded metal coupons with ceramic coatings.

- It is not known if there is a wearing or wastage of the titania on the surface of the coating or if the titania is spalling off locally. Also, the impact of the salt and oxide deposition onto the ceramic needs to be understood.

- The radiological and RCRA implications of radionuclide deposition must be studied. The location and amount of the surrogate depositions is important to future system design. 
Appendix A

Bibliography

A-1 



\title{
BIBLIOGRAPHY OF SUPERCRITICAL WATER OXIDATION AND RELATED TECHNOLOGY LITERATURE
}

\author{
REVISION 10 August 1, 1994
}

References are listed under the following catagories:

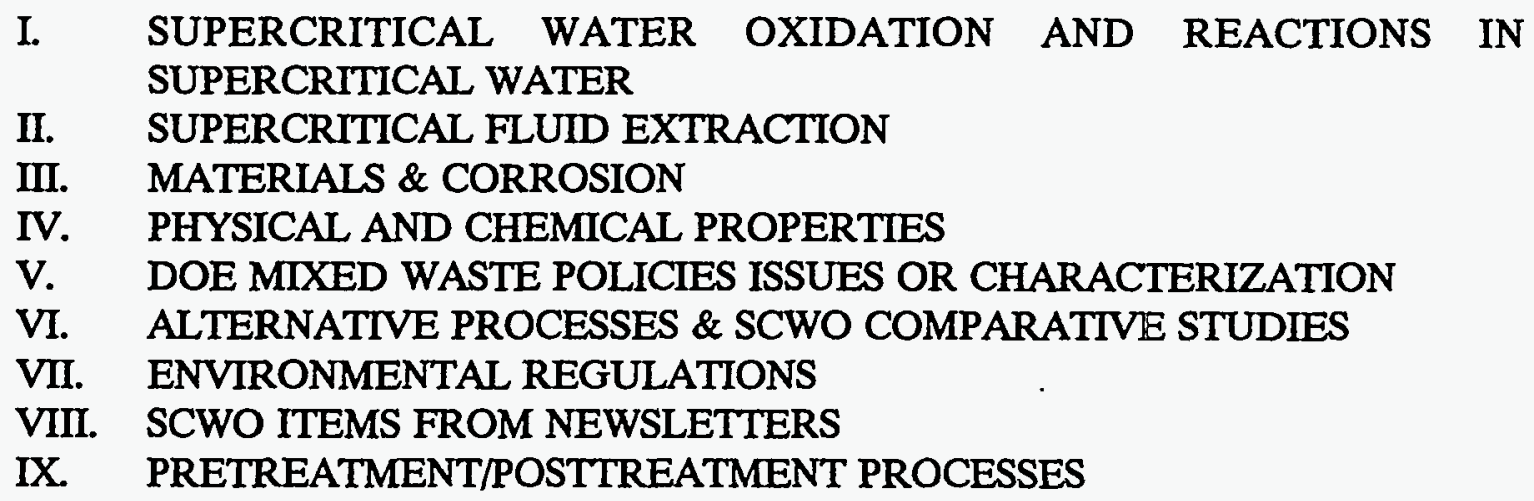

Literature is filed in the offices of Ralph Marshall, EROB W2 Room 213, 526-0841 or Charles Barnes, EROB E1 M1, 6-0864. Numbers below refer to the order in which literature is filed. Numbers preceded by " $\mathrm{A}$ " refer to abstracts and numbers preceded by " $\mathrm{N}^{n}$ to newsletter items.

\section{SUPERCRITICAL WATER OXIDATION AND REACTIONS IN SUPERCRITICAL WATER}

45. Proceedings, Workshop on Federal Programs Involving Supercritical Water Oxidation, July 6-7, 1992, NIST, Gaithersburg, MD, G. J. Rosasco, editor (Individual presentations from these proceedings are listed in this bibliography under " $45 \mathrm{a}^{\text {" to }}$ " $45 \mathrm{n}^{\mathrm{n}}$.)

138. Collection of SCWO information and papers received form Eco Waste Technologies (includes references 25, 75, 102, 134 plus additional information about Eco Waste and UTBRC SCWO research equipments and work)

145. Conference Proceedings, Fourteenth Annual U.S. Department of Energy Low-Level Radioactive Waste Management Conference, Phoenix, Arizona, Nov. 18-20, 1992. (Individual papers are listed under "145a" to "145d".)

41. M. B. Adrian, A Partial Literature Survey on Supercritical Water Oxidation, University of Texas at Austin report, May, 1991.

38. F. J. Armellini, J. W. Tester, "Salt Separation During SCWO of Human Metabolic Waste: Fundamental Studies of Salt Nucleation and Growth," SAE 20th Intersociety Conference on Environmental Systems, Williamsburg, Virginia, July 9-12, 1990.

149. F. J. Armellini, J. W. Tester, "Experimental Methods for Studying Salt Nucleation and Growth from Supercritical Water," J. Supercritical Fluids, 1991, 4, pp. 254-264. 
2. H. E. Barner, C. Y. Huang, T. Johnson, G. Jacobs, M. A. Martch, W. R. Killilea, "Supercritical Water Oxidation: An Emerging Technology," J. of Hazardous Materials 31, (1992) pp. 1-17.

2a. H. E. Barner, C. Y. Huang, T. Johnson, G. Jacobs, M. A. Martch, W. R. Killilea, "Supercritical Water Oxidation: An Emerging Technology," Presesented at ACHEMA'91 - Int. Meeting on Chemical Engineering and Biotechnology, June 9, 1991

211. C. M. Barnes, "Estimate of Capacity of SCWO Unit to Treat DOE Mixed Waste," EG\&G Interoffice Correspondence CMB-10-90, August 3, 1993.

244. C. M. Barnes, "Calculation of Relative Reactor Volumes and Oxygen Requirements for the Supercritical Water Oxidation Test Bed for Various Cases," EG\&G Engineering Design File, Project WTD-3YH061-074-HW, No. ID121217/13.

248. C. M. Barnes, "Information From the Advanced Oxidation Technologies Conference," EG\&G Interoffice Correspondence CMB-08-94, July 1, 1994.

250. C. M. Barnes, "Chemical Reactor Design for Supercritical Water Oxidation of U.S. DOE Waste," EG\&G Engineering Design File, Project WTD-3YH061-074-HW, No. ID121217/1026.

237. C. M. Barnes, Evaluation of Pretreatment Processes for Supercritical Water Oxidation, EGGWTD-11137, January 1994.

238. C. M. Barnes, Supercritical Water Oxidation Test Bed Effluent Treatment Study, EGG-WTD11271, April, 1994.

231. C. Barnes, K. Garcia, R. Mizia, C. Shapiro, J. Svoboda, G. Thurston, Supercritical Water Oxidation Test Bed Functional and Operation Requirements, EGG-WTD-11200, February 1994.

137. C. M. Barnes, R. W. Marshall, Jr., and K. M. Garcia to J. M. Beller, "Modar Facility Visit Trip Report," EG\&G Interoffice Correspondence, CMB-02-93, February 17, 1993.

200. C. M. Barnes, R. W. Marshall, Jr., Identification of Technical Constraints for Treatment of DOE Mixed Waste by Supercritical Water Oxidation, EGG-WTD-10768, October, 1993.

208. C. M. Barnes, N. R. Soelberg, Feasibility of Treating DOE Mixed Waste Using Supercritical Water Oxidation, Unpublished EG\&G Report, Draft, December 15, 1993.

233. J. M. Beller, Transmittal of Supercritical Water Oxidation Program Midyear Review Slides, March 7, 1994 [presentations by C. Oh, SCWO Computational Fluid Dynamics Modelling; P. B. Butler, SCWO Modeling; C. Shapiro, DOE/Navy Waste Testing Modar Pilot Plant; K. Garcia, Corrosion Testing; K Garcia, Ultrasonic Remote Measurement; C. M. Barnes, Salt Separation; C. Liu, Electrochemical Sensor Development] also attached are review comments resolutions. 
254. J. A. Bettinger, E. D. Ferland, W. Killilea, "Demonstration of the Modar Supercritical Water Oxidation Process," Presented at Waste Management Meeting, Tucson, Arizona, February 28March 4, 1994.

4. T. T. Bramlette, B. E. Mills, K. R. Hencken, M. E. Brynildson, S. C. Johnson, J. M. Hruby, H. C. Feemster, B. C. Odegard, M. Modell, Destruction of DOE/DP Surrogate Wastes with Supercritical Water Oxidation Technology, SAND90-8229, November, 1990.

64. S. J. Buelow, Buried Waste Integrated Demonstration - Technology Status Report for Supercritical Water Oxidation, TTP No. ALCL21-KO, Nov. 8, 1991.

45a. S. J. Buelow, (LANL) "Chemical Reactions of Nitrogen Containing Compounds in Supercritical Water," Proceedings, Workshop on Federal Programs Involving Supercritical Water Oxidation, Gaithersburg, MD, July 6-7, 1992, pp. 7-45.

126. S. J. Buelow, Destruction of Propellant Components in Supercritical Water, LA-UR-90-1338, May 1990.

40. P. B. Butler, N. E. Bergan, T. T. Bramlette, W. J. Pitz, C. K. Westbrook, "Oxidation of Hazardous Waste in Supercritical Water: A Comparison of Modeling and Experimental Results for Methanol Destruction," Western States Section/The Combustion Institute 1991 Spring Meeting, March 17, 1991, Boulder, Colorado.

45d. B. Chappel, "Progress on the MODEC and MODAR Supercritical Water Reactors," Proceedings, Workshop on Federal Programs Involving Supercritical Water Oxidation, Gaithersburg, MD, July 6-7, 1992, pp. 67-73.

235. T. R. Charlton, Comparison of Current Methods for Calculating Residence Time, Technology Development File ID121217/0014, March 10, 1994.

50. E. Chynoweth, "New Options Take On Incineration," Chem Week, Aug. 22, 1990, pp. 49-50.

59. P. J. Darcy, "Trip Report - Modar, Inc., Nov. 13, 1992, "Memorandum for Record, SMCWVATD (340a), Nov 23, 1992.

A26. P. C. Dell'Orco, The Separation of Particles From Supercritical Water Oxidation Effluents, Thesis, University of Texas, August 1991.

134. P. Dell'Orco, B. R. Foy, J. M. Robinson, S. Buelow, "Hydrothermal Treatment of Hanford Waste Constituents, AICHE Summer Meeting, Minneapolis, MN, Aug 9-13, 1992 (LA-UR-922508).

142. P. C. Dell'Orco, E. F. Gloyna, S. Buelow, "Oxidation Processes in the Separation of Solids from Supercritical Water," Supercritical Fluid Engineering Science, Chapter 25, American Chemical Society Symposium Series Number 514, 1993, pp. 314-326. 
107. P. C. Dell'Orco, L. Li, E. F. Gloyna, "The Separation of Particles From Supercritical Water Oxidation Effluents," 7th Symposium on Separation Science and Technology for Energy Applications, Knoxville, TN, Oct. 20-24, 1991, CONF-911049-5.

114. N. L. Dickinson, "Pollution-Free Low Temperature Combustion Process Utilizing the Supercritical State," U. S. Patent 4,380,960 April 26, 1983

115. N. L. Dickinson, "Combination of Supercritical Wet Combustion and Compressed Air Energy Storage," U. S. Patent 4,593,202 June 3, 1986

101. C. A. Eckert, G. W. Leman, H. H. Yang, "Homogeneous Catalysis for Wet Oxidation: Design and Economic Feasibility of a Mobile Detoxification Unit," Hazardous Materials Control, March-April, 1990, pp. 20-33.

16. EG\&G, Idaho, Supercritical Water Oxidation Demonstration Project Engineering Specification (Draft). (see Carolyn Shapiro for latest draft)

207. EG\&G, Idaho, Specification for Supercritical Water Oxidation Transpiring Wall Reactor BenchScale System (draft), October, 1993.

139. EPA, Engineering Bulletin on Supercritical Water Oxidation, EPA/540/S-92/006, September, 1992

85. A. G. Fassbender, "Dual Shell Pressure Balanced Vessel," U. S. Patent 5,167,930, Dec. 1, 1992.

29. H. Freeman, editor, Innovative Thermal Hazardous Organic Waste Treatment Processes, Chapter 4. Wet Oxidation, Noyes Publications, 1985.

45j. $\quad$ N. B. French, P. B. Butler, B. Schmitt, C. Westbrook, B. Pitz, "Modelling SCWO Systems," Proceedings, Workshop on Federal Programs Involving Supercritical Water Oxidation, Gaithersburg, MD, July 6-7, 1992, pp. 199-242.

222. K. M. Garcia, Pressure and Temperature as Reactor Design Factors for SCWO of DOE Wastes, EG\&G Idaho Engineering Design File, Project WTD-121217-029, EDF \#ID121217/1009. (Proprietary)

224. K. M. Garcia, Corrosion and Deposition as Design Factors for SCWO of DOE Mixed Wastes, EG\&G Idaho Engineering Design File, Project OWTD-3YH061-074-HW, EDF \#ID121217/1010.

223. K. M. Garcia, Reactor Design for SCWO of DOE Mixed Wastes, EG\&G Idaho Engineering Design File, Project WTD-121217-029, EDF \#ID121217/1011. (Proprietary)

202. K. M. Garcia, R. E. Mizia, Charles Barnes, Supercritical Water Oxidation Design Factors, EGG-WTD-11145, January, 1994. 
60. E. F. Gloyna, Description of the University of Texas Balcones Research Center (SCWO) Pilot Unit, October, 1991

32. E. Gloyna, "Destruction of Toxic Organic Materials ans Sludges by Supercritical Water Oxidation," J. Hazardous Materials 24, (1990) p. 285.

34. E. F. Gloyna, L. Li, "Supercritical Water Oxidation of Wastewaters," Environmental Solutions Program Advisory Council Meeting, The University of Texas, Balcones Research Center, Austin Texas, May 9-10, 1991.

46. E. F. Gloyna, L. Li, "SCWO of Toxic Wastewaters and Sludges," Presentation Outline, Environmental Health Engineering and Separations Research Programs, University of Texas at Austin, April 25-26, 1991.

102. E. F. Gloyna, L. Li, "SCWO: An Engineering Update," paper presented at Gulf Coast Hazardous Substance Research Center, Lamar University, Beaumont, Texas, February 1992.

252. J. Griffith, "Destruction of Aqueous Organic Wastes by SUpercritical Water Oxidation," Paper Presented at the Water Environment Association of Texas Annual Conference, June 15-17, 1994, Corpus Christi, Texas.

196. D. M. Harradine, S. J. Buelow, P. C. Dell'Orco, R. B. Dyer, B. R. Foy, J. M. Robinson, J. A. Sanchez, T. Spontarelli, J. D. Wander, Oxidation Chemistry of Energetic Materials in Supercritical Water, Hazardous Waste \& Hazardous Materials 10(2), (1993), pp.233-246.

84. G. Hartman, J. Eller, E. F. Gloyna, "Water Oxidation of Sludges and Toxic Wastes," Environ. Eng. Prog. 1989 Spec. Conf., Austin Texas, July 10-12, 1989, pp. 804-810.

152. D. A. Hazlebeck, K. W. Downey, D. D. Jensen, M. H. Spritzer, Supercritical Water Oxidation of Chemical Agents, Solid Propellants, and Other DoD Hazardous Wastes, General Atomics Report, March, 1993

14. R. K. Helling, J. W. Tester, "Oxidation of Simple Compounds and Mixtures in Supercritical Water: Carbon Monoxide, Ammonia, and Ethanol," Environ. Sci. Technol 22 (1988) pp. 1319-1324.

37. R. K. Helling, J. W. Tester, "Oxidation Kinetics of Carbon Monoxide in Supercritical Water," J. of Energy and Fuels 1, (1987) pp. 417-423.

45d. T. M. Hightower (NASA), "SCWO for Space Applications," Proceedings, Workshop on Federal Programs Involving Supercritical Water Oxidation, Gaithersburg, MD, July 6-7, 1992, pp. 74-110.

197. H. R. Holgate, J. W. Tester, Oxidation of Hydrogen and Carbon Monoxide in Sub- and Supercritical Water: Reaction Kinetics, Pathways, and Water-Density Effects. I. Experimental Results, Submitted to the J. of Phys. Chem., May, 1993. 
198. H. R. Holgate, J. W. Tester, Oxidation of Hydrogen and Carbon Monoxide in Sub- and Supercritical Water: Reaction Kinetics, Pathways, and Water-Density Effects. II. Elementary Reaction Modeling, Submitted to the J. of Phys. Chem., May, 1993.

12. G. T. Hong, "Method for Oxidation of Materials in Water At Supercritical Temperatures and Subcritical Pressures," U.S. Patent 5,106,513, April 21, 1992.

A10. G. T. Hong, P. K. Fowler, W. R. Killilea, K. C. Swallow, "SCWO: Treatment of Human Waste and System Configuration Tradeoff Study," SAE 17th Inter. Conf. on Envir. Systems, Seattle, WA, July 13-15, 1987.

13. G. T. Hong, W. R. Killilea, T. B. Thomason, "Method and Apparatus for Solids Separation in a Wet Oxidation Type Process," U. S. Patent 4,822,497, April 18, 1989

71. T. J. Houser, D. M. Tiffany, Z. Li, M. E. McCarville, M. E. Houghton, "Reactivity of Some Organic Compounds with Supercritical Water," Fuel 65(6), (1986) pp. 827-832.

106. T. J. Houser, C. C. Tsao, "Reactions of Organic Compounds with Supercritical Water Involving Chemical Oxidation," Proceedings of the First International Symposium on Chemical Oxidation: Technologies for the Ninties, Vanderbuilt University, Nashville Tennessee, Feb. 20-22, 1991, pp. 292-298.

24. T. J. Houser, C.-C. Tsao, J. E. Dyla, M. K. Van Atten, M. M. McCarville, "The Reactivity of Tetrahydroquinoline, Benzylamine, and Bibenzyl with Supercritical Water," Fuel 68, (1989) pp.323-327.

240. C.-Y. Huang, "Apparatus and Method for Supercritical Water Oxidation," U. S. Patent 5,100,560, March 31, 1992.

122. G. P. Jacobs, H. E. Barner, A. L. Bourhis, "Utilization of PHOENICS in the Design of the MODAR SCWO Reactor," Presented at the AICHE 1992 Annual Meeting, Miami Beach, Florida, Nov. 1-6, 1992.

74. L. Jin, M. A. Abraham, "Catalytic SCWO of 1,4-Dichlorobenzene," Chem Eng. Sci. 47(9-11) (1992) pp. 2659-2664.

19. L. Jin, Y. T. Shah, M. A. Abraham, "The Effect of Supercritical Water on the Catalytic Oxidation of 1,4-Dichlorobenzene," J. Supercritical Fluids 3, (1990) pp. 233-239.

51. J. B. Johnson, R. E. Hannah, V. L. Cunningham, B. P. Daggy, F. J. Sturm, R. M. Kelley, "Destruction of Pharmaceutical and Biopharmaceutical Wastes by the Modar SCWO Process," Bio/Technology 6, Dec. 1988, pp. 1423-1427.

53. K. P. Johnston, C. Haynes, "Extreme Solvent Effects on Reaction Rate Constants at Supercritical Fluid Conditions," AIChE Journal 33 (1987), pp. 2017-2026.

91. J. Josephson, "Supercritical Fluids," Environ. Sci. Technol. 16(10), (1982), pp. 548A-551A. 
52. W. R. Killilea, K. C. Swallow, G. T. Hong, "The Fate of Nitrogen in SCWO," J. Supercritical Fluids 5, (1992) pp. 72-78.

121. W. R. Killilea, G. T. Hong, K. C. Swallow, T. B. Thomason, "Supercritical Water Oxidation: Microgravity Solids Separation," SAE Technical Series Paper \#881038, 18th Intersociety Conference on Environmemtal Systems, San Francisco, CA, July 11-13, 1988

125b. M. E. Kim-E, R. C. Reid, "The Rapid Depressurization of Hot, High Pressure Liquids or Supercritical Fluids," Chemical Engineering at Supercritical Fluid Conditions, Chapter 3, Ann Arbor Science, 1983

45e. R. E. Kirts, "SCWO of Hazardous Waste," Proceedings, Workshop on Federal Programs Involving Supercritical Water Oxidation, Gaithersburg, MD, July 6-7, 1992, pp. 111-137.

67. M. T. Klein, L. A. Torry, B. C. Wu, S. H. Townsend, S. C. Paspek, "Hydrolysis in Supercritical Water: Solvent Effects as a Probe of the Reaction Mechanism," I. Supercritical Fluids 3, (1990) pp. 222-227.

193. C. A. LaJeunesse, J. P. Chan, T. N. Raber, D. C. Macmillan, S. F. Rice, K. L. Tschritter, Supercritical Water Oxidation of Colored Smoke, Dye, and Pyrotechnic Compositions, Final Report: Pilot Plant Conceptual Design, SAND94-8202, November, 1993.

194. C. A. LaJeunesse, S. F. Rice, R. G. Hanush, J. D. Aiken, Salt Deposition Studies in a Supercritical Water Oxidation Reactor, (Interim Report), SAND94-8201, October, 1993.

195. C. A. LaJeunesse, S. F. Rice, J. J. Bartel, M. Kelley, C. A. Seibel, L. G. Hoffa, T. F. Eklund, B. C. Odegard, A Supercritical Oxidation Reactor: THe Material Evaluation Reactor (MER), SAND91-8623, November, 1992.

75. D. S. Lee, E. F. Gloyna, "Hydrolysis and Oxidation of Acetamide in Supercritical Water," Envir. Sci. Technol. 26(8), (1992) 1587-93

21. D. S. Lee, E. F. Gloyna, L. Li, "Efficiency of $\mathrm{H}_{2} \mathrm{O}_{2}$ and $\mathrm{O}_{2}$ in Supercritical Water Oxidation of 2,4-Dichlorophenol and Acetic Acid," J. Supercritical Fluids 3, (1990) pp. 249-255.

25. L. Li, P. Chen, E. F. Gloyna, "Generalized Kinetic Model for Wet Oxidation of Organic Compounds," AIChE Journal 37, (1991) pp. 1687-1697.

25a. L. Li, P. Chen, E. F. Gloyna, "Kinetic Model for Wet Oxidation of Organic Compounds in Subcritical and Supercritical Water," Supercritical Fluid Engineering Science, Fundamentals and Applications, ASC Syposium Series 514, pp. 305-313.

31. L. Li, E. F. Gloyna, "A Reciprocating Pump Check Valve Designed for SCWO of Sludges," J. Hazardous Materials 24, (1990) pp. 77-82.

154. R. Li, P. E. Savage, D. Szmukler, "2-Chlorophenol Oxidation in Supercritical Water: Global Kinetics and Reaction Products," AIChE Joumal 39, January, 1993, pp.178-187. 
216. K. Liebelt, Thermal Analysis of a SCWO Preheater and Cool-Down Heat Exchanger, EG\&G Idaho Engineering Design File, Project WTD-121217-029, EDF \#ID12121217/1008, December 10, 1993.

45m. R. T. Loda, DARPA Supercritical Fluid Related Tasks," Proceedings, Workshop on Federal Programs Involving Supercritical Water Oxidation, Gaithersburg, MD, July 6-7, 1992, pp. 255-286.

136. S. B. Margolis, S. C. Johnston, "Nonadiabaticity, Stoichiometry, and Mass Diffusion Effects on Supercritical Combustion in a Tubular Reactor," Twenty-Third International Symposium on Combustion, University of Orleans, Orleans, France, July 22-27, 1990, pp. 533-541.

205. R. W. Marshall, Jr., Power Fluidic Equipment Brochures Including Mixers, and Vortex Control Valves From British Nuclear Fuels Limited, Environmental Restoration and Waste Management OTD Technology Development File TD121217/1013, November 22, 1993.

43. R. D. McFarland, G. R. Brewer, C. K Rofer, Design and Operational Parameters of Transportable Supercritical Water Oxidation Waste Destruction Unit, LA-12216-MS, UC-940, December, 1991.

135. C. F. Melis, N. E. Bergan, J. E. Shepherd, "Effects of Water on Combustion Kinetics at High Pressure," Twenty-Third International Symposium on Combustion, University of Orleans, Orleans, France, July 22-27, 1990, pp. 217-223.

125f. J. O. Metzger, J. Hartmanns, D. Malwitz, P. Koll, "Thermal Organic Reactions in Supercritical Fluids," Chemical Engineering at Supercritical Fluid Conditions, Chapter 26, Ann Arbor Science, 1983

226. J. C. Meyer, Oxidation Chemistry and Kinetics of Model Compounds in Supercritical Water: Glucose, Acetic Acid, and Methylene Chloride, AD-A266 564, June, 1993.

44. Modell Development Corporation, "SCWO For Military Applications," Presentation for U. S. Department of Defense, Thiokol Corp., September 1, 1992.

47. Modell Development Corporation, Technical Solutions for Today's Environment: Supercritical Water Oxidation, undated

5. Modell Development Corporation, "Development of a SCWO System, Phase IIIA, "Proposal to the U.S. Department of Energy Office of Technology Development, December 4, 1991.

212. Modell Development Corporation, "Supercritical Water Oxidation Process and Apparatus of Organics with Inorganics," International Patent Application WO 93/00304, January 7, 1993.

204. M. Modell, Assessment and Development of an Industrial Wet Oxidation System for Burning Waste and Low-Grade Fuels, Final Report, DOE/ID/12915/FIN, December, 1993 
190. M. Modell, "Supercritical Water Oxidation (SCWO)," Draft of paper presented at Wastech '92, September, 1992

6. M. Modell, Treatment of Pulp Mill Sludges by SCWO: Final Report, DOE/CE/40914-T1, July, 1990.

10. M. Modell, "Processing Methods for the Oxidation of Organics in Supercritical Water," U.S. Patent 4,338,199, July 6, 1982.

68. M. Modell, "Processing Methods for the Oxidation of Organics in Supercritical Water," Amendment to U.S. Patent 4,338,199, Dec. 6, 1988.

11. M. Modell, "Processing Methods for the Oxidation of Organics in Supercritical Water," U.S. Patent 4,543,190, Sept. 24, 1985.

54. M. Modell, "Supercritical Water Oxidation," Standard Handbook of Hazardous Waste Treatment and Disposal, H. F. Freeman, editor, Mc-Graw Hill Book Co., 1988.

153. M. Modell, G. G. Gaudet, M. Simson, G. T. Hong, K. Biemann, "Destruction of Hazardous Waste Using Supercritical Water," ??????, pp. 202-212

239. M. Modell, E. F. Kuharich, M. R. Rooney, "Supercritical Water Oxidation Process and Apparatus of Organics with Inorganics," U. S. Patent 5,252,224, October 12, 1993.

191. J. Mohiuddin, National Supercritical Water Oxidation Program Steering Committee Meeting, Summary of Proceedings, December. 2, 1993.

146. R. C. Moore, J. M. Simonson, A Review of Supercritical Water Oxidation Research and Technology, ORNL/CF-93/39, February, 1993.

232. S. Moore, S. Samdani, G. Ondrey, G. Parkinson, New Roles for Supercritical Fluids, Chemical Engineering, March 1994, pp. 32-35.

182. M. Mukhorpadhyay, G. V. R. Rao, "Thermodynamic Modeling for Supercritical Fluid Process Design," Ind. Eng. Chem. Res. 32(5), 1993, pp. $922-930$

148. B. C. Norby, Supercritical Water Oxidation Benchscale Testing Metallurgical Analysis Report, EGG-WTD-10675.

206. C. H. Oh, "Residence Time for Transpired Platelet Reactor Concept," Environmental Restoration and Waste Management OTD Technology Development File, ID121217/1012, November 16, 1993.

125. M. E. Paulaitis, J. M. L. Penninger, R. D. Gray, Jr., P. Davidson, editors, Chemical Engineering at Supercritical Fluid Conditions, Ann Arbor Science, 1983. (Chapters listed separately, 125a-125f) 
95. W. A. Propp, A. E. Grey, J. Negus-de Wys, M. M. Plum, D. R. Haefner, Feasibility Study: Application of the Geopressured-Geothermal Resource to Pyrolytic Conversion or Decomposition/Detaxification Processes, EGG_EP-9842, September, 1991.

27. S. Ramayya, A. Britain, C. DeAlmeida, W. Mok, M. J. Antal, Jr., "Acid-Catalyzed Dehydration of Alcohols in Supercritical Water," Fuel 66, (1987) pp. 1364-1371.

246. A. G. Ramos, Preliminary Hazard Classification for the Supercritical Water Oxidation Test Bed, EGG-WTD-11316, May, 1994.

192. S. F. Rice, R. R. Steeper, C. A. LaJeunesse, Destruction of Representative Navy Wastes Using Supercritical Water Oxidation, SAND94-8203, October, 1993.

45h. C. Robinson, "Demilitarization R\&D Technology for Conventional Munitions via SCWO of Colored Smokes, Dyes, and Pyrotechnics," Proceedings, Workshop on Federal Programs Involving Supercritical Water Oxidation, Gaithersburg, MD, July 6-7, 1992, pp. 160-175.

245. J. M. Robinson, B. R. Foy, P. C. Dell'Orco, G. Anderson, F. Archuleta, J. Atencio, D. Breshears, R. Brewer, H. Eaton, R. McFarland, R. McInroy, T. Reynolds, M.Sedillo, E. WIImanns, S. J. Buelow, "Destruction of Nitrates, Organics, and Ferrocyanides by Hydrothermal Processing," Proceedings pf the Symposium on Waste Management at Tucson, Arizona, February 28-March 4, 1993, pp. 709-716.

45g. A. T. Rodriguez, "SCWO System Development," Proceedings, Workshop on Federal Programs Involving Supercritical Water Oxidation, Gaithersburg, MD, July 6-7, 1992, pp. 138-159.

94. C. K. Rofer, Kinetics Experiments and Bench-Scale System - Background, Design and Preliminary Experiments, LA-11106-MS, September 30, 1987.

105. C. K. Rofer, "Supercritical Water Oxidation," Proceedings of the First International Symposium on Chemical Oxidation: Technologies for the Ninties, Vanderbuilt University, Nashville Tennessee, Feb. 20-22, 1991, pp. 278-291.

58. C. K. Rofer, "Supercritical Water Oxidation For Treatment of Mixed Wastes," Waste Management '91, Vol 1, pp. 931-934.

57. C. K. Rofer, G. E. Streit, Kinetics and Mechanism of Methane Oxidation in Supercritical Water, LA-11439-MS DOE/HWP-64, October 1988.

33. C. K. Rofer, G. E. Streit, Phase II Final Report: Oxidation of Hydrocarbons and Oxygenates in Supercritical Water, LA-11700-MS DOE/HWP-90, September 1989.

A28. S. Rollans, L. Li, E. F. Gloyna, "Separation of Hexavalent and Trivalent Chromium From SCWO Effluents," Emerging Technologies for Hazardous Waste Management, 1992 Book of Abstracts for the Special Symposium, Atlanta, I\&E Chemistry Division, ACS, Sept. 22-23, 1992, p. 707. 
451. G. J. Rosasco, "Army Research Office University Research Initiative in SCWO - An Unofficial Summary, "Proceedings, Workshop on Federal Programs Involving Supercritical Water Oxidation, Gaithersburg, MD, July 6-7, 1992, pp. 249-254.

127. R. G. Schmitt, P. B. Butler, C. K. Westbrook, W. J. Pitz, "Destruction of Hazardous Wastes in Supercritical Water," 1991 Fall Meeting of the Western States Section/The Combustion Institute, Los Angeles, CA, Oct. 13-15, 1991 UCRL-JC-108654 Part 2.

45i. R. L. Schneider and B. A. Donahue, "Identification and Assessment of Environmentally Safe Alternative Technologies to Open Burning/Open Detonation Destruction of Explosive and Propellant Production Wastes," Proceedings, Workshop on Federal Programs Involving Supercritical Water Oxidation, Gaithersburg, MD, July 6-7, 1992, pp. 177-198.

45k. J. M. H. L. Sengers, "NIST Programs Relevant to SCWO," Proceedings, Workshop on Federal Programs Involving Supercritical Water Oxidation, Gaithersburg, MD, July 6-7, 1992, pp. 214-248.

30. A. Shanableh, E. F. Gloyna, "Supercritical Water Oxidation - Wastewaters and Sludges," Water Science and Technology 23, (1991), 389-398.

A25. A. Shanableh, E. F. Gloyna, "Subcritical and Supercritical Water Oxidation of Industrial, Excess Activated Sludge," University of Texas Doctoral Thesis, 1990.

183. C. Shapiro, "SCWO Hazardous Waste Pilot Plant (HWPP) Data Recommendations," EG\&G Engineering Design File, Project OWTD-3YH061-074-HW, EDF ID121212/12

201. C. Shapiro, Supercritical Water Oxidation System Study, EGG-WTD-10983, October, 1993.

141. C. Shapiro, K Garcia, J. Beller, Treatment of Simulated Mixed Waste with Supercritical Water Oxidation, EGG-WTD-10700, March 1993 (Draft)

167. C. Shapiro, K Garcia, J. Beller, "Treatment of a Simulated Mixed Waste with Supercritical Water Oxidation," Proceedings of the Second International Symposium on Mixed Waste, Baltimore, Maryland, August 17-20, 1993, pp. 10.3.1-10.3.16.

3. R. W. Shaw, T. B. Brill, A. A. Clifford, C. A. Eckert, E. U. Franck, "Supercritical Water - A Medium for Chemistry," Chemical and Engineering News, December 23, 1991, pp. 26-39.

7. J. S. Shuen, V. Yang, C. C. Hsiao, "Combustion of Liquid-Fuel Droplets in Supercritical Conditions," Combustion and Flame 89, (1992) pp. 299-319.

72. C. N. Staszak, K. C. Malinowski, W. R. Killilea, "The Pilot-Scale Demonstration of the Modar Oxidation Process for the Destruction of Hazardous Organic Waste Materials," Environ. Prog. 6(1) (1987) 39 
45b. R. Steeper, SCWO Experiments at Sandia National Laboratory, Proceedings, Workshop on Federal Programs Involving Supercritical Water Oxidation, Gaithersburg, MD, July 6-7, 1992, pp. 46-57.

150. R. R. Steeper, S. F. Rice, M. S. Brown, S. C. Johnston, "Methane and Methanol Diffusion Flames in Supercritical Water," J. Supercritical Fluids, 1992, 5, pp. 262-268.

120. Stone \& Webster Engineering Corporation, Assessment and Development of an Industrial Wet Oxidation System For Burning Waste and Low-Grade Fuels - Final Report, DOE/TD/12711-1, September, 1989

234. Stone \& Webster Engineering Corporation, Proposal for Federal Financial Assistance Award to Perform Supercritical Water Oxidation Data Acquisition Testing, March 8, 1994 (also attached are Proposal Evaluation Criteria by C. Shapiro and Summary of Technical Evaluation of the Proposal, CS-02-94, and Supplemental Information, March 25, 1994).

45n. H. Strauch, "Office of Environmental Restoration and Waste Management Initiatives in SCWO," Proceedings, Workshop on Federal Programs Involving Supercritical Water Oxidation, Gaithersburg, MD, July 6-7, 1992, pp. 287-299.

28. B. Subramaniam, M. A. McHugh, "Reactions in Supercritical Fluids - A Review," Ind. Eng. Chem Process Des. Dev. 25, (1986), pp. 1-25.

242. J. M. Svoboda, Supercritical Water Oxidation Hazardous Waste Pilot Plant Data Quality Plan, EGG-WTD-11023, February, 1984.

247. J. M. Svododa, D. J. Valentich, Design Requirements for the Supercritical Water Oxidation Test Bed, Revision 0, EGG-WTD-11199, May, 1994.

108. K. C. Swallow, W. R. Killilea, "Comment on 'Phenol Oxidation in Supercritical Water: Formation of Dibenzofuran, Dibenza-p-dioxin, and Related Compounds', Environ. Sci. Technol. 26(9), (1992) pp. 1849-1850.

113. K. C. Swallow, W. R. Killilea, G. T. Hong, H-W. Lee, "Behavior of Metal Compounds in the SCWO Process," SAE Transactions 99(1) (1990) pp. 842-847.

112. Y. Takahashi, T. Wydeven, C. Woo, "Subcritical and Supercritical Water Oxidation of CELESS Model Wastes," Adv. Space Research 9(8), (1989) pp. 99-110.

61. J. W. Tester, J. G. Harris, H. J. Herzog, J. B. Howard, R. M. Latanision, W. A. Peters, A. F. Sarofim, Chemical Reactors for Supercritical Water Oxidation of Military Taxic Wastes: A Program of Fundamental and Applied Research, University Research Initiative Submitted to the U. S. Army Research Office, July 10, 1991. 
1. J. W. Tester, H. R. Holgate, F. J. Armellini, P. A. Webley, W. R. Killilea, G. T. Hong, H. E. Barner, "SCWOTechnology: A Review of Process Development and Fundamental Research," 1991 ACS Symposium Series Paper on Emerging Technologies for Hazardous Waste Management, October 1-3, 1991, Atlanta Georgia, (draft).

177. J. W. Tester, H. R. Holgate, F. J. Armellini, P. A. Webley, W. R. Killilea, G. T. Hong, H. E. Barner, "SCWO Technology: A Review of Process Development and Fundamental Research," 1991 ACS Symposium Series Paper on Emerging Technologies for Hazardous Waste Management, October 1-3, 1991, Atlanta Geongia, revised March 25, 1993.

227. J. W. Tester, P. A: Webley, H. R. Holgate, "Revised Global Kinetic Measurements of Methanol Oxidation in Supercritical Water," Ind. Eng. Chem. Res. 32 (1993), 236-239.

69. T. B. Thomason, G. T. Hong, K. C. Swallow, W. R. Killilea, "The MODAR Supercritical Water Oxidation Process," Innovative Hazardous Waste Treatment Technol. Ser. 1 (Thermal Processes) pp. 31-42.

42. T. B. Thomason and M. Modell, "Supercritical Water Oxidation of Aqeous Wastes," Hazardous Waste 1, (1984) pp. 453-467

22. T. T. Thornton and P. E. Savage, "Phenol Oxidation in Supercritical Water," J. Supercritical Fluids 3, (1990) pp. 240-248.

23. T. T. Thornton and P. E. Savage, "Kinetics of Phenol Oxidation in Supercritical Water," AIChE Joumal 38, (1992) pp. 321-327.

116. J. A. Titmas, "Method and Apparatus for Enhancing Chemical Reactions at Supercritical Conditions," U. S. Patent 4,792,408, Dec. 20, 1988

117. J. A. Titmas, "Method and Apparatus for Conducting Chemical Reactions at Supercritical Conditions," U. S. Patent 4,594,164, June 10, 1986

A24. C. Tonghamachart, E. F. Gloyna, "Supercritical Water Oxidation of Anaerobically Digested Municipal Sludge," University of Texas Doctoral Thesis, 1990.

70. S. H. Townsend, M. A. Abraham, G. L. Huppert, M. T. Klein, S. C. Paspek, "Solvent Effects During Reactions in Supercritical Water," Ind. Eng. Chem. Res. 27, (1988) 143

A22. C. C. Tsao, Y. Zhou, X. Liu, T. J. Houser, "Reactions of SCW with Benzaldehyde, Benzylidenebenzylamine, Benzyl Alcohol, and Benzoic Acid," '

J. Supercrit. Fluids 5, (1992) pp. 107-113.

189. U.S. Army Research Office, Aqua Fortis Volume 2, No. 3 (Articles on SCWO Corrosion Workshop at MIT, Alternatives for Chemical Weapons Disposal, and a list with addresses and phone numbers of SCWO researchers) 
230. D. J. Vallentich, Specification for the Procurement of a Supercritical Water Oxidation Transpiring Wall Reactor and Liquid and Gas Separation Vessel, ES 51531, Rev. A.

45c. G. Varga, "DOE's Quest for Energy Recovery Using SCWO," Proceedings, Workshop on Federal Programs Involving Supercritical Water Oxidation, Gaithersburg, MD, July 6-7, 1992, pp. 58-66.

36. P. A. Webley, J. W. Tester, "Oxidation Kinetics of Methanol in Supercritical Water," SAE 20th Intersociety Conference on Environmental Systems, Williamsburg, Virginia, July 9-12, 1990, (also submitted for publication in ACS Symposium Series "Supercritical Fluid Science and Technology," 1989.

17. P. A. Webley, J. W. Tester, H. R. Holgate, "Oxidation Kinetics of Ammonia and AmmoniaMethanol Mixtures in Supercritical Water in the Temperature Range $530-700^{\circ} \mathrm{C}$ at 246 Bar," Ind. Eng. Chem. Res. 30, (1991), pp. 1745-1754.

35. P. A. Webley, J. W. Tester, "Fundamental Kinetics of Methane in Supercritical Water," to be published in Energy and Fuels, Dec. 1990.

39. P. A. Webley, J. W. Tester, "Fundamental Kinetics and Mechanistic Pathways for Oxidation Reactions in Supercritical Water," SAE 20th Intersociety Conference on Environmental Systems, San Francisco, California, July 11-13, 1988.

118. J. F. Welch, J. D. Siegwarth, "Method for the Processing of Organic Coumpounds," U. S. Patent 4,861,497 August 29, 1989

243. H. J. Welland, "Orifice Plates to Help Reduce Pressure," EG\&G Engineering Design File, Project WTD 121217-088, Number ID121217/2003, May 6, 1994,

188. Roy F. Weston, Inc., Supercritical Fluid (SCF) Technologies: Assessment of Applicability to Installation Restoration Processes, Draft Final Report, U.S. Army Environmental Center Report SFIM-AEC-TS-CR-93127, November, 1993

124. R. A. Wills, "Three High Temperature Methods for Hazardous Waste Disposal," Spring National Meeting of the AICHE, Houston, TX, March 29-April 2, 1987.

20. X. Xu, C. De Almeida, M. J. Antal, Jr., "Mechanism and Kinetics of the Acid-Catalyzed Dehydration of Ethanol in Supercritical Water," J. Supercritical Fluids 3, (1990) pp. 228-232.

18. H. H. Yang, C. A. Eckert, "Homogeneous Catalysis in the Oxidation of $p$-Chlorophenol in Supercritical Water," Ind. Eng. Chem. Res. 27, (1988), pp. 2009-2014.

236. D. Yu, M. Aihara, M. J. Antal, Jr., "Hydrogen Production by Steam Reforming Glucose in Supercritical Water," Energy \& Fuels 7 (1993) pp. 574-577.

119. J. E. Zeigler, H. W. Peterscheck, "Method for Wet Oxidation Treatment, U. S. Patent 4,891,139 January 2, 1990 
A17. "New Waste-Destruction Method Takes Aim at World's Sludge," Res. \& Dev., Feb, 1992, pp. 98-100.

A6. "New Way to Destroy Aqueous Toxid Wastes," Nat. Eng. 94(10), (1990) pp. 8-10.

63. Research on Toxic Molecules in Supercritical Water, Aqua Fortis I(2) (US Army Research Office) Nov. 1992.

253. SRP Spnsor EWT Now Operating First Commercial SCWO at Huntsman Chemical," Separations Update, Spring, 1994.

9. "Supercritical Method as Waste Detoxifier," Chemical and Engineering News, July 16, 1990, p. 24.

A15. "SCWO: An Emerging Waste Treatment Technology," Ind. Health \& Haz. Update 92(11)

A16. "SCWO: Weapon for Destroying Organic Wastes," Futuretech 152, Aug. 17, 1992

A12. "SCW System Gets a Vote of Confidence at Sandia," Chem. Eng. 97, p. 19.

A18. "Sludge Disposal by New Process Seems Cost-Effective, Environmentally Sound," American Papermaker, October, 1991, pp. 40-41.

A14. "Using SCW to Destroy Tough Wastes," Chem. Week 130(16), (1982) p. 26.

\section{SUPERCRITICAL FLUID EXTRACTION}

92. C. A. Eckert, J. G. Van Alsten, T. Stoicos, "Supercritical Fluid Processing," Environ. Sci. Technol. 20(4), (1986) pp. 319-325.

A20. D. J. Ehntholt, C. P. Eppig, K. E. Thron, Isolation and Concentration of Organic Substances From Water: An Evaluation of Supercritical Fluid Extraction, EPA/600/1-84/028, 1984

26. D. Ghonasgi, S. Gupta, K. M. Dooley, F. C. Knopf, "Supercritical $\mathrm{CO}_{2}$ Extraction of Organic Contaminants from Aqueous Streams," AIChE Joumal 37, (1991) pp. 944-950.

A7. D. Ghonasgi, M. Ye, K. M. Dooley, F. C. Knopf, "High Pressure Solvent Extraction Catalytic Oxidation of Hazardous Wastes from Aqueous Streams," Joumal of Haz. Materials 24, (1990) pp. 291-292.

15. R. J. Robley, Liquid Carbonic Supercritical Processing Group, Letter to R. W. Marshall, Jr., Nov. 20, 1992 with attached paper "Rerefining of Used Oil: A New Technology Step in Supercritical Gas Extraction," by H. Coenen.

A21. J. C. Wallace, M. S. Krieger, R. A. Hites, "Reduction of Contamination Levels in On-Line Supercritical Fluid Extraction Systems," Anal. Chem. 64(12), pp. 2655-2655. 
A19. "Supercritical Processes Win CPI Acceptance," Chemical Engineering, July, 1989, pp. 35-39

N22. "Supercritical Fluids: Glitsch/Phasex Combination Advances Supercritical Fluid Extraction Processes," High Tech Sep News 4(12), May, 1992

N25. "Supercritical Fluids: SKW Chemicals Provides Leadershipin Supercritical Carbon Dioxide Processing," High Tech Sep News 4(7), Dec. 1991.

N26. "Supercritical Fluid Extraction Considered by Canada," High Tech Sep News 4(6), Nov 1991.

103. "Freon Solvent Replacement: Supercritical $\mathrm{CO}_{2}$ for Precision Parts Cleaning," Technology Transfer Bulletin, MT92035EN-DEC, Air Force Materiel Command

\section{MATERIAIS \& CORROSION}

213. K. M. Garcia, "Remote Measurement of Corrosion in SCWO," EG\&G, Idaho, Inc. Engineering Design File ID121717-1003, October 7, 1993

215. K. M. Garcia, R. Mizia, Trip Report for Nov. 16 through Nov. 19 to Various Meetings, November 22, 1993.

241. K. M. Garcia, "Status Report on Penn State Development of Instrumentation for Electrochemical Measurement of Corrosion in SCWO," EG\&G, Idaho, Inc. Engineering Design File ID121717-1025, June 15, 1994

8. A. J. Klein, T. M. Sullivan, "Liquid Ceramic Process Makes Better Components," Advanced Materials \& Processes, August 1992, pp. 35-38.

220. R. M. Latanision, R. W. Shaw, Corrosion in Supercritical Water Oxidation Systems: Workshop Summary, MIT-EL 93-006, September, 1993.

143. C. F. Matthews, E. F. Gloyna, Corrosion Behavior of Three High-Grade Alloys in Supercritical Water Oxidation Environments, Center for Research in Water Resources Bureau of Engineering Research, University of Texas at Austin Technical Report CRWR 234, June, 1992.

187. R. E. Mizia, Trip Report - MIT Workshop - Corrosion in Supercritical Water Oxidation, INEL Correspondence REM-05-93, June 21, 1993.

187a. R. E. Mizia, Additional Comments on Degradation of Ceramics in Supercritical Water, INEL Correspondence REM-08-93, July 29, 1993.

144. A. J. Thomas, III, E. F. Gloyna, Corrosion Behavior of High-Grade Alloys in Supercritical Water Oxidation of Sludges, Center for Research in Water Resources Bureau of Engineering Research, University of Texas at Austin Technical Report CRWR 229, February, 1991. 
147. G. Thurston, K Garcia, Supercritical Water Oxidation Pump Investigation, EGG-WTD-10674, February, 1993.

151. M. Valenti, Retrofitting Plants with Low NO $\mathrm{x}_{x}$ Burners, Mechanical Engineering, May, 1993, pp. 76-79.

\section{PHYSICAL AND CHEMICAL PROPERTIES}

62. N. E. Bergan, C. F. Melius, H. A. Dwyer, "Studies of Thermodynamic Non-Ideality Effects on Chemical Equilibrium and Oxidation in Supercritical Fluids," Chem. Phys. Processes Combust. 1989 pp. 23-1 - 23-3.

A3. R. Burk, P. Kruus, "Solubilities of Solids in Supercritical Fluids," Can. J. of Chem. Eng. 70, (1992) pp. 403-407.

131. F. Franks, editor, Water, $A$ Comprehensive Treatise, Plenum Press, 1972 (only table of contents, references, and Chapter 13 "Water at High Temperatures and Pressures" by $\mathrm{K}$. Todheide are in file).

130. A. H. Harvey, J. M. H. Levelt Sengers, "Comment on the $\mathrm{NaCl}-\mathrm{H}_{2} \mathrm{O}$ Coexistence Curve Near the Critical Temperature of $\mathrm{H}_{2} \mathrm{O}, "$ Chemical Physics Letters 156(4) (1989) pp. 415-417.

125e. G. T. Hong, M. Modell, J. W. Tester, "Binary Phase Diagrams From a Cubic Equation of State," Chemical Engineering at Supercritical Fluid Conditions, Chapter 13, Ann Arbor Science, 1983.

128. M. L. Japas, J. M. H. Levelt Sengers, "Gas Solubility and Henry's Law Near the Solvent's Critical Point," AICHE Joumal 35(5), May, 1989, pp.705-713.

249. W. J. Lamb, G. A. Hoffman, J. Jones, "Self-Diffusion in Compressed Supercritical Water," J. Chem. Phys 74(12), June 15, 1981, pp. 6875-6880.

55. O. I. Martynova, "Solubility of Inorganic Compounds in Subcritical and Supercritical Water," High Temperature, High Pressure Electrochemistry in Aqueous Solutions, D. deG. Jones and R. W. Staehle, eds. Houston:National Association of Corrosion Engineers, 1976, pp.131-138.

110. Master Chemical Corporation, Bulletin with TRIMTMSOL toxicity, manufacturer, regulatory, physical property, safety, and health hazard information

125c. M. A. McHugh, M. W. Mallett, J. P. Kohn, "High Pressure Fluid Phase Equilibria of AlcoholWater-Supercritical Solvent Mixtures," Chemical Engineering at Supercritical Fluid Conditions, Chapter 5, Ann Arbor Science, 1983.

49. S. Mitra, N. K. Wilson, "Empirical Method to Predict Solubility in Supercritical Fluids," J. of Chrom. Science 29(7), (1991) pp. 305-309. 
182. M. Mukhopadhyay, G. V. Raghuram Rao, "Thermodynamic Modeling for Supercritical Fluid Process Design," Ind. Eng. Chem. Res. 32, 1992, pp. 922-930.

214. E. H. Oelkers, H. C. Helgeson, "Multiple Ion Association in Supercritical Aqueous Solutions of Single Electrolytes," Science 261, August 13, 1993, pp. 888-891.

73. C. J. Parisod, E. Plattner, "Vapor-Liquid Equilibrium on the $\mathrm{NaCl}-\mathrm{H}_{2} \mathrm{O}$ System in the Temperature Range $300-400^{\circ} \mathrm{C},{ }^{"} J$. Chem. Eng. Data 26, (1981) 16

65. C. J. Peters, J. DeS. Arons, "On the Relationship Between the Carbon-Number of NParaffins and their Solubility in Supercritical Solvents," Fluid Phase Equilibria 52, (1989) pp. 389-396.

66. C. J. Peters, H. J. Van Der Kooi, J. L. De Roo, J. DeS. Arons, J. S. Gallagher, J. M. H. Levelt Sengers, "The Search for Tricriticality in Binary Mixtures of Near-Critical Propane and Normal Paraffins," Fluid 'Phase Equilibria 51, (1989) pp. 339-351.

125d. J. C. Rainwater, M. R. Moldover, "Thermodynamic Models for Fuild Mixtures Near Critical Conditions," Chemical.Engineering at Supercritical Fluid Conditions, Chapter 10, Ann Arbor Science, 1983

129. J. M. H. Levelt Sengers, "Solubility Near the Critical Point," J. of Supercritical Fluids 4 (1991) pp. 215-222.

111. S. Souriajan, G. C. Kennedy, "The System $\mathrm{H}_{2} \mathrm{O}-\mathrm{NaCl}$ at Elevated Temperatures and Pressures," Amer. J. Sci. 260, (1962) 115

125a. W. B. Streett, "Phase Equilibria in Fluid and Solid Mixtures at High Pressure," Chemical Engineering at Supercritical Fluid Conditions, Chapter 1, Ann Arbor Science, 1983

\section{DOE WASTES \& WASTE MANAGEMENT}

200. C. M. Barnes, Mixed Waste Survey for the Supercritical Water Oxidation Program, EGG-WTD10984, November, 1993.

123. C. M. Barnes, "Selection of DOE Mixed Wastes to Serve as a Basis for SCWO Tests," EG\&G Idaho Engineering Design File, Project 015581-B, EDF \#2.0, January 26, 1993.

179. C. M. Barnes, "Mixed Waste Characterization Data and Basis for HWPP Simulated Waste Definition," EG\&G Idaho Engineering Design File, Project OWTD-3YH061-074-HW, EDF ID121217/9, August 12, 1993.

180. C. M. Barnes, "Hazardous Waste Pilot Plant Test Waste Definition," EG\&G Idaho Engineering Design File, Project OWTD-3YH061-074-HW, EDF ID121217/11, August 12, 1993. 
181. C. M. Barnes, "Characterization Recommendations," EG\&G Idaho Engineering Design File, Project OWTD-3YH061-074-HW, EDF ID121217/10, August 12, 1993.

145c. J-A. Bassi, M. S. Abashian, S. Chakraborti, M. Devarakonda, S. M. Djordjevic, "A Decision Methodology fo the Evaluation of Mixed Low-Level Radioactive Waste Management Options for DOE Sites," Fourteenth Annual U.S. Department of Energy Low-Level Radioactive Waste Management Conference, Phoenix, Arizona, Nov. 18-20, 1992, pp. 428-432.

170. S. Chakraborti, T. DeBiase, "Transportaition of Liquid Mixed Waste in the U.S.: Is it Really a Problem?," Proceedings of the Second International Symposium on Mixed Waste, Baltimore, Maryland, August 17-20, 1993, pp. 12.3.1-12.3.8.

82. E. C. Garcia, "LDR Mixed Waste Characterization and Categorization," EG\&G Idaho EDF, Project File C1.10, EDF \#058, Jan. 2, 1991 (See Carolyn Shapiro for this EDF).

145b. T. W. Garrison, M. Lynn Apel, C. M. Owens, "Treatment of DOE and Commercial Mixed Waste by the Private Sector," Fourteenth Annual U.S. Department of Energy Low-Level Radioactive Waste Management Conference, Phoenix, Arizona, Nov. 18-20, 1992, pp. 341-349.

98. L. H. Harmon, J. E. Rhoderick, L. C. Borduin, B. C. Musgrave, W. A. Ross, "Technology Needs for Treatment of DOE's Low-Level Mixed Wastes," Waste Management 92, Volume 2, Proceedings of the Symposium on Waste Management at Tucson, Arizona, March 1-5, 1992, pp. 1137-1142

156. T. L. Harris, S. M. Steele, H. A. Bohrer, T. W. Garrision, C. M. Owens, "Private Sector Participation for the Treatment of DOE and Commericial Radioactive Mixed Wastes," Proceedings of the Second Intemational Symposium on Mixed Waste, Baltimore, Maryland, August 17-20, 1993, pp. 2.1.1-2.1.29.

159. V. Loiselle, B. C. Warren, "LSV Waste Disposal: A Successful Commercial Mixed Waste Treatment License and Permit," Proceedings of the Second International Symposium on Mixed Waste, Baltimore, Maryland, August 17-20, 1993, pp. 3.5.1-3.5.7.

89. G. H. McCabe, "Understanding the Problems Associated With Managing Commercial Mixed Low-Level Radioactive Waste," Waste Management '90, Vol. 1, pp. 731-736.

96. L. J. Mezga, B. M. Eisenhower, "Overview of Mixed Waste Issues at the Defence Installations of the United States Department of Energy," Management of Low and Intermediate Level Radioactive Wastes 1988, Volume 1, Proceedings of a Symposium in Stockholm, May 16-20, IAEA-SM-303/134, pp. 379-391

87. C. B. Owens, N. P. Kirner, "Mixed Waste Management Options," Thirteenth Annual U. S. DOE Low-Level Waste Management Conference, Atlanta, November 19-21, 1991, CONF911114-Proc. 
87b. C. B. Owens, N. P. Kirner, "Mixed Waste Management Options," Waste Management 92, Volume 2, Proceedings of the Symposium on Waste Management at Tucson, Arizona, March 15,1992 , pp. $1173-1180$ (This is a revision of \#87)

171. J. Roderick, L. H. Harmon, S. Chakraborti, M. Abashian, "Transportaiton of DOE Mixed Waste in the U.S.," Proceedings of the Second International Symposium on Mixed Waste, Baltimore, Maryland, August 17-20, 1993, pp. 12.4.1-12.4.7.

77. W. A. Ross, M. R. Elmore, C. L. Warner, L. J. Wachter, W. L. Carlson, R. L. Devries, "Locations, Volumes, and Characteristics of DOE's Mixed Low-Level Wastes," Waste Management 92, Volume 2, Proceedings of the Symposium on Waste Management at Tucson, Arizona, March 1-5, 1992, pp. 1127-1135

76. C. Shapiro, "DOE Candidate Wastes for SCWO Treatment," EG\&G Idaho Engineering Design File, Project File 015581-A, EDF \#4.0, December 1, 1992

104. C. Shapiro, "Comments on document 'Evaluation of DOE Mixed Waste for SCWO Processing," Notegram to R. W. Marshall, December 29, 1992.

81. W. L. Teeter, EG\&G Rocky Flats, letter to C. Shapiro, "Waste Streams as Possible Candidates for SCWO," June 26, 1992.

158. A. J. Thompson, M. L. Goo, "Mixed Waste: A Proposed Solution That Focuses on the Underlying Problem Rather Than on its Symptoms," Proceedings of the Second International Symposium on Mixed Waste, Baltimore, Maryland, August 17-20, 1993, pp. 3.4.1-3.4.22.

88. M. N. Wells, L. L. Bailey, "Mixed Waste Disposal Facilities at the Savannah River Site," Thirteenth Annual U. S. DOE Low-Level Waste Management Conference, Atlanta, November 19-21, 1991, CONF-911114-Proc.

83. WMIS data: WMIS printouts for some mixed waste streams in SCWO literature library. WMIS printouts for others can be obtained from Wendy Carlson, 6-6928, WAC A-2; for recent updates of INEL streams see Mark Argyle, 6-9207.

\section{ALTERNATIVE PROCESSES \& SCWO COMPARATIVE STUDIES}

97. T. D. Anderson, L. D. Lyman, "Innovation Technologies for Treatment of Hazardous and Mixed Wastes," Proc. Int. Symp. on Man. of Low and Int. Level Rad. Wastes, Stockholm, May 16-20, 1988, IAEA-SM-303/93, pp. 405-415.

166. Z. Chiba, "Mediated Electrochemical Oxidation of Mixed Wastes," Proceedings of the Second International Symposium on Mixed Waste, Baltimore, Maryland, August 17-20, 1993, pp. 10.2.1-10.2.7.

169. J. J. Coogan, R. A. Tennant, L. A. Rosocha, P. J. Wantuck, "Advanced Oxidation and Reduction Processes: Closed-Loop Applications for Mixed Waste, ${ }^{n}$ Proceedings of the Second International Symposium on Mixed Waste, Baltimore, Maryland, August 17-20, 1993, pp. 10.5.1-10.5.12. 
86. W. M. Copa, W. B. Gitchel, "Wet Oxidation," Section 8.6, Standard Handbook of Hazardous Waste Treatment and Disposal, H. M. Freedman, editor, McGraw-Hill Book Co., 1988.

163. A. J. Darnell, R. L. Gay, J. D. Navratil, J. C. Newcomb, "Molten Salt Oxidation of Radioactive Hydraulic Oil Waste," Proceedings of the Second International Symposium on Mixed Waste, Baltimore, Maryland, August 17-20, 1993, pp. 7.3.1-7.3.7.

145a. J.-C. Dehmel, W. Thurber, M. Nawar, "Comparative Risk Assessment of Incineration vs. Compaction and Supercritical Water Oxidation for Low-Level and Mixed Wastes, ${ }^{\text {Fourteenth }}$ Annual U.S. DOE Low-Level Radioactive Waste Management Conference, Phoenix, Arizona, Nov. 18-20, 1992, pp.7-20.

165. K. Elsberry, P. M. Dhooge, "Treating Contaminated Organic Compounds Using the DETOX Process," Proceedings of the Second International Symposium on Mixed Waste, Baltimore, Maryland, August 17-20, 1993, pp. 10.1.1-10.1.8.

56. R. L. Gillins, E. M. Steverson, K. A Balo, "Thermal Treatment Technology Study and Data Base for DOE Mixed Waste," Waste Management '91, Vol 1, pp. 885-890.

164. D. J. Hallett, "The Eco Logic Process," Proceedings of the Second International Symposium on Mixed Waste, Baltimore, Maryland, August 17-20, 1993, pp. 7.6.1-7.6.9.

225. R. G. Hickman, MWMF Technology Review: Wet Oxidation, July 8, 1993.

A27. B. W. L. Jang, Y. He, R. B. Timmons, "Catalytic Hydrochlorination of Polychlorinated Liquid Waste," Emerging Technologies for Hazardous Waste Management, 1992 Book of Abstracts for the Special Symposium, Atlanta, I\&E Chemistry Division, ACS, Sept. 22-23, 1992, pp 98-99.

176. R. B. Kidman, K. S. Tsuji, Preliminary Cost Comparison of Advanced Oxidation Processes, LA-12221-MS, June, 1992

48. N. F. Sather, "Hazardous Waste: Where to Put It? Where Will it Go?," Mech. Eng, Sept. $1988,70-75$.

90. R. G. Shimko, A. K. Saha, "Mixed Waste Processing - A Critical Assessment of Available Technologies," Waste Management '91, Vol 1, pp. 753-759.

209. D. L. Shuck, M. C. Skriba, J. F. Wade, "Evaluating Non-Incineration Treatment of Organically Contaminated Low Level Mixed Waste," Proceedings pf the Symposium on Waste Management at Tucson, Arizona, February 28-March 4, 1993, pp. 683-690.

251. R. Tolman, Waste Treatment System and Method Utilizing Pressurized Fluid, U.S. Patent 5,280,701, Jan. 25, 1994.

161. R. W. Tyler, S. A. Anderson, T. L. Rising, "Land Disposal Restriction (LDR) Waste Management Strategy at Rocky Flats," Proceedings of the Second International Symposium on Mixed Waste, Baltimore, Maryland, August 17-20, 1993, pp. 6.2.1-6.2.20. 
162. R. S. Upadhye, J. G. Wilder, C. E. Karlsen, "Molten Salt Destruction Process for Mixed Waste," Proceedings of the Second International Symposium on Mixed Waste, Baltimore, Maryland, August 17-20, 1993, pp. 7.2.1-7.2.6.

157. S. Vijayan, L. P. Buckley, Decontamination Flowsheet Development for a Waste Oil Containing Mixed Radioactive Contaminants," Proceedings of the Second International Symposium on Mixed Waste, Baltimore, Maryland, August 17-20, 1993, pp. 2.4.1-2.4.13.

168. F. Wang, B. Lum, K. Cassidy, "Ultraviolet/Hydrogen Peroxide Process for Treating Aqueous Mixed Waste," Proceedings of the Second International Symposium on Mixed Waste, Baltimore, Maryland, August 17-20, 1993, pp. 10.4.1-10.4.8.

\section{ENVIRONMENTAL REGUI:ATIONS}

93. R. R. Boyle, D. A. Orlando, "Regulatory Aspects of Mixed Waste," Twelfth Annual U.S. DOE Low-Level Waste Management Conference, Chicago, August 28-29, 1990, CONF-9008119Proc., pp. 13-26.

145d. L. Chang, S. C. Tripp, "Requirements and Impacts of the Federal Facility Compliance Act on the Department of Energy," Fourteenth Annual U.S. Department of Energy Low-Level Radioactive Waste Management Conference, Phoenix, Arizona, Nov. 18-20, 1992, pp. 485-489.

78. McCoy and Associates, The RCRA Land Restrictions: A Guide to Compliance, 1992 edition (Note: this book has been received by the SCWO project and is currently in the hands of John Svoboda, 6-0552, MS 1500 if you wish to use it)

79. McCoy and Associates, RCRA Regulations and Keyword Index, 1992 edition (Note: this book has been received by the SCWO project and is currently in the hands of John Svoboda, 6-0552, MS 1500 if you wish to use it)

80. McCoy and Associates, 1992 Catalog of Products and Services (pertaining to RCRA, SARA, CERCLA, and CAA)

99. G. E. Reyes, "The Mixed Waste Dilemma," Waste Management 92, Volume 2, Proceedings of the Symposium on Waste Management at Tucson, Arizona, March 1-5, 1992, pp. 1157-1161.

100. M. F. Weber, D. A. Orlando, "Clearing a Path for Regulatory Compliance: An Update of NRC Mixed Waste Activities," Waste Management 92, Volume 2, Proceedings of the Symposium on Waste Management at Tucson, Arizona, March 1-5, 1992, pp. 1163-1167.

VII. NEWSLETTER ITEMS Complete text available in most cases

N1. "Environmental Group Seeks Moratorium on Incineration," Waste Treatment Tech. News, Aug, 1992 p. 1

N2. "EWT Designs SCWO Units," High Tech Sep. News 5(2), July 1992 
N3. "SRI Plans to Begin Operation Soom of an Experimental SCWO Facility, Sludge 17(5), Feb. 26, 1992

N4. "Lab.-Scale Pilot Plant Can Perform SCWO for Treatment of Haz. Waste," (SRI, 2.2 gal/hr), Waste Treatment Tech. News 7(5), March, 1992

N5. "Sandia Nat. Lab. Investigates Promise, Danger of Hydrothermal Flames Produced During SCO Waste Treatment," Waste Treatment Tech. News 6(5), March, 1991.

N6. "DARPA Wants SCWO Pilot Plant," Defense Cleanup 2(2), Feb. 1, 1991.

N7. "Sandia Pilot Detoxifies Liquid Wastes," Defense Cleanup 1(9), Nov. 23, 1990.

N8. "Sandia Nat. Lab. Researchers Investigat SCWO for Waste Treatment," High Tech Sep. News (4), Sept. 1990.

N9. "MODAR Waste Systems and Lummus Crest Agree to Jointly Commercialize SCWO Technology," Waste Treatment Tech. News 5(3), Jan. 1990.

N10. "DOE Five-Year Cleanup Plan To Focus on New Technologies," Haz. Waste News 11(15), April 10, 1989.

N11. "Mobile Process Defuses Munitions," Chem. Eng. Prog., Oct. 1992, p. 23-24.

N12. "Congress Kills Funds for Alabama Chemical Weapons Incinerator," Chem. Week, Oct. 14, 1992.

N13. "Scientist Tests Alternative for Hazwaste Disposal," World Wastes, Aug. 1992, p. 16 (SCWO in centrifuge system).

N14. "SCWO Zaps Hazardous Wastes," Chem. Eng. Prog., April, 1992 p. 20-21.

N15. "L'Air Liquide links With ABB Lummus Crest (for development of SCWO)," Chem. Marketing Reporter, June 24, 1991, p. 28. and High Tech Sep News 4(3), Aug. 1991

N16. "SCWO Destroys Aqueous Toxic Wastes," Sandia Science News, September, 1990.

N17. "The Good News is that SCWO Could Destroy Hazardous Wastes," Env. Sci \& Tech., Sept. 1990, p. 1277

N18. "Supercritical Look at Wastewater," Chem. Week, May 23, 1990, p. 8

N19. "Waste-Oxidation Technology," Chem. Week, Nov. 15, 1989, p. 60

N20. "MODAR Has Patented a SCWO Process that Destroys Hazardous Organic Waste," Plant Engineering, Oct. 14, 1982, p. 10. 
N21. "Stone and Webster Building Supercritical Wet Oxidation Pilot Plant," High Tech Sep News (1), June, 1992.

N23. "SRI Intends to Conduct SCWO under many conditions...," Haz. Waste News 14(6), Feb. 10, 1992.

N24. "Pressure Cooking Hazardous Wastes...," Energy and Environment, March, 1991.

N27. "Supercritical Fluids: Supercritical Technology to Destroy Aqueous Toxic Wastes Studied," High Tech Sep News 4(5), Oct. 1991.

N28. "SCW System Destroys 'Problem' Wastes..." Chem. Eng., Nov, 1990.

N29. "Supercritical Water Oxidation Edges Out Incineration," Chem. Eng., July, 1993

N-30. "SCWO Destroys Chemical Agents in Lab Tests, Company Reports," HazTECH News 9(12), June 16, 1994, pp. 90-91.

\section{PRETREATMENT/POSTTREATMENT}

221. C. M. Barnes, Evaluation of Pretreatment Processes for Supercritical Water Oxidation, EGGWTD-11137, January, 1994

178. C. M. Barnes, "Removal of Sulfur and Phosphorus form DOE Mixed Waste Prior to Treatment by Supercritical Water Oxidation," EG\&G Engineering Design File WTD-121217029, EDF\#ID121217/1004, September 3, 1993

203. C. M. Barnes, "Removal of Mineral Acid Precursors form Supercritical Water Oxidation Feed," EG\&G Engineering Design File WTD-121217-029, EDF\#ID121217/1005, November 0, 1993.

175. W. Brummond, J. Celeste, J. Steenhoven, "The Mixed Waste Management Facility at the Lawrence Livermore National Laboratory," Proceedings of the Second International Symposium on Mixed Waste, Baltimore, Maryland, August 17-20, 1993, pp. 15.3.1-15.3.6.

155. K. L. Gehring, "Solidification Results from a Treatability Study of Nonincinerable Low-Level Mixed Waste," Proceedings of the Second International Symposium on Mixed Waste, Baltimore, Maryland, August 17-20, 1993, pp. 1.4.1-1.4.27.

184. D. R. Haefner, "Sulfide Pre-Treatment Prior to SCWO of Wastes," EG\&G Engineering Design File WTD-121217-029, EDF\#ID121217/1001, Sept. 9, 1993

172. H. Ho, D. G. Wygmans, D. B. Chamberlain, C. Conner, J. C. Hutter, C. Srinivasan, R. A. Leonard, L. Nunez, J. Sedlet, G. F. Vanergrift, "Treatment of Aqueous Mixed Wastes Containing RCRA Metals," Proceedings of the Second International Symposium on Mixed Waste, Baltimore, Maryland, August 17-20, 1993, pp. 13.1.1-13.1.10. 
157. C. M. Jantzen, J. B. Pickett, W. G. Ramsey, "Reactive Additive Stabilization Process for Hazardous and Mixed Waste Vitrification," Proceedings of the Second International Symposium on Mixed Waste, Baltimore, Maryland, August 17-20, 1993, pp. 4.2.1-4.2.13.

173. D. L. Lamberd, "Design of the Waste Receiving and Processing Module 2A Facility," Proceedings of the Second International Symposium on Mixed Waste, Baltimore, Manyland, August 17-20, 1993, pp. 15.1.1-15.1.8.

186. G. Loomis, D. Osborne, M. Ancho, Executive Summary of the Cryofracture Demostration Program, EG\&G-WTD-9916, September, 1991.

174. G. W. Lussiez, S. J. Zygmunt, "Hazardous Waste Treatment Facility and Skid-Mounted Treatment Systems at Los Alamos," Proceedings of the Second International Symposium on Mixed Waste, Baltimore, Maryland, August 17-20, 1993, pp. 15.2.1-15.2.10.

217. R. W. Marshall, Jr., Initial Cryofracture Study of Polyvinyl Chloride and Several Other Plastics, Supercritical Water Oxidation Technology Development File TD121217/1015, December 16, 1993. 


\section{Update to Supercritical Water Oxidation Literature Search}

September 11, 1994

\section{SCWO DESIGN, EQUIPMENT, PROCESS STUDIES, TESTING, PATENTS}

1. D. Kodra, V. Balakotaiah, "Autothermal Oxidation of Dilute Aqueous Wastes Under Supercritical Conditions," Ind. \& Eng. Chem. Res. 33(3), (1994) pp. 575-580.

2. D. C. Elliott, L. J. Sealock, E. G. Baker, "Chemical Processing in High-Pressure Aqueous Environments, Part 3, Batch Reactor Experiments for Organic Destruction, Ind. \& Eng. Chem. Res. 33(3) (1994) pp. 558-565.

3. M. Krajnc, J. Levec, "Catalytic Oxidation of Toxic Organics in Supercritical Water," Appl. Catalysis B - Environmental 3(2-3), (1994) pp. L101-L107.

4. L. L. Li, "Feedstream Preheating Effect on Supercritical Water Oxidation of Dissolved Organics," Eng. \& Fuels 8(5) (1994), pp. 1126-1130.

5. E. G. Hauptmann, S. A. Gairns, M. Modell, "Strategies for Treating Mixtures of Bleach Plant Effluents and Waste Water Sludges by Supercritical Water Oxidation," Proceedings of the 80th Annual Meeting of Canadian Pulp and Paper Association, Montreal, pp. B71-B77.

6. P. Chastagner, "Containment System for Supercritical Water Oxidation Reactor," U.S. Patent 5,326,540, July 5, 1994.

7. R. L. Farrow, G. A. Fisk, C. M. Hartwig, R. H. Hurt, J. T. Ringland, W. A. Swansiger, Technical Resource Document for Assured Thermal Processing of Wastes, SAND-94-8240, June, 1994.

8. L. T. Boock, C. Lamarca, M. T. Klein, "Hydrolysis and Oxidation in Supercritical Water," Endeavour 17(4), (1993) pp. 180-185.

9. T. Adschiri, S. Hirose, R. Malaluan, K. Arai, "Noncatalytic Conversion of Cellulose in Supercritical and Subcritical Water," J. of Chem. Eng. of Japan 26(6), pp. 676-680.

10. J. E. Sawicki, B. Casas, "Wet Oxidation System - Process Concept to Design," Environmental Progress 12(4) (1993) pp. 275-283.

11. L. T. Boock, M. T. Klein, "Lumping Strategy for Modeling the Oxidation of $\mathrm{C}_{1}-\mathrm{C}_{3}$ Alcohols and Acetic Acid in High-Temperature Water," Ind. \& Eng. Chem. Res. 32(11), (1993) pp. 2464-2473.

12. T. Hirth, E. U. Franck, "Oxidation and Hydrothermolysis of Hydrocarbons in Supercritical Water at High Pressures," Int. J. Phys. Chem. 97(9), (1993) pp. 1091-1098.

13. L. J. Sealock, D. C. Elliott, E. G. Baker, R. S. Butner, "Chemical Processing in High-Pressure Aqueous Environments, Part 1, Historical Perspective and Continuing Developments, Ind. \& Eng. Chem. Res. 32(8) (1993) pp. 1535-1541. 
14. L. X. Li, E. F. Gloyna, J. E. Sawicki, "Treatability of DNT Process Waste-Water by Supercritical Water Oxidation, Water Environment Research 65(3) (1993), pp. 250-257.

15. F. O. Azzam, S. G. Lee, "Selective Oxidation of Hydrocarbons by Supercritical Wet Oxidation," ACS Symposium Series Vol. 523 (1993) pp. 438-446.

16. W. M. Copa, R. W. Lehmann, "Two-Stage Subcriticle-Supercritical Wet Oxidation," U. S. Patent 5,240,619, Aug. 31, 1993

17. F. O. Azzam, "Application of Supercritical Wet Oxidation for the Complete and Partial Destruction of Chemical Process Waste," U. of Akron Thesis, 1993.

18. Y. Tian, T. Chen, J. Xu, Y. Luo, "Heat Transfer Characteristics of Supercritical Water Flowing in Inclined Tubes," Huagong Xuebao 44(1) 1993 pp. 34-40.

19. J. E. Sawicki, B. Casas, C. Y. Huang, W. R. Killilea, G. T. Hong, "Wet Oxidation of Aqueous Streams," U.S Patent 5,250,193, Oct. 5, 1993.

20. N. Dahmen, "Proceedings of the International Workshop on Supercritical Water and Fluid Chemistry - Waste Treatment and Future Chemical Processes," KFK-Nachr. 25(2) (1993) pp. 109-114.

21. G. Brunner, "Wastewater Treatment by Supercritical Water," Chem. Ind. 116(9), (1993) pp. 34 37.

22. M. A. Maerk, R. Buettiker, J. Voigt, "Reactor for Wet Oxidation," Swiss Patent CH 681,359, March 15, 1993.

23. L. Li, E. F. Gloyna, "High Temperature Wet Oxidation Using Sintered Separators," PCT International Patent WO 9,302,969, Feb. 18, 1993.

24. K. Nowak, G. Brunner, "Extraction and Degradation of Organic Contaminants with Supercritical Water for Soil Decontamination," Chemie Ingenieur Technik 64(2), 1992 pp. 188-189.

25. E. Sorensen, A. B. Bjerre, "Combined Wet Oxidation and Alkaline Hydrolysis of Polyvinylchloride," Waste Management 12(4), 1992, pp. 349-354.

26. J. T. Carter, J. A. Gentilucci, "Supercritical Water Oxidation Technology for DWPF," WSRC-RP92-252, Feb. 7, 1992.

27. M. R. Blank, "Destruction of Chemical Agent Simulants in Supercritical Water Oxidation," Air Force Inst. of Tech., Wright-Patterson AFB, Masters Thesis, July 1992, AD-A-258206/2/XAB.

28. C. K. Rofer, S. J. Beulow, R. B. Dyer, J. D. Wander, "COnversion of Hazardous Materials using Supercrtitical Water Oxidation," U. S. Patent 5,133,877, July 28, 1992.

29. R. E. Rossi, "Identification of Significant Process Variables for a Flow-Through Supercritical Water Oxidation Reactor," DOE/OR/00033-T485, May, 1992. 
30. H. L. La Roche, M. Weber, B. Zehnder, "Waste Water Desalination by Supercritical Water Oxidation," European Patent 612,697, Aug. 31, 1994.

31. H. E. Barner, G. T. Hong, C. Huang, W. R. Killilea, "Supercritical Water Oxidation System for Mixed Wastes, with Quenching of Overhead Effluent to Reduce Build Up of Solids in Reactor," U. S. Patent 5,200,093, April 4, 1993.

32. S. U. Hossain, C. A. Blaney, "Removal of Polychlorinated Dibenzodioxides and Dibenzofurans by Supercritical Water Oxidation," U.S. Patent 5,075,017, Dec. 24, 1991.

33. H.-H. Schwarz, D. E. Moers, "Process for the Oxidation of Water-Insoluable Organics," U. S. Patent 5,174,985, Dec. 29, 1992.

\section{CORROSION}

34. C. Liu, D. D. McDonald, E. Medina, J. J. Villa, J. M. Bueno, "Probing Corrosion Activity in High Subcritical and Supercritical Water Through Electrochemical Noise Analysis," Corrosion 50(9) (1994) pp. 687-694.

35. "Corrosion in SCWO Systems" Waste Treatment Technology News 9, Sept, 1994.

36. T. Carlson, S. Huang, K. Daehling, C. Wai, P. Taylor, A. Propp, "Corrosion of Iron Alloys in Subcritical and Supercritical Water, Proceedings 1991 Symposium on Chemistry in High-Temperature Aqueous Solutions, Provo, Utah, August 19-22, 1991, EPRI-TR-102706, August, 1993.

37. M. A. Clark, D. A. Beula, "Corrosion Control for Wet Oxidation System," European Patent Appl. EP 534,650, March 31, 1993.

\section{SUPERCRITICAL WATER CHEMISTRY AND PROPERTIES}

38. A. A. Chialvo, P. T. Cummings, "Hydrogen Bonding in Supercritical Water," J. Chem. Phys. $101(15)$ (1994) pp. 4466-4469.

39. T. Xiang, K. P. Johnson, "Acid-Base Behavior of Organic Compounds in Supercritical Water," J. of Phys. Chem. 98(32) (1994) pp. 7915-7922.

40. E. Wasserman, B. Wood, J. Brodholt, "Molecular Dynamics Study of the Dielectric Constant of Water under High Pressure and Temperature Conditions," Int. J. of Phys. Chem. 98(7), (1994) pp. 906-911.

41. E. S. Fois, M. Sprik, M. Parrinello, "Properties of Supercritical Water - An Ab-Initio Simulation," Chem. Phys. Letters 223(5-6), (1994) pp. 411-415.

42. J. L. Gao, "Simulation of the $\mathrm{Na}^{+} \mathrm{Cl}^{-}$Ion Pair in Supercritical Water," J. of Phys. Chem. 98(24) (1994), pp. 6049-6053. 
43. J. M. Seminario, M. C. Concha, J. S. Murray, P. Politzer, "Theoretical Analysis of $\mathrm{O}_{2} / \mathrm{H}_{2} \mathrm{O}$ Systems Under Normal and Supercritical Conditions," Chem. Phys Letters 222(1-2) (1994) pp. 25-32.

44. P. B. Balbuena, K. P Johnson, R. J. Rossky, "Molecular Simulation of a Chemical Reaction in Supercritical Water," J. Am. Chem. Soc. 116(6) (1994) pp. 2689-2690.

45. T. Makita, "Properties of High Pressure Fluids and Their Engineering Applications, Koatsu Gasu, March 1, 1994, pp. 34-45.

46. P. Psotorino, R. H. Tromp, M. A. Ricca, A. K. Soper, G. W. Neilson, "The Interatomic Structure of Water at Supercritical Temperatures," Nature 366, (1993) pp. 668-670.

47. A. G. Kalinichev, "Molecular Dynamics and Self-Diffusion in Supercritical Water," Int. J. Phys. Chem. 97(7) (1993), pp. 872-876.

48. J. L. Gao, "Supercritical Hydration of Organic Compounds - The Potential of Mean Force for Benzene Dimer in Supercritical Water," J. Am. Chem. Soc. 115(15), (1993) pp. 6893-6895.

49. P. Politzer, J. S. Murray, M. C. Concha, T. Brinck, "Some Proposed Criteria for Simulants in Supercritical Systems," Theoret. J. of Molec. Structure 100(2-3), (1993) pp. 107-111.

50. F. J. Armellini, J. W. Tester, "Solubility of Sodium Chloride and Sulfate in Subcritical and Supercritical Water Vapor from $450-550^{\circ} \mathrm{C}$ and 100-250 Bar," Fluid Phase Equilibria 84, (1993) pp. 123-142.

51. C. Yokoyama, A. Iwabuchi, S. Takahashi, K. Takeuchi, "Solubility of PbO in Supercritical Water," Fluid Phase Equilibria 82 (1993), pp. 323-331.

52. J. S. Gallagher, R. Crovetto, J. M. H. L. Sengers, "The Thermodynamic Behavior of the $\mathrm{CO}_{2}-$ $\mathrm{H}_{2} \mathrm{O}$ System from $400 \mathrm{~K}$ to $1000 \mathrm{~K}$, up to $100 \mathrm{MPa}$ and $30 \%$ Mole Fraction of $\mathrm{CO}_{2},{ }^{n}$ ACS Symposium Series Vol. 523, (1993) pp. 438-446.

53. J. M. Simonson, H. D. Cochran, R. E. Mesmer, P. T. Cummings, S. Karaborni, "Simulation of Supercritical Water and Supercritical Water Solutions," Proceedings 1991 Symposium on Chemistry in High-Temperature Aqueous Solutions, Provo, Utah, August 19-22, 1991, EPRI-TR-102706, August, 1993.

54. S. Hetteiaachchi, H. Song, R. Emerson, D. D. McDonald, "Measurement of $\mathrm{pH}$ and Potential in Supercritical Water," EPRI-TR-102277, Vol. 1, April, 1993.

55. J. V. Walther, A. B. Woodland, "Experimental Determination and Interpretation of the Solubility of the Assemblage Microcline, Muscovite and Quartz in Supercritical Water," Geochim. Cosmochim. Acta 57(11), (1993) pp. 2431-2437.

56. H. D. Cochran, P. T. Cummings, S. Karaborni, "Solvation in Supercritical Water," Fluid Phase . Equilibrium 71(1-2), 1992, pp. 1-16. 
57. A. G. Kalinichev, K Heinzinger, "Computer Simulations of Aqueous Fluids at High Temperatures and Pressures," Thermodynamic Data: Systematics and Estimation, S. K Saxena, editor, Springer-Verlag, N. Y., 1992, pp. 1-59.

58. Y. Tanaka, "Mysterious Fine Particles Formed During the Rapid Expansion of Supercritical Water Solutions," Koatsuryoku no Dagaku to Gijutsu 1, 1992, pp. 263-271.

59. A G. Kalinichev, "Self-Diffusion in Compressed Supercritical Water: A Molecular Dynamics Study," Recent Trends High Pressure Res., Proc. 13th AIRAPT Int. Conf. High Pressure Sci. Technol., 1992.

\section{KINETICS AND REACTION MECHANISMS}

60. A. R. Katritzky, R. A. Barcock, M. Siskin, W. N. Olmstead, "Aqueous High-Temperature Chemistry of Carbocycles and Heterocycles, Part 23, Reactions of Pyridine Analogs and Benzopyrroles in Supercritical Water at $460^{\circ}$ C, Energy \& Fuels 8(4), pp. 990-1001.

61. B. Kuhlmann, E. M. Arnett, M. Siskin, "Classical Organic Reactions in Supercritical Water," J. Org. Chem 59(11), (1994) pp. 3098-3101.

62. A. R. Katritzky, R. A. Barcock, M. Balasubramanian, J. V. Greenhell, M. Siskin, W. N. Olmstead, "Aqueous High-Temperature Chemistry of Carbocycles and Heterocycles, Part 21, Reactions of Sulfur Containing Compounds in Supercritical Water at $460^{\circ} \mathrm{C}$," Energy \& Fuels 8(2), pp. 498-506.

63. A. R. Katritzky, R. A. Barcock, M. Balasubramanian, J. V. Greenhell, M. Siskin, W. N. Olmstead, "Aqueous High-Temperature Chemistry of Carbocycles and Heterocycles, Part 21, Reactions of Some Benzenoid Hydrocarbons and Oxygen-Containing Derivatives in Supercritical Water at $460^{\circ} \mathrm{C}$, ${ }^{\prime}$ Energy \& Fuels 8(2), pp. 487-497.

64. T. B. Brill, M. L. Kieke, J. W. Schoppelrei, "Chemical Reactions in Very Hot Water," 207th Spring National Meeting of the American Chemical Society, San Diego, March 13-18, 1994, Paper INOR 265, p. 857

65. M. J. Cocero, R. Gonzalez, F. Fernandez-Polanco, "Supercritical Water Oxidation - Application to Reduce Industrial Wastes," Ingenieria Quimica 297, (1994) pp. 83-89.

66. N. Crain, S. Tebbal, L. X. Li, E. F. Gloyna, "Kinetics and Reaction Pathways of Pyridine Oxidation in Supercritical Water," Ind. \& Eng. Chem. Res. 32(10) (1993) pp. 2250-2268.

67. M. P. Kasi, F. O. Azzam, S. G. Lee, "Coal Agloflotation and Supercritical Wet Oxidation - Novel Remediation Techniques for Ultra-Cleaning of Contaminated Soils," J. of Haz. Mater. 35(1), pp. 17-30.

68. K. C. Chang, L. X. Li, E. F. Gloyna, "Supercritical Water Oxidation of Acetic Acid by Potassium Permanganate," J. Haz. Mater. 33(1), (1993) pp. 51-62. 
69. T. J. Houser, Y. Zhou, C. C. Tsao, X. Liu, "Removal of Heteroatoms from Organic Compounds by Supercritical Water," ACS Symposium Series 514 (1993) pp. 327-337.

70. C. F. Melius, "Solvent Effects on the Chemical Reaction Mechanisms of Hazardous Waste Removal," American Chemical Society National Meeting, Chicago, August 22-27, 1993.

71. M. D. Turner, "Supercritical Water Oxidation of Dimethyl Methylphosponate and Thiodiglycol," U. of Texas Thesis, 1993.

72. L. T. Boock, "A Quantitative Analysis of Reactions in Supercritical Water: Experimental Kinetics and Mechanistic Modeling," U. of Delaware Thesis, 1993.

73. A. A. Clifford, "Reactions in Supercritical Water," Chim. Oggi. 11(10), pp. 36-37.

74. R. K. Li, T. D. Thornton, P. E. Savage, "Kinetics of $\mathrm{CO}_{2}$ Formation from the Oxidation of Phenols in Supercritical Water," Env. Sci. \& Tech. 26(12), (1992) pp. 2388-2395.

\section{NEWSLETTERS AND NEWS ITEMS}

75. "GA Successfully Demonstrates SCWO for Eliminating Chemical Weapons," Env. Sci. \& Tech., Aug. 1994, p. 356

76. "Organo (Japan) gets exclusive rights to hazardous \& hard-to-decompose waste technology from Modar Waste Systems," Japan Chemical Week, June 9, 1994, p. 8.

77. "Waste Treatment: Maturing Market Stimulates New Cleanup Technologies," Chemical Week, June 15, 1994, p. 16.

78. "Supercritical Water Oxidation Process Recycles Most Plastics," Nikkan Kogyo Shimbun April 19, 1994, p. 11.

79. "Chemical Weapons Cleanup: Supercritical Water Oxidation Proven Chemical Agent Destruction Method," Env. Rem. Tech. 2(13), June 29, 1993.

80. "Waste Destruction Using Supercritical Water Oxidation," Env. Problems and Remediation 94(7), July 1994.

81. "SCWO Chem Demil Issue Dropped," Defense Cleanup 5, August 19, 1994.

82. "Supercritical Water Topic at Strasbourg," Water Technology News 2(5), Aug. 1994. (Describes 10 papers on SCWO to be presented at 3rd Int. Conf on SC Fluids, Oct. 17-19, 1994

83. "Army Will Pursue New Options for Chemical Agent Destruction," Report on Defense Plant Wastes 6(9), April 25, 1994.

84. "Process for Destruction of Hazardous Waste Materials," Equip. \& Mater. Update 94(8), Aug. 1994. (Describes Los Alamos SCWO patent application) 
85. "New Technology: New Use for Water in Cleaning Up," Water Technology News 2(4), July, 1994.

86. "Supercritical Water System Goes Commercial," Environment Business, Feb. 23, 1994. (Modar/GNI Group demo plant).

87. "Supercritical Water Oxidation: First Place in Race to Commercialize," Waste Treatment Technology News 9(9), June, 1994. (ECO Waste-Huntsman plant)

88. "MODEC: Not and Identity Crisis," Waste Treatment Technology News 9(9), June, 1994.

89. "Estimated Year for Alternative Disposal Technologies to Reach Full-Rate Operations, Defense Cleanup 5(7), April 29, 1994.

90. "Army wants to burn chemical munitions now," Defense Cleanup 5(15), April 15, 1994.

91. "MIT Takes on Military Wastes," High Tech Separations News 6(11), April, 1994.

92. "Wastewater Requires Additional Fuel, High Tech Separations News 6(11), April, 1994.

93. "Incineration Takes Heat From Enviros," Defense Cleanup 5(12), March 25, 1994. (contains endorsment of SCWO and other technologies by environmentalists)

94. "Improving Viability of Water Oxidation," High Tech Separations News 6(10), March, 1994.

95. "First Commercial Waste Treatment," High Tech Separations News 6(10), March, 1994. (Modar/GNI Group plant)

96. "Supercritical Water Oxidation for Treating Hazardous Wastes," Ind. Health \& Haz. Update 94(3), March, 1994. (Review of MIT MS thesis)

97. "Supercritical Water Treats Chlorinated Organics," Waste Treatment Technology News 9(4), Jan, 1994. (GNI Group/Modar plant)

98. "Water Depolymerizes Polyvinyl Chloride," High Tech Separations News 6(8), Jan, 1994.

99. "Noncatalytic Incineration of Transformer Fluid in Supercritical Water," High Tech Separations News 6(6), Dec, 1993.

100. "Waste Water Stream from Coal Desulfurization Purified via Supercritical Wet Oxidation," High Tech Separations News 6(6), Nov, 1993.

101. "Supercritical Wet Oxidation Suited to Remediation of Contaminated Soil," High Tech Separations News 6(6), Nov, 1993.

102. "Zimpro Passavant Puts Together Two-Stage Subcritical/Supercritical Wet Oxidation," Waste Treatment Technology News 8(1), October, 1993. 
103. "Eco Waste Technologies Commercializes Supercritical Water Oxidation," High Tech Separations News 6(4), Sept, 1993.

104. "More Investigations into the Chemistry of Supercritical Water Oxidation Processes," High Tech Separations News 6(4), Sept, 1993.

105. "NRC Panel Identifies Possible Substitutes for Incineration," Report on Defense Plant Wastes 5(13), June 21, 1993.

106. "Operation and Safety of a Supercritical Wet Oxidation Pilot Plant," High Tech Separations News 5(12), May, 1993.

107. "NIST and Conoco Study New Waste Disposal Technique using Near-Supercritical Water," High Tech Separations News 5(10), March, 1993.

108. "Calling for an End to Incineration," Chemical Week, March 4, 1992, p. 19. (endorsement of SCWO and other technologies by National Toxics Campaign Fund). 


\section{Appendix B}

Engineering Design File 10121217//032 

Project File Number

Funct0ional File Number

\section{ENGINEERING DESIGN FILE}

$\begin{array}{ll}\text { Project/Task } & \text { Supercritical Water Oxidation } \\ \text { Subtask } & \text { R\&D/Corrosion Test }\end{array}$

EDF 1 of 12
Page

\section{TITLE: Effluent Analysis of MODAR Corrosion Test}

\section{SUMMARY}

The summary briefly defines the problem or activity to be addressed in the EDF, gives a summary of the activities performed in addressing the problem and states the conclusions, recommendations, or results arrived at from this task.

REVISION 1 OF THIS EDF. REMOVE ORIGINAL VERSION FROM YOUR FILES.

The feed and effluent analysis of the three MODAR tests are used to determine the location and mass balance for the cerium, zinc, and lead surrogates. Conclusions are based on the data from the 120 hour run because the data is more complete for that run.

Distribution (complete package): C.M. Barnes, J.M. Beller, T.R. Charlton, K.M. Garcia, C. Shapiro

Distribution (summary page only): farley Warren MS 3770

\begin{tabular}{|c|c|c|c|c|c|}
\hline $\begin{array}{l}\text { Author } \\
\text { K. M. Garcia }\end{array}$ & $\begin{array}{l}\text { Dept. } \\
4130\end{array}$ & $\begin{array}{l}\text { Reviewed } \\
\text { C. M. Barnes }\end{array}$ & $\begin{array}{l}\text { Date } \\
1-6-95\end{array}$ & $\begin{array}{l}\text { Approved } \\
\text { J. M. Beller }\end{array}$ & $\begin{array}{l}\text { Date } \\
|f| c \mid-j)\end{array}$ \\
\hline teiser & & $O M B$ & & & \\
\hline
\end{tabular}


Lockheed Idaho Technologies Co

FORM EGG-2631\#

(Rev. 01-92)

This first run was for 3 hours:

Run 937

Feed:

20 liters of $\mathrm{H}_{2} \mathrm{O}=20,000$ grams

108 grams of $\mathrm{CeCl}_{3}, 57$ grams of $\mathrm{ZnSO}_{4}, 45$ grams $\mathrm{PbCl}_{2}$

$5400 \mathrm{ppm} \mathrm{CeCl}_{3}, 2850 \mathrm{ppm} \mathrm{ZnSO}_{4}, 2250 \mathrm{ppm} \mathrm{PbCl}_{2}$ and TrimSol

Water/Metals Solution $-60 \mathrm{cc} / \mathrm{min} \times(3 \times 60 \mathrm{~min})=10.8$ liters

1) Cerium calculation

Cerium 140.12

Chloride 35.453

$\mathrm{CeCl}_{3} 140.12+(35.453 \times 3)=246.479$

Cerium $140.12 / 246.479=.5679$

$.5679 \times 5400 \mathrm{ppm}=3067 \mathrm{ppm}$ cerium $=(.003 \times 10800)=33.12$ grams of cerium

Lab Analysis: $1800 \mathrm{ppm}$ of cerium in the metals feed

$.0018 \times 10800=19.44$ grams of cerium

2) Zinc Calculation

Zinc 65.37

Sulfur 32.064

Oxygen 16

$\mathrm{ZnSO}_{4}(4 \mathrm{x} 16)+(32.064)+65.37=161.434$

$65.37 / 161.434=.4049$

$.4049 \times 2850 \mathrm{ppm}=1154 \mathrm{ppm}$ of zinc $=(.0011 \times 10800)=12.46$ grams of zinc

Lab Analysis: $830 \mathrm{ppm}$ of zinc

$.00083 \times 10800=8.96$ grams of zinc

3) Lead Calculation

Lead 207.19

Chlorine 35.453

$\mathrm{PbCl}_{2} 207.19+(35.454 \times 2)=278.1$

$207.19 / 278.1=.745$

$.745 \times 2250=1676.31 \mathrm{ppm} \mathrm{lead}=(00167 \times 10800)=18.1$ grams of lead

Lab Analysis: $33 \mathrm{ppm}$ of lead

$3.3 \times 10^{-5} \times 10800=.3564$ grams of lead 
Lockheed Idaho Technologies Co

FORM EGG-2631\#

(Rev. 01-92)

4) Chlorine Calculation

TrimSol $\left(30 \% \mathrm{C}_{20} \mathrm{H}_{37} \mathrm{Cl}_{5}\right)$

$30 \mathrm{cc} / \mathrm{min} \times(4.6 \mathrm{hrs} \times 60 \mathrm{~min})=8.28$ liters of TrimSol

Carbon 12

Hydrogen 1

Chlorine 35.453

$\left(\mathrm{C}_{20} \mathrm{H}_{37} \mathrm{Cl}_{5}\right)=(12 \times 20)+37+(35.453 \times 5)=454.265$

Chlorine 177.265/454.265 = .39

$.39 \times .3=11.77 \% \quad(.1177 \times 8280)=968.8$ grams of chlorine

$\mathrm{CeCl}_{3} 140.12+(35.453 \times 3)=246.479$

chlorine $106.36 / 246.48=.43$

$.43 \times 5400 \mathrm{ppm}=2330 \mathrm{ppm}=(.00233 \times 10800)=25.16$ grams of chlorine

$\mathrm{ZnSO}_{4}(4 \times 16)+(32.064)+65.37=161.434$

$\mathrm{PbCl}_{2} 207.19+(35.454 \times 2)=278.1$

chlorine $70.91 / 278.1=.255$

$.255 \times 2250=573.69 \mathrm{ppm} \quad(.00057369 \times 10800)=6.2$ grams of chlorine

Effluent: $1250 \mathrm{cc} / \mathrm{min} \times(4.6 \mathrm{hrs} \times 60 \mathrm{~min})=345$ liters

Liquid Effluent - Chloride 2600 ppm, Sulfate $170 \mathrm{ppm}$, Chromium $4.8 \mathrm{ppm}$, Iron .4ppm, lead $.16 \mathrm{ppm}$, moly $3.4 \mathrm{ppm}$, nickel $15.8 \mathrm{ppm}$, potassium $16 \mathrm{ppm}$, Sodium $2100 \mathrm{ppm}$, zinc 5.5 ppm

Chloride: $(.0026 \times 345,000)=897$ grams of chlorine

Zinc $\left(5.5 \times \mathrm{xE}^{-6} \times 345,000\right)=2$ grams of zinc

Sodium $(.0021 \times 345,000)=724.5$ grams of sodium

Lead $\left(1.6 \mathrm{E}^{-7} \times 345,000\right)=0.06$ grams of lead

\begin{tabular}{|c|c|c|}
\hline Solid : Bottom 1 gram & Solid: Top 2 grams & $\begin{array}{l}\text { Solid : 937-11.063 } \\
\text { grams }\end{array}$ \\
\hline Sodium $300,000 \mathrm{ppm}$ & Sodium $9,700 \mathrm{ppm}$ & Sodium $3500 \mathrm{ppm}$ \\
\hline Chloride ND & Chloride $\quad 6,600 \mathrm{ppm}$ & Chloride Unknown \\
\hline Nickel $\quad 110,000 \mathrm{ppm}$ & (.0132 grams) & Nickel 74000 ppm \\
\hline (.11 grams) & Nickel $\quad 500,000 \mathrm{ppm}$ & (.0047 grams) \\
\hline Cerium $\quad 3,700 \mathrm{ppm}$ & $\begin{array}{l}\text { (1 gram) } \\
\text { Cerium }\end{array}$ & Cerium $300000 \mathrm{ppm}$ \\
\hline $\begin{array}{l}.0031 \text { grams }) \\
\text { Zinc } 8,200 \mathrm{ppm}\end{array}$ & (.0116 grams) & $\begin{array}{l}.019 \text { grams }) \\
\text { Zinc } 5200 \mathrm{ppm}\end{array}$ \\
\hline (.0082 grams) & $4,600 \mathrm{ppm}$ & ( .0003 grams $)$ \\
\hline $\begin{array}{l}\text { Lead } \\
(.00018 \text { grams })\end{array}$ & $\begin{array}{ll}\text { (.0092 grams }) & \\
\text { Lead } & 320 \mathrm{ppm} \\
(.00064 \text { grams }) & \end{array}$ & $\begin{array}{l}\text { Lead } 1200 \mathrm{ppm} \\
\text { ( } .000076 \text { grams })\end{array}$ \\
\hline
\end{tabular}


Lockheed Idaho Technologies Co

FORM EGG-2631\#

(Rev. 01-92)

Chlorine $897 /(969+25+6)=89.7 \%$

Cerium $\quad .034$ grams $\quad .034 / 19.4=0.2 \%$

Zinc $\quad 2.018$ grams $\quad 2.02 / 8.96=8.3 \%$

Lead $\quad .061$ grams $\quad .061 / .3564=17.1 \%$

Run 937 OBSERVATIONS: A 90\% chlorine mass balance is achieved in the liquid effluent. Sodium present in the bottom solids could be from bicarbonate. The cerium does not appear to be coming completely through the reactor while most of the lead remained in the feed tank. The cerium is not soluble but is settling out or depositing on the walls.

Lead Sulfate precipitated from the Run 937 feed mixture leaving an estimated content of the lead in the feed of $30 \mathrm{ppm}$. This is less than $2 \%$ of the lead added.

This run is for 56.5 hours

Run 938

Feed:

Zinc chloride has been used instead of zinc sulfate to prevent the lead from precipitating out of the feed mixture.

20 liters of $\mathrm{H}_{2} \mathrm{O}=20,000$ grams

108 grams of $\mathrm{CeCl}_{3}, 44$ grams of $\mathrm{ZnCl}_{2}, 45$ grams $\mathrm{PbCl}_{2}$

$5400 \mathrm{ppm} \mathrm{CeCl}_{3}, 2200 \mathrm{ppm} \mathrm{ZnCl}_{2}, 2250 \mathrm{ppm} \mathrm{PbCl}_{2}$ and $13 \mathrm{wt} \%$ of TrimSol

Water/Metals Solution $-60 \mathrm{cc} / \mathrm{min} \times(56.5 \times 60 \mathrm{~min})=203.4$ liters

1) Cerium calculation

Cerium 140.12

Chloride 35.453

$\mathrm{CeCl}_{3} 140.12+(35.453 \times 3)=246.479$

Cerium $140.12 / 246.479=.5679$

$.5679 \times 5400 \mathrm{ppm}=3067 \mathrm{ppm}$ cerium $=(.003067 \times 203400)=623.8$ grams of cerium

2) Zinc Calculation

Zinc 65.37

Chlorine 35.454

$\mathrm{ZCl}_{2}(65.37)+(35.454 \times 2)=136.28$

$65.37 / 136.28=.48$

$.48 \times 2850 \mathrm{ppm}=1.368 \mathrm{ppm}$ of zinc $=(.0014 \times 203400)=278.25$ grams of zinc

3) Lead Calculation

Lead 207.19

Chlorine 35.453

$\mathrm{PbCl}_{2} 207.19+(35.454 \times 2)=278.1$

$207.19 / 278.1=.745$

$.745 \times 2250=1676.31 \mathrm{ppm}$ lead $=(00167 \times 203400)=341.0$ grams of lead

4) Chloride Calculation (not including surrogates) 
Lockheed Idaho Technologies Co

FORM EGG-2631\#

(Rev. 01-92)

$30 \mathrm{cc} / \mathrm{min} \times 55.5 \mathrm{hrs} \times 60 \mathrm{~min} / \mathrm{hr}=99,900$ milliliters

$11.77 \%$ × 99,900 milliliters $=11,688 \mathrm{~g}$ of chlorides

Effluent:

\begin{tabular}{|c|c|c|}
\hline $938-16$ grams & $938-2 \quad 17.8$ grams & $938-3 \quad 4.5$ grams \\
\hline $\begin{array}{l}\text { Sodium } 2000 \mathrm{ppm} \\
(.012 \text { grams }) \\
\text { Chloride ND } \\
\text { Nickel } 48000 \mathrm{ppm} \\
(.288 \text { grams }) \\
\text { Cerium } 98000 \mathrm{ppm} \\
(.588 \text { grams }) \\
\text { Lead } 8200 \mathrm{ppm} \\
(.05 \text { grams }) \\
\text { Zinc } 64000 \mathrm{ppm} \\
(.38 \text { grams) }\end{array}$ & 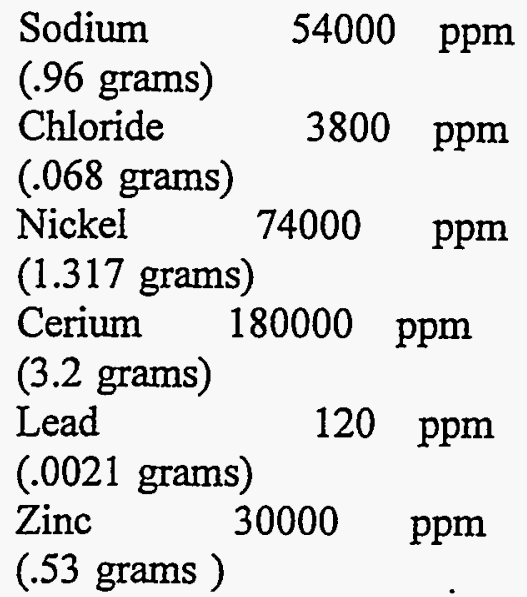 & 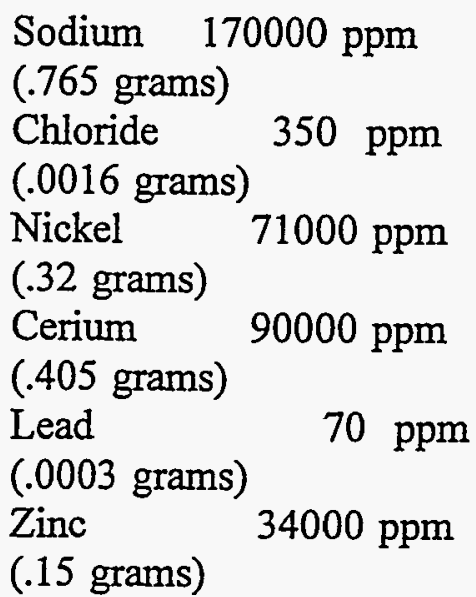 \\
\hline
\end{tabular}

Liquid Effluent $(1250 \mathrm{cc} / \mathrm{min} \times 56.5 \times 60 \mathrm{~min})=4,237.5$ liters

Chloride $2500 \mathrm{ppm}$, Sulfate $190 \mathrm{ppm}$, Chromium $2.7 \mathrm{ppm}$, Iron $.3 \mathrm{ppm}$, lead $.4 \mathrm{ppm}$, moly $2.3 \mathrm{ppm}$, nickel $3.9 \mathrm{ppm}$, potassium $53 \mathrm{ppm}$, sodium $3000 \mathrm{ppm}$, zinc $9.6 \mathrm{ppm}$

Chloride : $(.0025 \times 4237500)=10,593.75$ grams

Zinc: $9.6 \mathrm{E}^{-6}$ x $4237500=40.68+1.06=41.74$ grams $41.74 / 234.7=17.8 \%$

Lead $1.695+.0524=1.747$ grams $\quad 1.747 / 341.0=.51 \%$

Cerium 4.193 grams $4.193 / 623.8=.67 \%$ 
Lockheed Idaho Technologies Co

FORM EGG-2631\#

(Rev. 01-92)

\section{Run 939-940}

This run is for 59.6 hours

Feed:

Water/Metals Solution $-60 \mathrm{cc} / \mathrm{min} \times(59.6 \mathrm{hrs} \times 60 \mathrm{~min})=214.56$ liters

1) Cerium calculation

Cerium 140.12

Chloride 35.453

$\mathrm{CeCl}_{3} 140.12+(35.453 \times 3)=246.479$

Cerium $140.12 / 246.479=.5679$

$.5679 \times 5400 \mathrm{ppm}=3067 \mathrm{ppm}$ cerium $=(.003 \times 214560)=643.68$ grams of cerium

2) Zinc Calculation

Zinc 65.37

Chlorine 35.454

$\mathrm{ZCl}_{2}(65.37)+(35.454 \times 2)=136.28$

$65.37 / 136.28=.48$

$.48 \times 2850 \mathrm{ppm}=1368 \mathrm{ppm}$ of zinc $=(.0014 \times 214560)=293.52$ grams of zinc

3) Lead Calculation

Lead 207.19

Chlorine 35.453

$\mathrm{PbCl}_{2} 207.19+(35.454 \times 2)=278.1$

$207.19 / 278.1=.745$

$.745 \times 2250=1676.31 \mathrm{ppm}$ lead $=(00167 \times 214560)=358.32$ grams of lead

4) Chloride Calculation (not including surrogates)

$30 \mathrm{cc} / \mathrm{min} \times 59.6 \mathrm{hr} \times 60 \mathrm{~min} / \mathrm{hr}=107280$ milliliters

$11.77 \% \times 107280$ milliliters $=12,552 \mathrm{~g}$ of chlorides

Effluent:

\begin{tabular}{|c|c|c|c|}
\hline 940 Hot Zone $20.3 \mathrm{~g}$ & 940 Quench $23.9 \mathrm{~g}$ & 940 Cyclone $3.5 \mathrm{~g}$ & $\begin{array}{l}940 \text { Composite Rinse } \\
\text { unknown mass }\end{array}$ \\
\hline $\begin{array}{l}\text { Sodium } 59000 \mathrm{ppm} \\
(1.2 \text { grams })\end{array}$ & $\begin{array}{l}\text { Sodium } 76,000 \mathrm{ppm} \\
(1.82 \text { grams) }\end{array}$ & $\begin{array}{l}\text { Sodium } 2,200 \mathrm{ppm} \\
\text { (.01 grams) }\end{array}$ & \multirow{6}{*}{$\begin{array}{ll}\text { Sodium } & 4,000 \mathrm{ppm} \\
\text { Chloride } & 5200 \mathrm{ppm} \\
\text { Nickel } & 11,000 \mathrm{ppm} \\
\text { Cerium } & 160,000 \mathrm{ppm} \\
\text { Lead } & 10,000 \mathrm{ppm} \\
\text { Zinc } & 6,200 \mathrm{ppm}\end{array}$} \\
\hline $\begin{array}{l}\text { Chloride } 1900 \mathrm{ppm} \\
\text { (04 grams) }\end{array}$ & $\begin{array}{l}\text { Chloride } 14,000 \mathrm{ppm} \\
(.33 \text { grams) }\end{array}$ & $\begin{array}{l}\text { Chloride780 ppm } \\
(.002 \text { grams })\end{array}$ & \\
\hline $\begin{array}{l}\text { Nickel } 3000 \mathrm{ppm} \\
\text { (.06 grams) }\end{array}$ & $\begin{array}{l}\text { Nickel } 39,000 \mathrm{ppm} \\
\text { (. } 93 \text { grams) }\end{array}$ & $\begin{array}{l}\text { Nickel } 20,000 \mathrm{ppm} \\
\text { (.07 grams) }\end{array}$ & \\
\hline $\begin{array}{l}\text { Cerium } 310,000 \mathrm{ppm} \\
(6.29 \text { grams })\end{array}$ & $\begin{array}{l}\text { Cerium } 68,000 \mathrm{ppm} \\
\text { (1.63 grams) }\end{array}$ & $\begin{array}{l}\text { Cerium } 46,000 \mathrm{ppm} \\
\text { (.16 grams) }\end{array}$ & \\
\hline $\begin{array}{l}\text { Lead } 18,000 \mathrm{ppm} \\
(.37 \text { grams })\end{array}$ & $\begin{array}{l}\text { Lead } 25,000 \mathrm{ppm} \\
(.6 \text { grams) }\end{array}$ & $\begin{array}{l}\text { Lead } 270,000 \mathrm{ppm} \\
(.95 \text { grams })\end{array}$ & \\
\hline $\begin{array}{l}\text { Zinc } \quad 17,000 \mathrm{ppm} \\
(.35 \text { grams })\end{array}$ & $\begin{array}{l}\text { Zinc } \quad 19,000 \mathrm{ppm} \\
(.45 \text { grams })\end{array}$ & $\begin{array}{l}\text { Zinc } 12,000 \mathrm{ppm} \\
(.042 \text { grams })\end{array}$ & \\
\hline
\end{tabular}


Lockheed Idaho Technologies Co

FORM EGG-2631\#

(Rev. 01-92)

\section{Run 941-942}

This run is for $118 \mathrm{hrs}$

The feed consisted of the water/metal solution running at $80 \mathrm{cc} / \mathrm{min}$, and the TrimSol at 40 cc/min.

The metal solution consisted of:

$5400 \mathrm{ppm}$ of $\mathrm{CeCl}_{3}, 2200 \mathrm{ppm}$ of $\mathrm{ZnCl}_{2}$, and $2250 \mathrm{ppm}$ of $\mathrm{PbCl}_{2}$.

The water/metals solution created a total volume of:

$80 \mathrm{cc} / \mathrm{min} \times(118 \mathrm{hrs} \times 60 \mathrm{~min} / \mathrm{hr})=566.4$ liters

The TrimSol solution created a total volume of:

$40 \mathrm{cc} / \mathrm{min} \times(118 \mathrm{hr} \times 60 \mathrm{~min} / \mathrm{hr})=283.2$ liters

The chloride content of the feed stream is calculated below:

1) TrimSol $\left(30 \% \mathrm{C}_{20} \mathrm{H}_{37} \mathrm{Cl}_{5}\right)$

Carbon 12

Hydrogen 1

Chlorine 35.453

$\left(\mathrm{C}_{20} \mathrm{H}_{37} \mathrm{Cl}_{5}\right)=(12 \times 20)+37+(35.453 \times 5)=454.265$

Chloride $177.265 / 454.265=.39$

$.39 \times .3=11.77 \%$

$40 \mathrm{cc} / \mathrm{min} \times 118 \mathrm{hr} \times 60 \mathrm{~min} / \mathrm{hr}=283200$ milliliters

$11.77 \%$ chloride $\times 283200$ milliliters $=33,332.64$ grams of chlorides

2) $\mathrm{CeCl}_{3} 140.12+(35.453 \times 3)=246.479$

chloride $106.36 / 246.48=.43$

$.43 \times 5400 \mathrm{ppm}=2330 \mathrm{ppm}$

.002330 grams $/ \mathrm{ml} \times 566400=1319.7$ grams of chlorides

3) $\mathrm{PbCl}_{2} 207.19+(35.454 \times 2)=278.1$

chloride $70.91 / 278.1=.255$

$.255 \times 2250=573.69 \mathrm{ppm}$

.00057 grams $/ \mathrm{ml} \times 566400=322.85$ grams of chlorides

4) $\mathrm{ZnCl}_{2} 65.37+(35.454 \times 2)=136.278$

Chloride $70.91 / 136.278=.52$

$.52 \times 2200 \mathrm{ppm}=1144.73 \mathrm{ppm}$

$.0011 \mathrm{grams} / \mathrm{ml} \times 566400=623.04$ grams of chlorides

Total Chlorides:

$33,332.64+1319.7+322.85+623.04=35,598.24$ grams of chlorides

It is important to note that the metal solution contributed $6.36 \%$ of the chloride loading. The metals solution did not impact the chloride loading of the system.

The total volume of flow into the system was:

Trimsol

Water/metals

$283200 \mathrm{ml}$

Purge Lines

$566400 \mathrm{ml}$

Annulus

$1,628,400 \mathrm{ml}$

$2,124,000 \mathrm{ml}$ 
Lockheed Idaho Technologies Co

FORM EGG-2631\#

(Rev. 01-92)

Liquid Effluent:

Chloride $1300 \mathrm{ppm}$, Sulfate $230 \mathrm{ppm}$, Chromium 3.9 ppm, Iron $.36 \mathrm{ppm}$, Moly $1.5 \mathrm{ppm}$, Nickel 7.98 ppm, Potassium 38 ppm, Sodium 2000 ppm, Zinc 17 ppm

$1250 \mathrm{cc} / \mathrm{min} \times 59.6 \mathrm{hrs} \times 60 \mathrm{~min} / \mathrm{hr}=4,470$ liters

Chlorides: 5811 grams

Cerium : 8.08 grams $\quad 8.08 / \underline{643.68}=1.26 \%$

Zinc: .84 grams

$.84 / 236.02=.36 \%$

Lead 1.92 grams

$1.92 / 358.32=.54 \%$

Composite Rinse: 188 liters

Chloride $170 \mathrm{ppm}$, Sulfate $2300 \mathrm{ppm}$, Chromium $1.4 \mathrm{ppm}$, Iron $.38 \mathrm{ppm}$, Moly $1.5 \mathrm{ppm}$, Nickel 11.5 ppm, Potassium 140 ppm, Sodium 1400 ppm, Zinc 6.2 ppm 
(Rev. 01-92)

Total

$$
4,602,000 \mathrm{ml}
$$

The amount of chlorides entering the system was

$35,598.24 / 4,602,000 \mathrm{ml}=.0077 \mathrm{grams} / \mathrm{ml}=7,735 \mathrm{ppm}$ of chlorides

In Section 4 the steam was diluted at $350 \mathrm{cc} / \mathrm{min}$ or a total flow of $2,478,000 \mathrm{ml}$. This lowered the concentration of chlorides to:

$35,598.24 / 7,119648=5000 \mathrm{ppm}$ of chlorides.

The liquid effluent had a total flow of:

$1250 \mathrm{cc} / \mathrm{min} \times 118 \mathrm{hr} \times 60 \mathrm{~min} / \mathrm{hr}=8,850$ liter

The lab analysis showed a chloride concentration of $1800 \mathrm{ppm}$

$.0018 \times 8850000=15,930$ grams of chloride

The chlorides collected from the various solid samples (see Table 5) was only .3792 grams $15,930.4 / 35,598=.4475$ or $44.75 \%$ mass balance on the chlorides from the effluent. This does not account for the amount of chlorides recovered from the post test rinse or that remained settled in the feed tank as part of the surrogates.

The solids were collected from several locations in the system.( See diagram in Appendix C). The rod that held the metal coupons became a deposition surface within the casing. The mass balance for the metals used the following calculations:

1) Cerium calculation

Cerium 140.12

Chloride 35.453

$\mathrm{CeCl}_{3} 140.12+(35.453 \times 3)=246.479$

Cerium $140.12 / 246.479=.5679$

$.5679 \times 5400 \mathrm{ppm}=3067 \mathrm{ppm}$ cerium $=(.003 \times 566400)=1.699 .2$ grams of cerium

2) Zinc Calculation

Zinc 65.37

Chlorine 35.454

$\mathrm{ZCl}_{2}(65.37)+(35.454 \times 2)=136.28$

$65.37 / 136.28=.48$

$.48 \times 2850 \mathrm{ppm}=1367.1 \mathrm{ppm}$ of zinc $=(.0014 \times 566400)=774.32$ grams of zinc

3) Lead Calculation

Lead 207.19

Chiorine 35.453

$\mathrm{PbCl}_{2} 207.19+(35.454 \times 2)=278.1$

$207.19 / 278.1=.745$

$.745 \times 2250=1676.31 \mathrm{ppm}$ lead $=(00167 \times 566400)=945.89$ grams of lead

The metals mass balance takes into account the amount of surrogates that settled to the bottom of the tank, and the amount found in the post test rinses. The feed contained approximately: 1699 grams of cerium

774 grams of zinc 
Lockheed Idaho Technologies Co

FORM EGG-2631\#

(Rev. 01-92)

946 grams of lead

Lab analysis of the metal feeds indicates that only 4500 ppm of cerium instead of 5400,1230 ppm of lead instead of 2250, and $1840 \mathrm{ppm}$ of zinc instead of 2850 , actually went into the system as feed with the remainder left behind at the bottom of the tank. This results in the total metals in the feed as 1447 grams of cerium instead of 1699 grams, $\underline{519}$ grams of lead instead of 946 grams

and $\underline{500}$ grams of zinc instead of 774 grams.

The solids effluent from Table 5 gives the following results:

Cerium $\quad 156.86$ grams

Zinc $\quad 25.09$ grams

Lead $\quad 14.76$ grams

The liquid effluent from Table 6 gives the following results:

$\begin{array}{ll}\text { Cerium } & \text { ND } \\ \text { Zinc } & 150.45 \text { grams } \\ \text { Lead } & 2.56 \text { grams }\end{array}$

The post test rinses from Table 7 gives the following results:

Cerium 450 grams

Zinc $\quad 140$ grams

Lead 110 grams

The total cerium regained was 606.86 grams. This is $606.9 / 1447=42 \%$

The total zinc regained was 315.54 grams. This is $315 / 500=63 \%$

The total lead regained was 127.32 grams. This is $127 / 519=24.5 \%$

Observations:

The cerium deposits were seen primarily at the top of the rod, then the middle of the rod and then the titanium liner, with a small amount found in the cyclone, and none in the liquid effluent. It would appear that as soon as the surrogates mix with the oxidant the cerium begins depositing and probably coated most surfaces inside the casing. The recovery of cerium was $42 \%$ with most of that from the post test rinses. It can be assumed that the remaining cerium is on the ceramic rings. This resistance to rinsing illustrates the importance of controlling deposition on walls versus relying on post test rinsing to recover deposits. Further investigation is needed of the affect of cerium depositing on the ceramic rings. The SEM analysis shows the cerium showing up on the surface of the ceramic coatings but not being absorbed into the cracks of the coatings. The controlling mechanism for this behavior is not understood.

In the 120 hour run, there were 1447 grams of cerium fed into the system or approximately 12 grams/hour. The amount of cerium that would be captured in the brine of an ongoing system run is not known. A buildup of an actual radionuclide such as plutonium could occur on the scale of several grams/hr. The amount of deposition at the top of the reactor could become an operating constaint.

Deposits of lead were found further downstream than cerium on the titanium liner and in the cyclone. The rinsing process recovered most of the lead while relatively little was 
Lockheed Idaho Technologies Co

FORM EGG-2631\#

(Rev. 01-92)

found in the top or the middle rod deposits. A brine level in the reactor would most likely increase lead recovery.

The zinc had the highest recovery rate, appearing mostly in the cyclone and rinse processes.

Table 5: Solid Effluent

\begin{tabular}{|c|c|c|c|}
\hline $\begin{array}{l}942 \text { Top Rod } \\
70 \text { grams }\end{array}$ & $\begin{array}{l}942 \text { Mid Rod } \\
35 \text { grams }\end{array}$ & 942 Cyclone 16 grams & $\begin{array}{l}942 \text { Titanium Liner } \\
568 \text { grams }\end{array}$ \\
\hline 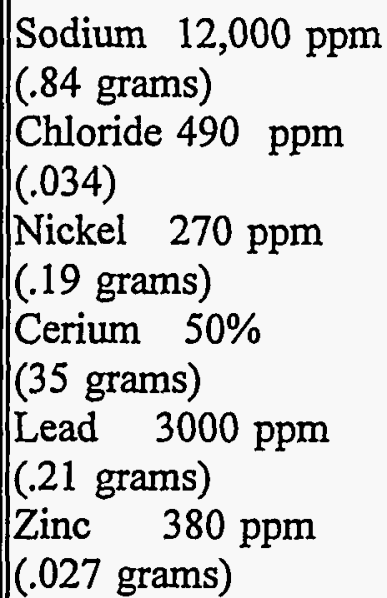 & $\begin{array}{l}\text { Sodium } 66,000 \mathrm{ppm} \\
(2.31 \text { grams }) \\
\text { Chloride } 480 \mathrm{ppm} \\
(.0168 \text { grams }) \\
\text { Nickel } 7400 \mathrm{ppm} \\
(.26 \text { grams }) \\
\text { Cerium } 36 \% \\
(12.6 \text { grams }) \\
\text { Lead } 14,000 \mathrm{ppm} \\
(.49 \text { grams }) \\
\text { Zinc } 430 \mathrm{ppm} \\
(.015 \text { grams) }\end{array}$ & $\begin{array}{l}\text { Sodium } 840 \mathrm{ppm} \\
(.0134 \text { grams }) \\
\text { Chloride } 2400 \mathrm{ppm} \\
(.038 \text { grams }) \\
\text { Nickel } 27000 \mathrm{ppm} \\
(.43 \text { grams }) \\
\text { Cerium } 8.4 \% \\
(1.34 \text { grams }) \\
\text { Lead } 27,000 \mathrm{ppm} \\
(.43 \text { grams }) \\
\text { Zinc } 110,000 \mathrm{ppm} \\
(1.76 \text { grams })\end{array}$ & $\begin{array}{l}\text { Sodium } 39000 \mathrm{ppm} \\
(22.15 \text { grams }) \\
\text { Chloride } 510 \mathrm{ppm} \\
(.29 \text { grams }) \\
\text { Nickel } 32000 \mathrm{ppm} \\
(18.18 \text { grams }) \\
\text { Cerium } 19 \% \\
(107.92 \text { grams }) \\
\text { Lead } 24,000 \mathrm{ppm} \\
(13.63 \text { grams }) \\
\text { Zinc } 41000 \mathrm{ppm} \\
\text { (23.29 grams) }\end{array}$ \\
\hline
\end{tabular}

Table 6:

\begin{tabular}{||l|l||}
\hline Liquid Effluent: & $1250 \mathrm{cc} / \mathrm{min} \times 118$ hours $\times 60 \mathrm{~min} / \mathrm{hr}=8850$ liters \\
\hline \hline Chloride & $1800 \mathrm{ppm}$ \\
\hline Sulfate & $300 \mathrm{ppm}$ \\
\hline Cerium & $\mathrm{ND}$ \\
\hline Chromium & $3.2 \mathrm{ppm}$ \\
\hline Iron & $.12 \mathrm{ppm}$ \\
\hline Lead & $.29 \mathrm{ppm}$ \\
\hline Moly & $.53 \mathrm{ppm}$ \\
\hline Nickel & $5.27 \mathrm{ppm}$ \\
\hline Potassium & $20 \mathrm{ppm}$ \\
\hline Sodium & $2500 \mathrm{ppm}$ \\
\hline Zinc & $17 \mathrm{ppm}$ \\
\hline
\end{tabular}


Lockheed Idaho Technologies Co

FORM EGG-2631\#

(Rev. 01-92)

Table 7: Post Test Rinses

\begin{tabular}{||l|l|l|l||}
\hline $\begin{array}{l}\text { Vessel/Brine Take Off } \\
(17 \text { liters })\end{array}$ & $\begin{array}{l}\text { Rinse \#1 } \\
(1517 \text { grams })\end{array}$ & $\begin{array}{l}\text { Rinse \#2 } \\
(2988 \mathrm{gr})\end{array}$ & $\begin{array}{l}\text { Supernatant } \\
(215 \text { liters })\end{array}$ \\
\hline 1 gram of cerium & 334 grams of cerium & 63 grams of cerium & 52 grams of cerium \\
\hline & 73 grams of lead & 36 grams of lead & 1 gram of lead \\
\hline & 15 grams of zinc & 78 grams of zinc & 47 grams of zinc \\
\hline
\end{tabular}




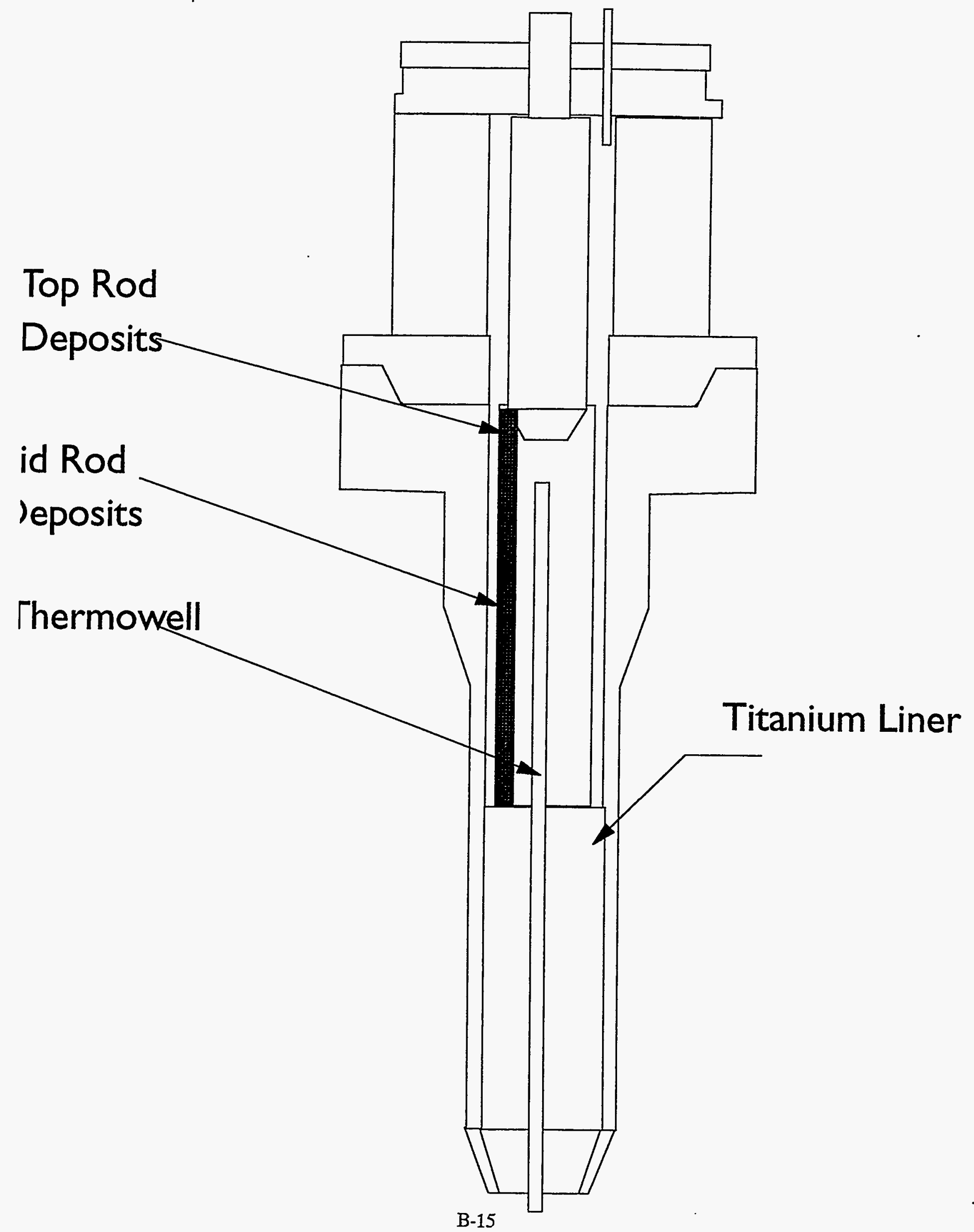




\section{Attachment 1}

\section{INEL Corrosion Test Plan}




\title{
INEL Corrosion Test Plan
}

\author{
G. T. Hong
}

Published March 1994

\author{
MODAR, Inc. \\ 14 Tech Circle \\ Natick, Massachusetts 01760
}

Prepared for EG\&G Idaho, Inc. and for the

U.S. Department of Energy

Assistant Secretary for Environmental Management

Under DOE Idaho Operations Offlce

Contract DE-AC07-76ID01570 


\section{INEL Corrosion Test Plan \\ EGG-WTD-11391}

Prepared by:

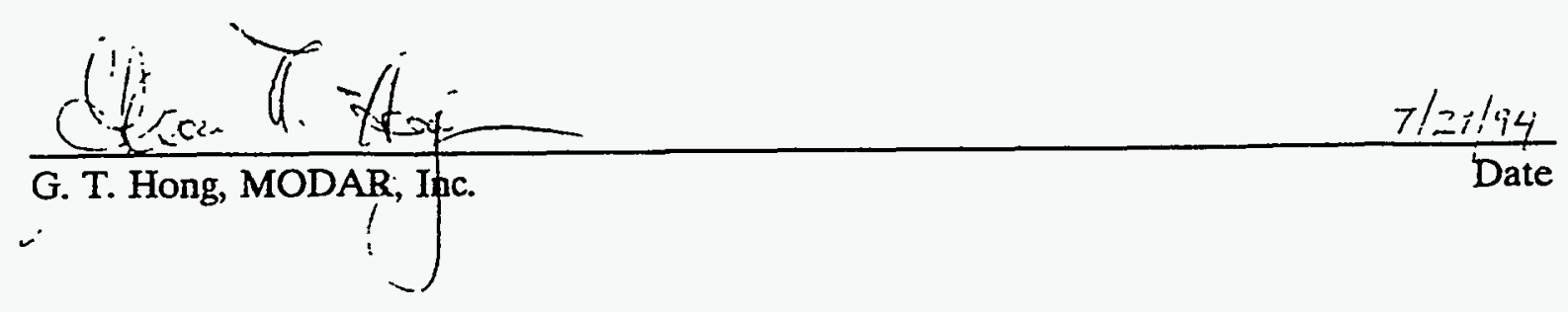

Reviewed by:

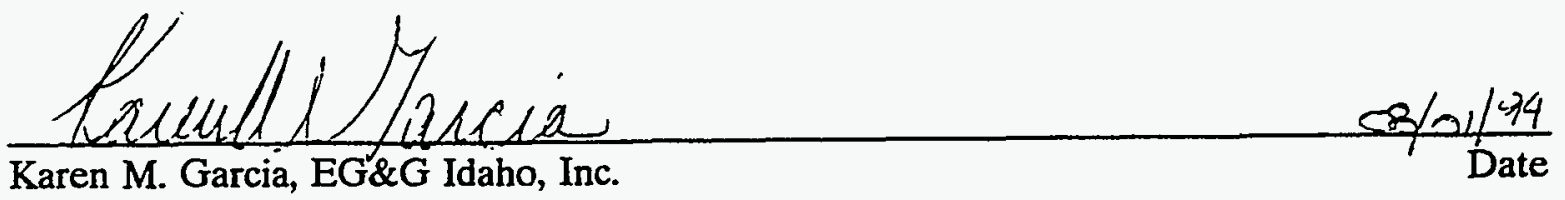

Approved by:

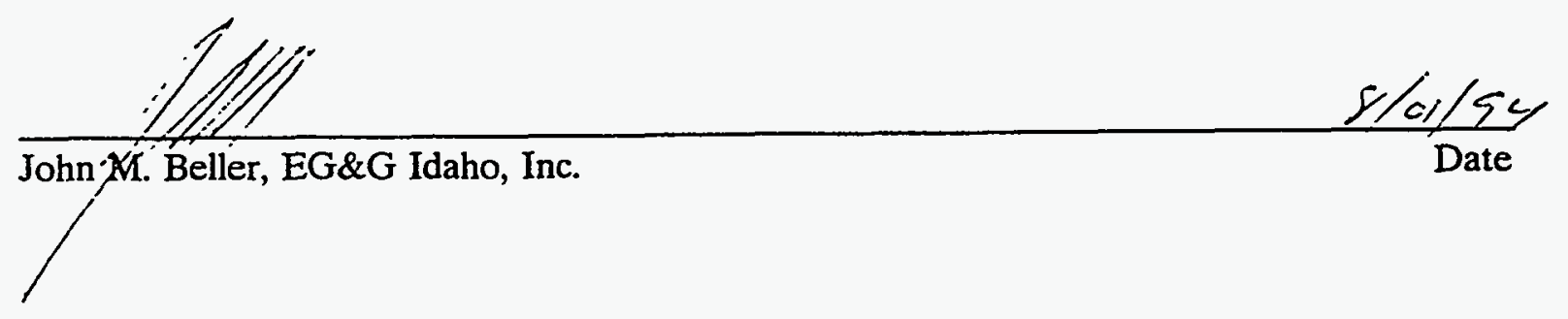




\begin{abstract}
The process of supercritical water oxidation creates a material challenge in several zones. Ceramics are known to have a high degree of corrosion resistance in many environments. This test will evaluate multilayered ceramics that have been applied by the thermal process. The ceramic will be sprayed to the inside of rings and exposed to the supercritical water oxidation environment.
\end{abstract}




\section{SUMMARY}

The goal of the test is to investigate and identify ceramic coatings for use in supercritical water oxidation (SCWO) environments. The test evaluates three coatings in two different SCWO environments.

The ceramic coatings have been applied to the internal diameter of rings using a thermal spray process. Several different layers are applied to accommodate the thermal expansion of the substrate at operating conditions. The rings will be evaluated in MODAR's SCWO reactor. TrimSol, water, and air will be introduced into the reactor at $3,400 \mathrm{psi}$ and $600^{\circ} \mathrm{C}$. The rings will be exposed to $600^{\circ} \mathrm{C}$ in the top zone of the reactor and $350^{\circ} \mathrm{C}$ at the bottom of the reactor.

The first test run will be 60 hours with five temperature cycles, the second test run will be for 60 hours with two temperature cycles, and the third test run will be for 120 hours with two temperature cycles. The rings in the center of the reactor could see up to 240 hours of testing. The rings will be visually inspected, then sectioned. Micrographic analysis will be used to define the mechanisms of corrosion and failure of the rings. 


\section{CONTENTS}

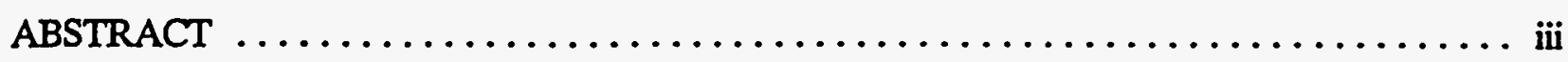

SUMMARY $\ldots \ldots \ldots \ldots \ldots \ldots \ldots \ldots \ldots \ldots \ldots \ldots \ldots \ldots \ldots \ldots \ldots \ldots \ldots \ldots \ldots$

1. GENERAL DESCRIPTION $\ldots \ldots \ldots \ldots \ldots \ldots \ldots \ldots \ldots \ldots \ldots \ldots \ldots \ldots \ldots \ldots$

2. SYSTEM CONFIGURATION $\ldots \ldots \ldots \ldots \ldots \ldots \ldots \ldots \ldots \ldots \ldots \ldots \ldots \ldots \ldots \ldots \ldots$

3. CORROSION SAMPLE RIG $\ldots \ldots \ldots \ldots \ldots \ldots \ldots \ldots \ldots \ldots \ldots \ldots \ldots \ldots \ldots \ldots$

4. TEST MATRIX AND SCHEDULE $\ldots \ldots \ldots \ldots \ldots \ldots \ldots \ldots \ldots \ldots \ldots \ldots$

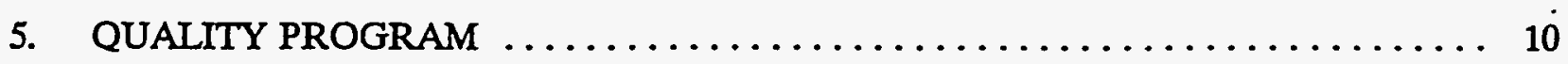

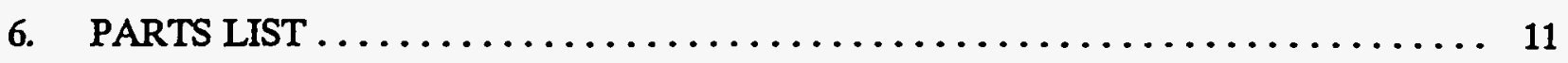

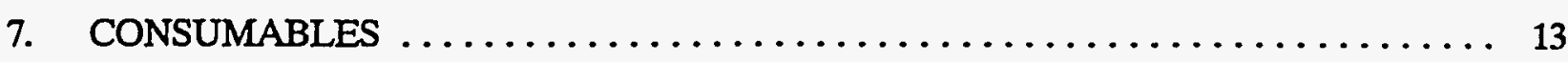

Appendix A-Statement of Work $\ldots \ldots \ldots \ldots \ldots \ldots \ldots \ldots \ldots \ldots \ldots \ldots \ldots \ldots \ldots \ldots \ldots \ldots \ldots$

\section{FIGURES}

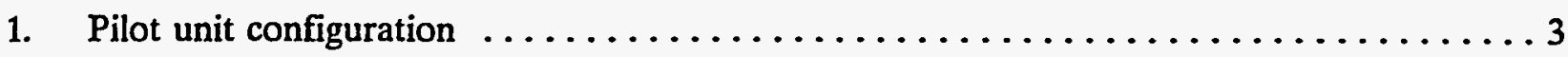

2. Corrosion sample cartridge $\ldots \ldots \ldots \ldots \ldots \ldots \ldots \ldots \ldots \ldots \ldots \ldots \ldots \ldots$

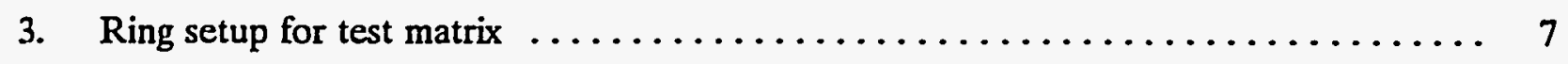

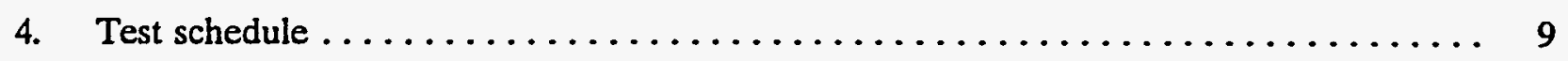

\section{TABLES}

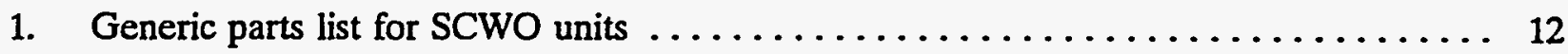

2. Generic consumables list for SCWO testing $\ldots \ldots \ldots \ldots \ldots \ldots \ldots \ldots \ldots \ldots \ldots \ldots \ldots$ 


\section{INEL Corrosion Test Plan}

\section{GENERAL DESCRIPTION}

The process of supercritical water oxidation (SCWO) engenders some extremely aggressive environments in the course of treating many wastes of interest. The difficult challenge presented to system materials of construction can sometimes be answered by noble metals such as gold and platinum; however, the high cost of these materials is likely to be prohibitive for most applications. Ceramics are known to have a high degree of corrosion resistance in many environments, are generally modest in cost, and are thus favored candidates for SCWO applications.

The goal of the current project is to investigate and hopefully identify suitable ceramic coatings for use in SCWO environments. The project entails moderate duration testing of three different thermal spray coatings in two different SCWO environments. The chemical composition of these environments is based on TrimSol cutting fluid, and has been described in the Statement of Work (Appendix A). The TrimSol will be diluted to provide a chloride level of at least $5,000 \mathrm{mg} / \mathrm{kg}$ on an aqueous basis in the SCWO environments. Neutralization will be carried out only after the process fluid has exited the test zones.

The primary purpose of ceramic coatings in SCWO systems is expected to be the protection of equipment surfaces exposed to the most demanding areas of the process environment. As such, cylinder inside diameters are the most important geometry, and given that the coatings are geometry sensitive, it is this configuration which has been chosen for testing. Furthermore, coating of cylinder inside diameters less than about 4 in. is difficult and would require additional developmental work. For these tests, a cylinder inside diameter of about 7 in. will be used, a size range that is within common practice and very relevant to pilot-scale reactor vessels. The tests will be carried out in MODAR's pilot-scale SCWO system. 


\section{SYSTEM CONFIGURATION}

The system configuration to be used for these tests is shown in Figure 1. One part of TrimSol at about $13 \mathrm{wt} \%$ in water is pumped up to system operating pressure of about $3,400 \mathrm{psi}$ and introduced to the reactor through a downward-pointing insulated nozzle. Air and an appropriate amount of water are pumped to pressure, heated to about $600^{\circ} \mathrm{C}$ with electrical radiant heaters in a "hot box," and introduced to the reactor through an annulus around the cool core feed stream. The two streams mix and reaction commences, achieving a final reaction temperature of about $600^{\circ} \mathrm{C}$. Acids and salts form within the reaction zone; some of the salts will adhere to the ceramic coated walls in the reaction zone. The reacted process stream continues in downflow until it enters the cooldown zone, which is maintained by a separate stream of cold water. The process stream continues along its downward path until it reaches the approximate location of the exit tube. At this point, the process stream mixes with cool dilute caustic and is neutralized. The warm mixed stream exits from the vessel and passes through a heat exchanger to be brought to near-ambient temperature. After two stages of insoluble solids removal, pressure is let down to about 1,500 psi and a liquid vapor separation carried out (V-491). The liquid and gas streams drawn off from the separation vessel are reduced to near ambient pressure and then vented, drained, and analyzed online or collected for analysis.

As shown in Figure 1, the reactor vessel possesses horizontal arms. These house either filtration or quenching apparatus for a reversing flow mode of operation, and will not be used in these tests. The axial temperature profile will be monitored by thermocouples located within the central thermowell. Temperature will be monitored at least four axial positions within the internal can. 


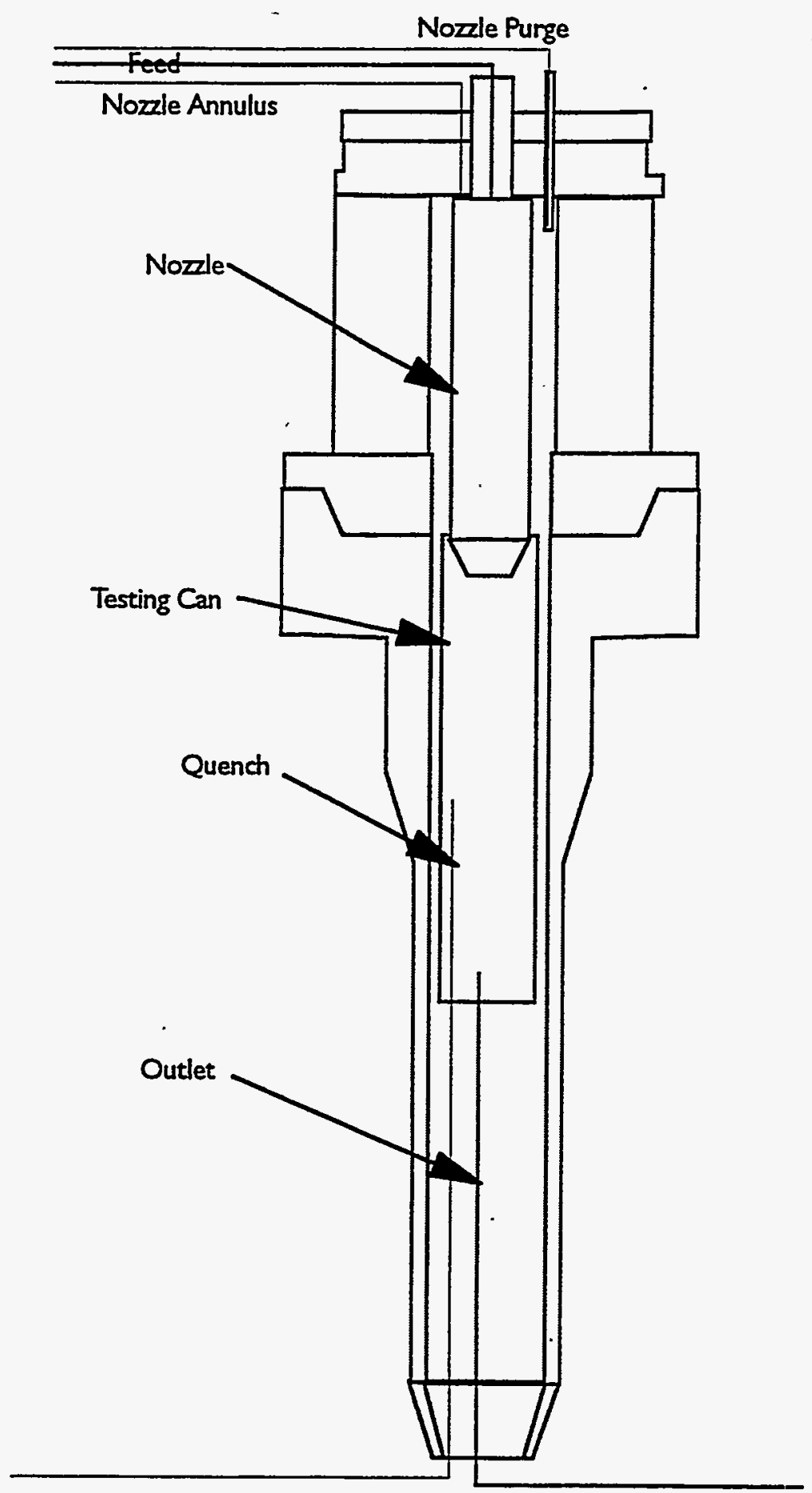

Figure 1. Pilot unit configuration. 


\section{CORROSION SAMPLE RIG}

The detailed setup to be used for the corrosion samples is shown in Figure 2. Fifteen coated rings, 3 in. high and about 7 in. ID after coating, will be stacked and potted with an inert mortar inside a 45 -in. high casing. The casing in turn will be mounted within the pilot plant vessel reactor. A cover plate is bolted onto the cylindrical casing and an Alloy 625 rod protrudes down into the stack of rings from its lower surface. A short length of threaded rod is welded onto the main rod at each ring position, allowing the mounting of 1 or 2 metallic corrosion coupons. These coupons will include at least one each of Alloys 625 and C276 in each zone to serve as reference materials, as these alloys have the largest exposure database available from prior studies.

It is believed that the internal can of Figure 2 will provide excellent protection for the reactor vessel walls. A major concern which remains, however, is the survivability of exposed metallic parts, in particular the feed nozzle, the cover plate, the thermowell, and the metallic coupon rack. It is conceivable that these pieces will have to be replaced regularly or, if possible, constructed of more durable materials. As such construction is difficult, it will not be attempted unless early experimental results indicate a need. One possibility is the use of platinum; however, even this metal has questionable survivability under the conditions specified. In their corrosion tests for ARPA, General Atomics found platinum unsuitable for unneutralized mustard agent, a chlorine and sulfur containing organic as is TrimSol. Platinum wires will be included in the test rig of Figure 2 to obtain information in this regard. 


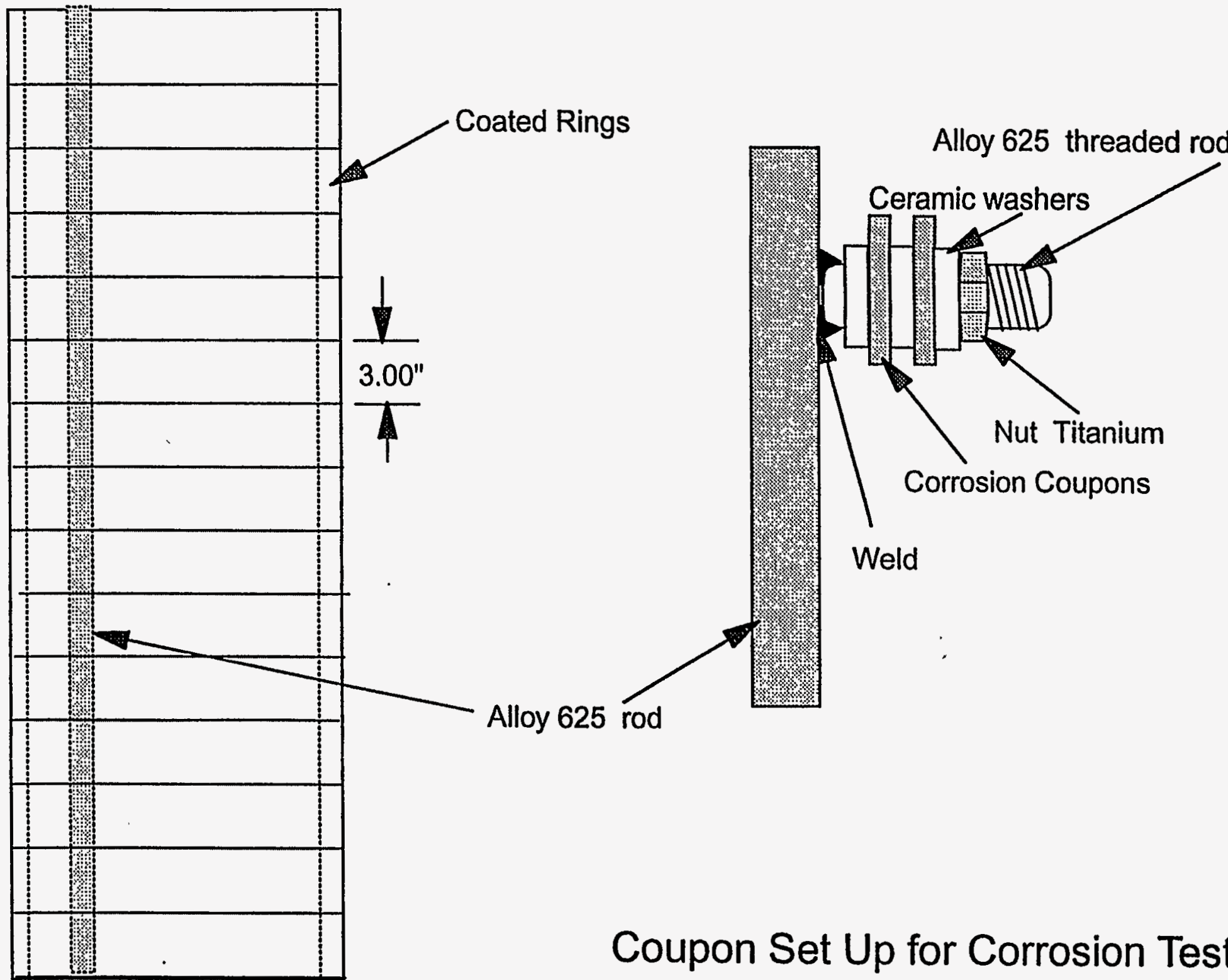

Flgure 2. Corrosion sample cartridge. 


\section{TEST MATRIX AND SCHEDULE}

A viable coating must be able to withstand extended periods at operating conditions as well as repetitive thermal cycling. For convenience, samples will be designated as hours/cycles/zone/set (e.g., the first set of samples seeing 60 hours of exposure and five thermal cycles in the reaction zone is designated as $60 / 5 / \mathrm{R} / 1$ ).

The coatings to be tested are two types of zirconia and one type of titania. The inert mortar is based on calcium sulfate.

The test matrix is comprised of four tests, as follows:

1. Baseline Test

The down flow mode of operation described in Section 2 has been previously used on the MODAR bench-scale system, but not on the pilot-scale system. The use of an internal "can" with perhaps excellent insulating properties is also a nonstandard arrangement. For these reasons, a baseline test will be required to establish appropriate flow rates for the various streams. The baseline test necessarily involves the full system setup including the corrosion rig, so that the corrosion samples in place will see noncorrosive SCWO exposure time. This time is not counted toward the exposure time with TrimSol feed running. Figure 3a shows the corrosion rings that will be in place for the baseline test as well as the 60-hour test that follows.

\section{60-Hour Test with Thermal Cycles}

Thermal cycling is of importance in materials testing because it involves stresses and environments which are different, and frequently more severe, than those encountered during steady state operation. For example, ceramic coatings may be most susceptible to delamination when subjected to the temperature gradients of a startup procedure. In this test, the 60-hour exposure time will be artificially interrupted five times, and reactor temperatures allowed to drop below $300^{\circ} \mathrm{C}$ or less. These thermal cycles will not all be evenly spaced because the first run segment will be terminated after about 4 hours to verify that the internal can is indeed protecting the pressure vessel from corrosive attack. Thus, after this first short segment, the reactor head will be removed, the internal can removed, and the equipment visually inspected for corrosion locales. Assuming the equipment is functioning as planned, the reactor will be reassembled and the test continued. Should the equipment not be functioning in the desired fashion, the possibilities for modification will be considered, and implemented if deemed practical. After 60 hours of exposure and five thermal cycles (with the possibility that some of these cycles will comprise full shutdowns with coating and reactor inspections), the reactor will be opened, the internal can removed, and the 60-hour samples removed from the casing. The corresponding metal coupons will also be removed. The rings and coupons will then be replaced with a second set of $60 / 5$ samples. It is unknown how difficult it will be to remove the potted rings from the inert mortar that backs them. In the extreme case, the casing cylinder will have to be cut up. A spare casing cylinder will be kept on hand to avoid schedule delays in this eventuality. 


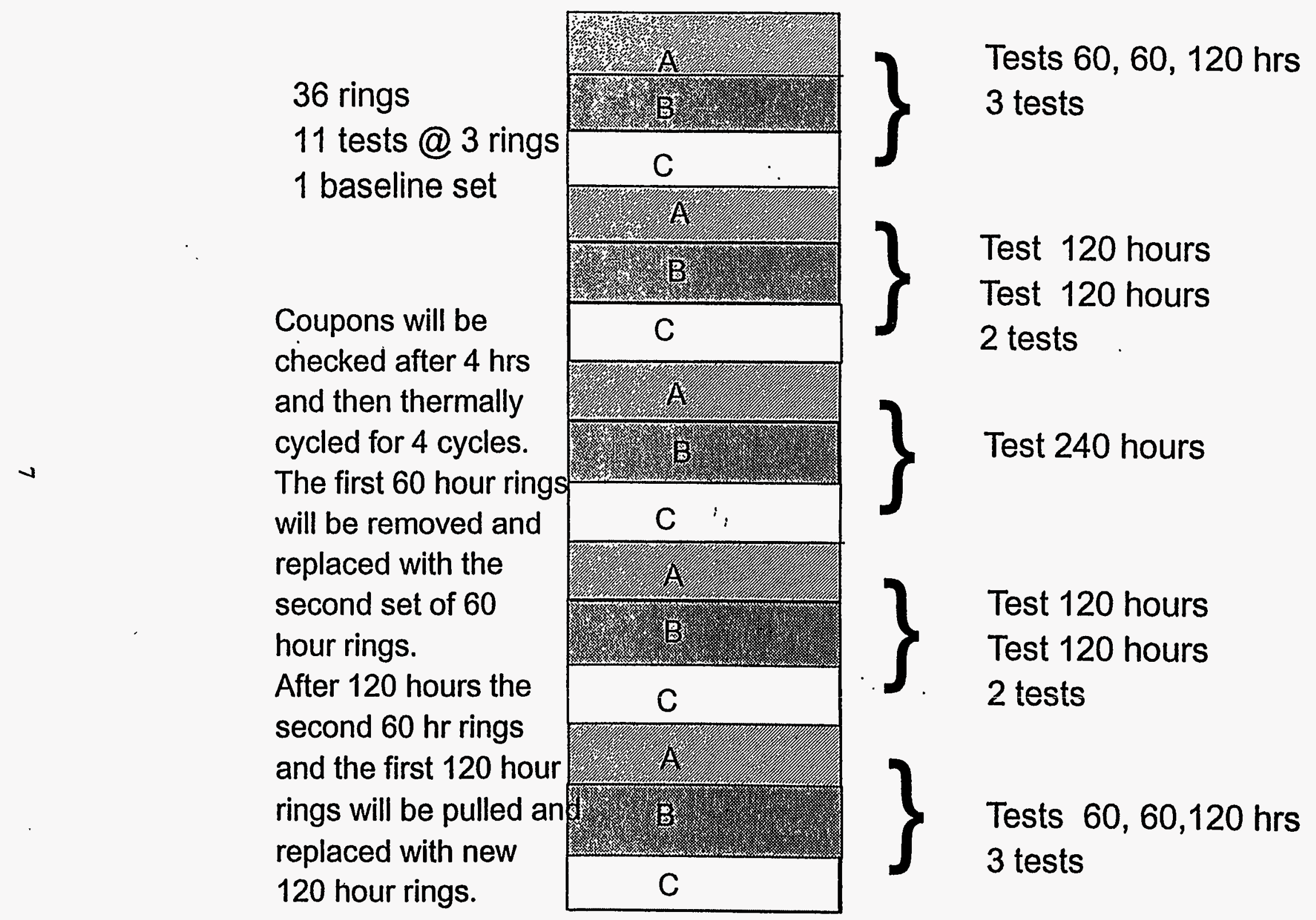

Figure 3. Ring setup for test matrix. 


\section{60-Hour Test with Thermal Cycles}

Figure $3 \mathrm{~b}$ shows the test rings as configured for this second 60 -hour test. This test should be similar to the first 60 -hour test, but with less of a need for full shutdowns because the viability of the setup will no longer be in question. Following this test, the second set of $60 / 5$ samples and the $120 / 10$ set of samples will be removed and replaced with two sets of $120 / 1$ samples.

\section{120-Hour Continuous Test}

Figure $3 \mathrm{c}$ shows the test rings as configured for this test. The duration of this test is nominal. Should it be found that budgetary limits are being approached, the time may be reduced. Likewise, should the project be proceeding smoothly, an extension of this run will be considered. This test involves only a single thermal cycle.

The test matrix described will require 36 coated rings as follows:

- Twelve $60 / 5$ rings

- Six $120 / 10$ rings

- Twelve 120/1 rings

- $\quad$ Three $240 / 11$ rings

- Three unused reference rings.

The scheme will allow duplicate comparisons to be made between two sets of 60/5 rings tested in different runs and two sets of 120/1 rings tested in the same run. The effect of thermal cycling can also be gauged by comparison of the 120/1 and 120/10 ring sets. It should be noted that the 240-hour exposure time is obtained by having a single set of rings which is in place for all of the tests $(60+60+120)$, as shown in Figure 3. The number of thermal cycles and exposure times provided for by this scheme are consistent with failure histories of similar ceramics previously tested at MODAR. In these previous tests, coatings have failed at exposure times between 100 and 200 hours.

Analytical procedures for the test project have been described in the proposal Description of Work. The analytical contract has not yet been assigned by EG\&G Idaho.

Figure 4 shows the prospective schedule for the test matrix. It should be emphasized that both the test matrix and schedule are success oriented, presuming for example that the samples and system will maintain their integrity for extended periods of time. The number and duration of tests, as well as the schedule and Test Plan, may have to be modified as events dictate. 


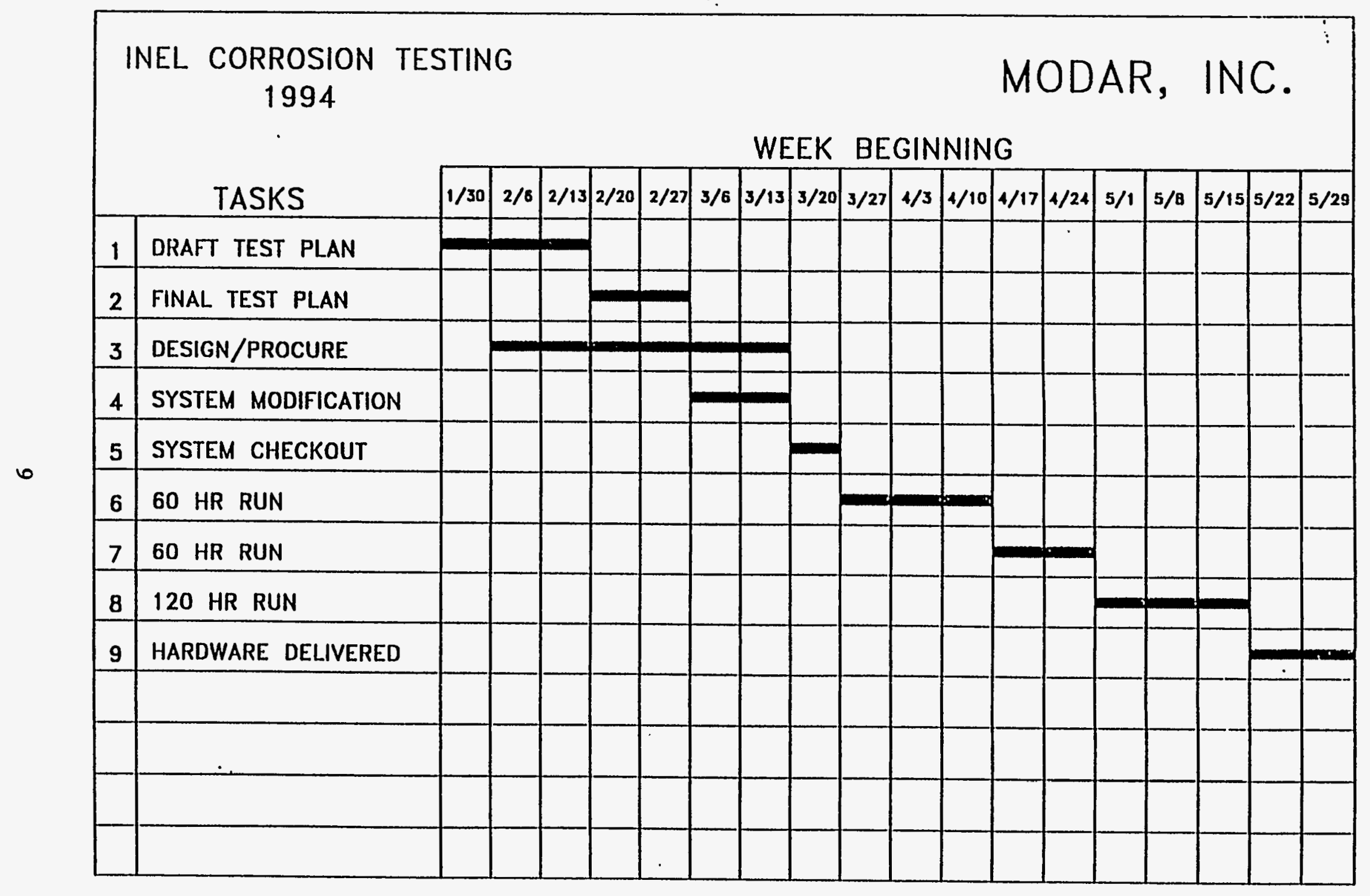

Figure 4. Test schedule. 


\section{QUALITY PROGRAM}

During the execution phase of the project, engineering and technical personnel will continually monitor progress and effectiveness so that any necessary cost saving adjustments can be made to optimize results. Engineering personnel will have the principal responsibility of ensuring the quality of all work performed. Management personnel will provide an appropriate level of independent verification. This verification will rely heavily on performance-based verification methods (as opposed to after-the-fact programmatic audit techniques). This will provide for real-time problem identification and resolution, as well as feedback to the planning process for quality improvement. Deficiencies noted will be reported to and resolved by engineering personnel.

Our approach to quality assurance results from our extensive experience in design, engineering, and construction of SCWO facilities, including three pilot plant configurations and numerous bench-scale projects. It is based on the recognition that quality achievement is the responsibility of those personnel performing work, that quality leads to improved productivity, and that appropriate verification of that quality is an important management tool in preventing and resolving problems, improving work product quality, enhancing performance, and satisfying contractual and regulatory requirements and commitments.

Specific responsibilities for this project are:

- Procurement

- Inspection, measuring, and testing equipment

- Document control

- Control of SCWO process

- Control of project nonconformances
Project Technical Director

Operations Supervisor

Project Technical Director

Project Engineer

Project Manager

As called for in the Scope of Work, our quality assurance and control procedures will be reviewed with and approved by EG\&G Idaho in the earliest phase of the contract. 


\section{PARTS LIST}

The following parts are specific to the current project:

- 2 casing cylinders.

- 1 casing cover plate

- 1 bolting ring

- 1 cover plate extension

- 1 raising/lowering cross piece

- 1 feed nozzle assembly

- 1 reactor thermowell assembly

- 6-ft threaded rod, $1 / 4-20$

- 50 ceramic shoulder washers

- 30 titanium nuts, $1 / 4-20$.

In addition, various nonspecific parts such as those listed in Table 1 will be required. No major equipment will be purchased. 
Table 1. Generic parts list for SCWO units.

Pipe, tubing, hose (not made of Inconel 625)

Includes C-276, C-22, 316 SS, 304 SS, plastic, rubber, PVC, CVPC, carbon steel, brass, copper

Valves (except those made of specialty alloys)

Manual, automatic with actuators, relief valves, vacuum breakers, valve trims

Maintenance parts, spare parts

Electrical equipment

Enclosures, wiring, contactors, circuit breakers, tie wraps, trays, conduit, junction boxes, fuse holders, fuses, relays, switches, heaters, heating tape, Variacs, terminals, transformers, cable, grounding equipment, lighting

Instrumentation (excluding computer control system)

Pressure-transducers, gauges, I/P converters

Temperature-thermocouples, thermowells, gauges

Level-differential pressure transducers, gauges

Flow-differential pressure transducers, dry test meter

Safety devices

Local temperature controllers

Local level controls

Insulation

Board, blanket, fiber, powder, molded forms for pipe, aluminum sheathing, tie wire

Structural support

Unistrut, angle iron, sheet, guard rails, hangers, clips, square tubing, I-beams, ladders, fittings, plate, walkways, stairs, scaffolding

Fittings

High pressure-_e.g., Autoclave Engineers)

Low pressure-Swagelok

Flanges

Seal rings

Miscellaneous items

Tools

Shielding (e.g., Lexan)

Floor drain covers 


\section{CONSUMABLES}

Typical consumables for SCWO testing are given in Table 2.

Table 2. Generic consumables list for SCWO testing.

Analytical consumables

Sample bottles or containers

Labels

Colorimetric gas analysis tubes

Tenax traps

$\mathrm{XAD}$ resin traps

TOCA reagents

Calibration gases

GC carrier gas

$\mathrm{pH}$ paper

Chloride strips

Gas absorption solutions

Gases for atomic absorption spectrophotometer

Chemicals for wet chemical analyses

Chemicals for ion specific electrode analyses

Carbon traps for vent gas

Ion exchange resins for feed water and effluent

Feed chemicals

Effluent/brine treatment chemicals

Neutralizing reagent (e.g., $\mathrm{NaOH}$ )

Welding consumables (e.g., wire, gases)

Propane for torch, fork truck

Filter elements

Computer consumables

Floppy disks

Printer paper

Printer ribbons

Modification materials

Repair materials

Batteries

Lubricants (for pumps, motors)

Joint sealants

Cleaning solutions

Paint, primer, brushes, rollers, thinner, sandblasting materials

Shipping materials

Thermocouple wire

Tool expendables (e.g., drill bits, saw blades) 


\section{Appendix A}

\section{Statement of Work}




\section{Appendix A \\ Statement of Work}

\section{Introduction}

Many of the Department of Energy (DOE) sites are generating and/or storing radionuclide contaminated hazardous wastes, i.e. mixed wastes, that are classified as Land Disposal Restricted (LDR) under the Resource Conservation and Recovery Act (RCRA). The Federal Facility Compliance Act of 1992 requires each facility at which the DOE generates or stores mixed waste to generate plans for treatment of all mixed wastes, or, for cases where no treatment technology currently exists, to generate plans for developing such technology. This act, which amends the RCRA, provides the impetus for accelerated efforts to develop, design, and construct facilities that will render DOE mixed wastes into forms that can be legally and inexpensively disposed of.

The Supercritical Water Oxidation (SCWO) technology holds promise of treating a portion of DOE mixed waste. The DOE strategy calls for demonstration of a mixed waste pilot plant designed for handling radioactive and hazardous waste. To support the design of this pilot plant, more data are required to solve the technical constraints of the process. One of these technical constraints is the selection of the materials of construction. Corrosion of SCWO reactors has been identified as a technical constraint to construction. This constraint can be eliminated by either preventing the corrosive elements of the waste stream from coming into contact with the materials of construction, or by identifying materials capable of withstanding the corrosivity of the fluid. Corrosion testing of various materials of construction is needed to identify materials capable of withstanding supercritical conditions.

\section{Purpose}

Specific testing will be conducted on a variety of coupons using selected waste streams. The coupons will be analyzed for types and amount of corrosion. A comparison will be made between the corrosion of the Hastelloy C-276, Inconel 625, other selected metals and ceramic lined coupons. The data from these tests will be used to conclude whether ceramic liners or other specialized metals are viable materials to be used in SCWO.

\section{Work Scope}

The contractor shall provide a system for demonstrating materials performance under the following conditions:

- $\quad 3,500 \mathrm{psi}$

- $\quad 100^{\circ} \mathrm{C}$ to $650^{\circ} \mathrm{C}$

- The ceramic coupons shall at least $2.7 \mathrm{in}$. in width, 0.125 in. thick, with 0.25 in. of clearance around the coupon. 
- The feed to be oxidized shall consist of TrimSol, a chlorinated cutting oil, and selected radionuclide surrogates (see Table 1) diluted to bring the chlorine content down to $5,000 \mathrm{ppm}$.

- Flow-through pressure vessel containing a coupon tree

- A test plan shall be written and submitted to EG\&G for approval prior to the start of testing. The contractor shall have a quality program that addresses procurement; responsibility and authority of inspection and test personnel; document control; inspection and testing; control of special processes; inspection, measuring and testing equipment; inspection and test status; and control of nonconformances.

- The design of the test setup shall be submitted to EG\&G for approval prior to the start of testing. The design package shall include detailed drawing of the location of the coupons in the system. It is assumed by EG\&G that the contractor has an existing system for SCWO and the design would involve modifying the existing system to accept the piping and pressure vessels needed for this particular test.

- Coupons shall be tested at the three significant temperatures of the process including the transition temperature as the process goes from the supercritical phase to the subcritical phase.

- The contractor shall propose the approach for mounting and retrieving the coupon tree. Each run shall go for at least 60 hours, with coupons removed at set intervals according to the test plan. Six to eight coupons will be placed in the pressure vessel for each run. Hastelloy C-276 and Inconel 625 coupons shall be included in each run as a reference.

- The ceramic coated and metal coupons shall be provided by EG\&G for the tests. All piping, pressure vessels, and valves exposed to the unneutralized waste stream at high temperatures and pressures shall be considered consumables for the test. The coupons and all hardware acquired for testing such as piping, pressure vessels, and valves shall be delivered to EG\&G for analysis.

- Solid, liquid, and gas effluent from each run shall be collected and analyzed for at least chrome, nickel, chloride, potassium, sodium, molybdenum, iron, sulphate, TOC, TOX, $\mathrm{pH}$, oxygen, carbon dioxide, methane, nitrogen, lead, cerium, and zinc. The lab analysis contract will be let by EG\&G under advisement from the contractor. 
Table 1. TrimSol with surrogates.

$\begin{array}{ll}\text { Chlorine } & 130,000 \mathrm{ppm} \\ \text { Sodium } & >700 \mathrm{ppm} \\ \text { Calcium, potassium } & >300 \mathrm{ppm} \text { each } \\ \text { Iron, titanium, zinc, lead } & >100 \mathrm{ppm} \text { each } \\ \text { Cerium } & 3,000 \mathrm{ppm} \\ \text { Total solids } & 25,000 \mathrm{ppm}\end{array}$

\section{Deliverables}

1. Draft Test Plan including experiment design, parts lists, consumables, and schedule

2. Final Approved Test Plan

3. All test logs and instrument readings

4. All coupons.

5. System hardware procured under contract

6. Effluent data.

\section{Schedule}

Draft Test Plan

Final Test Plan

Procurement

System assembled

System checkout

Testing complete

Hardware delivered
November 22, 1993

December 10, 1993

December 10, 1993

February 19, 1994

March 25, 1994

- July 29, 1994

August 26, 1994 